Dr. Adi Wijayanto, S.Or., S.Kom., M.Pd., AIFO, dkk.

还

\title{
Bunga Rampai
}

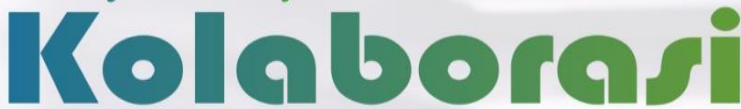

Multidisiplin Ilmu

dalam menghadapi Tantangan di Era New Normal

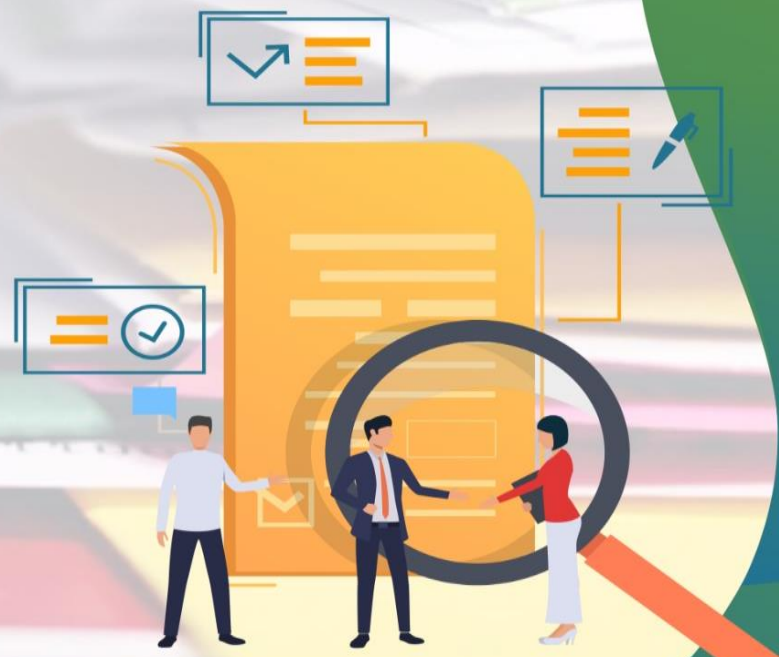

$\underbrace{-2}$

Editor:

Dr. Saidna Zulfiqar Bin Tahir, LC., M.Pd.

Dr. Andi Asrifan, S.Pd., M.Pd.

Yulianti, S.Sos., M.I.Kom.

Rifqi festiawan, S.Pd, M.Pd., AIFO

Pengantar:

Dr. Ir. Hetifah Sjaifudian, MPP. Wakil Ketua Komisi X, DPR RI 2019-2024 


\section{Bunga Rampai KOLABORASI}

\section{MULTIDISIPLIN ILMU}

\section{Dalam Menghadapi Tantangan}

\section{di Era New Normal}

Dr. Adi Wijayanto, S.Or., S.Kom., M.Pd., AIFO, dkk.

Editor:

Dr. Saidna Zulfiqar Bin Tahir, LC., M.Pd.

Dr. Andi Asrifan, S.Pd., M.Pd.

Yulianti, S.Sos., M.I.Kom.

Rifqi Festiawan, S.Pd., M.Pd., AIFO.

Pengantar:

Dr. Ir. Hetifah Sjaifudian, MPP.

Wakil Ketua Komisi X, DPR RI 2019 - 2024

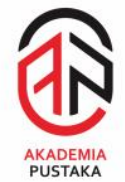




\section{BUNGA RAMPAI}

Kolaborasi Multidisiplin Ilmu Dalam Menghadapi Tantangan

di Era New Normal

Copyright (C) Adi Wijayanto, dkk. 2020

Hak cipta dilindungi undang-undang

All right reserved

Layout: Arif Riza

Desain cover: Diky M. Fauzi

Editor: Saidna Zulfiqar Bin Tahir, dkk

ix + 232 hlm: 14.8 x $21 \mathrm{~cm}$

Cetakan Pertama, Agustus 2020

ISBN: 978-623-6704-01-1

\section{Anggota IKAPI}

Hak cipta dilindungi undang-undang. Dilarang memplagiasi atau memperbanyak seluruh isi buku ini.

Diterbitkan oleh:

\section{Akademia Pustaka}

Perum. BMW Madani Kavling 16, Tulungagung

Telp: 081216178398

Email: redaksi.akademia.pustaka@gmail.com 
Sejak konfirmasi kasus pertama COVID-19 di Indonesia, berbagai sektor. Pertama, pandemi ini secara nyata mengguncang sektor kesehatan Indonesia. Kedua, COVID-19 juga membawa dampak pada pelemahan pertumbuhan ekonomi. Ketiga, berbagai adaptasi yang diperlukan untuk mengurangi jumlah COVID-19 juga menciptakan efek domino pada kehidupan sosial yang dampaknya menghantam seluruh elemen bangsa mulai dari rumah tangga hingga negara.

Di bidang pendidikan sendiri berbagai adaptasi telah dilakukan sebagai dampak adanya pandemi Covid-19. Salah satunya adalah melalui pembelajaran jarak jauh (PJJ). Dalam keberjalanannya, terdapat banyak aspirasi yang telah disampaikan berbagai pihak yang terdampak, baik itu guru, siswa, maupun orangtua murid. Dari banyaknya evaluasi yang masuk, keluhan yang dominan muncul adalah terkait minimnya akses terhadap internet, keterbatasan gawai, dan tingginya biaya kuota. Tentu saja menyelesaikan masalah ini tidak semudah membalikkan telapak tangan, dan pemerintah tidak dapat bergerak sendirian menghadirkan solusi dari beragam problema yang ada.

Tidak dapat dipungkiri bahwa COVID-19 membawa kita ke dalam era VUCA (volatility, uncertainty, complexity, ambiguity). VUCA adalah sebuah kondisi dimana terjadi perubahan cepat (Volatile) yang penuh ketidakpastian (Uncertainty), dengan segala permasalahan yang kompleks (Complexity), hingga pada akhirnya membuat semua pihak ragu mengambil keputusan (Ambiguity). Banyak riset menunjukkan bahwa kunci bertahan hidup dalam era VUCA ini adalah memiliki sikap adaptif dan kolaboratif. Setiap lapisan sosial, mulai dari 
individu hingga negara, harus dapat menyesuaikan diri terhadap perubahan serta mampu melibatkan kolaborasi berbagai sektor untuk mendapatkan solusi yang pendekatan berpusat pada manusia.

Salah satu kolaborasi yang memegang peranan penting dalam penanganan COVID-19 adalah antara pemerintah dengan para peneliti dan akademisi. Negara berbasis riset seperti Korea Selatan dan Jerman telah berhasil menunjukkan keunggulannya dalam menekan persebaran dan angka kematian akibat COVID19. Diantara langkah Korea Selatan dalam menekan COVID-19 adalah mengkombinasikan tes COVID-19 berskala besar, teknologi tracing, hingga transparansi dalam data dan kebijakan terhadap masyarakat. Di benua lainnya, Jerman juga berhasil menekan COVID-19 dengan melakukan tes masif. Kanselir Jerman Angela Merkel, yang memiliki gelar doktor di bidang kimia dan pernah bekerja sebagai peneliti, juga berhasil menyampaikan data yang akurat ke publik secara transparan, jelas, dan rutin.

Sebenarnya, Indonesia juga sudah mengatur kebijakan berdasarkan riset dan teknologi UU No.11 tahun 2019 tentang Sistem Ilmu Pengetahuan dan Teknologi. UU ini menyatakan dukungan negara terhadap penyelenggaraan ilmu pengetahuan dan teknologi sebagai landasan ilmiah dalam perumusan dan penetapan kebijakan pembangunan nasional. Akan tetapi, implementasi berbasis data dan penelitian dalam menentukan kebijakan, khususnya dalam kasus COVID-19, belum dapat dijalankan secara maksimal di Indonesia. Salah satu kendala yang nyata terjadi adalah data yang belum terintegrasi dari daerah maupun pusat.

Karenanya, bunga rampai "KOLABORASI MULTIDISIPLIN ILMU DALAM MENGHADAPI TANTANGAN DI ERA NEW NORMAL" yang berisi karya tulis ilmiah dari 28 peneliti ini merupakan suatu masukan yang sangat berharga bagi negara, 
khususnya pemerintah. Buku ini dibagi dalam tujuh bab yang diantaranya membedah kebijakan COVID-19 pada ranah pendidikan dan olahraga. Sebagai contoh, bunga rampai ini membahas kompetensi pendidik, tantangan belajar, serta merdeka belajar dalam masa new normal yang umumnya menuntut untuk dilaksanakan secara daring. Tidak ketinggalan, kumpulan karya tulis ini juga membahas bagaimana COVID-19 berdampak pada keilmuan berbasis riset serta dinamika multidisiplin ilmu. Selain skala nasional, beberapa dari karya tulis ilmiah dalam bunga rampai ini juga menggunakan studi kasus local, yang tentu saja data, analisa, serta kesimpulannya akan sangat bermanfaat bagi pemerintah daerah.

Akhir kata, semoga bunga rampai "KOLABORASI MULTIDISIPLIN ILMU DALAM MENGHADAPI TANTANGAN DI ERA NEW NORMAL" dapat menjadi salah satu inspirasi bagi akademisi dan peneliti lainnya untuk terus menyoroti dampak COVID-19 dan dinamika yang terjadi di lapangan. Semoga karya tulis ini dapat menjadi pemantik bagi para akademisi dan peneliti untuk menerbitkan publikasi yang sangat bermanfaat bagi masyarakat luas.

Dr. Ir. Hetifah Sjaifudian, MPP

Wakil Ketua Komisi X DPR RI

Agustus 2020 


\section{DAFTAR ISI}

KATA PENGANTAR ......................................................................................................ii

DAFTAR ISI.................................................................................................................

\section{BAB I BUDAYA KESEHATAN UNTUK MENJAGA IMUNITAS TUBUH}

Tantangan Dunia Pendidikan dalam Pembelajaran Budaya Kesehatan dan

Olahraga pada Masa New Normal

Dr. Adi Wijayanto, S.Or., S.Kom., M.Pd., AIFO - IAIN Tulungagung ............................... 1

Imunitas dan Pencegahan Di Era Pandemi

Ridwan Balatif, S.Ked. - Universitas Sumatera Utara

Strategi Pembelajaran Pendidikan Jasmani, Olahraga dan Kesehatan Guna Menjaga Imunitas Tubuh Siswa di Masa Pandemi Covid-19

Bakhrul Ulum, S.Or - SMKN 1 Bangil.

Nutrisi Dalam Meningkatkan Imunitas Tubuh Pada Masa Pandemi Covid-19

Nenni Dwi A.L, SP., MSi - Fakultas Kedokteran Universitas Sumatera Utara

\section{BAB II KESEHATAN MENTAL DAN EMOSIONAL DALAM PEMBELAJARAN}

Produktivitas Diri dan Kesehatan Mental di Era New Normal

Pasiska - STAI-Bumi Silampari Lubuklinggau

Upaya Guru Membentuk Karakter Sosial Siswa dalam Pembelajaran Daring di Masa Pandemi Covid-19

Nur Saadah - MAN 1 Grobogan

Kontribusi Kematangan Emosi Dan Optimisme Dalam Pembelajaran Di Era New Normal

Delsylia Tresnawaty Ufi, M.Si - Institut Agama Kristen Negeri Kupang

Peran Bimbingan Konseling (Bk) Dalam Pembelajaran Daring Di Tingkat

Madrasah Aliyah

Mita Mahda S., S.Ag - MA Hidayatul Athfal - Kota Pekalongan 55

\section{BAB III DINAMIKA IMPLEMENTASI PEMBELAJARAN DARING}

Dilema Perguruan Tinggi dalam Menerapkan Pembelajaran Daring di Masa Pandemi Covid-19

Suwantoro - Dosen Fakultas Tarbiyah IAIN Madura 
Dinamika Pendidikan \& Pengajaran di Era Pandemic Covid-19

Angga Putra, M.Pd - STIKIP YAPIS Dompu

Strategi Pembelajaran Online di Masa Pandemic

Nurhayati, M.Pd - STIES Baktiya Aceh Utara 79

Langkah Strategis Untuk Menunjangn Pembelajaran Daring Akibat Pandemi

Covid-19

Nur Wahyuni, M.Pd - STIKIP Yapis Dompu

\section{BAB IV MANAJEMEN DALAM MENGHADAPI TANTANGAN}

Panca Re-Si Manajemen Perubahan Strategi Baru di Era Normal Baru Aang Kunaifi, S.E., M.Ei - Institut Agama Islam Al-Khairat Pamekasan

Strategi Manajemen Dalam Menghadapi Perubahan dan Krisis di Masa

Pandemi

Dedeh Afifah, S.Pd., M.M., CSTMI - Universitas Islam 45

Urgensi Self Management dalam Menghadapi Goncangan Belajar di Era

Pandemi Covid-19

Sri Wahyuni, M.Pd - UNUSIA Jakarta

Menyiasati Keuangan Perusahaan Menghadapi Covid 19

Edwin Hatauruk, SE., MM.

\section{BAB V HIKMAH SPIRITUAL DIBALIK PANDEMI}

Mengurai Hikmah dibalik Wabah

Faliqul Isbah, M.Pd - IAIN Pekalongan

Reduksi Miskonsepsi Keimanan di Masa Pandemi Covid 19

Dr. Kurroti A'yun, S.T., M.Si - STIT-UW Jombang .

Manajemen Qolbu dalam Meningkatkan Kinerja di Tengah Wabah Dunia

Supriadi, MM - STAI Bumi Silampari Lubuklinggau Sumatera Selatan

Syukur dalam Masa Pandemi Covid-19

Aris Priyanto, M.Ag - IAIN Pekalongan

\section{BAB VI PERAN KELUARGA SEBAGAI ROLE MODEL}

Dampak Masa Pandemi Covid19 Terhadap Fungsi Keluarga Sebagai

Lembaga Pendidikan Informal

Azizah Husin - FKIP Unsri

Keluarga Sebagai Role Model Pelaksanaan Germas Di Era New Normal

Merita Eka Rahmuniyati, SKM., M.Gizi - Uiversitas Respati Yogyakarta .

Peran Keluarga Dalam Pendidikan Anak: Program Maghrib Mengaji Di Era

New Normal

Muhammad Al Mansur - STAIN Bengkalis. 


\section{BAB VII AKTIVITAS SELAMA PANDEMI}

Arti Penting Pembelajaran Kaligrafi Arab Untuk Menumbuhkan Kreativitas Seni Anak di Era Pandemi Covid-19

Nurul Huda, S.S., M.Pd.I - PBA FITK UIN Sunan Kalijaga Yogyakarta 190

Pembelajaran Matematika Berbasis Proyek dalam Meningkatkan Aktivitas Belajar di Tengah Pandemi Covid-19

Siti Rodi'ah, M.Pd.I - PRIMAGAMA Durenan.

Produktif Berkarya Di Era Pandemi

Nurul Nitasari, M.Pd - MTsN 1 Kudus

Berdamai Dengan Covid-19; Membiasakan Diri Dengan Tatanan Hidup Di Era Normal Baru

Diana Lutfiana Ulfa, M.Pd - IAIN Tulungagung 218

Strategi Pengelolaan Zakat Fitrah Pada Masa Pandemic Covid-19

Dian Adi Perdana, S.Sos.I., M.M - IAIN Sultan Amai Gorontalo 224 



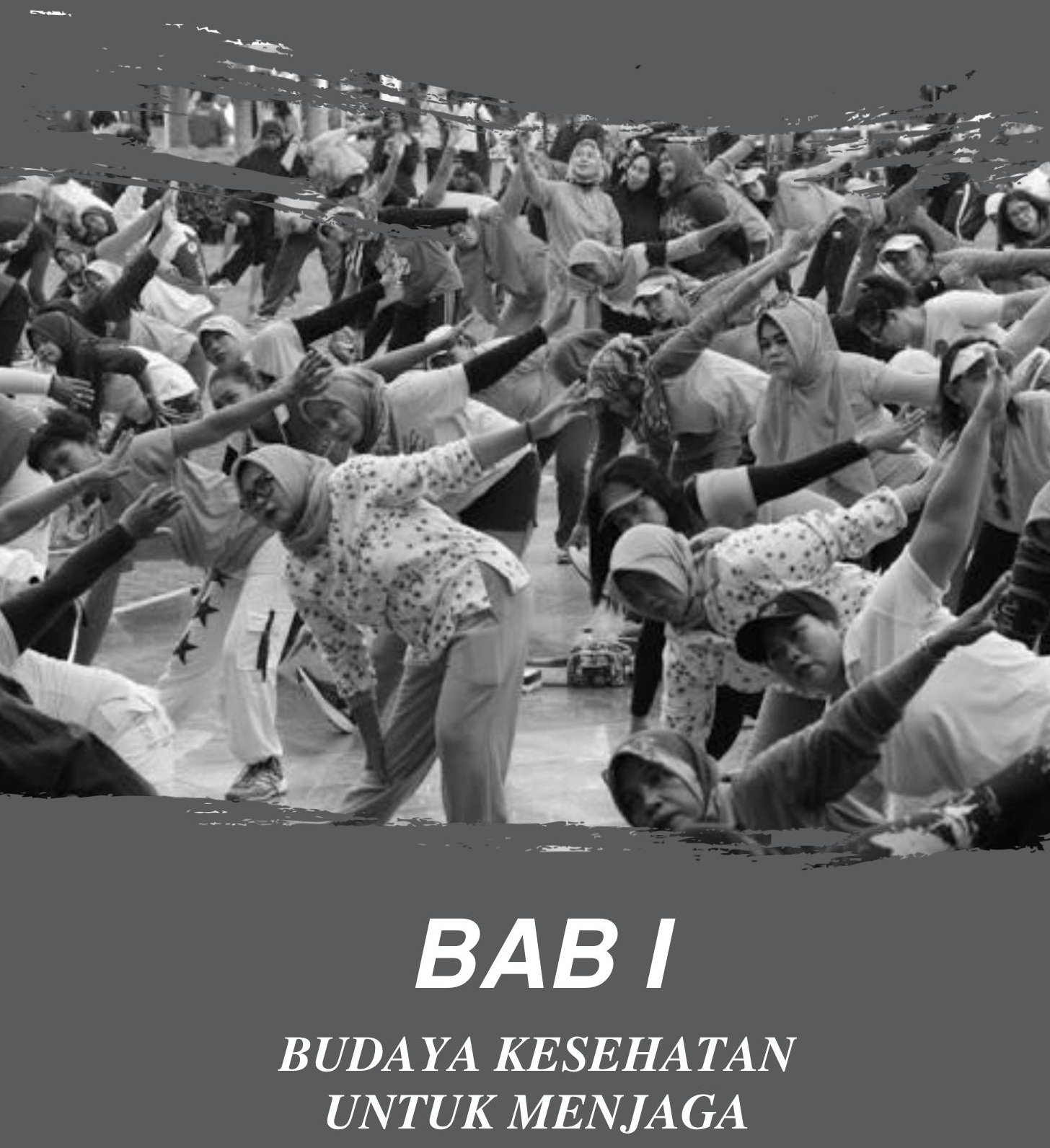





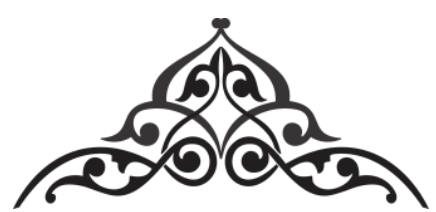

\title{
TANTANGAN DUNIA PENDIDIKAN DALAM PEMBELAJARAN BUDAYA KESEHATAN DAN OLAHRAGA PADA MASA NEW NORMAL
}

\author{
Dr. Adi Wijayanto, S.Or.,S.Kom.,M.Pd.,AIFO1 \\ IAIN Tulungagung
}

\begin{abstract}
"Budaya berolahraga yang dilakukan secara teratur dan sistematis dapat meningkatkan immunoglobulin

untuk meningkatkan imunitas tubuh agar dapat menurunkan resiko infeksi penyakityang disebabkan oleh virus"
\end{abstract}

erangan virus corona datang secara cepat dan dengan volume
yang besar menerjang seluruh belahan bumi, tidak terkecuali negara kita pada semua lini dan nyaris tidak pernah terprediksi sebelumnya. Pada tanggal 04 Juni 2020 sudah terkonfirmasi positif sebanyak 11.125.245 kasus dengan 528.204 jiwa melayang, sedangkan di Indonesia dengan waktu yang sama mencapai 62.142 terkonfimasi positif dan 3.089 meninggal dunia (WHO, 2020). Tindakan pencegahan secara universal sangat penting dilakukan untuk menekan jumlah penyebaran virus

${ }^{1}$ Adi Wijayanto lahir di malang 07 Oktober 1981, penulis merupakan Dosen IAIN Tulungagung dalam bidang ilmu Pembelajaran Olahraga dan Kesehatan, penulis menyelesaikan gelar Sarjana Ilmu Keolahragaan di Universitas Negeri Malang (2005), gelar Sarjana Teknik Informatika diselesaikan di STT Stikma Internasional Malang (2006), sedangkan gelar Magister Pendidikan diselesaikan di Universitas Negeri Jakarta Program Studi Pendidikan Olahraga (2009), dan akhirnya Doktor Ilmu Keolahragaan diselesaikan di Universitas Negeri Surabaya (2017). Gelar Profesi Ahli Ilmu Faal Olahraga diperoleh dari Perhimpunan Ahli Ilmu Faal Olahraga Indonesia (2019) yang tersertifikasi BNSP. 


\section{Tantangan Dunia Pendidikan dalam Pembelajaran Budaya...}

tersebut. Pemerintah sudah mengeluarkan beberapa aturan untuk menanggulangi virus corona dengan mengumumkan darurat kesehatan, aturan tersebut mulai dari Physical Distancing atau lebih dikenal dengan sebutan "jarak fisik" di masyarakat istilah menjaga jarak fisik lebih popular diistilahkan dengan "Jaga Jarak", pemakaian masker untuk menghindari percikan (droplet) cairan ludah dan ingus dari orang yang positif terinveksi corona, meningkatkan imunitas tubuh melalui makan makanan bergizi, berjemur untuk mendapatkan vitamin D dan berolahraga untuk meningkatkan kebugaran, hingga Lock Down dalam skala besar.

Serangan Corona Virus -19 yang tidak pernah menurun grafik penularan di Indonesia hingga saat ini, membuat kita berpikir ulang untuk melakukan New Normal demi keberlangsungan roda kehidupan ditengah virus yang terus menular. New normal ini diartikan sebagai langkah trobosan untuk mempercepat penanggulangan Covid-19 dalam aspek kesehatan dan social ekonomi dengan memperhatikan studi epidomologi dan kesiapan wilayah. Kesiapan masyarakat harus diperhatikan dengan kajian ilmiah agar new normal bisa berjalan dengan baik dan benar, tidak menuntut kemungkinan hal ini juga terjadi pada dunia pendidikan.

Kita sebagai pendidik harus menerapkan new normal ini dalam dunia belajar mengajar, sehingga ini menjadikan tantangan tersendiri bagi dunia Pendidikan, baik oleh pendidik, peserta didik, maupun stakeholder Pendidikan secara keseluruhan.

Teori sekuritisasi pendidik merupakan pilihan yang penting bagi pendidik untuk mengamati dan memahami fenomena darurat pembelajaran pada masa covid-19. Keamanan kesehatan baik pendidik dan peserta didik harus diprioritaskan, jangan sampai mereka terpapar virus tersebut yang berakibat fatal, dan yang paling bebahaya ketika pendidik maupun peserta didik

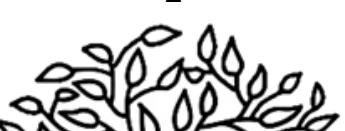


menjadi orang pembawa virus dan tidak ada gejala sama sekali. Sebab dengan seperti ini maka akan meningkatkan penyebaran virus terhadap semua orang khususnya keluarganya yang memiliki kondisi orang yang lemah seperti orang tua dan anakanak.

\section{Meningkatkan Imunitas Tubuh}

Pelaksanaan new normal yang menjadi tantangan dalam pendidikan salah satunya adalah menjaga kondisi pendidik dan peserta didik dalam keadaan sehat, bugar dan memiliki imunitas tubuh yang tinggi. Sistem imun adalah sistem kekebalan tubuh untuk melindungi tubuh kita dari benda asing seperti seperti bakteri kuman, bakteri, virus, racun dll. Sedangkan respon imun adalah respon atau tanggapan sistem tubuh kita terhadap benda asing, ada yang normal ada yang berlebihan dan sering diistilahan dengan auto imun. Tubuh kita memiliki sel yang dapat menjaga tubuh dari benda asing tersebut dan membunuhnya, sel tersebut sering diistilahkan sebagai antibodi. Imunitas yang terdapat pada tubuh, terdiri dari sistem imun spesifik (acquired adaptive immunity) atau kekebalan buatan dan sistem imun nonspesifik (innate immunity) atau kekebalan bawaan. Respons imun bawaan memainkan peran penting dalam protektif atau destruktif dan dapat membuka peluang bagi intervensi imun (Eakachai dkk. 2020: 5). Sistem imun spesifik muncul karena ada aktivitas pemicu spesifik. Imun spesifik akan membentuk antibodi dan limfosit. Antibodi dan limfosit akan diaktivasi apabila ada agen infeksi atau toxin yang masuk ke dalam tubuh. Aktivasi dilakukan untuk menyerang agen infeksi virus maupun menetralkan toksin tertentu, untuk mencapai kesembuhan. Kekebalan bawaan atau sistem imun nonspesifik (innate immunity) terjadi karena aktivasi umum, bukan berasal dari proses melawan agen penyakit.

Ada beberapa cara untuk meningkatkan sistem imunitas tubuh: 1) makan makanan bergizi, untuk bahan pembentukan sel

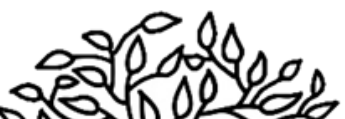




\section{*ै| Tantangan Dunia Pendidikan dalam Pembelajaran Budaya...}

antibodi, 2) tidur dan istirahat yang cukup, jika kita kurang tidur maka berdampak pada kekebalan tubuh kita akan menurun, sehingga beresiko terhadap serangan virus dan bakteri terhadap tubuh kita, 3) hindari stress, sebab dapat mengakibatkan kekacauan sistem hormonal, sistem syaraf, sistem penceranaan dan sistem lainnya, 4) Rutin Olahraga, dengan olahraga yang teratur yang disesuaikan dengan usia, fisik tubuh dan dengan aturan yang akan dijelaskan pada paragraph berikutnya, 5) Hindari Merokok dan alcohol, sebab dapat merusak paru dan menurunkan imunitas tubuh, 6) Bersihkan gigi, dengan membersihkan gigi, maka menghindari gigi rusak dan berlubang yang bisa menjadi sarang bakteri, 7) Konsumsi vitamin seperti vit. A, vit B-komplek dan Vit D.

Salah satu cara untuk meningkatkan imunitas tubuh adalah dengan berolahraga. Dengan berolahraga maka otak juga mengaktifkan sistem neuroendokrin untuk menghasilkan hormon adrenokortikotropik dari aksis hipotalamus-hipofisisadrenal dan korteks adrenal untuk melepaskan kortisol (Jee, 2020: 205). Perubahan hormon juga terjadi sebagai respons terhadap olahraga, termasuk peningkatan konsentrasi plasma dari beberapa hormon misalnya Epinefrin (adrenalin), kortisol, hormon pertumbuhan, dan prolaktin yang diketahui memiliki efek imunomodulator atau pengaruh imunitas tubuh.

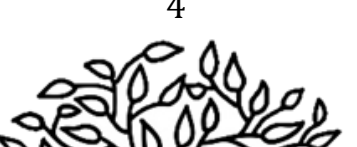




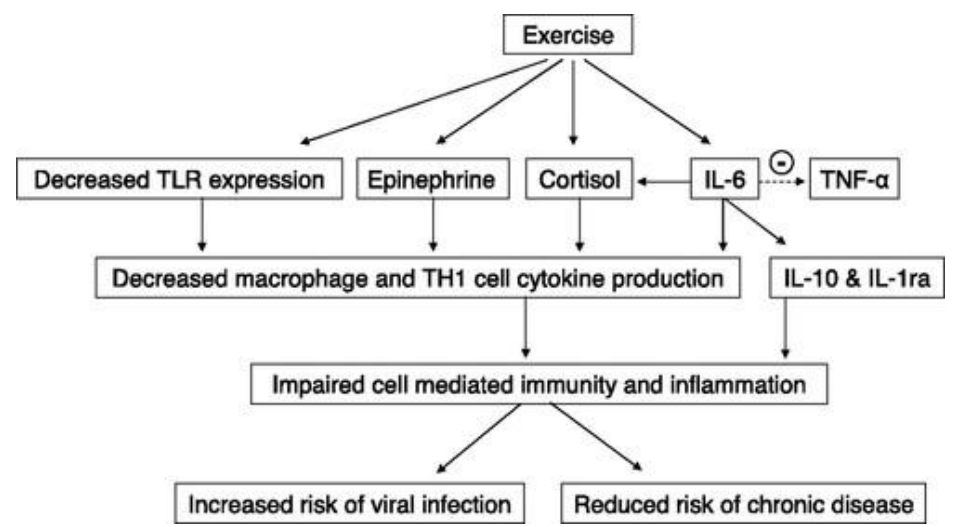

Gambar 1. Mekanisme latihan meningkatkan kerentanan terhadap infeksi (Gleeson, 2007: 695)

Olahraga yang teratur dan terukur dengan intensitas ringan dapat menurunkan resiko infeksi penyakit yang disebabkan oleh virus karena tubuh menghasilkan antibodi alami yang disebut dengan immunoglobulin. Olahraga yang dilaksanakan dengan intensitas ringan akan lebih bermanfaat terhadap imunitas tubuh dibanding tanpa melakukan aktivitas seperti duduk dan rebahan. Olahraga yang sesuai untuk dilaksanakan pada masa pandemic covid-19 ini agar imunitas meningkat dan kesehata tetap terjaga adalah olahraga yang dilakukan dengan menggunakan sistem energi aerobik. sistem energi aerobik merupakan olahraga yang membutuhkan oksigen banyak, dan dilakukan dengan intensitas ringan hingga intensitas sedang dengan tetap mengacu pada aturan-aturan pelatihan dasar yaitu Frekuensi, Intensitas, Type dan Time (FITT).

\section{Takaran Olahraga saat Pandemi Covid-19}

Daya tahan aerobik merupakan tingkat kebugaran pada kardiovaskular atau jantung paru, daya tahan aerobik sangat penting karena memengaruhi seberapa efisien tubuh dapat mengangkut oksigen ke tempat yang dibutuhkannya. Beberapa

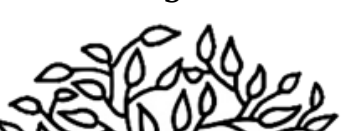




\section{| Tantangan Dunia Pendidikan dalam Pembelajaran Budaya...}

manfaat latihan olahraga melalui daya tahan aerobik, diantaranya adalah: 1) Latihan aerobik meningkatkan stamina, 2) tubuh menjadi lebih efisien dalam memindahkan oksigen ke dalam darah yang dapat digunakan oleh otot-otot, 3) badan akan merasa lebih energik, karena efisiensi ini berarti menggunakan lebih sedikit energi, 4) membantu mengontrol tekanan darah, 5) membantu mengatur gula darah, 6) dapat menurunkan kolesterol, mengurangi risiko penyakit kardiovaskular, 7) membantu membakar kalori ekstra untuk mempertahankan berat badan ideal, 8) meningkatkan imunitas tubuh atau meningkatkan antibodi tertentu dalam darah yang disebut immunoglobulin.

Immunoglobulin yang dapat mencegah virus dapat ditingkatkan dengan olahraga teratur dengan sistem energi aerobik. Banyaknya aktivitas olahraga atau sering diistilahkan frekuensi latihan sebaiknya dilakukan antara 3 hingga 5 kali dalam satu minggu yang dilakukan berselang atau jeda antara hari latihan yang satu dengan hari latihan yang lain, serta latihan tidak dilakukan tiap hari. Kegiatan tersebut harus dilakukan konsisten untuk mendapatkan adaptasi tubuh akibat latihan yaitu meningkatkan kebugaran dan daya tahan tubuh. Latihan tidak dilakukan tiap hari karena untuk tujuan pemulihan kondisi fisik atau sering diistilahkan dengan recovery. Tujuan recovery tersebut adalah memperbaiki sel-sel yang rusak selama berolahraga, mengembalikan sumber energi yang telah berkurang dan juga untuk merombak asam laktat menjadi energi kembali serta reoksigenasi myoglobin dan mengganti protein yang telah dipakai. Perlu kita ketahui bahwa asam laktat merupakan residu dari pembakaran energi selama berolahraga. Olahraga dengan sistem energi aerobik merupakan aktivitas yang banyak membutuhkan oksigen dalam proses pembakaran sumber energi yang berasala dari karbohidrat, protein dan lemak yang tersimpan didalam jaringan adipose (adipose tissue)

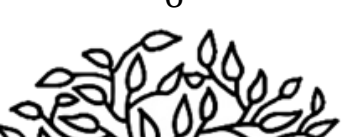


dan didalam sel-sel otot (intramuscular triglycerides) untuk menjadi ATP (Wijayanto, 2018 :28).

Intensitas olahraga dengan sistem energi aerobik dengan menggunakan intensitas rendah dan sedang, ukuran intensitas tersebut dapat dilakukan dengan memperhatikan usia dari individu yang melakukan olahraga tersebut, sebagai rumus adalah dengan memonitor denyut jantung sebagai cara tidak langsung untuk menafsir oksigen yang digunakan oleh tubuh selama Latihan maupun saat istrirahat. Denyut nadi maksimal adalah 220 - usia, sehingga itensitas Latihan yang dilakukan adalah $60 \%$ dari denyut nadi maksimal. Sebagai contoh usia anda adalah 40 tahun, maka denyut nadi maksimal adalah 22040 hasilnya adalah 180 kali dalam satu menit, sehingga denyut nadi Latihan olahraga dengan sistem energi aerobik yang dilakukan kurang lebih 180 x 60\%, maka denyut nadi Latihan adalah 108 kali dalam satu menit.

Waktu latihan atau aktivitas berolahraga sebaiknya dilakukan pada pagi hari, dimana saat pagi hari kadar oksigen tinggi dengan kadar polusi yang masih rendah. Dengan melakukan olahraga pagi hari maka hemoglobin yang mengikat oksigen lebih banyak, sehingga sangat efektif dalam suplai oksigen yang dikirim ke otot dan jaringan untuk pembakaran energi guna terbentuknya sliding filamen dalam kontraksi otot dalam bergerak. Durasi waktu untuk olahraga dengan sistim energi aerobik minimal 40 menit untuk mendapatkan adaptasi latihan yang bagus agar mendapatkan hasil latihan yang sesuai dengan yang diinginkan serta terjadi pembakaran lemak yang disimpan di adiposa. Jika kurang dari 40 menit maka yang terjadi latihan tidak mendapatkan hasil karena adaptasi latihan tidak terjadi, justru terjadi sistem energi anaerobik dengan cara pembakaran glikogen darah dan glikogen otot.

Jenis atau tipe olahraga aerobik tersebut yang dilakukan dengan intensitas rendah, menjadikan tidak ada tekanan otot

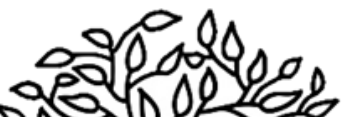




\section{" | Tantangan Dunia Pendidikan dalam Pembelajaran Budaya...}

yang berlebih, sehingga tubuh tidak mengalami stress, sehingga hormone endofrin akan dieksresikan dimana hormon tersebut merupakan senyawa kimia dalam tubuh untuk mengendalikan stress dan ketegangan, sehingga dengan meningkatnya hormon endofrin maka akan meningkat pula rasa gembira dalam hati, dan ini menjadikan hormon tersebut sebagai hormon kebahagiaan. Ketika stress menurun maka otomatis imunitas tubuh kita meningkat, dengan meningkatnya imunitas tersebut diharapkan dapat menangkal penyakit dalam bentuk virus maupun bakteri, terlebih lagi pada saat ini kita mengalami serangan pandemic virus corona secara global. Jenis olahraga aerobik yang sesuai saat pandemic covid antaranya jalan santai, lari santai, bersepeda santai, naik turun bangku, senam, loncatloncat dan lain sebagainya yang dilakukan dengan tetap memperhatikan protokol kesehatan.

Budaya berolahraga yang dilakukan secara teratur dan sistematis dapat meningkatkan kemampuan fisiologis organ tubuh 25\% lebih tinggi dibanding dengan orang yang tidak aktif. Kemampuan fisiologis semasa pandemi corona virus ini harus tetap terjaga agar virus dapat dihadang oleh antibodi kita sendiri, sehingga virus dapat dihancurkan dalam tubuh dan tidak berlembang biak yang dapat berakibat pada kerusakan jaringan tubuh yang dapat berakibat fatal hingga kematian.

\section{DAFTAR PUSTAKA}

Eakachai, Prompetchara., Ketloy, Chutitorn and Palaga, Tanapat. 2020. Immune responses in COVID-19 and potential vaccines: Lessons learned from SARS and MERS epidemic. Asian Pacific Journal of Allergy and Immunology. Vol. 38:1-9. DOI 10.12932/AP-200220-0772

Gleeson, Michael. 2007. Immune function in sport and exercise. Journal Appl Physiology. Vol 103: 693-699, 2007. doi:10.1152/japplphysiol.00008.2007

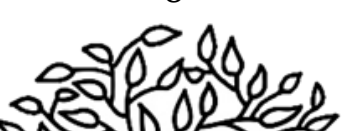


Jee, Yong-Seok. 2020. Influences of acute and/or chronic exercise on human immunity: third series of scientific evidence. Journal of Exercise Rehabilitation. Vol. 16(3):205-206. https://doi.org/10.12965/jer.2040414.207

WHO. 2020. WHO Coronavirus Disease (COVID-19) Dashboard. https://covid19.who.int/

Wijayanto, Adi. 2018. Pengaruh Latihan Renang Teratur dan Latihan Renang Tidak Teratur Terhadap Kadar Trigliserida Plasma pada Rattus Norvegicus. BIOTROPIC The Journal of Tropical Biology. Vol 2. No 1. Februari 2018 ISSN 25805029. 
| Tantangan Dunia Pendidikan dalam Pembelajaran Budaya...

10 


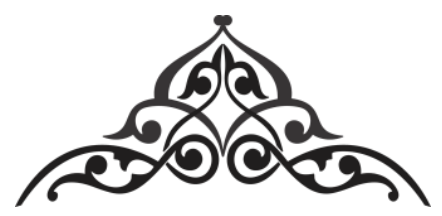

\title{
IMUNITAS DAN PENCEGAHAN DI ERA PANDEMI
}

\author{
Ridwan Balatif, S.Ked.² \\ Universitas Sumatera Utara
}

"Setiap orang dapat melaksanakan berbagai tindakan pencegahan dan pola hidup sehat untuk melindungi diri sendiri dan orang lain, terutama yang memiliki imunitas yang lemah atau penyakit penyerta (komorbid)"

Denyakit Coronavirus Disease 2019 (COVID-19) merupakan
pandemi yang menimbulkan masalah besar di seluruh dunia. Penyakit ini disebabkan oleh infeksi virus Severe Acute Respiratory Syndrome - Coronavirus - 2 (SARS-CoV-2). Virus ini menyerang sel alveolar di paru dan enterosit dikarenakan sel-sel tersebut memiliki Angiotensin Converting Enzyme 2 (ACE2) yang merupakan reseptor untuk virus SARS-CoV-2. Reseptor ini juga digunakan oleh virus SARS yang pernah menyerang negara China di tahun 2002-2003 (Zheng, 2020).

Dalam menghadapi berbagai agen infeksius seperti bakteri, virus, jamur, dan parasit, imunitas memegang peranan vital dalam melawan agen infeksius tersebut. Imunitas memiliki arti

2 Ridwan Balatif lahir di Kota Medan, Sumatera Utara pada tanggal 25 Maret 1998. Penulis merupakan mahasiswa jurusan Kedokteran di Universitas Sumatera Utara. Pada tahun 2020, penulis memperoleh gelar Sarjana Kedokteran di Universitas Sumatera Utara. 


\section{Imunitas dan Pencegahan di Era Pandemi}

sebagai suatu bentuk ketahanan tubuh terhadap suatu penyakit terutama infeksi. Dalam melaksanakan fungsi imunitas ini diperlukan gabungan kerjasama oleh berbagai sel, jaringan serta molekul yang gabungan tersebut disebut sistem imun. Apabila tubuh menghadapi suatu agen infeksius, berbagai sel dan molekul imun akan saling bekerjasama menimbulkan suatu reaksi untuk mengeliminasi agen tersebut, reaksi ini disebut respon imun (Bratawidjaja, 2018).

Sistem imun terbagi atas dua yaitu sistem imun bawaan (innate) dan didapat (adaptive). Disebut sistem imun bawaan dikarenakan telah ada serta siap berfungsi sejak lahir dalam menghadapi semua agen infeksius yang masuk kedalam tubuh (nonspesifik). Berbeda dengan sistem imun didapat yang harus mengenal terlebih dahulu agen infeksius yang menyerang tubuh sehingga apabila tubuh diserang agen yang sama untuk kedua kalinya, respon dari sistem imun didapat akan lebih cepat untuk membunuh agen tersebut (spesifik) (Bratawidjaja, 2018).

Sistem imun bawaan terdiri dari pertahanan fisik/mekanik (seperti kulit, selaput lendir, silia, batuk dan bersin), biokimia (seperti lisozim pada air mata, $\mathrm{pH}$ asam dari keringat, asam hidroklorida pada lambung), humoral (seperti komplemen, peptida antimikroba), dan seluler (seperti sel mast, fagosit, eosinofil, neutrofil, monosit, sel natural killer). Untuk sistem imun didapat terdiri atas sistem imun humoral (seperti sel B) dan seluler (seperti limfosit T) (Bratawidjaja, 2020). Dalam mengatasi berbagai agen infeksius seperti virus, sistem imun bawaan dan didapat akan saling bekerjasama.

Saat ini pemahaman respon imun dalam menghadapi infeksi virus SARS-CoV-2 masih terbatas. Namun dikarenakan virus SARS-CoV-2 memiliki kemiripan dengan virus SARS-CoV sebelumnya, ada kemungkinan respon imun yang dihasilkan oleh kedua virus hampir sama. Sehingga dalam mempelajari dan memahami respon imun terhadap virus korona dapat dipelajari

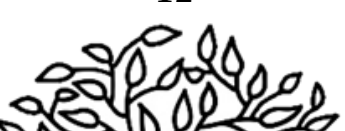


dari virus SARS-CoV. Ketika virus (antigen) masuk kedalam sel targetnya, antigen ini akan di presentasikan oleh Antigen Presenting Cells (APC). Antigen yang dipresentasi ini akan ditampilkan di permukaan sel oleh Major Histocompability Complex (MHC) kelas I agar dapat dikenali oleh sel T sitotoksik. Presentasi antigen virus SARS-CoV ini utamanya bergantung dari MHC kelas I dan MHC kelas II juga berkontribusi dalam proses presentasi ini (Li, 2020).

Presentasi antigen akan menstimulasi respon imun humoral dan selular seperti sel B dan sel T. Sama halnya dengan infeksi akut oleh virus, infeksi SARS-CoV juga memicu pembentukan antibodi IgM dan IgG dari respon imun humoral. Antibodi IgM yang spesifik SARS-CoV akan menghilang pada akhir minggu ke-12 dan antibodi IgG akan bertahan dalam waktu yang lebih lama (Li, 2020). Untuk menghindari respon imun tubuh, virus SARS-CoV-2 dapat menginfeksi sel makrofag (monosit), walaupun infeksi sel imun oleh virus korona jarang terjadi dikarenakan jumlah reseptor ACE2 yang sangat sedikit pada sel-sel imun. Produksi Interferon (IFN) tipe 1 akan terhambat akibat dari makrofag yang terinfeksi virus. Hal ini berakibat meningkatkan produksi mediator pro-inflamasi seperti IL-1, IL-6 dan TNF- $\alpha$ yang berkontribusi terjadinya cytokine storm (Felsenstein, 2020).

Timbulnya cytokine storm ini dapat menimbulkan kegagalan multi-organ dan Acute Respiratory Distress Syndrome (ARDS). Kedua kondisi sering menyebabkan kematian pada pasien COVID-19 (Ye, 2020). Seseorang dengan kondisi imunosupresif (sistem imun lemah seperti pada kanker, penggunaan kemoterapi, infeksi HIV, penggunaan kortikosteroid jangka panjang) lebih rentan untuk terinfeksi virus SARS-CoV dan memiliki prognosis yang lebih buruk (Liang, 2020; CDC, 2020).

Baik pada seseorang dengan kondisi imunitas yang baik maupun lemah haruslah selalu melaksanakan berbagai tindakan

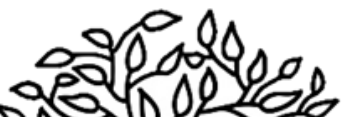




\section{1\% | Imunitas dan Pencegahan di Era Pandemi}

untuk mencegah penularan virus korona. Tindakan yang dimaksud berupa penggunaan masker; menjaga jarak dengan orang lain lebih dari 1 meter; mencuci tangan menggunakan air ditambah sabun atau hand rub berbasis alkohol; tetap tinggal di rumah apabila ada timbul gejala berupa batuk, demam, sakit kepala; hindari menyentuh bagian mata, hidung dan mulut sebelum dicuci terlebih dahulu (WHO, 2020). Dalam menerapkan berbagai tindakan pencegahan ini harus dilaksanakan sebagai satu kesatuan.

Selain melakukan berbagai tindakan pencegahan, penerapan pola hidup sehat juga perlu dilaksanakan. Aktivitas fisik yang rutin memiliki efek meningkatkan pelepasan IL-15 yang berperan dalam aktivasi dan proliferasi sel T, sel B dan sel Natural-Killer (NK). Aktivitas fisik yang direkomendasikan dilakukan selama 30 menit/hari selama 5 hari/minggu (atau 150 menit/minggu) (Jakobsson, 2020). Aktivitas fisik yang dapat dilakukan berupa olahraga dan mengerjakan pekerjaan rumah seperti berkebun, menyapu halaman/rumah, mencuci.

Kebiasaan merokok sebaiknya mulai dikurangi hingga menghentikan penggunaan rokok. Kebiasaan merokok dapat menurunkan antibodi didalam darah, mengurangi jumlah limfosit $\mathrm{CD}^{+}$, mengurangi aktivitas fagosit sehingga perokok lebih mudah terinfeksi. Perubahan gangguan imunitas pada perokok ini akan memulih dalam kurun waktu 6 minggu pasca perokok berhenti melakukan kebiasaan merokok (Benowitz, 2016). Selain itu, World Health Organization (WHO) menganjurkan untuk pola konsumsi asupan nutrisi untuk meningkatkan sistem imun. Asupan nutrisi yang dianjurkan berupa mengonsumsi makanan yang segar (tidak diawetkan); konsumsi sayur minimal 5 porsi beserta buah 4 porsi; konsumsi air yang cukup sekitar 8-10 gelas/perhari (2 Liter); hindari makanan yang digoreng, diawetkan, tinggi lemak, minuman yang bergula tinggi (seperti softdrink, sirup), minuman bersoda; batasi

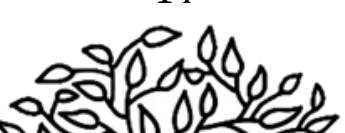


asupan garam sebanyak $5 \mathrm{~g}$ (sekitar 1 sendok teh/hari) (WHO, 2020).

Sebagai kesimpulan, di era pandemi COVID-19 ini diharapkan setiap orang dapat melaksanakan berbagai tindakan pencegahan dan pola hidup sehat. Semua ini bertujuan untuk melindungi diri sendiri dan juga orang lain. Dengan pencegahan dapat melindungi seseorang yang memiliki imunitas yang lemah atau penyakit penyerta (komorbid) sehingga orang-orang dengan kondisi tersebut tidak mudah untuk dijangkiti virus SARS-CoV-2.

\section{Daftar Pustaka}

Baratawidjaja, Karnen G., Rengganis, Iris. 2018. Imunologi Dasar. Jakarta: Badan Penerbit FK UI

Benowitz, Neal L., Brunetta, Paul G. Smoking Hazards and Cessation. In: Broaddus, Courtney V., Mason, Robert J., Ernst, Joel D., King, Talmadge E., Lazarus, Stephen C., Murray, John F., et al (eds). 2016. Murray \& Nadel's Textbook of Respiratory Medicine. Philadelphia: Elsevier Saunders

Centers for Disease Control and Prevention. Coronavirus Disease 2019 | People with Certain Medical Conditions. 2020 June. Available from: https://www.cdc.gov/coronavirus/2019ncov/need-extra-precautions/people-with-medicalconditions.html [accessed 29 June 2020]

Felsenstein, Susanna., Herbert, Jenny A., McNamara, Paul S., Hedrich, Christian M. 2020. COVID-19: Immunology and Treatment Options. Clinical Immunology. 2020 June; 215:108448. doi:10.1016/j.clim.2020.108448

Li, Xiaowei., Geng, Manman., Peng, Yizhao., Meng, Liesu., Lu, Shemin. 2020. Molecular Immune Pathogenesis and Diagnosis of COVID-19. Journal of Pharmaceutical Analysis. 2020 April; 10(2) : 102-108. doi: 10.1016/j.jpha.2020.03.001

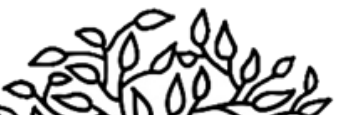




\section{Imunitas dan Pencegahan di Era Pandemi}

Liang, Wenhua., Guan, Weijie., Chen, Ruchong., Wang, Wei., Li, Jianfu., Xu, Ke., et al. 2020. Cancer patients in SARS-CoV-2 Infection: A Nationwide Analysis in China. Lancet Oncology. 2020 March 01; 21(3):335-337. doi:10.1016/S14702045(20)30096-6

Jakobsson, Johan., Malm, Christer., Furberg, Maria., Ekelund, Ulf., Svensson, M. 2020. Physical Activity During the Coronavirus (COVID-19) Pandemic: Prevention of a Decline in Metabolic and Immunological Functions. Frontiers in Sports and Active Living. 2020 April 30; 2:57. doi: 10.3389/fspor.2020.00057

World Health Organization. Coronavirus Disease (COVID-19) Advice for the Public. Available from: https://www.who.int/emergencies/diseases/novelcoronavirus-2019/advice-for-public [accessed 29 June 2020]

World Health Organization. Nutrition Advice for Adults During the COVID-19 Outbreak. Available from: http://www.emro.who.int/nutrition/nutritioninfocus/nutrition-advice-for-adults-during-the-covid-19outbreak.html [accessed 28 June 2020]

Ye, Qing., Wang, Bili., Mao, Jianhua. 2020. The Pathogenesis and Treatment of the 'Cytokine Storm' in COVID-19. Journal of Infection. $2020 \quad$ June $80(6): 607-613$. doi:10.1016/j.jinf.2020.03.037

Zheng, Jun. 2020. SARS-CoV-2: an Emerging Coronavirus that Causes a Global Threat. International Journal of Biological Sciences. $\quad 2020 \quad$ Mar 15;16(10):1678-1685. doi:10.7150/ijbs.45053 


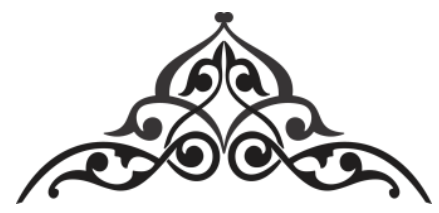

\title{
STRATEGI PEMBELAJARAN PENDIDIKAN
}

JASMANI, OLAHRAGA DAN KESEHATAN GUNA MENJAGA IMUNITAS TUBUH SISWA DI MASA PANDEMI COVID-19

\author{
Bakhrul Ulum, S.Or ${ }^{3}$ \\ SMKN 1 BANGIL
}

\begin{abstract}
"Guru diharapkan lebih kreatif dalam memilih Kompetensi Dasar yang sesuai, sebagai acuan tercapainya proses pembelajaran dalam masa pandemic."
\end{abstract}

aat ini penyebaran virus corona semakin meningkat, hal ini
dapat kita ketahui melalui informasi resmi yang disampaikan oleh Achmad Yurianto selaku juru bicara pemerintah Indonesia untuk Penanganan covid-19. Achmad Yurianto menyampaikan bahwa angka penyebaran covid-19 setiap harinya tidak dapat diprediksi dan grafiknya semakin meningkat serta peta penyebarannya semakin meluas di beberapa wilayah di Indonesia. Sebagai contoh pada tanggal 15 juni 2020 dari data resmi yang diperoleh bahwa yang dinyatakan positif covid-19 mencapai 39.294 orang, sembuh 15.123 orang, meninggal 2.198

3 Bakhrul Ulum, Penulis lahir di Pasuruan, 12 September 1983, Penulis merupakan guru SMK Negeri 1 Bangil Kabupaten Pasuruan dalam mata pelajaran Pendidikan Jasmani, olahraga dan Kesehatan (PJOK), Penulis menyelesaikan gelar sarjana Ilmu Keolahragaan di Universitas Negeri Malang (2007), penulis juga Aktif dikegiatan komunitas guru pendidikan jasmani olahraga dan kesehatan yan tergabung dalam MGMP ditingkat kabupaten, Propinsi dan Nasioanal. 
orang, hanya selang beberapa hari yaitu pada tanggal 29 juni 2020 angka orang yang dinyatakan positif covid- 19 sudah meningkat mencapai 55.092 orang, sembuh 23.800 orang dan meninggal 2.805 orang. Dari data tersebut dapat kita lihat bagaimana dalam waktu yang singkat angka penyebarannya begitu cepat sehingga orang yang positif covid-19 semakin bertambah,dan angka kematianpun semakin meningkat akan tetapi kita bisa sedikit bernafas lega karena angka yang dinyatakan sembuh juga semakin meningkat meskipun tidak sebanding dengan angka yang dinyatakan positif dan meninggal. Karena adanya kasus penyebaran covid-19 maka hal tersebut sangat berdampak pada berbagai bidang kehidupan di Indonesia, selain dampak nyata pada bidang perekonomian kasus covid-19 inipun juga berdampak pada dunia pendidikan di Indonesia. Bagaimana tidak, karena tingkat kerentanan penularan covid-19 ini semakin meningkat pada anak usia sekolah. Hal ini dibuktikan dengan adanya data bahwa per tanggal 30 mei 2020 anak yang positif tertular covid-19 sebanyak 1.851 anak dan meninggal dunia sebanyak 29 anak (Kompas.com). Dari data diatas tentu kita bertanya tanya, bagaimana bisa angka penyebaran covid-19 di kalangan anak sekolah bisa meningkat drastis sedangkan Kementerian Pendidikan dan Kebudayaan (Kemendikbud) menerbitkan Surat Edaran Nomor 15 Tahun 2020 tentang Pedoman Penyelenggaraan Belajar Dari Rumah Dalam Masa Darurat Penyebaran Covid-19.

Jadi dapat kita tarik kesimpulan bahwa anjuran untuk diam dirumah, istirahat cukup, jaga jarak serta rajin berolahraga kurang diindahkan oleh para siswa sehingga tingkat imunitas mereka rendah. Dengan adanya realita tersebut maka tugas kita sebagai guru terutama guru PJOK adalah membuat Strategi Pembelajaran Pendidikan Jasmani, Olahraga dan Kesehatan Guna Menjaga Imunitas Tubuh Siswa Dimasa Pandemi Covid-19 ini.

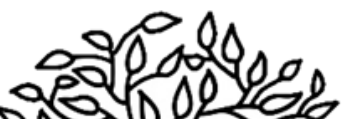


Dalam pembelajaran dimasa darurat covid-19 dibutuhkan keterampilan dan strategi Pembelajaran, terlebih pembelajaran Pendidikan Jasmani, Olahraga dan Keseharan (PJOK). Strategi pembelajaran adalah cara - cara yang akan dipilih dan digunakan oleh seorang pengajar untuk menyampaikan materi pembelajaran yang bertujuan untuk memudahkan peserta didik menerima dan memahami materi pembelajaran, yang pada akhirnya tujuan pembelajaran dapat dikuasainya di akhir kegiatan belajar.

Agar proses belajar mengajar tetap berjalan dengan lancar di masa pandemi covid-19 ini maka baik pengajar maupun siswa harus selalu menjaga daya tahan atau sistem imunitas tubuh mereka supaya tetap sehat selama masa belajar dari rumah. Sistem imunitas atau daya tahan tubuh secara sederhana dapat dipahami sebagai sistem kerja tubuh untuk melawan penyakit. Sistem ini akan melindungi tubuh dari serangan organisme atau kuman yang dapat menyebabkan penyakit. Sistem imunitas tubuh terdiri dari sistem imunitas bawaan dan sistem imunitas adaptif, adapun sistem imunitas bawaan merupakan lini pertahanan pertama terhadap patogen sedangkan sistem imunitas adaptif merupakan reaksi pertahanan tubuh yang disesuaikan atau diadaptasikan terhadap karakteristik antigen. Oleh karena itu, untuk meningkatkan sistem imunitas atau daya tahan tubuh salah satunya dapat dilakukan dengan berolahraga secara teratur. Pasalnya olahraga memungkinkan sel - sel kekebalan tubuh bekerja secara efektif, meningkatkan aliran darah, membantu membersihkan bakteri dari saluran pernafasan, membantu melawan infeksi, mengurani stres dan peradangan serta dapat memperkuat antibodi, sehingga olahraga sangat dibutuhkan selama masa pandemi covid-19.

Jika daya tahan tubuh atau sistem imunitas sudah baik maka kesehatan akan terjaga, dengan tubuh yang sehat tentunya proses pembelajaran akan berjalan dengan lancar. Salah satu

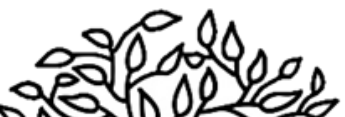


pengertian pembelajaran dikemukakan oleh Gagne (1977) yaitu pembelajaran adalah seperangkat peristiwa - peristiwa eksternal yang dirancang untuk mendukung beberapa proses belajar yang bersifat internal. Pengertian lain dari pembelajaran adalah proses interaksi peserta didik dengan pendidik dan sumber belajar pada suatu lingkungan belajar. Pembelajaran merupakan bantuan yang diberikan pendidik agar dapat terjadi proses perolehan ilmu dan pengetahuan, penguasaan kemahiran dan tabiat, serta pembentukan sikap dan kepercayaan pada peserta didik. Dengan kata lain, pembelajaran adalah proses untuk membantu peserta didik agar dapat belajar dengan baik.

Di masa pandemi covid-19 ini tentunya proses belajar mengajar tidak dapat dilakukan secara langsung dengan tatap muka,mengingat betapa cepatnya virus ini menyebar. Oleh karenanya Menteri Pendidikan dan Kebudayaan (Kemendikbud) membuat suatu kebijkan tentang proses pembelajaran selama pandemi covid-19 ini dengan mengeluarkan Surat Edaran No. 4 tahun 2020 salah satunya adalah proses belajar dari rumah (BDR). Proses belajar dari rumah selalu dikonotasikan sebagai pembelajaran daring atau pembelajaran jarak jauh (PJJ) yang identik dengan pembelajaran berbasis internet on line, harus dengan laptop atau telepon seluler (HP) berbasis android, padahal pembelajaran jarak jauh bisa dilakukan dengan cara antara lain seperti pemberian modul, lembar kerja, kelompok belajar, kerjasama dengan orang tua bagi siswa yang tidak memiliki perangkat teknologi jaringan. Proses belajar dari rumah (BDR) selain pembelajaran daring atau PJJ, prinsipnya adalah pembelajaran harus beroristasi kebermaknaan pengalaman bagi siswa dan tidak terbebani pencapaian ketuntasan kurikulum, serta fokus pada pembelajaran kecakapan hidup dimasa pandemi covid-19. Aktifitas tugas harus bevariasi antar siswa sesuai minat dan kondisi masing masing siswa, termasuk kesenjangan akses/fasilitas belajar dirumah. Bukti produk BDR

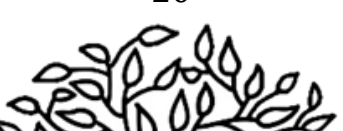


diberi umpan balik yang bersifat kualitatif, hal ini dapat dilihat pada Surat Edaran No 15 Kemendikbud Tahun 2020 mengenai Pedoman penyelenggaran BDR dalam masa darurat Penyebaran Covid-19 yang isinya tujuan pelaksanaan proses belajar dari rumah (BDR). Prinsip pelaksanaan proses belajar dari rumah (BDR) serta metode dan media pelaksanaan proses belajar dari rumah (BDR).

Dalam pembelajaran Pendidikan Jasmani Olahraga dan kesehatan di masa pandemi Covid-19, diperlukan pemilihan Kompetensi Dasar (KD) yang cocok guna tercapainya siswa yang memiliki imunitas tubuh yang baik sebagai acuan tercapainya proses pembelajaran. Jadi dimasa darurat pandemi covid-19 guru diharapkan untuk lebih kreatif dalam memilih kompetensi dasar yang sesuai untuk keadaan saat ini. Jika kompetensi pembelajaran mata pelajaran Pendidikan Jasmani Olahraga dan Kesehatan (PJOK) pada masa normal minimal harus mencapai 9 kompetensi, namun pada masa darurat covid-19 dan BDR saat ini, kompetensi dasar yang sesuai dan dapat mendukung untuk menjaga daya tahan tubuh atau sistem imunitas siswa adalah 3 kompetensi, antara lain: (1) aktivitas kebugaran jasmani, (2)senam ritmik, (3)atletik (lari dan jalan).

Agar pembelajaran Pendidikan Jasmani Olahraga dan Kesehatan (PJOK) yang bertujuan untuk meningkatkan imunitas tubuh siswa dapat maksimal maka dibutuhkan catatan atau media sebagai pengontrol proses pembelajaran. Media yang digunakan bisa menggunakan Kartu Gerak Aktifitas. Kartu Gerak Aktifitas merupakan sebuah media pembelajaran PJOK yang memuat pilihan tugas proses belajar mengajar aktifitas gerak yang isinya terdiri dari 2 sisi. Sisi yang pertama yaitu sisi depan, dan sisi satunya yaitu sisi utama. Sisi depan berisi tentang biodata siswa mulai dari nama, kelas, jurusan (kalau SMK), tinggi badan (TB), berat badan (BD), sedangkan sisi utama berisi

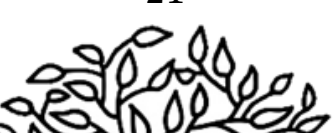


tentang tugas gerak, aktivitas kebugaran jasmani, komponen komponen kebugaran jasmani.

Dalam pencapaian tujuan pembelajaran yang berorientasi pada keberhasilan peningkatan imunitas tubuh siswa maka perlunya strategi pembelajaran Pendidikan Jasmani Olahraga dan Kesehatan (PJOK) yang sesuai dengan situasi saat ini yaitu siswa belajar dari rumah (BDR). Disisi lain pembelajaran jarak jauh (PJJ) dengan daring menggunakan aplikasi yang menghabiskan banyak kuota paket internet seperti pembelajaran dengan metode zoom dan sebagainya belum mencapai hasil yang maksimal dalam menjawab tantangan proses belajar dari rumah (BDR) karena menimbulkan permasalahan yang lain yaitu menjadi beban finansial siswa dan orang tua dalam masa pandemic covid-19 ini. Oleh karena itu dipilihlah pembelajaran on line dengan menggunakan aplikasi sosial media yang paling murah sehingga tidak banyak menghabiskan kuota paket internet, media tersebut adalah whatsapps. Jadi whatsapp sebagai media atau alat komunikasi dan timbal balik antara siswa dan guru serta dikombinasikan dengan Kartu Aktifitas Gerak. Kartu Aktifitas Gerak adalah sebagai pengontrol siswa dalam melakukan pembelajaran sekaligus sebagai alat pencatat apakah siswa sudah melakukan aktifitas gerak sesuai kompetensi dasar yang diinginkan, seperti melakukan pengukuran tinggi badan, berat badan, denyut nadi awal dan denyut nadi latihan, dengan kartu ini pula kita bisa mengetahui apakah siswa sudah melakukan (1) kebugaran jasmani, missal: Sit up 1 menit, Push Up 1 menit, lompat tegak 1 menit (2) melakukan senam ritmik semisal senam SKJ 2018 atau senam irama lainnya serta (3) melakukan aktivitas atletik semisal melakukan jogging atau lari dengan jarak 10 meter selama 5 menit dan melakukan jalan bolak balik selama 15 menit.

Dalam hal ini Kartu Aktifitas Gerak mencatat kegiatan harian pencapaian siswa melakukan aktivitas gerak. Semisal

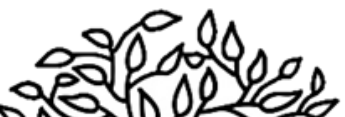


siswa A melakukan push up selama 1 menit maka dalam Kartu Aktifitas Gerak yang di catat adalah waktu pelaksanaan serta pencapaian push up dalam waktu 1 menit mendapatkan berapa kali, siswa B melaksanakan lari atau jogging maka Kartu Aktifitas Gerak sebagai hasil progres bahwa dalam 1 menit siswa B melakukan lari dengan jarsk 10 meter mendapatkan berapa putaran, setelah itu baru dicatat denyut nadi setelah latihan di kartu aktifitas. Jadi kelas whatsapp ini sebagai media timbal balik antara guru dan siswa sekaligus sebagai penilaian dan evaluasi guru dengan cara hasil catatan di bagikan ke kelas Whatsapp sehingga guru bisa mengetahui keaktifan siswa dalam proses pembelajaran.

\section{DAFTAR PUSTAKA}

Agus Wijaya, Made (2019), Media Pembelajaran Aktivitas Pengembangan PJOK Untuk Pendididakn Dasar dan Menengah. Journal of Sport Scienc And Education (JOSSAE) Vol: 4:(1-6)No:1 April (2019).

Gagne (1977), Pengertian Pembelajaran. Direktorat Pendidikan dan Pembelajaran Diunggah dari Web: https://unida.ac.id/pembelajaran/ 29 Juni 2020

Kementrian Pendidikan dan Kebudayaan RI. Diunggah dari web :

Surat Edaran Sesjen No.15 tahun 2020 tentang Pedoman Pelaksanaan BDR selama darurat Covid19. Diunggah dari Web: https://pusdiklat.kemdikbud.go.id/. 29 Juni 2020

Kementrian Pendidikan dan Kebudayaan RI. Surat Edaran Mendikbud No. 4 Tahun 2020 tentang Pelaksanaan Kebijakan pendidikan dalam Masa darurat Penyebaran corona virus Disease Diunggah dari web : https://pusdiklat.kemdikbud.go.id/. 29 Juni 2020

Setyvani P, Gloria. (2020), Kematian Anak Indonesia karena Corona Tertinggi di ASEAN, Diunggah dari web : https://www.kompas.com/sains/read. 29 Juni 2020

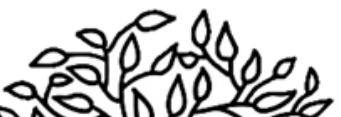


| Strategi Pembelajaran Pendidikan Jasmani, Olahraga dan... 


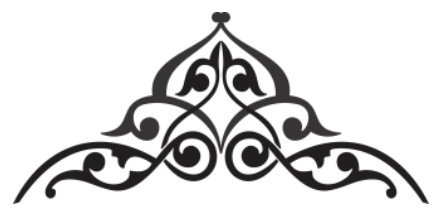

\title{
NUTRISI DALAM MENINGKATKAN IMUNITAS TUBUH PADA MASA PANDEMI COVID-19
}

\author{
Nenni Dwi Aprianti Lubis, SP., MSi ${ }^{4}$ \\ Fakultas Kedokteran Universitas Sumatera Utara
}

"Tindakan pencegahan seperti penggunaan masker, mencuci tangan, menjaga jarak sosial (social distancing/physical distancing), berolahraga dan istirahat yang cukup adalah kunci untuk menurunkan risiko terpapar COVID-19"

$\mathrm{P}$ ada awal tahun 2020, dunia dikejutkan dengan mewabahnya penyakit pneumonia baru yang bermula dari Kota Wuhan, Provinsi Hubei China yang kemudian menyebar secara cepat dan meluas. Wabah ini diberi nama Coronavirus Disease 2019 (COVID-19) yang disebabkan oleh Severe Acute Respiratory Syndrome Coronavirus-2 (SARS-CoV-2). Virus ini dapat ditularkan dari manusia ke manusia dan telah menyebar di China dan lebih dari 190 negara di dunia. Pada 12 Maret 2020, WHO mengumumkan COVID-19 sebagai pandemi. Hingga tanggal 27 Juni 2020, terdapat 9.653.048 kasus dan 491.128 jumlah kematian di seluruh dunia. Di Indonesia, pada tanggal yang sama

${ }^{4}$ Nenni Dwi Aprianti Lubis lahir di Medan, 10 April 1976, penulis merupakan Dosen Tetap pada Departemen Ilmu Gizi Fakultas Kedokteran Universitas Sumatera Utara sejak tahun 2003, penulis menyelesaikan jenjang pendidikan strata satu pada Prodi Gizi Masyarakat dan Sumberdaya Keluarga, Fakultas Pertanian, Institut Pertanian Bogor dan memperoleh gelar Magister Sains pada Prodi Ilmu Pangan dari institusi yang sama. 
Nutrisi dalam Meningkatkan Imunitas Tubuh pada Masa...

COVID-19 mencapai 52.812 kasus dengan jumlah kematian sebanyak 2.720 jiwa.

Angka kasus terkonfirmasi virus korona (COVID-19) secara global mengalami peningkatan setiap harinya. Tindakan pencegahan seperti penggunaan masker, mencuci tangan dengan menggunakan sabun, menjaga jarak sosial (social distancing/physical distancing), berolahraga dan istirahat yang cukup adalah kunci untuk menurunkan risiko terpapar penyakit ini. Namun dalam mempersiapkan sistem kekebalan tubuh dibutuhkkan pola makan yang sehat dapat membantu meningkatkan imunitas tubuh dalam menghadapi pandemi ini.

Sistem kekebalan tubuh atau sistem imun merupakan komponen vital dalam menghadapi berbagai jenis patogen penyebab infeksi seperti bakteri, virus dan jamur. Sistem imun di tubuh manusia dibedakan atas sistem imun bawaan (innate) dan didapat (adaptive). Disebut sebagai sistem imun bawaan, dikarenakan telah ada serta siap berfungsi sejak manusia dilahirkan untuk menghadapi semua agen patogen yang masuk (nonspesifik). Sedangkan pada sistem imun didapat, tubuh haruslah mengenal terlebih dahulu agen patogen yang menyerangnya sehingga bila ada serangan kedua kalinya dari patogen yang sama maka respon sistem imun didapat akan bekerja lebih cepat untuk membunuh agen patogen tersebut (spesifik).

Sistem imun akan bekerja saat merasakan kehadiran suatu agen patogen dan memerlukan berbagai zat penghasil energi seperti glukosa, asam lemak dan asam amino untuk dapat mengaktivasinya. Respon imun membutuhkan DNA, RNA, protein, kompleks lemak dan substrat lainnya untuk proses proliferasi berbagai sel imunnya. Demikian pula dengan vitamin dan mineral yang berguna dalam peningkatan respon imun. Berikut ini adalah berbagai zat gizi yang berperan dalam meningkatkan daya tahan tubuh.

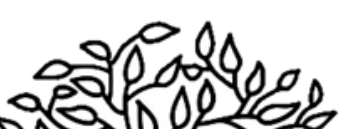


A. Vitamin A

Bentuk retinol dari vitamin A memiliki peranan penting dalam pertumbuhan dan diferensiasi sel limfosit B, selain itu vitamin A juga mengatur pematangan sel imun neutrofil. Kekurangan vitamin A di tubuh akan meningkatkan jumlah sel neutrofil hanya saja tidak dapat berfungsi secara efektif. Kondisi kekurangan vitamin A juga menyebabkan penurunan aktivitas natural-killer cell (sel NK) yang dapat melemahkan pertahanan tubuh terhadap virus. Sumber vitamin A yang paling baik diperoleh dari pangan hewani seperti hati sapi, minyak ikan dan kuning telur. Sayuran berwarna hijau tua dan buah-buahan berwarna kuning jingga juga merupakan sumber vitamin A dari pangan nabati.

B. Vitamin Grup B

Vitamin B berperan pada regulasi sistem imun di saluran cerna. Kekurangan vitamin B6 menyebabkan efek atrofi pada timus dan limpa, penurunan jumlah limfosit $\mathrm{T}$ dan gangguan respon limfosit T. Pada defisiensi vitamin B12 berakibat pada penurunan kemampuan fagositik dan eliminasi bakteri oleh sel neutrofil. Selain itu asam folat, vitamin B6 dan vitamin B12 juga berperan dalam memicu aktivitas sel NK dan sel $\mathrm{T}$ sitotoksik (CD8+) dalam menghadapi infeksi virus. Vitamin B6 banyak ditemukan pada khamir, gandum, hati, serealia, kacang dan pisang. Hati ayam, hati sapi, sardin, kuning telur dan keju merupakan pangan sumber vitamin B12. Terakhir, bahan pangan sumber asam folat dapat ditemukan pada sayuran hijau, buah jeruk, hati ayam, daging dan pangan laut seperti ikan, kepiting, ganggang laut.

C. Vitamin C

Dalam pembentukan kolagen dan mempertahankan integritas sel epitel diperlukan vitamin C. Vitamin ini juga berfungsi dalam respon imun seperti migrasi sel imun

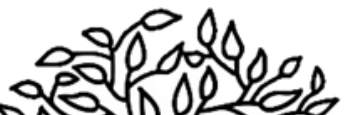


Nutrisi dalam Meningkatkan Imunitas Tubuh pada Masa...

menuju lokasi infeksi, fagositosis, aktivitas sel NK dan produksi antibodi. Seseorang yang mengalami defisiensi vitamin $C$ lebih rentan mengalami infeksi pernapasan seperti pneumonia. Pangan nabati seperti sayur dan buah yang asam (jeruk, papaya, jambu, nanas, mangga) merupakan sumber vitamin C.

D. Vitamin D

Vitamin D membantu dalam differensiasi monosit menjadi makrofag dan peningkatan aktivitas fagositosis. Vitamin D dapat diperoleh dari sinar matahari dan makanan. Sumber makanan yang kaya vitamin D seperti kuning telur, mentega, krim, hati dan minyak hati ikan.

E. Vitamin E

Fungsi vitamin E membantu interaksi antara sel dendritik dan limfosit $\mathrm{T}$ CD4+. Uji coba pada hewan menunjukkan bahwa suplementasi vitamin E meningkatkan produksi antibodi, proliferasi limfosit dan peningkatan aktivitas fagositosis makrofag dan sel NK. Vitamin E hanya dapat ditemukan pada pangan nabati yakni minyak tumbuhtumbuhan, biji-bijian dan gandum.

F. Zinkum

Mineral zinkum dapat menghambat polimerasi RNA yang digunakan oleh virus RNA (seperti virus korona) untuk bereplikasi. Kemampuan ini dipercaya dapat menghambat aktivitas virus RNA untuk merusak tubuh. Selain itu, defisiensi zinkum dapat menurunkan produksi antibodi dan jumlah limfosit $\mathrm{B}$ serta proliferasi sel $\mathrm{T}$ sitotoksik yang berperan dalam pertahanan menghadapi virus. Sumber zinkum dapat dijumpai pada daging, hati, serealia dan kacang-kacangan.

Sebagai penutup, Badan Kesehatan Dunia telah mengeluarkan suatu pedoman pola makan sehat untuk

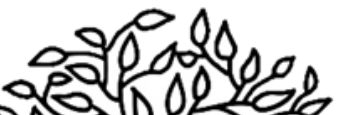


meningkatkan sistem imun selama pandemi COVID-19 sekaligus mengurangi risiko penyakit kronis meliputi:

- Konsumsi makanan yang segar setiap hari yang terdiri dari 5 porsi sayuran, 4 porsi buah-buahan, 180 gram kacangkacangan/serealia serta 160 gram pangan hewani. Daging boleh dikonsumsi 1-2 kali/minggu.

- Konsumsi air yang cukup sejumlah 8-10 gelas (sekitar 2 liter) per hari. Diperbolehkan juga untuk mengkonsumsi jus, teh dan kopi serta membatasi minuman yang mengandung pemanis dan soda.

- Konsumsi produk perikanan dan olahannya, alpukat, minyak zaitun, dan minyak jagung sebagai bahan pangan sumber lemak tak jenuh dan menghindari makanan cepat saji, makanan yang digoreng dan makanan beku.

- Membatasi konsumsi garam di bawah 5 gram atau sekitar 1 sendok teh setiap harinya .

\section{Daftar Pustaka}

Almatsier, Sunita. 2010. Prinsip Dasar Ilmu Gizi. Jakarta: Penerbit PT Gramedia Pustaka Utama.

Baratawidjaja, Karnen Gana, Rengganis, Iris. 2018. Imunologi Dasar. $12^{\text {th }}$ ed. Jakarta: Badan Penerbit FK UI.

Calder PC. 2020. Nutrition, immunity and COVID-19. BMJ Nutrition, Prevention \& Health;bmjnph-2020-000085. Doi: 10.1136/bmjnph-2020-000085

World Health Organization. WHO Director-General's opening remarks at the media briefing on COVID-19 - 11 March 2020 [Internet]. 2020 [updated 2020 March 11].

Available

from:

https://www.who.int/dg/speeches/detail/who-directorgenerals-opening-remarks-at-the-media-briefing-on-covid19---11-march-2020

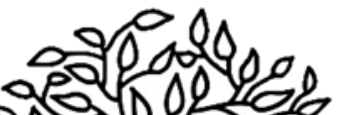


| Nutrisi dalam Meningkatkan Imunitas Tubuh pada Masa...

World Health Organization. Nutrition advice for adults during the COVID-19 outbreak. Available from: http://www.emro.who.int/nutrition/nutritioninfocus/nutrition-advice-for-adults-during-the-covid-19outbreak.html 


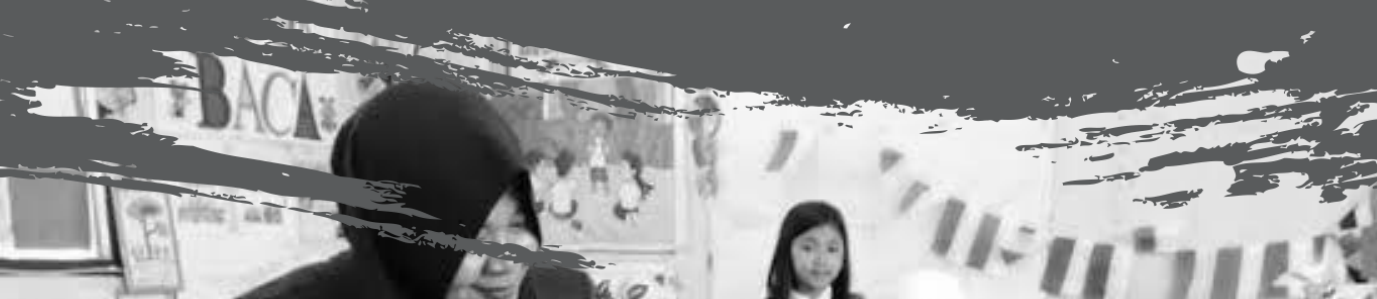

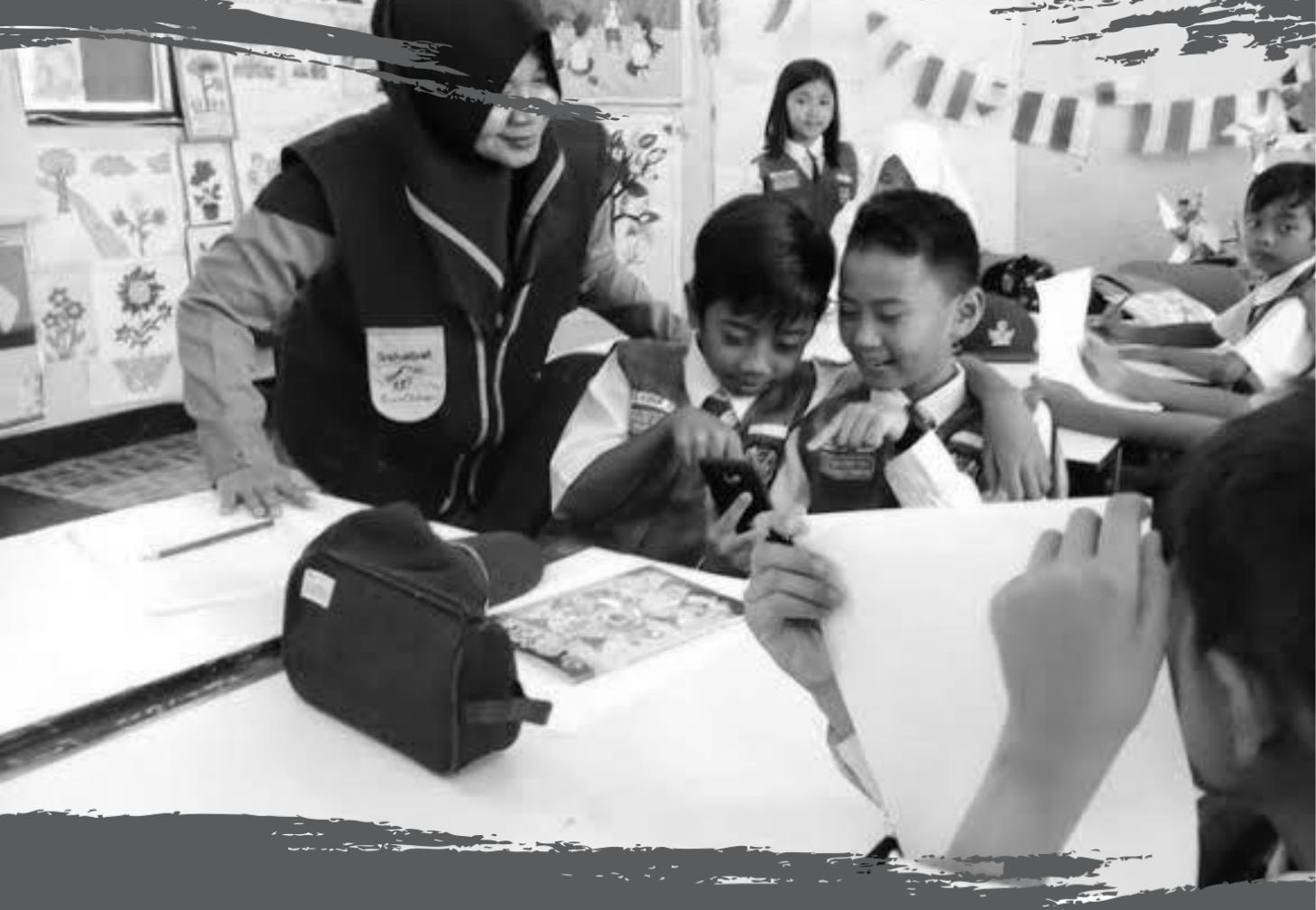

\section{BAB II}

KESEHATAN MENTAL DAN 


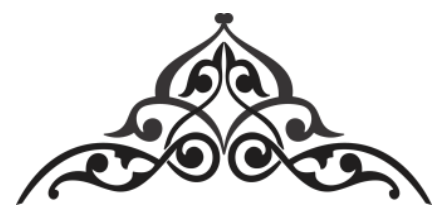

\title{
PRODUKTIVITAS DIRI DAN KESEHATAN MENTAL DI ERA NEW NORMAL
}

\author{
Pasiska $^{5}$ \\ STAI-Bumi Silampari Lubuklinggau
}

"Bila tubuh sehat, pikiran jernih, seseorang dapat melakukan hal-hal yang produktif. Hal yang paling penting adalah menjaga Kesehatan mental dengan mendekatkan diri kepada Tuhan Yang Maha Esa melalui membangun kualitas spiritualitas"

\section{Pendahuluan}

Wetika masa krisis yang terjadi diakibatkan oleh wabah Nmelanda dimulai di China tepatnya di Kota Wuhan (Bali.idntimes.com/, 2020), sontak membuat public jagat maya dan dunia gempar melihat banyak jatuh korban oleh wabah virus corona tersebut kian menyebar dengan cepat dan ganas. Korban mulai berjatuhan tak terkendalikan mulai dari yang meninggal dunia dari anak kecil hingga dewasa, hal itu dapat ditandai mulainya sesak nafas yang dialami para korban keganasan virus ini. Lalu ditambah ketika dijalan-jalan banyak masyarakat berjatuhan dan meninggal dunia entah di pusat perbelanjaan,

5 Pasiska merupakan Alumni STAI-BS Lubuklinggau dengan Program Studi Pendidikan Agama Islam dan Alumni UIN SUKA Yogyakarta Konsentrasi Psikologi Pendidikan Islam, penulis juga aktif menulis di jurnal, buku dan aktif mengajar Di Kampus STAI-BS Lubuklinggau 
pelayanan public, bank dan tempat keramian lainnya tak terkecuali di tempat fasilitas Kesehatan masyarakat.

Kemudian dilanjutkan dengan mudahnya menular virus ini kepada masyarakat, terutama bagi mereka yang menyentuh korban secara langsung atau terlibat aktivitas secara langsung maka akan mudah tertular dan menjadi kategori berstatus korban yang harus dikarantina sebab kalau dibiarkan saja maka akan membuat orang lain yang belum tertular serta menambah banyak korban hal itu semakin hari semkain bertambah dan tak terkendalikan, bahkan korban yang banyak meningga dunia mereka relawan atau tenaga Kesehatan yang merawat dan mengobati para korban terinfeksi dari virus tersebut. Setelah mewabah dan menyebar luas di daerah wuhan china dengan pesatnya, hal tersebut juga berdampak dan mulai menyebar ke beberapa negara-negara lainnya seperti jepang, korea selatan, Thailand, Vietnam, Singapura, Indonesia hingga ke beberapa negara-negara Eropa dan Amerika(Rohmi, 2020b).

Fenomena pandemic ini seakan menjadi hal menakutkan, semua orang di buat takut olehnya seakan-akan alam bawah sadar merespon kata-kata virus corona merupakan hal yang membahayakan dan harus di jauhi, belum lagi pada saat wabah terjadi belum di temukannya obat yang mujarab atau ampuh untuk menanggulagi penyakit tersebut (Rohmi, 2020a). Akhirnya menjadi maindset(Dweck, 2006) bagi Sebagian besar orang virus tersebut sangat-sangat membahayakan, kemudian di tambah oleh adanya larangan aktivitas diluar rumah, baik dalam bekerja, aktivitas social, aktivitas keagamaan, Pendidikan dan bahkan aktivitas ekonomi itu sendiri (Rahmad, 2020). Sebab kekhawatiran tersebut bukan pada aspek untuk menghidarkan diri dari menularnya virus tersebut akan tetapi lebih ke pada membuat sesorang merasa tertekan, ketakutan dan bahkan hysteria yang berlebihan dan pada akhirnya. Kesehatan mental seseorang menjadi terganggu karena traumatic cukup mendalam

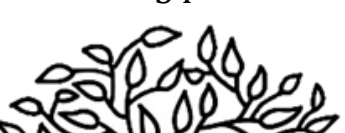


membekas tersimpan dengan baik di alam bawah sadar, ketakutan tersebut tidak lain lahir dari kecemasan hingga membuat mental seseorang menjadi terganggu belum lagi Sebagian aktivitas dilakukan di rumah saja pun juga membosankan serta kebanyakan kurang diminati, hanya disibukkan dengan makan minum dan aktivitas social media, menonton $\mathrm{tv}$, belum lagi stok uang dan bahan makanan mulai menipis sebab kerja dan beraktifitas lainnya hanya bisa dilakukan dirumah, bagi Sebagian orang sudah terbiasa beraktifitas di luar tentu saja sangat terpukul, merasa dirinya tidak bebas mencari nafkah dan beraktifitas lainnya. Keadaan tersebut membuat Kesehatan mental terpukul dan terganggu karena ketakutan yang terjadi, dan upaya yang harus dilakukan dalam mengisi waktu luas dirumh hruslah diisi dengan produktif.

\section{Pembahasan}

Warga negara Indonesia ketika fenomena yang mulai mewabah dan menyebar di Asia Tenggara maka pada saat itu juga mulai di berkalukannya social distancing dan memberlakukan segala aktivitas normal diluar dilakukan dirumah saja kondisi terjadi demikian memaksa kita mau tidak mau harus melakukan karantina mandiri dengan beraktifitas hanya dirumah, pada kejadian ini otomatis membuat segala aktifitas terasa kurang bebas oleh sebab hari-hari yang dilalui hanya dirumah membuat Sebagian besar orang merasa bosan akibat aktifitas yang dilakukan hanya satu kegiatan, apa lagi bagi mereka tidak memiliki kegiatan yang cukup produktif dan hanya bisa dilakukan diluar rumah, maka otomatis dapat menurunkan produktifitas diri, karena dirumah Cuma bisa makan dan tidur maka otomatis ada Sebagian orang bisa saja stress ringan, bukan karena kejenuhan yang dialamai ketika di rumah akan tetapi maindset didalam diri akan bahaya dari adanya virus tersebut bukan lagi hanya pada skala biasa dalam membunuh tetapi bisa membuat takut secara berlebihan.

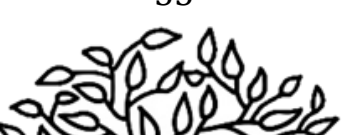


Ketakutan tersebut secara otomatis akan menghambat seseorang dalam segala bidang trutama dalam beraktifitas yang lebih produktif, pada akhirnya stress yang dialami dapat mnjadijadi dan skalanya bisa meningkat bahkan bila dibiarkan bisa menyebabkan kegilaan atau perubahan perilaku normal menjadi abnormal, sehingga peningkatan jumlah orang sakit dapat meningkat.

Seakan wabah yang terjadi tiada hentinya belum lagi dari efek dari wabah tersebut bukan hanya dapat merukan dari tinjauan ekonomi, akan tetapi dalam segi Kesehatan jiwa bagi sebagin besar masyarakt akan sangat berdampak meskipun sejatinya belum terkena atau belum secara positif terkena wabah virus ini, namun Kesehatan mental dapat terganggu, untuk itu dibutuhkan antisipasi belum lagi fenoma ini bila dibiarkan begitu saja maka hampir segala aktifitas terhambat dan yang vital yakni ekonomi bila tidak diselesaikan maka tidak sedikit mucul wabah baru dari social masyrakat itu sendiri, seperti kriminalitas, kelapran dan bahkan dapat menyebabkan negara menjadi bubar. Maka inisiatif pemerintah dan WHO memberlakukan pandemic ini sebagai sesuatu yang biasa atau sering disebut memulai kehidupan baru New Normal (NN)(Jaya, 2020) dimana kita bisa melakukan aktifitas seperti biasanya dengan menggunakan standar Kesehatan, namun ketika mulai diberlakukannnya NN tersebut Kesehatan mental masyarakat dapat pulih Kembali? Pertanyaan tersebut harunya difahami dan dilihat secara mendalam oleh sebab kebanyakn kepanikan dan ketakutan yang berlebihan tentu saja berdampak kepada perubahan psikis dan prilaku, sudah dipastikan ketakutan tersebut masih nampak terlihat meskipun NN sudah diberlakukan.

Maka dari itu penulis dari pengalaman dan beberapa penelitian yang dimuat pada artikel berupaya membuka cakrawala kita seluas-luasnya tentang merawat diri dalam hal ini tetap produktif dan juga tetap menjaga Kesehatan mental dan

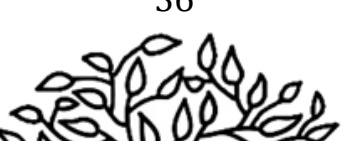


Kesehatan diri. Salah satu upaya-upaya yag dilakukan tidak lain sebagai berikut:

Menurut Seligman ada tiga cara yang tepat untuk memperoleh suatu Kesehatan mental dengan tips-tips positif (Seligman, 2002) , yaitu:

1. Miliki kehidupan yang menyenangkan: melakuakan segala aktifitas yang baru saja dimulai pada saat $\mathrm{NN}$ harus dilakukan dengan senang hati, merasa tanpa beban, dengan konsep syukur dan ikhlas menjalani setiap kegiatan dengan keyakinan hati, merubah pandangan tidak ada yang suit jikalau dijalani.

2. Miliki kehidupan yang baik: dalam menjalankan kehidupan baik bukan hanya dalam hal tidak melakukan kriminalitas atau merugikan orang namun dalam hal ini memiliki kehidupan baik salah salah satunya dengan cara menjaga Kesehatan melalui kebersihan baik kebersihan fisik maupun kebersihan hati hal itu dapat ditempuh melalui jalan olah raga, olah pikiran, olah rasa dan olah keimanan dan barengi dengan kehidupan yang baik dengan tidak melakukan hal-hal buruk seperti kriminalitas, narkoba dan hal lainnya yang dapat merugikan diri sendiri dan orang lain.

3. Miliki kehidupan bermakna: setelah melakukan hal yang baik lagi menyenangkan maka kini biar terasa membekas didalam alam bawah sadar, yang harus dilakuakan bagaimna kesemuanya yang dilakukan untuk kehidupan kita harus memiliki makna, setidaknya kebermaknaan itu dengan cara memulai mengaktualisasi segala ang sudah diwacanakan sebagai sebuah perencanaan dalam kehidupan yang baik, salah satunya memulai untuk memberikan sesuatu yang bermanfaat baik bagi diri sendiri, orang lain dan alam iniseperti contoh menghargai diri sendiri dan tidak membiarkannya sakit ataupun rusak oleh aktifitas kita sendiri, lalu bagi orang lain setidaknya mampu

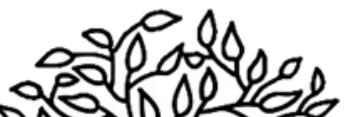


menghargainya, jikalau ada kelebihan materi yang dapat disalurkan apasalahnya dibagikan dengan menjunjung tinggi atas nama kemanusiaan dan persaudaraan, dan untuk alam ini minimal kita tidak merusaknya dan memanfaatkannya sesuai dengan kebutuhan.

Kemudian hal itu juga sangat relevang dengan kajian Islam ketika menjaga Kesehatan mental dalam islam menjaga Kesehatan mental ada berbagai cara salah satunya dengan cara sholat (Pasiska, 2020), sholat dalam Islam merupakan sebuah kewajiban yang mutlak yang harus dilakukan 5 waktu selama 17 rakaat. Akan tetapi lebih dari itu bahwa dengan melakukan sholat seseorang dapat menjadi tenang sebagaimana hadits nabi.

Diriwayatkan oleh Hudzaifah Radhiyallahu 'anhu bahwa ia berkata: "Jika Nabi Shallallahu Alaihi Wasallam merasa gundah karena sebuah perkara, maka beliau menunaikan shalat" (Hadis Riwayat. Abu Daud, No. 1319).

Hadits tersebut sangat relevan jika dilihat dengan fenomena yang terjadi saat ini yakni kondisi pandemic corona virus dapat membuat seseorang menjadi panik dan ketakutan luar biasa hingga menjadi phobia akan virus tersebut dan mampu menyebabkan terganggunya Kesehatan mental, untuk itu dengan sholat dapat dicegah dan mampu meningkatkan kondisi tubuh Kembali normal dan tenang.

Kemudian firman Allah SWT b: “Wahai orang-orang yang beriman! Mohonlah pertolongan (kepada Allah) dengan sabar dan shalat. Sungguh, Allah beserta orang-orang yang sabar". (Q.S. 153) (Al-Qur'an \& Terjemah, n.d.) Dan Firman-Nya: "Dan Kami pasti akan Menguji kamu dengan sedikit ketakutan, kelaparan, kekurangan harta, jiwa, dan buah-buahan. Dan sampaikanlah kabar gembira kepada orang-orang yang sabar" Q.S. Al Baqarah: 155(Al-Qur'an \& Terjemah, n.d.)

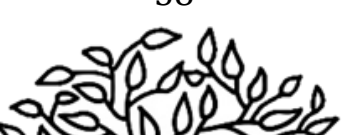


Ketika dalam posisipanik atau ketakutan yang dialami seseorang, tubuh yang mengalami panik dipaksa mengeluarkan reaksi biologis seperti mengeluarkan hormon andrenalin sebagai persiapan untuk menghadapi kondisi tertentu. Hal itu dapatmemicu perubahan jiwa dan pikiran karena kondisi susunan syarat terpengaruh dan keadaan kelenjar endokrin yang reaktif.

Selain manfaat psikoterapi untuk kesehatan mental, shalat juga bermanfaat dalam pembentukan mental seseorang di antaranya mengajari bagaiamana menghargai waktu, disiplin dan sungguh-sungguh dalam melaksanakan aktivitas (Pasiska, 2020). Kekuatan spritual juga mampu membangkitkan harapan, memantapkan tujuan, memperkokoh semangat, dan memunculkan kekuatan yang membuat seseorang siap menerima ilmu pengetahuan dan hikmah.

Apabila tubuh sehat dengan pikiran yang jernih otomatis seseorang dapat melakukan hal-hal yang produktif, hal produkti bisa saja dilakukan aktifitas dirumah salah satunya membaca buku, kemudian belajar menjahit, menulis buku atau puisi, kemudian aktifitas lainnya yang lebih produktif yakni memanfaatkan halaman pekarangan untuk ditanami tanaman yangproduktif, bisa juga ditanami tanaman hias atau janaman rempah. Hal itu bisa dilakukan ketika dirumah dan masih banyak lagi aktifitas yang positif yang bisa membantu produktifitas seseorang sehari-hari untuk hal yang paling penting adalah menjaga Kesehatan mental salah satunya dengan mendekatkan diri kepada Tuhan Yang Maha Esa melalui membangun kualitas spiritualitas kita dengan rutin dan penuh dedikasi, demikianlah ulasan singakat untuk menjaga diri agar tetap sehat mental dan ketika Kesehatan mental dapat membuat diri produktif.

\section{Daftar Pustaka}

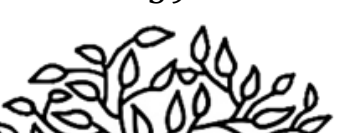


Al-Qur'an \& Terjemah. (n.d.).

Bali.idntimes.com/. (2020). Asal Mula dan Penyebaran Virus Corona dari Wuhan ke Seluruh Dunia. https://bali.idntimes.com/health/medical/dennyadhietya/asal-muasal-dan-perjalanan-virus-corona-dariwuhan-ke-seluruh-dunia-regional-bali

Dweck, C. S. (2006). Mindset: The New Psychology of Success (1st ed.). Printed USA.

Jaya, T. P. (2020). Peringatan WHO untuk Indonesia soal Persiapan New Normal. https://www.kompas.com/tren/read/2020/06/13/12150 0765/peringatan-who-untuk-indonesia-soal-persiapannew-normal?page $=$ all

Pasiska, N. K. R. W. K. W. (2020). MENJAGA KESEHATAN MENTAL DENGAN PENDEKATAN SHALAT: ANALISIS SANAD DAN MATAN HADIS. Jurnal Bimbingan Penyuluhan Islam, 1(2), 227-250.

Rahmad. (2020, June). Daftar Larangan PSBB untuk Cegah Covid19. CNNNews.Com.

https://www.cnnindonesia.com/nasional/2020040502091

3-12-490389/daftar-larangan-psbb-untuk-cegah-covid-19

Rohmi, N. (2020a, March 29). Mengapa Obat untuk Virus Corona Tak Juga Ditemukan? Hala. Kompas.Com. https://www.kompas.com/tren/read/2020/03/29/13060 0965/mengapa-obat-untuk-virus-corona-tak-jugaditemukan-?page=all

Rohmi, N. (2020b, June 29). Update Virus Corona di Asia Tenggara: Indonesia Tertinggi, Jauh di Atas Singapura Halaman all - Kompas.com. Kompas.Com. https://www.kompas.com/tren/read/2020/06/29/05580 0065/update-virus-corona-di-asia-tenggara--indonesiatertinggi-jauh-di-atas?page=all

Seligman, M. E. P. (2002). Authentic Happiness: Using the New Positive Psychology to Realise your. NB Publishing.

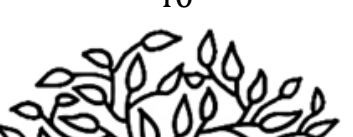




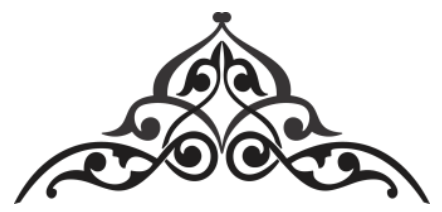

\title{
UPAYA GURU MEMBENTUK KARAKTER \\ SOSIAL SISWA DALAM PEMBELAJARAN DARING DI MASA PANDEMI COVID-19
}

\section{Nur Saadah, S.Sos 6 \\ MAN 1 Grobogan}

\author{
"Ketika seluruh bangsa Indonesia memasuki era \\ globalisasi bidang teknologi /era digital, maka jati diri \\ bangsa Indonesia sebagai bangsa dengan tingkat \\ solidaritas sosial yang tinggi, harus tetap \\ dipertahankan"
}

Dendidikan secara umum dikatakan sebagai suatu proses
mendayagunakan akal manusia agar dia menjadi manusia yang seharusnya bagaimana manusia. Bisa dikatakan membentuk manusia yang berbudaya.

Pendidikan adalah suatu proses transfer ilmu pengetahuan, sikap, perilaku, teknologi, dan budaya, sehingga peserta didik memiliki apa yang ditransfer tersebut dan menjadikannnya manusia yang berbeda, dari yang tadinya belum tahu menjadi tahu, dari yang belum berakhlak menjadi berakhlak, dan seterusnya. Dalam masyarakat dikenal istilah Tri pusat

${ }^{6}$ Nur Saadah lahir di Grobogan, 12 Agustus 1974, penulis merupakan Guru di MAN 1 Grobogan Mata Pelajaran Sosiologi. Penulis menyelesaikan gelar Sarjana Sosial di Fakultas Ilmu Sosial dan Ilmu Politik Jurusan Sosiologi Universitas Sebelas Maret [ UNS ] Surakarta Tahun 1998, Kemudian mengambil Program AKTA IV Jurusan Ilmu Pendidikan di Fakultas Keguuruan dan Ilmu Pendidikan [FKIP] Universitas Sebelas Maret [ UNS ] Surakarta Tahun 2001 
pendidikan terdiri dari Pendidkan informal [ dalam lingkungan keluarga ] , Pendidikan formal [ dalam Lingkungan sekolah / madrasah, dan Pendidikan non formal [ dalam Lingkungan masyarakat ] , dimana ketiganya saling bersinergi dalam mewujudkan tujuan pendidikan yaitu mendayagunakan fisik dan non fisik manusia agar menjadi manusia selayaknya manusia.

Dalam pendidikan kita mendapat proses meniru, karena adanya proses meniru inilah maka hendaknya dan harusnya pendidikan memberikan segala hal yang baik dan sedapat mungkin kesalahan dalam meniru hendaknya dijauhkan (Shadily, 1999: 146 ). Hal ini berarti apa yang ditransferkan oleh guru semaksimal mungkin sama dengan yang diterima oleh siswa, walaupun kita tahu juga bahwa siswa tidak hanya belajar dari guru tetapi juga dari contoh-contoh yang tercantum dalam buku yang berisi tentang kehidupan pemimpin, ahli pikir, dan sebagainya diuraikan (Shadily, 1999: 147 ). Dan media massa dikatakan sebagai agen sosislisasi yang bersifat searah dan seringkali mengandung nilai-nilai bermuatan terbalik dengan nilai-nilai konformitas yang diajarkan oleh guru. Maka kita harus dapat secara selektif dan cerdas dalam mengkonsumsi suatu media massa.

Ketika secara global muncul pandemi Covid-19, maka seluruh aspek kehidupan di masyarakat terkena dampaknya, salah satunya dunia pendidkan. Pemerintah mewajibkan semua kegiatan dilakukan dari rumah, sehingga siswa dan guru tidak bisa lagi melaksanakan proses pembelajaran secara langsung, tetapi dilakukan melalui media / perantara yang dikenal dengan istilah daring yaitu memanfaatkan aplikasi seperti Google Classroom, Zoom, Youtube, Whats App, Facebook, E-Learning, email, dan sebagainya. Siswa dan guru beradaptasi dengan situasi yang ada, sehingga harapannya menjadi lebih mahir dalam memanfaatkan teknologi (melek teknologi ). Semua serba canggih, pembelajaran di Indonesia di masa Covid-19 mau tidak

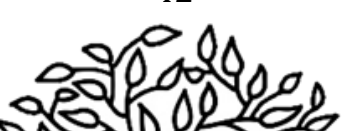


mau ikut dalam arus globalisasi dengan dominasi teknologi yang dikatakan sebagai era digital.

Tetapi disatu sisi lain dari pembelajaran daring ada suatu permasalahan, yaitu bagaimana membentuk atau mempertahankan karakter siswa yang sudah ada sebelum pandemi Covid-19. Jelas ini menjadi suatu tantangan yang cukup berat jika dilakukan oleh pihak guru. Secara sadar maupun tidak sadar, Guru adalah sebagai pendidik karakter. Perilaku dan tindakan guru dalam melaksanakan tugas-tugas di lingkungannya merupakan wahana utama pembelajrana karakter. Perilaku dan sikap guru sehari-hari praksis moral yang menyampaikan nilai khusus terhadap siswa (Koesoema, 2015:134). .Guru dapat menjadi pendidik karakter jika memiliki sikap terbuka dan kritis serta berkemauan untuk menemukan dan menegaskan kembali nilai-nilai yang diyakininya selama ini. Dan esensi utama dari pendidikan karakter adalah mengandalkan kepercayaan bahwa setiap orang bisa berubah, dan setiap orang bisa menghayati nilai-nilai moral dan kemanusiaan yang diyakininya benar dan melaksanakannya di dalam hidup. Guru sebagai pendidik karakter ditunjukkan dalam pembentukan diri. (Koesoema, 2015:156). Apakah guru sebagai pendidik karakter di masa pandemi ini masih bisa dilakukan? Memang tidak mudah, tidak berarti tidak bisa.

Dalam hal ini berkaitan dengan bagaimana pembelajaran daring dapat mencetak karakter sosial siswa. Hal ini dianggap penting karena ketika seluruh bangsa Indonesia memasuki era globalisasi bidang teknologi / era digital, maka jati diri bangsa Indonesia sebagai bangsa dengan tingkat solidaritas sosial yang tinggi, harus tetap dipertahankan. Individualisme sebagai salah satu unsur dalam paham liberalisme perlu dicounter. Sebab adanya paham Liberalisme akan memunculkan berbagai paham turunan, seperti hedonisme, materialisme, sekulerisme, ateisme, konsumerisme, dan sebagainya.

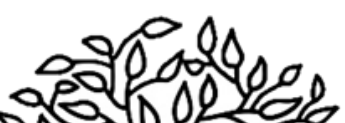


Pembelajaran secara daring di masa pandemi yang berlangsung dari pertengahan Bulan Maret sampai berakhirnya semester Genap (kurang lebih 3 bulan ), praktis tidak ada pembelajran tatap muka di lingkungan sekolah / madrasah. Disinilah perlu adanya sinergi antar lingkungan pendidikan yang sudah disinggung pada bagian sebelumnya berkaitan dengan tri pusat pendidikan, yaitu lingkungan keluarga, sekolah, dan masyarakat. Dengan tetap memperhatikan protokol kesehatan untuk melakukan social distancing maupun phisical distancing. Upaya yang bisa dilakukan guru adalah koordinasi dengan orang tua siswa melalui berbagai media komunikasi, baik visual, audio, maupun audio visual. Utamanya Handphone yang sebagian besar masyarakat Indonesia sudah memilikinya walaupun ada yang model lama dan baru / Android. Guru dapat menyampaikan kepada orang tua siswa melalui komunikasi sekunder secara langsung atau komunikasi sekunder tidak langsung, disesuaikan dengan kondisi situasi pada masing-masing orang tua siswa. Komunikasi agar siswa tetap menjalankan pembiasaan yang ada serta tetap menjalin silaturahmi / berinteraksi minimal dengan anggota keluarga, jadi tidak hanya fokus pada tugas akademik.

Guru dapat memberikan tugas pembentukan karakter sosial melalui tayangan televisi bahkan kerjasama dengan stasiun radio setempat jika daerah tempat tinggal siswa benar-benar dalam batas minimal / tidak ada akses TV atau internet. Dan untuk situasi yang paling buruk, guru dapat bekerja sama dengan aparat di lingkungan dusun setempat. Disini guru mengupayakan berbagai cara agar siswa di masa pandemi Covid-19 dapat belajar secara akademik/ pengetahuan, ketrampilan, dan pembentukan karakter juga berjalan beriringan. Dari sinilah akan berkesinambungan dengan adanya Guru Penggerak. Dan yang penting untuk disampaikan disini bahwa berhasil tidaknya proses pendidikan memang menjadi tanggung jawab bersama antara orang tua, pemerintah / sekolah, dan masyarakat

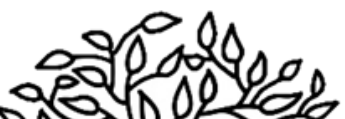


(Purwito,1996:177). Dan upaya-upaya yang dilakukan oleh guru penggerak / bersinergi dengan orang tua dan masyarakat perlu adanya saling mendukung. Perlu dicoba, dan pastikan adanya keyakinan pada semua pihak bahwa di setiap kesulitan pasti akan ada suatu kemudahan.

Mudah-mudahan pandemi Covid-19 segera berakhir, siswa dan guru dapat melakukakan komunikasi primer, sehingga harapan para pendiri negara Indonesia terhadap generasi milenial saat ini yang disebut sebagai Genearasi Emas dapat benar-benar menjadi pemimpin yang beriptek dan berimtaq di Indonesia Emas Tahun 2045 dengan tetap berpijak pada jati diri bangsa Indonesia.

\section{DAFTAR PUSTAKA}

Koesoema Doni. 2015. Pendidik Karakter di Zaman Keblinger: Mengembangkan Visi Guru Sebagai Pelaku Perubahan dan Pendidik Karakter, Jakarta: PT. Grasindo

Purwito, Edy, Drs. 1996. Sosiologi. Surakarta: Widya Duta Shadily, Hasan. 1999. Sosiologi Untuk Masyarakat Indonesia. Jakarta: Rineka Cipta 
| Upaya Guru Membentuk Karakter Sosial Siswa dalam...

46

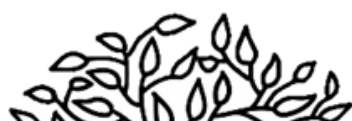




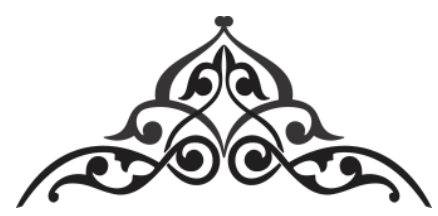

\title{
KONTRIBUSI KEMATANGAN EMOSIONAL DAN OPTIMISME DALAM PEMBELAJARAN DI ERA
} NEW NORMAL

\author{
Delsylia Tresnawaty Ufi, M.Si ${ }^{7}$ \\ Institut Agama Kristen Negeri (IAKN) Kupang
}

"Kematangan emosional, optimisme dan semangat belajar yang tinggi akan mempengaruhi usaha seseorang untuk mewujudkan masa depan yang lebih baik"

$\mathrm{P}$ erilaku manusia mempengaruhi efektifitas dan efesiensi diri untuk mencapai keberhasilan hidup. Keberhasilan hidup dapat tercapai jika manusia dapat mengelola hidupnya dengan baik, sehingga tujuan-tujuan hidupnya tercapai. Pengelolaan hidup ini tekait dengan kematangan emosional. Kematangan emosi dapat menjadi sumber energi yang membuat seseorang sanggup melakukan apa saja secara tepat. Kematangan emosi terkait dengan kontrol emosi. Menurut Muawanah dan Pratikto (2012) kontrol emosi adalah belajar mengekspresikan emosi dengan cara-cara yang dapat diterima atau disetujui oleh kelompok sosial dan pada saat yang sama dapat memberi kepuasan yang maksimum dan mengurangi gangguan ketidakseimbangan.

7 Delsylia Tresnawaty Ufi lahir di Kupang, 28 Desember 1985. Penulls merupakan Dosen Institut Agama Kristen Negeri Kupang. dalam bidang ilmu Psikologi. Penulis menyelesaikan gelar Magister Sains Psikologi di Universitas Kristen Satya Wacana tahun 2012. 
| Kontribusi Kematangan Emosional dan Optimisme...

Kematangan emosional seseorang mampu tercapai bila bertindak sesuai harapan masyarakat, mampu memanfaatkan mentalnya secara tepat, memahami diri sendiri dan tidak mudah berubah-ubah emosinya. Oleh karena itu, kematangan emosional adalah kemampuan menerima hal-hal negatif dari lingkungan tanpa membalasnya dengan sikap negatif, melainkan dengan kebijakan (Martin dalam Sinaga, 2016). Kematangan emosi memiliki beberapa aspek, yaitu dapat menerima keadaan dirinya maupun orang lain seperti apa adanya, tidak impulsif, dapat mengontrol emosi dan ekspresi emosinya dengan baik, berpikir secara objektif dan mempunyai rasa tanggung jawab (Walgito, dalam Kusyairy, 2015). Dengan demikian seseorang dikatakan mampu mencapai kematangan emosi apabila bertindak sesuai dengan harapan masyarakat, mampu memanfaatkan mentalnya secara tepat, memahami diri sendiri. Kematangan emosi dapat menghantar seseorang dalam mencapai tujuan dan keberhasilan hidupnya, karena ia mampu mengelola hidupnya di tengah-tengah situasi hidup bersosial.

Hidup bersosial salah satunya adalah dalam kegiatan pendidikan, sebab ada pola interaksi antar individu yang satu dengan individu yang lainnya. Proses sosial yang terjadi dalam perkembangan pribadi ketika masing-masing orang membangun pengetahuan bersama. Dengan demikian, dalam proses pembelajaran pendidikan ada hubungan emosional pada saat pembelajaran berlangsung (Fauziah, 2015). Di katakan demikian, karena peserta didik dengan kematangan emosional dapat mengendalikan perilaku belajarnya. Peserta didik yang mempunyai kematangan emosional yang tinggi mempunyai tujuan yang konstruktif, sehingga dapat memotivasi dirinya untuk belajar. Sebagaimana yang diungkapkan oleh Goleman (dalam Luthans, 2006) bahwa

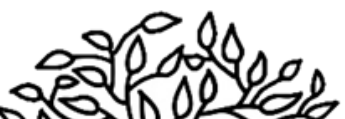


seseorang dengan memiliki karakter kematangan emosional yang luas memampukannya dalam memotivasi diri untuk bertahan dalam menghadapi frustasi, untuk mengendalikan perasaan, untuk menjaga suasana hati, untuk menjaga distress dari kemampuan untuk berpikir.

Adapun kematangan emosi yang dimiliki oleh seseorang bermanfaat untuk (Salovey dan Mayer, dalam Alam, 2009):

1. Membantu menghasilkan beberapa rencana masa depan (perencanaan fleksibel). Dalam hal ini kematangan emosi menuntun seorang pendidik untuk bekerja dalam tugas dan tanggung jawab secara prefosional, fokus dan terarah dalam perencanaan pembelajaran pendidikan serta mendapatkan hasil sebagaimana yang dirancangkan. Demikian juga dengan peserta didik mampu untuk mencapai keberhasilan belajar untuk masa depannya.

2. Meningkatkan proses pengambilan keputusan karena emosi yang lebih baik dalam memahami seseorang. Kematangan emosi, dapat membuat seorang pendidik memahami karakter peserta didiknya dengan segala permasalahan pendidikannya. Permasalahan dalam diri individu peserta didik dapat diatasi tanpa mengabaikan kewajibannya, terlebih untuk mencapai tujuan belajar.

3. Reaksi (berpikir kreatif). Seseorang dengan kematangan emosi yang dimiliki dapat membuatnya mengendalikan diri dengan emosi-emosi yang menyertainya sehingga berpikir positif untuk menghasilkan proses belajar yang baik.

4. Proses kognitif seperti kreativitas di satu sisi dan ketepatan waktu pada sisi lain (mood mengarah ke perhatian). Pentingnya kematangan emosi berguna

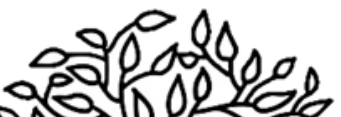


| Kontribusi Kematangan Emosional dan Optimisme...

dalam proses kognitif untuk menghasilkan pembelajaran yang berkualitas. Selain itu, seseorang dengan kematangan emosionalnya dapat mengolah proses berpikir kognitif untuk menciptakan daya kreatif belajar. Seseorang dengan daya berpikir kreatifnya tidak akan terpengaruh dengan situasi yang kurang mendukung sekalipun, atau lingkungan belajar yang tidak kondusif dan justru akan memiliki perhatian untuk penyelesaian-penyelesaian tugas berdasarkan waktu yang ditetapkan.

5. Meningkatkan ketekunan tentang tugas-tugas yang menantang (memotivasi emosi). Kematangan emosional mempengaruhi seseorang dalam perilaku belajar yang positif. Di mana kematangan emosional menghasilkan ketekunan belajar, dan kematangan emosi juga berdampak positif pada kegiatan belajar dalam mengerjakan tugas-tugas, baik yang dianggap ringan maupun tugas-tugas yang dianggap berat.

Seseorang dengan kematangan emosional berguna bagi kegiatan belajarnya. Kegiatan belajar merupakan kegiatan penting yang dilakukan peserta didik. Kegiatan belajar itu sendiri dapat terjadi dimana saja dan kapan saja. Kegiatan belajar yang dilakukan peserta didik mampu meningkatkan prestasinya dalam belajar. Prestasi adalah kemampuan seseorang yang dapat diperoleh setelah hasil belajar. Dengan demikian, peserta didik yang mempunyai kematangan emosional yang tinggi akan menjadi pribadi yang mandiri, percaya diri dan mampu mengikuti serta melaksanakan proses pembelajaran secara maksimal (Fauziah, 2015). Hal ini terkait dengan sikap optimisme. 
Sikap optimisme pada peserta didik bermanfaat dalam proses pembelajaran. Seligman (dalam Kurniati dan Fakhruddin, 2018) mengatakan optimisme berperan penting terhadap kesuksesan seseorang dalam pekerjaan, sekolah, kesehatan, dan juga relasi sosial. Studi yang dilakukan oleh Seligman selama dua puluh tahun dengan melibatkan lebih dari lima ratus ribu orang dewasa dan anak-anak menunjukkan bahwa orang pesimis memiliki prestasi rendah atau kurang di sekolah maupun di pekerjaan, dibandingkan dengan orang yang optimis. Hal ini menunjukkan bahwa optimisme bermanfaat untuk memotivasi seseorang dalam berbagai segi kehidupan.

Optimisme yang ada dalam diri setiap orang menghadirkan kepercayaan diri dalam pekerjaannya termasuk dalam kegiatan belajar. Optimisme dan semangat yang tinggi mempengaruhi usaha seseorang untuk mewujudkan masa depan yang lebih baik (Nurtjahyanti dan Ratnaningsih dalam Kurniati dan Fakhruddin, 2018). Masa depan dapat tercapai oleh seorang peserta didik dengan memandang masalah-masalah belajarnya sebagai sesuatu yang mesti dipecahkan atau diselesaikan bukan diabaikan. Oleh karena itu, peserta didik dengan optimisme yang dimiliki cenderung lebih sehat dan memiliki harapan yang positif, serta lebih matang emosinya yang membuatnya tidak mudah berputus asa, tidak merasa bodoh dan tidak mudah mengalami depresi (Noordjanah, 2013). Belsky (dalam Ghufron dan Risnawita, 2010) berpendapat bahwa optimisme berdampak pada keberhasilan karena sikap optimisme menjadikan seseorang memiliki energi tinggi, dan bekerja keras untuk melakukan hal yang penting. Hal inilah yang penting bagi seorang peserta didik, bahwa dengan optimisme

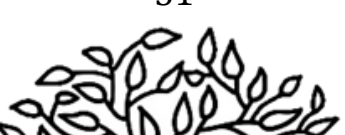


| Kontribusi Kematangan Emosional dan Optimisme...

dapat menyelesaikan kewajibannya dengan baik tanpa takut pada kegagalan yang akan dihadapi.

Ciri-ciri optimisme dalam diri setiap individu (Rizki, 2013) adalah:

Pertama, selalu berfikir positif. Peserta didik selalu mempunyai harapan bahwa dia bisa mengikuti proses belajar dan yakin akan berhasil dalam mengerjakan tugas-tugas. Kedua, memiliki kepercayaan diri yang tinggi. Peserta didik mempunyai rasa percaya diri yang tinggi ketika mengerjakan soal-soal ujian yang diberikan. Rasa percaya diri yang tinggi juga bahwa akan mendapatkan hasil yang terbaik. Ketiga, yakin pada kemampuan yang dimiliki. Peserta didik merasa mampu untuk mengerjakan tugas-tugas secara mandiri. Mereka merasa yakin terhadap kemampuan yang dimilikinya, serta yakin akan mendapatkan hasil yang memuaskan dengan kemampuan yang dimilikinya. Keempat, tidak takut akan kegagalan. Peserta didik yang optimis pasti berani menghadapi tantangan yang akan dihadapi tanpa adanya rasa takut untuk mengalami suatu kegagalan, karena mereka yang optimis pasti akan selalu berfikir bahwa dia akan berhasil menghadapi suatu tantangan. Kelima, berusaha meningkatkan kekuatan yang dimiliki. Peserta didik yang optimis pasti akan berusaha meningkatkan kemampuan yang dimilikinya karena yakin dengan kemampuannya sendiri. Keenam, tidak mudah stress. Peserta didik yang optimis mampu menghadapi tekanan-tekanan sehingga tidak mudah mengalami stress ketika menghadapi suatu tantangan dalam proses belajarnya.

Era new normal ini membawa perubahan dalam dunia pendidikan, terkhususnya dalam hal pembelajaran. Peserta didik yang mengikuti proses pembelajaran mau tidak mau harus mengikuti sistem belajar yang baru. Belajar tidak lagi

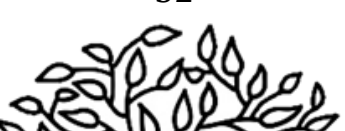


dalam bentuk konvensional, namun dengan berbasis internet atau pembelajaran daring. Jika dimungkinkan pada akhirnya pembelajaran dengan ketentuan tertentu menghendaki pertemuan-pertemuan di kelas, namun,dengan tetap memperhatikan protokol kesehatan, maka semua elemen pendidikan terkhususnya pendidik dan peserta didik harus dapat berpikir positif serta memiliki kematangan emosional dan optimisme dalam belajar. Pengaturan dan pengelolaan emosi yang positif dapat menghantar pada pencapaian tujuan dari proses pembelajaran itu sendiri. Hal tersebut menunjukkan bahwa pembelajaran merupakan bantuan yang diberikan pendidik agar dapat terjadi proses pemerolehan ilmu dan pengetahuan, penguasaan kemahiran, pembentukkan sikap dan kepercayaan pada peserta didik (Kadeni,tt). Sebagaimana yang dijelaskan oleh Sanjaya (2008) bahwa pembelajaran merupakan proses kerja sama antara pendidik dan peserta didik dalam memanfaatkan segala potensi dan sumber yang ada. Potensi yang bersumber dari dalam diri peserta didik seperti minat, bakat, dan kemampuan dasar yang dimiliki, termasuk gaya belajar. Sedangkan, potensi yang ada di luar diri siswa seperti lingkungan, sarana, dan sumber belajar. Potensi-potensi yang dimiliki peserta didik ini sebagai upaya untuk mencapai tujuan belajar.

\section{Daftar Pustaka}

Alam, M, M. (2009). The relationships between emotional intelligence and job satisfaction: Empirical findings from higher education institution in Malaysia. Journal of Management and Social Sciences, 5 (2),124-139.

Fauziah. 2015. Hubungan Kecerdasan Emosional Dengan Prestasi Belajar Mahasiswa Semester II Bimbingan

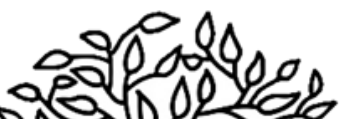


| Kontribusi Kematangan Emosional dan Optimisme...

Konseling UIN AR-RANIRY. Jurnal Ilmiah Edukasi. Vol 1, Nomor 1

Ghufron, M.N., dan Rini Risnawita. 2010. Teori-teori Psikologi.Yogyakarta: AR-RUZZ MEDIA.

Kadeni. Tanpa Tahun. Pentingnya Kecerdasan Emosional Dalam Pembelajaran. STKIP PGRI Blitar

Kurniati,L., dan Fakhruddin,A.U. 2018. Pengaruh Optimisme Terhadap Kemampuan Pemecahan Masalah Matematika Pada Siswa SMA. Seminar Nasional Edusainstek,Fakultas MIPA:UNIMUS.

Kusyairy, U. 2015. Hubungan Antara Kematangan Emosi dan Kepercayaan Diri Dengan Sikap Belajar Siswa Pada Mata Pelajaran Fisika Di Kelas XI IPA SMA Negeri Belopa Kab. Luwu. Jurnal Pendidikan Fisika. Vol. 3 No. 1

Luthans,F. 2006. Perilaku Organisasi. Yogyakarta:Andi

Muawanah, L.B., dan Pratikno, H.2012. Kematangan Emosi, Konsep Diri dan Kenakalan Remaja. JurnalPsikologi, Vol 7, No. 1, April 2012

Noordjanah, A. 2013. Hubungan Harga Diri dan Optimisme Dengan Motivasi Belajar Pada Siswa MAN Maguwoharjo Sleman Yogyakarta. Jurnal Psikologi Terapan dan Pendidikan,1(1)

Rizki, U.Y. 2013. Hubungan Kesiapan Belajar Dengan Optimisme Mengerjakan Ujian. Educational Psychology Jornal

Sanjaya,W. 2008. Perencanaan dan Desain Sistem Pembelajaran. Bandung: Kencana Prenada Media Group

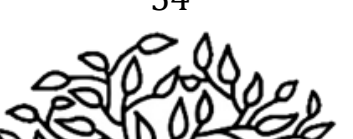




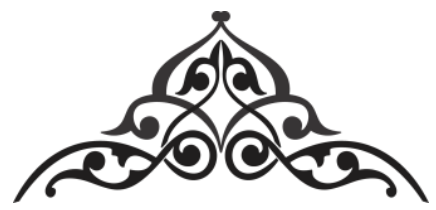

\title{
PERAN BIMBINGAN KONSELING (BK) DALAM PEMBELAJARAN DARING DI TINGKAT MADRASAH ALIYAH
}

\author{
Mita Mahda Saputri, S. Ag8 \\ MA Hidayatul Athfal - Kota Pekalongan
}

\begin{abstract}
"BK merupakan stakeholder yang memiliki peranan penting selama masa pandemi covid-19 sampai masa

New Normal. BK menjembatani dan

mengkomunikasikan berbagai kendala yang muncul sebagai dampak dari adanya pembelajaran daring (online)"
\end{abstract}

Gatuan pendidikan baik di sekolah maupun di sebuah
Madrasah tidak cukup hanya memberikan teori tentang ilmu
pengetahuan saja. Teori ilmu pengetahuan hanya berkecimpung
dalam bidang akademik dan prestasi akademik. Sehingga teori
ilmu pengetahuan belum bisa menjadi dasar berperilaku di
kehidupan masyarakat. Oleh karena itu, para siswa
membutuhkan pendidikan karakter untuk mempersiapkan diri
menjalankan kehidupan di masyarakat umum. Pendidikan

${ }_{8}$ Mita Mahda Saputri lahir di Pekalongan pada 23 April 1994, merupakan anak pertama dari dua bersaudara. Penulis menempuh pendidikan dari SD, SMP, SMK dengan jurusan teknik komputer dan jaringan (TKJ). Pada tahun 2013 memutuskan untuk masuk kuliah di Jurusan Tasawuf dan Psikoterapi IAIN Pekalongan dengan tujuan ingin mempelajari dan memperdalam tentang ilmu agama, kejiwaan, dan kehidupan. Penulis menyelesaikan progras sarjananya di tahun 2017. Kemudian, menjadi Guru BK di salah satu Madrasah Aliyah swasta di Kota Pekalongan sejak tahun 2018 hingga sekarang. 


\section{*ै| Peran Bimbingan Konseling (BK) dalam Pembelajaran Daring...}

karakter yang di dapat oleh para siswa bisa didapatkan di sekolah maupun madrasah melalui pelayanan Bimbingan Konseling (BK). Sebuah sekolah maupun madrasah membutuhkan adanya guru BK untuk memberikan pelayanan dan arahan tentang pendidikan karakter.

Pendidikan karakter yang diberikan oleh layanan BK di madrasah membantu mengembangkan potensi para siswa untuk lebih maju baik dalam bidang pengetahuan, prestasi, dan karir. Pelayanan bimbingan konseling di madrasah dalam proses pendidikan berkaitan erat dengan upaya untuk mencapai tujuan pendidikan bagi para siswa. Pelayanan BK dalam proses pendidikan tersebut merupakan salah satu upaya untuk mewujudkan manusia seutuhnya. Sebab secara fitrahnya, manusia termasuk makhluk yang senantiasa membutuhkan orang lain khususnya dalam layanan pemenuhan kebutuhan hidupnya. Para siswa juga membutuhkan layanan secara intensif dan terus menerus dari para guru supaya mereka bisa benarbenar belajar secara optimal dan nyaman tentunya.

Layanan BK yang diberikan kepada para siswa baik mengenai pendidikan karakter, pengembangan potensi, dan pengarahan karir biasanya dilakukan dengan sistem tatap muka individual maupun kelompok. Namun pada awal tahun 2020 ini, Dunia sedang mengalami pandemi covid-19 yang mengharuskan semua kalangan untuk mematuhi protokol dari pemerintah, termasuk Negara Indonesia. Adanya pandemi covid-19 ini tidak hanya berdampak pada bidang perekonomian saja. Melainkan bidang pendidikan juga mendapat dampak yang besar. Sistem pembelajaran luring terpaksa harus diganti menggunakan daring (online). Tentunya hal tersebut tidak mudah untuk dilakukan. Demikian pula dengan pelayanan BK juga harus menggunakan sistem daring. Kemudian, bagaimana peran BK dalam melaksanakan pelayanan-pelayanan tersebut dengan menggunakan daring (online)?

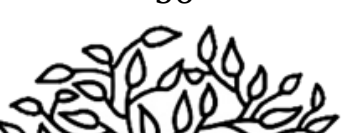


Sistem pembelajaran daring (online) yang diterapkan dalam sekolah-sekolah dengan kapasitas para siswa yang memiliki perekonomian keluarga menengah ke atas mungkin tidak mengalami kesulitan. Berbeda halnya dengan sekolah swasta yang memiliki kapasitas para siswa dengan latar belakang perekonomian keluarga menegah ke bawah. Tentunya segala fasilitas yang ada sangat terbatas. Selain fasilitas yang terbatas, semangat para siswapun mulai menurun dan tidak terkontrol. Banyak para siswa yang mengabaikan pembelajaran daring (online) dan memilih untuk mencari pekerjaan demi membantu perekonomian keluarga di masa pandemi covid-19 ini. Pembelajaran daring (online) bagi mereka hal yang kurang menarik bahkan membosankan, bagi para siswa mencari pekerjaan di masa pandemi merupakan hal yang sangat dibutuhkan.

Peran BK sangat dibutuhkan dalam sistem pembelajaran daring (online) ini. Peran BK dalam hal ini bukan lagi hanya tentang karakter maupun pengembangan potensi baik akademik maupun non akademik. Melainkan, mencari cara dan solusi untuk meningkatkan kembali semangat para siswa dalam pembelajaran daring (online). Hal demikian tentunya memerlukan kerja sama semua pihak pendidik yang ada di lingkungan madrasah. Kerjasama semua pihak pendidik di lingkungan madrasah sangat berpotensi untuk mengatasi berbagai kejenuhan dalam pembelajaran daring (online).

Cara yang dilakukan dalam pelayanan BK pada masa pandemi covid-19 juga harus mengikuti protokol pemerintah. Layanan BK yang biasanya menggunakan cara home visit atau berkunjung ke rumah para siswa untuk lebih mengenal para siswa dan keluarganya sementara ini tidak dilaksanakan. Namun pelayanan tersebut tetap berjalan meskipun tidak begitu optimal. Adapun peran BK dalam pembelajaran daring ini, antara lain:

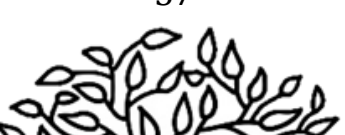


| Peran Bimbingan Konseling (BK) dalam Pembelajaran Daring...

a. Memantau segala aktifitas pembelajaran daring (online) dalam semua mapel.

b. Mengontrol keaktifan para siswa dalam pembelajaran daring (online).

c. Membuka pelayanan BK secara daring (online).

d. Memberikan kesempatan kepada para siswa untuk memberikan saran tentang pembelajaran daring (online). yang lebih menyenangkan dan sesuai dengan keadaan para siswa. Hal ini dilakukan dengan membuat angket data di google form untuk mempermudah para siswa memberikan saran.

e. Komunikasi dengan kepala madrasah/sekolah mengenai pembelajaran daring (online) yang lebih efektif dan menyenangkan.

f. Melaksanakan pembelajaran daring yang efektif dan menyenangkan bekerjasama dengan semua pihak pendidik yang ada di lingkungan madrasah.

Peran BK dalam pembelajaran daring (online) membuat pembelajaran mata pelajaran lain tetap terlaksana dan menjadikan pembelajaran daring (online) ini lebih efektif dan menyenangkan untuk para siswa. Sehingga, segala ilmu pengetahuan dapat tersampaikan dan dapat dipahami oleh para siswa. Peran BK dalam metode pembelajaran daring (online) sangat berpengaruh sekali terhadap kesuksesan siswa dalam menerima materi yang diajarkan. Meskipun tidak sepenuhnya mereka bisa menyerap dari ilmu yang disampaikan secara daring (online). Apalagi frekuensi waktu dalam pembelajaran daring (online) ini masing-masing dari para guru sangat beranekaragam media yang digunakan.

Melihat hal tersebut, tentunya secara tidak langsung para siswa juga diajak untuk memanfaatkan berbagai sarana aplikasi media sosial sebagai pembelajaran daring (online) yang dipakai

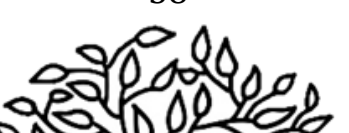


oleh para guru. Awalnya pembelajaran daring (online) sangat meresahkan dan membuat para siswa tidak bisa optimal dalam belajar. Namun secara perlahan-lahan mereka bisa menerima pembelajaran dengan sistem daring (online). Bahkan materimateri BK yang diajarkan kepada mereka sangat membantu pola pikir akan pentingnya belajar meskipun tidak harus dengan tatap muka secara langsung.

Keberadaan BK juga sangat membantu merubah karakteristik mereka yang cenderung acuh dan cuwek saat menerima materi pembelajaran. BK sebagai salah satu materi pembelajaran yang apabila diterima langsung menjadi sesuatu yang menakutkan, namun selama masa daring (online), BK justru menjadi sebuah pelajaran yang sangat disukai oleh mereka. Dengan begitu, BK mampu merubah sikap mereka yang awalnya tidak memiliki semangat belajar menjadikan mereka semangat belajar.

Peran BK dalam pembelajaran daring (online) juga membantu para siswa dalam mengontrol diri untuk senantiasa bisa bertanggung jawab atas segala tugas yang diberikan oleh guru. Pembelajaran daring (online). Sebenarnya juga memiliki sisi negatif yang bisa dirasakan oleh semua pihak, mulai dari guru, siswa, dan juga wali murid (orang tua). Sebagai seorang guru, tentunya mereka juga dituntut supaya materi pembelajaran daring (online) benar-benar bisa diterima oleh siswa. Meskipun hal itu tidaklah mudah dilakukan oleh guru saat pembelajaran daring (online) ini. Rasa cemas dan khawatir dirasakan oleh para guru selama pembelajaran daring (online). Mereka merasa bahwa materi yang disampaikan secara daring (online) ini tidak bisa sepenuhnya diterima dan dipahami secara betul oleh para siswa. Padahal mereka sudah secara totalitas menggunakan media pembelajaran daring (online) yang benarbenar bisa diterima dan diikuti oleh semua siswa.

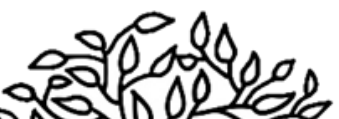




\section{1\% | Peran Bimbingan Konseling (BK) dalam Pembelajaran Daring...}

Para siswa juga tidaklah jauh beda perasaannya selama pembelajaran daring (online). Mereka merasa bahwa semua materi yang diajarkan selama daring (online) tidak bisa sepenuhnya terserap dan diterima dengan baik. Berbagai kendala mereka alami mulai dari sinyal yang tidak baik, durasi waktu yang terlalu cepat dan terkadang fleksibel serta penjelasan materi tidak sampai tuntas. Mereka juga memiliki kekhawatiran yang cukup besar dari hasil pembelajaran daring (online) ini. Sebagian besar dari mereka takut kalau nilai akhir dari belajar selama masa daring (online) membuat nilai mereka menurun dan tidak sesuai dengan harapan.

Orang tua mereka juga mengalami hal sama sebagaimana yang dirasakan oleh para guru dan anak-anak mereka. Mereka yang sudah berusaha memberikan segala fasilitas kepada anaknya supaya tetap bisa belajar secara daring (online) juga khawatir kalau anak-anak mereka itu tidak bisa menerima ilmu yang diajarkan para guru dengan baik. Karena berbagai kendala yang dialami oleh anak-anak mereka juga dirasakan dan diketahui oleh mereka. Mereka juga sebagian besar memperhatikan proses pembelajaran daring (online) yang selama ini dialami oleh anak-anak mereka. Bahkan mereka juga khawatir kalau hasil akhir dari pembelajaran daring (online) yang diterima oleh anak-anak mereka berdampak pada nilai yang tidak baik atau bahkan membuat anak-anak mereka tidak naik kelas atau tidak lulus.

Berbagai kendala dan problem yang terjadi selama masa pembelajaran daring (online) itu menjadikan peran BK semakin dibutuhkan dan harus benar-benar bisa berhasil. BK akhirnya selama masa pembelajaran daring (online) ini tidak hanya sebatas memberikan materi-materi yang memberatkan para siswa, tapi justru BK menjadi pusat pelayanan dan pusat solusi bagi para siswa untuk nyaman belajar dengan sistem daring (online). Keberadaan BK diharapkan bisa menjadi layanan

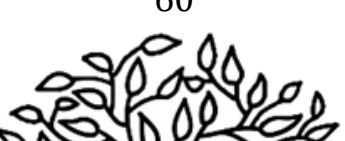


komunikasi bagi para siswa dengan para guru yang mengalami kesulitan dan hambatan dalam pembelajaran daring (online).

BK dalam masa daring (online) mengajarkan siswa untuk lebih bertanggung jawab terhadap kewajiban mereka yaitu belajar. Walalupun dalam masa pandemi ini yang membatasi mereka bertatap muka langsung dengan guru-guru seperti biasanya, namun mereka tetap memiliki kewajiban yang harus mereka laksanakan yaitu belajar. Dengan demikian, BK dapat menumbuhkan rasa tanggung jawab dan semangat dalam melaksanakan pembelajaran daring (online). Sehingga, siswa tetap mendapatkan ilmu pengetahuan secara efektif dan jelas.

Selama pembelajaran daring (online), BK senantiasa mengajak para siswa untuk tetap beraktifitas dengan mengikuti protokol kesehatan pencegahan dan penularan covid-19. Peran serta BK dalam mencegah penularan dan penyebaran covid-19 di lingkungan sekolah juga selalu disampaikan kepada para siswa selama pembelajaran daring (online). Bahkan peran serta BK dalam hal tersebut sangat diapresiasi sekali oleh para guru, para siswa dan para wali murid (orang tua). Secara tidak langsung, BK merupakan stakeholder yang memeliki peranan penting bagi berjalannya pembelajaran daring (online) selama masa pandemi covid-19 sampai masa New Normal. Bisa dikatakan pula bahwa pembelajaran daring (online) bisa berjalan secara lancar dan sesuai harapan, apabila peran serta dan keterlibatan BK di setiap sekolah benar-benar dioptimalkan. Karena BK mampu menjembatani antara guru, siswa dan wali murid (orang tua) dalam menegaskan dan mengkomunikasikan berbagai kendala dan masalah yang muncul sebagai dampak dari adanya pembelajaran daring (online).

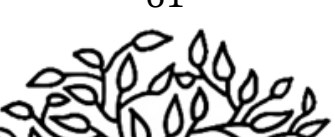


| Peran Bimbingan Konseling (BK) dalam Pembelajaran Daring...

62 


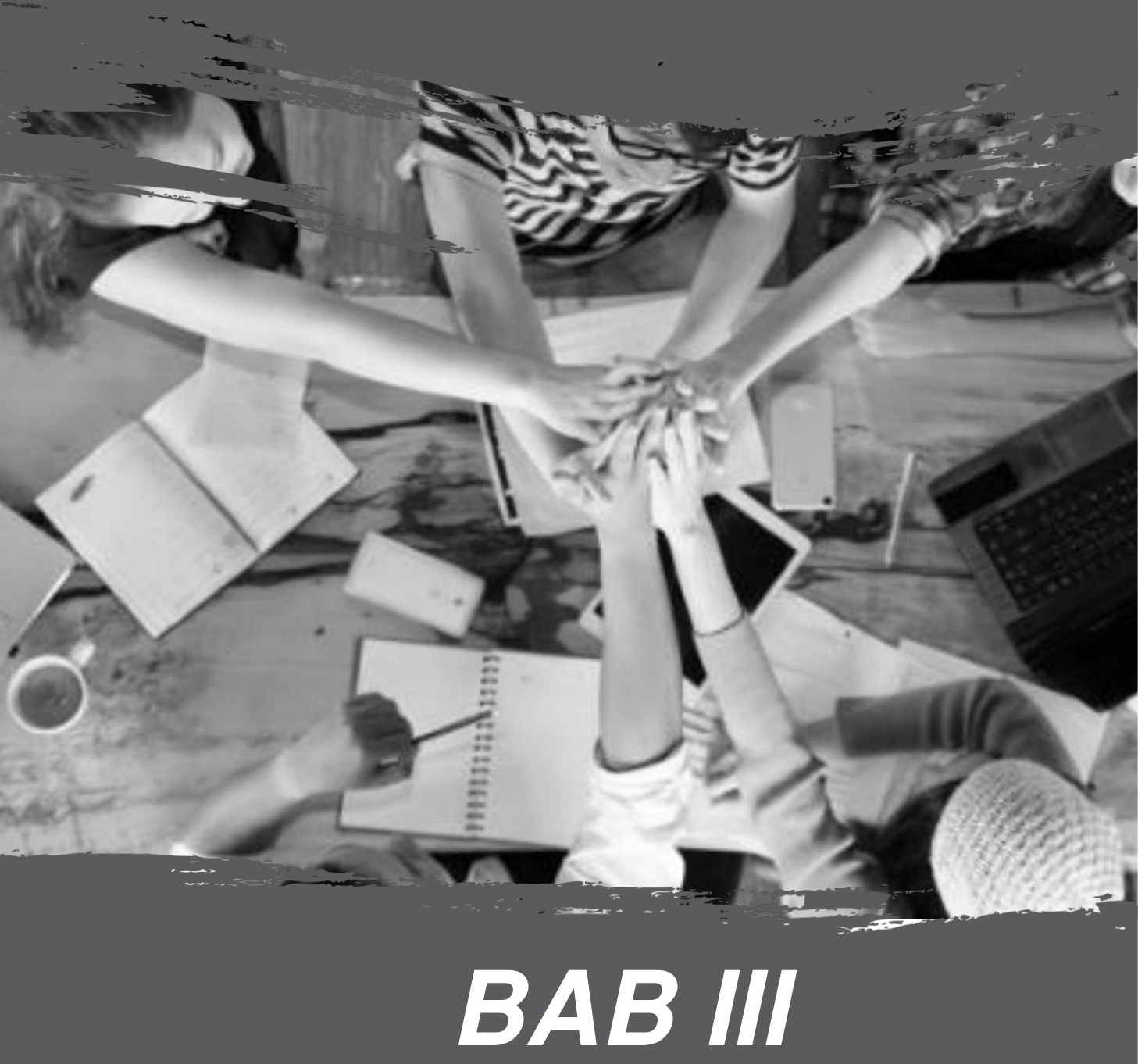

\section{DINAMIKA IMPLEMENTASI PEMBELAJARAN DARING}




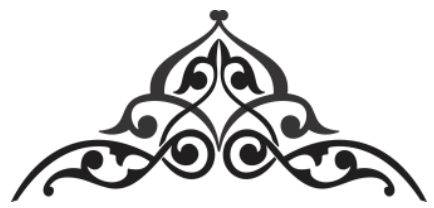

\title{
DILEMA PERGURUAN TINGGI DALAM MENERAPKAN PEMBELAJARAN DARING DI MASA PANDEMI COVID-19
}

\author{
Suwantoro, M.Pd. ${ }^{9}$ \\ Dosen Fakultas Tarbiyah IAIN Madura
}

"Perguruan tinggi harus aktif, sensitif pada perubahan, kreatif dalam mewujudkan kegiatan pembelajaran daring ini demi keberlangsungan pembelajaran"

$\mathrm{M}$ unculnya virus corona atau covid-19 dalam kehidupan manusia sungguh sangat memberikan dampak yang luar biasa. Hampir semua aspek dalam kehidupan masyarakat terkenak imbasnya. Mulai dari aspek kesehatan, ekonomi, politik, sosial, budaya, agama, dan termasuk aspek pendidikan juga inklut di dalamnya. Perubahan ini merupakan dinamika baru sekaligus menjadi kajian yang sangat serius dengan membutuhkan banyak pasrtisipasi dari semua elemen masyarakat khususnya pemerintah. Baik pemerintah daerah ataupun pemerintah pusat yang secara kedudukan memiliki posisi strategis dalam melahirkan kebijakan untuk memutus

${ }^{9}$ Suwantoro lahir di Sumenep, 05 Januari 1991, penulis merupakan Dosen Fakultas Tarbiyah IAIN Madura dalam bidang ilmu Pendidikan Agama Islam, penulis menyelesaikan gelar Sarjana Pendidikan Agama Islam di STAIN Pamekasan (2003), dan gelar Magister Pendidikan Agama Islam diselesaikan di UINSA Surabaya Program Studi Pendidikan Agama Islam (20015) 


\section{| Dilema Perguruan Tinggi dalam Menerapkan Pembelajaran...}

mata rantai penyebaran covid-19 yang sampai saat ini tercatat sudah memakan jutaan korban.

Sebagai ikhtiyar dari upaya memutus mata rantai penyebaran covid-19, akhirnya pemerintah melalui kementerian kesehatan merumuskan protocol kesehatan yang bisa dilakukan oleh semua orang untuk mencegah penularan virus ini. Diantaranya adalah dengan penerapan jaga jarak atau social distancing yang kemudian istilah tersebut berubah menajdi phsysical distancing. Akibatnya, semua aktifitas dan rutinitas masyarakat di berbagai bidang harus dilakukan dengan menjaga jarak aman. Bahkan, demi keselamatan dan keseriusan dalam mengatasi virus yang mematikan ini, semua aktifitas atau kegiatan yang melibatkan banyak massa harus diberhentikan atau paling tidak ditunda hingga menunggu keadaan dan kondisi betul-betul pulih kembali.

Dengan lahirnya kebijakan tersebut, hal ini juga akan berlaku dalam dunia pendidikan. Artinya, ketika aktifitas dari banyak orang yang berpotensi terjadinya penularan virus covid19 diberhentikan atau ditunda, maka aktifitas pembelajaran di lembaga pendidikan mulai dari sekolah tingkat dasar (SD) sampai pada level pendidikan di perguruan tinggi untuk sementara waktu terpaksa juga harus "diberhentikan" dengan alasan yang sama, keselamatan tetap menjadi prioritas utama.

Pemberhentian proses pembelajaran pada setiap lembaga pendidikan, tentu saja tidak boleh diartikan sebagai momentum untuk meliburkan diri bagi semua kalangan, baik dari unsur peserta didik (siswa ataupun mahasiswa) ataupun unsur tenaga pendidik (guru atau dosen). Justru, demi membangun continuitas belajar peserta didik yang sudah terprogram dan demi tugas mulia guru atau dosen sebagai tenaga pendidik, pembelajaran harus tetap dilaksanakan meskipun di tengah polemik pandemi.

Menyikapi fenomena ini, akhirnya mas mentri pendidikan dan kebudayaan merespon cepat dengan 
mengeluarkan Surat Edaran (SE) nomor 4 tahun 2020 tentang pelaksanaan kebijakan pendidikan dalam masa darurat covid 19. Point penting yang dapat kita tangkap dari SE tersebut adalah bahwa selama bangsa ini masih berada dalam problem pandemi ini, sekolah tidak lagi dijadikan sebagai satu-satunya tempat belajar yang terprogram. Semua aktifitas pendidikan (pembelajaran) harus dilakukan di rumah masing-masing tanpa mengurangi hak belajar peserta didik dan tanggung jawab mengajar pendidik.

Masa pandemi covid-19 ini, merupakan suatu masa dimana semua aktifitas menjadi terbatas, semua rencana yang sudah terprogram tidak bisa dijalankan. Bahkan sebagai satusatunya pilihan terbaik kita di masa ini adalah sesegera mungkin melakukan langkah adaptasi dengan lingkungan sekitar. Salah satu bukti nyata dari proses adaptasi akibat pandemi ini adalah maraknya model pembelajaran daring yang dilakukan diberbagai lembaga pendidikan. Sebagai satu-satunya model yang dijadikan alaternatif, maka keberadaannya harus bisa memberikan solusi dari setiap problematika pembelajaran yang muncul. Tidak hanya dalam konteks tersampainya materi kepada peserta didik, tapi juga kualitas atau mutu pembelajaran yang dilaksanakan dengan menggunakan model ini harus menjadi prioritasnya.

Sadar ataupun tidak, kita semua pasti akan mengakui bahwa virus covid-19 tidak hanya datang dengan membawa kepanikan dan ancaman kematian saja. Tetapi, ia (covid-19) juga menjadi penggerak yang telah berhasil menggiring perubahan besar dalam kehidupan manusia. Dari sekian banyak perubahan tersebut, satu diantaranya adalah beralihnya pembelajaran konvensional menjadi pembelajaran daring dengan memanfaatkan jasa tekhnologi, baik berupa WA Group, Google Classroom, Zoom, Google Meet, live streaming on youtube, dan aplikasi lain yang bisa dijadikan sarana pembelajaran dengan tanpa harus bertatap muka.

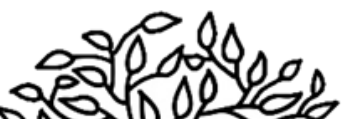


| Dilema Perguruan Tinggi dalam Menerapkan Pembelajaran...

Sebenarnya, Penerapan model pembelajaran daring dengan pemanfaatan jasa tekhnologi tentu saja bukan hal baru dalam dunia pendidikan kita. Apa lagi dalam kehidupan pendidikan perguruan tinggi yang secara kedudukannya sangat berpotensi untuk melakukan model pembelajaran ini. Jika kita telusuri kembali, secara konseptual, akan banyak ditemukan dalam berbagai literatur yang megupas tuntas perihal pembelajaran daring mulai dari pendidikan tingkat dasar hingga pendidikan di perguruan tinggi. Bahkan, lembaga perguruan tinggi yang lengkap secara infrastruktur dan memadai dari sisi sumber daya manusia (SDM) nya sudah pernah bahkan sering melakukannya sebagai bentuk variasi pembelajaran yang menyesuaikan dengan perkembangan zaman.

Meskipun demikian adanya, pembelajaan daring saat ini menjadi isu terhangat dalam dunia pendidikan seiring dengan maraknya penyebaran virus covid-19. Bahkan dalam setiap kegiatan-kegiatan webinarpun yang diselenggarakan oleh perguruan tinggi, pembelajaran daring kerap sekali menjadi topik perbincangannya baik dari sudut positif dan negatifnya, dari sisi problem dan solusinya atau dari aspek peluang dan tantangannya.

Selanjutnya, di atas itu semua penerapan pembelajaran daring tidaklah semudah yang kita bayangkan. Secara universal, penulis berasumsi ada tiga hal yang menjadi pusat perhatian semua lembaga pendidikan ketika ingin menerapkan model pembelajaran ini. Pertama adalah infrastruktur yang lengkap dan memadai sebagai modal utama untuk melaksanakan model pembelajaran ini. Kedua adalah penguasaan SDM (pendidik) terhadap penggunaan alat tekhnologi yang dijadikan sebagai jembatan penghubung antara pendidik dengan peserta didiknya dalam keberlangsungan proses pembelajaran. Dan yang ketiga adalah kesiapan peserta didik dalam melakukan adaptasi belajar dengan menggunakan pendekatan model ini.

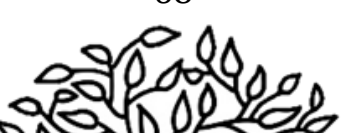


Penerapan pembelajaran daring di era pandemi, khususnya pada level pendidikan tinggi, sangat berbeda sekali dengan penerapan di luar pandemi yang hanya bertumpu pada tuntutan era digitalisasi. Dari sisi pelaksanaan misalnya,pembelajaran daring di luar pandemi akan terlihat terencana dan terkonsep secara matang. Sehingga semuanya akan tampak betul-betul siap melakukan pembelajaran model daring. Beda halnya dengan penerapan pembelajaran daring dalam konteks pandemi. semuanya pembelajaran daring yang dilakukan saat ini sebagai upaya pertanggung jawaban instansi kepada stakeholdermya akan terlihat tanpa persiapan. Baik dari unsur SDM, infrastruktur, standarisasi, tolok ukur keberhasilan dan lain sebagainya. Akibatnya, sebagian besar dari lembaga perguruan tinggi dihadapkan pada problem sebagai akibat dari pelaksanaan model pembelajaran yang "dipaksakan".

Sebagai penguat dari pernyataan tersebut, mari kita mencoba menelaah lebih dalam bagaimana realitas lembaga pendidikan kita saat ini. Semua perguruan tinggi harus betulbetul mencari cara mensiasati pelaksanaan pembelajaran agar tetap berlangsng di tengah pandemi ini. Meskipun hasilnya tetap kembali pada alternatif yang sama yaitu pembelajaran daring.

Penulis meyakini bahwa semua lembaga pendidikan termasuk di dalamnya adalah perguruan tinggi, melaksanakan kegitan pembelajaran secara daring di tengah pandemi covid-19 akan selalu menyesuaikan dengan potensi dan kekuatan intern masing-masing lembaga dengan tetap mempertimbangkan continuitas pembelajaran sekaligus juga memperhatikan kualitas pembelajaran.

Kendatipun demikian adanya, lagi-lagi akan muncul beberapa persoalan yang selalu mengirinya sebagai dampak dari alternatif model ini. Bahkan, pada gilirannyapun, segenap persoalan yang ada akan mengantarkan perguruan tinggi pada suatu kondisi yang dilematis. Dimana, ia (PT) harus tetap

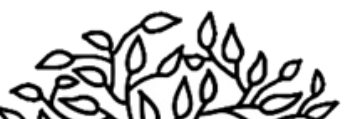




\section{| Dilema Perguruan Tinggi dalam Menerapkan Pembelajaran...}

melaksankan aktifitas pembelajarannya dengan cara ini, namun pada sisi yang lain lembaga dengan segenap unsurnya masih belum siap dengan perubahan ini. Akhirnya, karena secara esensial perguruan tinggi sangat berbeda dengan lembaga pendidikan lainnya, maka terjadilah berbagai macam kritikan sekaligus aksi dari mahasiswa terkait pembelajaran daring ini yang terkesan memberatkan dan prosesnyapun dianggap kurang maksimal.

Oleh sebab itu, pembelajaran ditengah pandemi ini tentu akan menjadi pekerjaan berat dari masing-masing unsur di setiap lembaga pendidikan khususnya perguruan tinggi. Disamping tiga hal yang perlu dipersiapkan sebagaimana penulis sampaikan di atas, mereka juga dituntut harus aktif, sensitif pada perubahan, dan harus kreatif dalam mewujudkan kegiatan pembelajaran daring ini demi keberlangsungan pembelajaran.

Akhirnya, Kita semua harus menyadari bahwa hadirnya covid-19 di tengah-tengah kita harus jadikan momentum untuk merubah diri menajdi lebih baik. kita pun tidak boleh ikut larut dalam suasana pandemi yang endingnya hanya menambah masalah dalam menjalankan kewajiban sebagai pendidik atau peserta didik. Mari kita hadapi bersama, lakukan semuanya dengan kemampuan dan kondisi saat ini dengan segala kelebihan dan peluang yang ada. Siasati segala bentuk kekurangan dan keterbatasan demi terwujudnya proses pembelajaran yang merupakan ruh dari pendidikan. Wallaua'lam.....

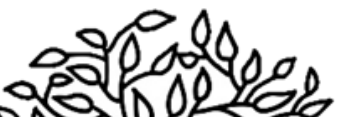




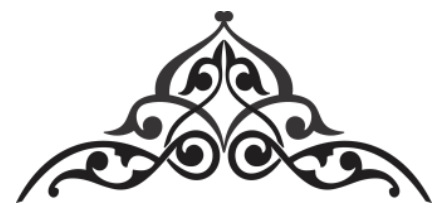

\title{
DINAMIKA PENDIDIKAN \& PENGAJARAN DI ERA PANDEMIC COVID-19
}

\section{Angga Putra, M.Pd ${ }^{1}$ STKIP YAPIS Dompu}

\begin{abstract}
"Di tengah pandemi, sistem pendidikan harus siap melakukan lompatan transformasi pembelajaran daring. Kita memasuki era baru untuk membangun kreatifitas, mengasah skills siswa, dan peningkatan kualitas diri dengan perubahan sistem, cara pandang dan pola interaksi kita dengan teknologi"
\end{abstract}

$\mathrm{D}$ unia sedang dilanda oleh bencana dan bencana ini bukanlah bencana biasa seperti tsunami, banjir, longsor maupun gempa bumi yang muncul setiap tahunnya, akan tetapi bencana kali ini adalah berupa sebuah virus mematikan yang disebut dengan COVID atau bahasa sederhananya yaitu CORONA. Covid 19 ini tidak hanya melanda Indonesia pada khususnya, akan tetapi telah melanda seluruh Negara yang ada di dunia dan telah menjadi bencana berskala internasional serta telah menimbulkan kepanikan yang luar biasa. Saking luar biasanya

1 Angga Putra lahir di Dompu, NTB, 12 November 1991, penulis merupakan Dosen Tetap di STKIP YAPIS DOMPU, dalam program studi Pendidikan Guru Sekolah Dasar (PGSD), penulis meraih gelar Sarjana Pendidikan (S.Pd) pada program studi PGSD di Universitas Muhammadiyah Makassar (Unismuh) pada Tahun 2014, sedangkan gelar Magister Pendidikan (M.Pd) di selesaikan di Universitas Negeri Makassar (UNM) pada program studi Administrasi Pendidikan (Kekhususan Pend.Guru Sekolah Dasar) pada tahun 2017. 


\section{1ै. Dinamika Pembelajaran \& Pengajaran di Era Pandemic...}

virus ini, telah memakan puluhan bahkan ratusan ribu korban jiwa pada setiap Negara, termasuk Indonesia.

Tingkat kekhawatiran ini tidak hanya persoalan banyaknya korban jiwa, akan tetapi berdampak besar juga pada persoalan, ekonomi, pendidikan, kesehatan, social dan politik bangsa, hal tersebut dikarenakan virus ini dapat menyebar lewat udara dan cepat tertular melalui sentuhan maupun dalam kondisi keramaian, sehingga pemerintah dalam setiap Negara khususnya Indonesia mewajibkan seluruh warganya untuk menjaga jarak bahkan yang lebih ekstrimnya lagi adalah berdiam diri di rumah, sedangkan manusia pada umumnya selalu keluar rumah atau beraktivitas diluar rumah, seperti bekerja, olahraga dan sebagainya.

Pemerintah sadar betul akan dampat dari pelarangan tersebut, akan tetapi hal tersebut merupakan bentuk antisipasi pemerintah dalam upaya meminimalisir tingkat penyebaran virus tersebut, dan jika memungkinkan ditambah dengan kesadaran masyarakat akan mampu untuk membasmi keberadaan virus itu. Dari sisi kesehatan dunia seperti WHO pun sampai sekarang lagi berupaya sedemikian rupa untuk menemukan obat untuk menyembuhkan orang-orang yang terkena penyakit tersebut, dan sampai sekarang belum di temukannya obat tersebut semakin membuat masyarakat menjadi semakin panik.

Dari beberapa dampak besar yang penulis sebutkan di atas seperti dampak ekonomi, pendidikan, keseharan, social dan politik. Penulis pada kesempatan ini memfokuskan pada dampak pendidikan di tengah penyebaran corona virus ini. Realitas terpampang jelas di hadapan kita bagaimana menurunya atau lumpuhnya system pendidikan kita ketika covid 19 masuk di Indonesia. Sistim pendidikan dalam hal ini pembelajaran dan pengajaran seakan lumpuh total, hal tersebut dibuktikan dengan

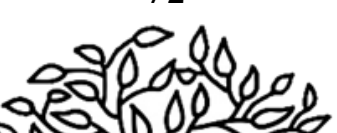


di liburkannya sekolah-sekolah, mulai dari jenjang TK, SD, SMP,SMA bahkan tingkat Perguruan Tinggi.

Pemerintah tidak kehilangan akal untuk melakukan langkah antisipasi terkait dengan lumpuhnya system pembelajaran dan pengajaran tersebut, hal itu dibuktikan dengan dianjurkannya seluruh daerah melalui keputusan resmi bahwa selama pandemic covid 19 berlangsung maka sistim pembelajaran dan pengajaran dilakukan secara daring (online), lebih kurang seperti itulah yang penulis pahami dari himbauan yang beredar tersebut. Akan tetapi tidak semua daerah siap dengan himbauan kuliah daring tersebut, lebih-lebih pada daerah-daerah terpencil yang masih jauh dari jangkauan teknologi, seperti telepon atau HP dan jaringan internet. Tetapi itulah langkah yang paling tepat yang dianggap mampu untuk menstabilkan kembali terkait dengan sistim dan pelayanan pendidikan dari dampak corona virus ini, apalagi Indonesia telah masuk dalam revolusi industry 4.0 , yang dimana segala sesuatunya sudah serba menggunakan teknologi, terlepas sumber daya manusia yang menggunakan teknologi yang semakin hari semakin meningkat, maka disinilah dilihat perkembangan manusia dalam memanfaatkan teknologi di era revolusi industry ini dengan sebaik-baiknya tidak terlepas oleh siapa saja akan tetapi berlaku untuk semua masyarakat.

Penulis sendiri baru pertama kali menggunakan kuliah daring (online), walaupun dulu semasa mengenyam pendidikan magister pendidikan pernah mempelajari e-learning akan tetapi dikarenakan pertemuan tatap muka di dalam kelas menurut saya tetaplah langkah yang paling efektif untuk melakukan transformasi pengetahuan kepada para mahasiswa, maka hal tersebut tidak saya gunakan bahkan bisa dibilang lupa, oleh karena himbauan yang mengharuskan melakukan sistim pembelajaran dan pengajaran jarak jauh dan perkuliahan diliburkan, maka untuk memastikan keberlangsungan pembelajaran mau tidak mau harus menggunakan sistim daring,

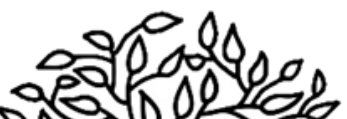




\section{| Dinamika Pembelajaran \& Pengajaran di Era Pandemic...}

pertamanya penulis sempat merasa kewalahan dalam hal memilih aplikasi apa yang akan digunakan dalam melakukan pengajaran tersebut. Memang di pemerintah telah menyarankan beberapa aplikasi seperti, Zoom Meating, Enmodo, Facebook bahwa Watsup dan lain sebagainya. Penulis sendiri dalam melaksanakan pembelajaran daring hanya melalui apliksi watsup group, selain dari aplikasinya ringan watsup juga bisa untuk mengirim file dan video. Akan tetapi persoalan yang kursial adalah sebagian mahasiswa masih ada yang belum memiliki leptop maupun HP yang berbasis android yang dapat digunakan untuk kuliah daring, kendala selanjutnya juga yaitu pada persoalan jaringan internet yang belum menyebar secara merata seperti di wilayah pedesaan dan tempat yang terpencil dan sebagian mahasiswa di tempat penulis mengajar adalah mayoritas dari golongan menegah ke bawah.

Semangat mahasiswa dalam melaksanakan pembelajaran meskipun secara daring atau online walaupun di tengah keterbatasan teknologi yang mereka miliki membuat penulis antusias untuk memberikan beberapa langkah kemudahan supaya para mahasiswa yang tidak memiliki teknologi yang berbasis android maupun yang terkendala jaringan tidak ketinggalan materi, salah satu kemudahan yang penulis berikan adalah dengan memberikan file materi perkuliahan yang nantinya akan dibagikan kepada para mahasiswa yang terkendala tersebut untuk dibaca dan dipelajari, ada file yang berbentuk cetak yang telah penulis rancang sedemikian rupa segingga tidak keliahatan terlalu banyak dan ada yang di bagikan dalam bentuk file word atau pdf agar sebagian mahasiswa yang memiliki leptop maupun HP bisa mempelajarinya kapan saja dan dimana saja, setelah itu diberi beberapa kali evaluasi untuk melihat sejauh mana pemahaman para mahasiswa/mahasiswa terkait dengan materi yang diberikan.

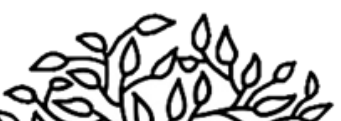


Revolusi industry 4.0 yang mengharuskan tenaga pengajar dalam hal ini guru maupun dosen untuk beradaptasi dengan teknologi, karena di era ini teknologi merupakan sebagai system penunjang dalam upaya meningkatkan kreatifitas guru maupun dosen dalam mentrasformasikan pembelajaran berbasis teknologi, sesuai dengan perkembangan jaman yang semakin maju maka teknologi sebagai jembatan bagi guru maupun dosen untuk bertransformasi dari sistim pembelajaran yang manual ke dalam sistim pembelajaran yang berbasis teknologi. Maka guru dan dosen harus menyesuaikan dan meningkatkan kemampuannya dalam menguasai dan memahami teknologi, sehingga dalam pembelajaran dan pengajaran yang dilakukan harus memanfaatkan teknologi seperti membuat bahan ajar, power point pembelajaran, media pembelajaran dan sebagainya, hal itu dilakukan agar pemahaman mahasiswa maupun siswa dapat lebih maksimal lagi sehingga pola pikirnya bisa mengikuti perkembangan jaman yang semakin lama semakin maju dan berkembang.

Di sebagian daerah, termasuk daerah tempat penulis mengabdikan diri masih banyak kendala untuk memaksimalkan kuliah daring ini, persoalan ini memang dianggap wajar oleh dosen maupun mahasiswa karena kurangnya pelatihan dalam mengkreasikan kegiatan pembelajaran dengan memanfaatkan teknologi dan dari sisi mahasiswanya juga belum terbiasa dalam hal pembelajaran jarak jauh ini, sehingga membutuhkan waktu untuk beradaptasi, berbeda dengan mahasiswa yang ada di ibukota yang fasilitas yang dimilikinya sudah lengkap dan memadai serta mahir dalam menggunakan teknologi.

Lewat kesempatan ini, penulis mengajak semua pihak agar melakukan kreatifitas dalam mendesai pembelajaran yang dianggap efektif sehingga tidak ketinggalan dan terbelakang dalam mengikuti arus teknologi, walaupun di beberapa daerah pembelajaran daring (online) ini masih kurang maksimal akat

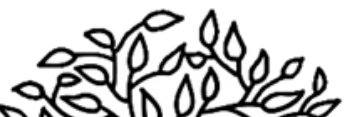




\section{1ै. Dinamika Pembelajaran \& Pengajaran di Era Pandemic...}

tetapi harus diupayakan mengikuti perkembangan jaman, bisa melalui pemerintah daerah maupun pihak terkait mengenai pengadaan jaringan teknologi yang merata sehingga akses dunia bisa dirasakan oleh masyarakat pelosok atau terpencil, demi terciptanya sumber daya manusia yang bisa bersaing dalam arus teknologi yang berkembang saat ini.

Melalui bencana covid 19 ini banyak mengajarkan kita dalam mempersiapkan diri untuk mengambil langkah stategis dalam mengasah kemampuan dan kreatifitas untuk menggunakan teknologi sebagai antisipasi kegiatan jarak jauh, sehingga kelak tidak kaget dengan kondisi yang mengharuskan kita untuk melakukan pembelajaran dari rumah sekaligus betulbetul dapat terjun langsung dalam era revolusi industry sebagai era teknologi.

Semoga pandemic covid 19 ini cepat berakhir sehingga ketidakstabilan dalam sistim pendidikan lebih khusus dalam hal pembelajaran dan pengajaran bisa optimal kembali, karena walau bagaimanapun sisitim pembelajaran tatap muka masih merupakan langkah optimal untuk saat ini, terlepas dari itu semua kualitas guru dalam hal teknologi tetap harus ditingkatkan lagi, sebisa mungkin sering mengikuti pelatihanpelatihan yang berkaitan dengan pembelajaran online untuk menambah pengalaman. Kita sebagai tenaga pengajar sudah menjadi suatu keharusan untuk selalu memberika yang terbaik bagi pendidikan, apapun alasanya pendidikan harus tetap terus berjalan demi menciptakan generasi bangsa yang berkualitas, oleh karena demikian kerjasama dari seluruh pihak terutama pihak-pihak yang berkaitan erat dengan dunia pendidikan agar dapat memaksimalkan pelayanannya sehingga proses pembelajaran dapat berjalan sebagaimana mestinya dan tujuan pendidikan maupun pembelajaran tercapai.

Pendidikan merupakan garda terdepat dalam memajukan suatu bangsa, jika garda ini dalam implemntasinya kurang

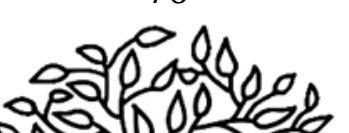


optimal dikarenakan covid 19, maka bisa dibayangkan rendahnya mutu maupun kualitas pendidikan di Indonesia, lebih-lebih akan berdampak besar pada menurunnya kualitas guru maupun dosen dalam membentuk bibit unggul demi memajukan bangsa dalam era modernisasi yang semakin hari semakin berkembang pesat.

Demikian, semoga dapat menjadi cambukan untuk segenap pihak dalam lingkup pendidikan dalam memaksimalkan mutu dan kualitas pendidikan meskipun dalam keadaan covid 19 yang meraja lela hamper di seruh bagian Negara. 
| Dinamika Pembelajaran \& Pengajaran di Era Pandemic... 


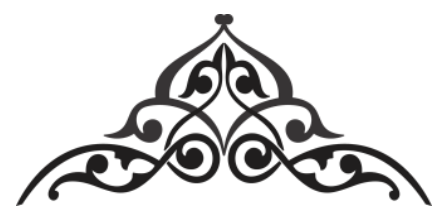

\title{
STRATEGI PEMBELAJARAN ONLINE DI MASA PANDEMIC
}

\author{
Nurhayati, M.Pd ${ }^{1}$ \\ STIES Baktiya Aceh Utara
}

"Dalam kondisi pandemi ini, menuntut lembaga semua pendidikan untuk melakukan inovasi dalam proses pembelajaran, salah satu bentuk inovasi ialah dengan melakukan pembelajaran secara online atau daring"

$\mathrm{U}$ ntuk mewujudkan tujuan pembelajaran atau kompetensi yang diharapkan, salah satu elemen yang sangat menentukan adalah pendidikan oleh karena itu, pendidikan dituntuk untuk membuat desain pembelajaran yang tepat untuk diterapkan disekolah. Pembelajaran pada hakikatnya merupakan upaya pendidik dan perancangan pembelajaran merupakan penataan upaya agar muncul perilaku belajar. Dalam kondisi yang tertata supaya tujuan dan misi pembelajaran itu jelas, strategi atau cara pembelajaran yang optimal, sagat bagus dan berpeluang untuk memudahkan proses belajar dan mengajar.

Dalam metode pembelajaran sudah mencakup semua cara yang dapat dipakai untuk mencapai tujuan dan proses pembelajaran dalam keadaan/kondisi yang tertentu. Metode

1 Nurhayati lahir di Aceh pada tanggal 2 juli 1990, Dosen di STIES Baktiya Aceh Utara, Menyelesaikan pendidikan sarjana pada tahun 2012 di Universitas Islam Temiang dan mendapatkan gelar magister manajemen pada tahun 2019 di IAIN Lhok seumawe, Penulis mempunyai pengalaman mengajar di SMPN kurang lebih 2 tahun dan di pespustakaan STIES Baktiya. 
adalah strategi mengorganisasi isi pembelajaran, strategi menyampaikan isi pembelajran dan strategi mengolola pembelajaran. Dalam kondisi saat ini lembaga pendidikan di tuntut untuk melakukan inovasi dalam proses pembelajaran, salah satu bentuk inovasi ialah dengan melakukan pembelajaran secara online atau daring. Akan tetapi dalam pembelajaran daring ini tidak terlepas dari pemasalahan dan hambatan dalam pelaksanaannya .

Dalam perkembangan zaman yang semakin maju dan dalam kemajuan teknologi dan informasi saat ini dapat dimanfaatkan sebagai pendukung dalam proses belajar mengajar di dunia pendidikan, pengunaan teknologi dalam proses pembelajaran dalam jaringan di lembaga pendidikan sudah banyak diterapkan dan telah menunjukan efektifitasnya dalam mendukung penyelenggaraan pendidikan. Dalam pengunaan teknologi digital banyak ragam yang dapat dijadikan peluang bagi peningkatan mutu pendidikan yang berkualitas dalam proses belajar mengajar di era pandemic saat ini. Ada banyak penelitian yang sudah dilakukan sebelumnya dan hasilnya menunjukan ada pro dan kontra tentang pemanfaatan teknoligi digital dalam meningkatkan peningkatan belajar mengajar.

Terkain dampak covid 19 pada saat ini, dengan adanya system digital menuntut para pendidik dan peserta didik untuk mampu dengan cepat beradaptasi dengan perubahan yang ada. Sistem pembelajaran yang semula berbasis tatap muka secara langsung, bukan tidak mungkin akan dapat diganti dengan system pembelajaran berbasis internet (siste pembelajaran online).

Perubahan pola pembelajaran saat ini masih dilakukan mulai dari tingkat sekolah dasar, menegah bahkan sampai ke perguruan tinggi. Sangat banyak sekali bahkan lebih dari 1,5 miliar pelajar didunia tidak bisa belajar tatap muka secara langsung disekolah akiban virus corona saat ini. Masalah ini

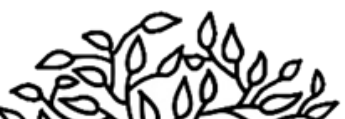


tentunya menuntut instansi pendidikan dan pendidik (guru dan dosen) yang menjadi garda terdepan untuk menerapkan proses pembelajaran yang tepat. Agar covid 19 tidak cepat menyebar pemerintah menerapkan belajar dirumah, bekerja dirumah dan menerapkan jaga jarak dan diharus untuk belajar secara online.

Dalam system pembelajar online ada sebagian berpendapat bahwa system ini dapat mempermudah proses belajar mengajar dalam masa pandemic saat ini, dengan adanya system ini dapat menjadi solusi dalam kondisi pandemic, dan sebagian lagi mengatakan bahwa system pembelajaran online ini tidak dapat mempermudah pembelajaran, dalam hal ini kemungkinan karena sebagian tidak terbiasa dengan pembelajaran secara online biasa dengan pembelajaran tatap muka, oleh karena itu meraka harus menyesuaikan diri dengan pembelajaran online. ${ }^{1}$

\section{A. Pembelajaran online}

Pembelajaran online adalah system belajar mengajar yang mengunakan teknologi internet, menurut Dabbagh dan Ritland 2005:15 ada beberapa macam model pembejaran online, strategi intruksional dan pembelajaran, dan media pembejaran online. Pembelajaran online adalah pembelajaran yang memanfaatkan keungulan computer sebagai media perantara pengajar dan pelajar agar mudah berkomunikasi. Pembelajaran online memberikan kesempatan kepada pelajar untuk mengajukan pertanyaan atau mengemukakan pendapat secara tidak langsung. Pembelajaran online memanfaatkan bahan ajar yang bersifat mandiri yang dapat diakses siapa saja dan kapan saja melalui teknologi internet. Pembelajaran online akan memudahkan penyempurnaan dan penyimpanan materi-materi

1 Penulis lahir di Aceh pada tanggal 2 juli 1990, Dosen di STIES Baktiya Aceh Utara, Menyelesaikan pendidikan sarjana pada tahun 2012 di Universitas Islam Temiang dan mendapatkan gelar magister manajemen pada tahun 2019 di IAIN Lhok seumawe, Penulis mempunyai pengalaman mengajar di SMPN kurang lebih 2 tahun dan di pespustakaan STIES Baktiya.

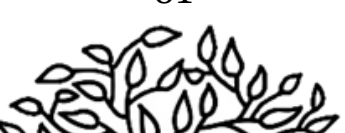


sehingga mudah untuk diakses kapan saja dan dimana saja ketika dibutuhkan.

\section{B. Kelebihan dan hambatan Pembalajaran Online (E- Learning)}

Media pembelajaran online dapat diartikan media yang dilengkapi dengan alat pengontrol yang dapat dioperasikan oleh pengguna sehingga pengguna dapat mengendalikan dan mengaksek apa yang jadi kebutuhan pengguna. Keuntungan media pembelajaran online adalah pelajaran bersifat mandiri dan interaktivitas yang tinggi, mampu meningkatkan tingkat ingatan memberikan lebih banyak pengalaman belajar.

Pembelajaran online memberikan pengaruh yang lebih tinggi dari pada pembelajaran offline yaitu tatap muka terhadap prestasi belajar. Dari hasil penelitian Mulyani (2013) juga mengatakan hal yang sama, dalam proses pembelajaran, pembelajar tatap muka jika di bandingkan dengan pembelajaran online, maka pembelajaran online sangat berpengaruh terhadap siswa.

Akhir-akhir ini dengan tersebarnya wabah virus corona didalam dunia pendidikan diterapkan pembelajaran online, maka dari itu banyak aplikasi yang dapat digunakan, seperti aplikasi google meet, google classroom, zoom, whatsapp, wattpad, dan lainnya. Dalam hasil karya Kurniawan Arizona et.al 2020 menyatakan bahwa dengan mengunakan aplikasi google classroom, dengan aplikasi tersebut para pelajar dan pengajar dapat melakukan atau melaksanakan tugas-tugasnya dengan baik sebagai pelajar dan pengajar. Pembelajaran online yang diterapkan memungkinkan pengajar dan peserta didik dapat melangsungkan pembelajaran tanpa melalui tatap muka di kelas dengan pemberian materi-materi pembelajaran baik dengan video atau materi lainya

Dalam pengunaan aplikasi tersebut pengajar dan peserta didik dimungkinkan untuk berinteraksi melalui diskusi terkait

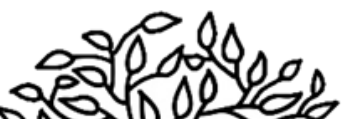


dengan permasalahan materi dan jalannya pembelajaran secara efektif. Sabara 2018 menyatakan hal yang sama dengan pengunaan aplikasi google classroom secara keseluruhan cukup efektif.

Dalam karya Sari 2019 mendapatkan hasil yang serupa, dalam penggunaan aplikasi tersebut mempunyai kelebihan manfaat dan kualitas terhadap pembelajaran secara online. Selain aplikasi google classroom ada aplikasi yang serupa yaitu Edmodo, setiap aplikasi mempunyai kelebihan masing-masing, aplikasi ini bisa di pantau oleh orang tua, sehingga cocok untuk anak sekolah dasar.

Selain dua aplikasi tersebut, aplikasi whatsapp juga lebih banyak memanfaatkan aplikasi whatsapp, teknik whatsapp diakui dapat melakukan pembelaran secara evektif, dengan mengunakan whatsapp para pelajar dapat pengetahuan seperti seminar online tanpa harus tatap muka dan berdiskusi, berinteraksi dengan mudah tanpa harus tatap muka. Selain beberapa aplikasi yang sudah disebutka diatas masih banyak lagi aplikasi lainnya yang digunakan ditengah-tengah situasi pandemic. Adit, 2020.

Sayangnya ada beberapa permasalahan yang dihadapi saat melakukan pembelajaran online terutama akses internet (paket data) dan belum terbiasanya pengajar dan peserta didik menggunakan aplikasi pembelajaran online. Kendala yang paling sering muncul selama pelaksanaan pembelajaran online yaitu paket internet yang tidak dimiliki peserta didik, keterbatasan akses internet, jaringan tidak stabil juga merupakan hambatan dalam proses pembelajaran, keberadaan fasilitas jaringan merupakan hal yang utama dalam pembelajaran online karena berkaitan dengan kelancaran proses pembelajaran, keberadaan pelajar dan pengajar yang jauh dari pusat kota ataupun jauh dari jangkoan jaringan provider tentunya tidak dapat melaksakan proses pembelajaran dengan lancar, Sementara hambatan

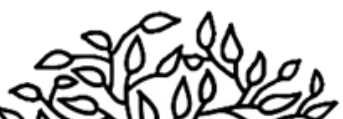




\section{| Strategi Pembelajaran Online di Masa Pandemic}

terbesar yang dirasakan pelajar adalah adanya tugas yang menumpuk, kondisi pembelajaran dengan system daring yang masih belum bisa menyesuikan dengan baik.

Ada beberapa yang memanfaatkan aplikasi pembelajaran online baik secara mandiri maupun kelompok, sebagian mengunakan pembelajaran online melalui video dengan mengunakan aplikasi zoom meeting, dalam penyampain materi paling banyak dilakukan dengan membagi file melalui pesan whatsapp. Dan ada juga yang mengunakan aplikasi wattpad, dengan aplikasi wattpad pelajar dapat membaca materi-materiterkait

\section{DAFTAR PUSTAKA}

Adit, A. 2020. 12 Aplikasi pembelajaran daring kerjasama kemendikbud gratis https://edukasi.kompas .com/read/2020/03

Dabbgh. Dan Kitland. BB 2020. Online learing. Concepts. Strategi and Application. Ohio: person

Gunawan. Surati, Nmy dan Fathoroni 2020. Variations of models and learning platforus for pros pective teachers during the covid 19 pandemic period Indonesia jurnal of teacher education. 12 . 61-70

Kurniawan Arizona, et.al 2020 Jurnal ilmiah profesi pendidikan: 5(1):64 - 70 DOI: 1029303 jpp.1.111

Sabran \& Sabara, E. (2018). Keefektifan Google Classroom sebagai media pembelajaran. https://ojs.unm.ac.id/semnaslemlit/artikel/veiw/8256

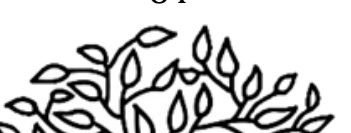




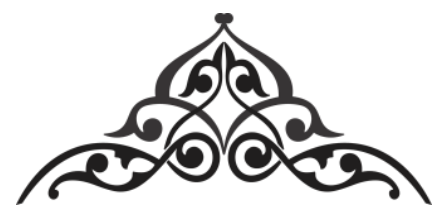

\title{
LANGKAH STRATEGIS UNTUK MENUNJANG PEMBELAJARAN DARING AKIBAT PANDEMI COVID-19
}

\author{
Nur Wahyuni, M.Pd. ${ }^{1}$ \\ STKIP Yapis Dompu
}

\begin{abstract}
"Langkah strategis diperlukan agar bisa bertahan dalam masa pandemi ini, di antaranya mengubah pola pikir tentang metode belajar, menyiapkan metode baru untuk pengembangan sumber belajar Daring serta mencetak tenaga pendidik yang adaptif dalam teknologi pembelajaran"
\end{abstract}

Dada awal tahun 2020, dunia di kejutkan dengan kemunculan
sebuah virus yang disebut dengan corona virus atau degan kata lain (COVID-19). Virus jenis ini dapat menular sangat cepat, jadi karena penularan COVID-19 sangatlah cepat sehingga sebuah Organisasi Kesehatan Dunia atau (WHO) menetapkan bahwa virus corona atau COVID-19 ini sebagai pandemi pada tanggal 11 Maret 2020. Pada saat sebuah organisasi WHO mengeluarkan status epidemi global ini menandakan bahwa penyebaran COVID-19 berlangsung sangatlah cepat sehingga

1 Nur Wahyuni lahir di Bima, Nusa Tenggara Barat, 11 Nopember 1990, penulis merupakan Dosen di STKIP Yapis Dompu dalam bidang ilmu Pendidikan Bahasa Inggris, penulis menyelesaikan gelar Sarjana Pendidikan Bahasa Inggris di Institut Keguruan dan Ilmu Pendidikan Mataram (2013), dan gelar Magister Pendidikan di selesaikan di Universitas Muhammadiyah Surakarta Program Studi Magister Pengkajian Bahasa (2017). 


\section{" Langkah Strategi untuk Menunjang Pembelajaran Daring...}

hampir seluruh negara di dunia tidak dapat terhindar dari virus corona atau COVID-19 in. Pada awal kemunculan corona virus ini hanya terdapat di Negara China provinsi Wuhan tetapi kini virus corona atau COVID-19 kini telah menjadi pademi di seluruh dunia, sehingga pemerintah di berbagai negara telah menerapkan sistem lockdown atau karantina untuk mencegah penularan covid-19 semakin meluas lagi di masing-masing negara tersebut. Pemerintah Indonesia sendiri telah menghimbau kepada seluruh warga nya untuk tetap di dalam rumah dan mengisolasi diri atau melakukan karantina mandiri. Salah satunya Pemerintah Indonesia telah mengeluarkan peraturan baru yaitu untuk semua masyarakat nya agar bisa melakukan atau mentaati peraturan yang sudah di keluarkan oleh pemerintah yaitu melaksanakan menerapkan aturan PSBB yang merupakan singkatan dari Pembatasan Sosial Berskala Besar yang dibuat dalam rangka Penanganan COVID-19. Hal ini dilakukan dengan harapan agar virus corona ini tidak menyebar dengan cepat dan secara lebih luas lagi, sehingga upaya pemerintah untuk mencegah virus corona ini makin meluas bisa terealisasi dengan tepat dan supaya juga harapan terbesar dari pemerintah adalah agar penyembuhan dapat berjalan lebih cepat dan lebih maksimal lagi untuk para pasien yang sudah dinyatakan positif virus corona.

Dalam usaha pembatasan sosial distencing ini pemerintah Indonesia juga telah membatasi kegiatan diluar rumah seperti salah satunya adalah pada kegiatan pendidikan yang kini telah berubah dari sistem offline menjadi ke sistem online biasa di sebut dengan sistem daring. Kebijakan ini di ambil oleh pemerintah indonesia sudah melalui pertimbangan yang luar biasa menggingat setiap hari nya jumlah pasien positif virus corona semakin bertambah, sehingga Mentri pendidikan memutuskan untuk merubah sistem pembelajara ini menjadi sistem online atau dengan kata lain pemerintah menganjurkan

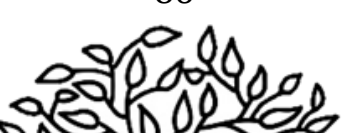


supaya kita dapat menerapkan pembelajaran secara daring, langkah ini di ambil karna untuk mencegah penyebaran covid-19 semakin meluas, mengingat peningkatan jumlah kasus positif di Indonesia akibat COVID-19 semakin meningkat sehingga membuat Kementerian Pendidikan dan Kebudayaan (Kemendikbud) mengambil keputusan membuat kebijakan untuk merekomendasikan pembelajaran daring sebagai upaya menurunkan angka penyebaran virus corona.

Pada awalnya hampir semua mahasiswa ataupun pelajar dari sejumlah perguruan tinggi dan sekolah-sekolah di Indonesia merasa kebingungan dengan sistem yang baru ini. Terutama yang berada di pelosok negeri ini, di tengah segala keterbatasan akibat pandemi covid-19 ini para mahasiswa dan pelajar harus berjibaku dan berjuang di tengah keterbatasan yang dimiliki supaya untuk memahami lebih cepat cara belajar dengan sistem online yang dikerjakan melalui beberapa aplikasi yang di gunakan oleh para Dosen pengampu mata kuliahnya ataupun para guru masing-masing, mereka harus bekerja lebih keras di bandingkan dengan mahasiswa ataupun pelajar yang berada di kota besar karena mereka banyak yang tidak mahir bahkan tidak bisa untuk menaplikasikan media pembeajaran secara online karena hal ini merupakan hal baru untuk para mahasiswa ataupun pelajar dikarenakan minimnya pengetahuan para mahasiswa atau pelajar itu sendiri dalam memanfaatkan kemajuan teknologi sekarang. Hal ini dikarenakan ketidak mampuan mereka untuk memiliki alat komunikasi yang cangih di karenakan oleh faktor ekonomi yang berada di bawah garis kemiskinan untuk sebagian dari para pejuang ilmu ini.

Walaupun demikian ada beberapa universitas ternama di Indonesia yang sudah siap untuk melakukan perkuliahan online karena memiliki fasilitas yang lebih menunjang dari berbagai aspek seperti jaringan untuk melaksanakan pembelajaran secara online lebih baik dan bagus, tetapi hadirnya

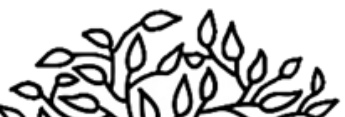




\section{Langkah Strategi untuk Menunjang Pembelajaran Daring...}

COVID-19 menunjukkan ketidaksiapan jauh lebih banyak institusi pendidikan di Indonesia dalam menerapkan sistem pembelajaran daring terlebih untuk yang berada di pelosokpelosok Negeri, hal ini dikarenakan untuk mengakses internet masih terasa sulit karena jaringan yang di butuhkan untuk beberapa aplikasi tidak mampu terkoneksi dengan baik. Jadi untuk pemanfaatan teknologi pembelajaran daring masih didominasi oleh universitas di kota besar karena kapasitas finansial dan ketersediaan sistem pembelajaran digital yang lebih baik dibandingkan kampus kecil di daerah-daerah pelosok. Namun tidak sedikit pula dari jumlah para pendidik yang masih merasakan kesulitan dalam menggunakan teknologi pembelajaran daring terlebih untuk dosen-dosen yang sudah berumur karena hal ini merupakan hal baru lagi untuk mereka pelajari kembali, sehingga tidak jarang para Dosen yang masih kurang paham dalam mengaplikasikan kuliah onlie ini hanya berakhir dengan memberikan tugas secara jarak jauh tanpa ada umpan balik maupun interaksi dengan para mahasiswa.

Jadi disini saya menuliskan beberapa saran untuk memulai langkah strategis untuk mendukung pembelajaran daring akibat dampa dari Covid-19, semoga ini menjadi lebih efisien dan mudah untuk semua pihak supaya tidak ada salah satu pihak yang merasa berat menjalankan atau melaksanakan apa yang sudah di tetapkan oleh Kemendikbud untuk mengatasi permasalahan ini dan mendukung pembelajaran daring di Indonesia, bahkan pasca pandemi COVID-19 ini usai.

\section{Mengubah Pola Pikir Dari Pendidik Maupun Mahasiswa Tentang Metode Belajar Dengan Sistem Yang Baru}

Dengan semakin pesatnya perkembangan teknologi dan internet di jaman sekarang, mungkin saja 25-30 tahun nanti akan terjadi banyak sekali perubahan yang terjadi di dunia pendidikan terutama dalam proses pembelajaran karena 
bisa jadi nanti nya proses pembelajaran dapat terjadi kapan saja dan dimana saja dengan memanfaatkan kecangihan teknologi informatika, dan dengan siapa saja tanpa ada batas ruang dan waktu. Sungguh di sayangkan karena pola pendidikan di Indonesia saat ini masih terlihat belum adaptif terhadap perkembangan yang terjadi saat ini. Rata-rata para orang tua, masih menjunjung tinggi kepercaya bahwa pendidikan formal yag dilakukan di dalam kelas merupakan satu-satunya jaminan untuk memperoleh pekerjaan sehingga akan sedikit kesulitan untuk kita melakukan terobosan baru seperti ini, tetapi juga tidak menutup kemungkinan bahwa belajar melalui daring akan di terima nantinya karena kembali lagi semua tergantung pada waktu yang tepat.

Sebagai langkah awal dalam perencanaan ini di harapkan kepada Kemendikbud agar supaya mengkomunikasikan hal ini terlebih dahulu kepada masyarakat supaya untuk menyadarkan masyarakat terlebih lagi untuk menyadarkan para orang tua bahwa nantinya kita tidak hanya membutuhkan satu skill dalam dunia kerja tetapi juga kita harus mempunyai banyak skill atau keterampilan lainnya yang lebih kreatif dan inovatif lagi, sehingga hal-hal seperti ini tidak cukup hanya diajarkan melalui kelas formal saja. Beberapa peneliti sudah banyak meneliti tentang penelitian hal ini dan sudah banyak yang menjelaskan model belajar di dalam ruang kelas itu hanya efektif untuk mengembangkan kemampuan dasar dan menjelaskan berbagai materi baru, hal ini dirasa masih kurang efektif untuk menggasah motorik anak agar lebih aktif dalam menyelesaikan berbagai masalah yang ada secara kreatif dan inovatif.

Salah satu cara agar Kemendikbud bisa menerapkan metode pembelajaran baru tersebut adalah dengan merumuskan kembali kurikulum yang lebih sesuai

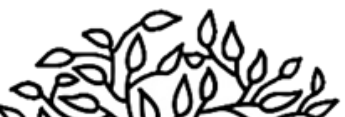


dengan tuntutan keterampilan di jaman millenial ini sehingga bisa menciptakan lulusan-lulusan yang terbaik di bidangnya masing-masing. Misalnya, kurikulum saat ini bisa menggunamakan lebih banyak lagi pembelajaranpembelajaran campuran antara tatap muka dan digital (blended learning) hal seperti ini dirasa cukup efektif untuk membuat terobosan baru di dalam wajah pendidikan kita saat ini.

\section{Menyiapkan Konsep Baru Untuk Pengembangan Sumber Belajar Dengan Daring}

Pemanfaatan berbagai fitur yang tersedia untuk membuat kelas daring melalui berbagai sistem secara aktif dan terbuka menjadi salah satu tren praktik pembelajaran daring yang paling efektif saat ini, sehinga mungkin saja bisa menggunakan platform yang menyediakan kelas daring melalui sistem Massively Open Online Courses (MOOC) secara masif dan terbuka. Beberapa contoh MO0C yang ternama secara internasional adalah Coursera, EdX, dan Khan Academy. Meski pun MOOC di Indonesia sudah mulai dikembangkan, namun terdapat beberapa permasalahan. Salah satu masalah yang dihadapi adalah jumlah kelasnya yang masih sangat sedikit, msalah lain juga muncu terkait dengan studi tentang MOOC di Indonesia juga menunjukkan tingkat penyelesaian pada kelas daring yang sudah tersedia pun masih minim hal ini di akibatkan karena materi yang dirasa masih kurang lengkap dan tidak menarik untuk para mahasiswa ataupun siswa. Selain itu, ruang lingkup juga mempengaruhi setiap penggunanya karena hanya terbatas untuk wilayah disekitar kampus saja. Regulasi yang sudah ada tentang pendidikan jarak jauh belum mengatur tentang pengembangan sumber materi seperti platform MOOC maupun standar yang harus dipenuhinya. Dengan landasan hukum, standar kualitas, dan sistem akreditasi yang jelas,

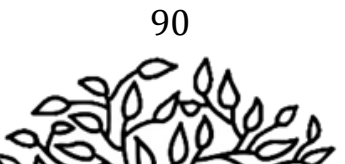


Kemendikbud dapat mengembangkan sendiri maupun berkolaborasi dengan universitas lain untuk untuk memperkaya koleksi kuliah daring pada platform MOOC mereka.

Jadi menurut saya, struktur seperti ini seharusnya bisa membuka ruang bagi seluruh mahasiswa di seluruh universitas kecil untuk mengambil kelas di universitas yang lebih besar, syaratnya cukup dengan daring melalui platform MOOC yang dimiliki oleh mereka masing-masing. Namun, hal ini harus ditunjang juga oleh regulasi yang mengatur tentang sistem kredit semester (SKS) dan sertifikasi kelas pada pembelajaran yang berbasis MOOC ini.

\section{Mencetak Tenaga Pendidik Yang Adaptif Dalam Teknologi Pembelajaran}

Menurut beberapa penelitian bahwa kemampuan pendidik dalam membuat strategi belajar menjadi factor terpenting karena ini merupakan salah satu poin penentu keberhasilan pada pelaksanaan pembelajaran melalui sistem daring. Di antaranya, para pendidik merancang, mengorganisir, serta mengendalikan aktivitas dan materi belajar yang interaktif untuk mencapai tujuan belajar yang maksimal dan mendapatkan hasil yang terbaik.

Pada kondisi saat ini, banyak pendidik hanya memberi tugas melalui aplikasi tanpa adanya umpan balik dari para pelajar, lalu mereka bisa menganggap pekerjaannya sebagai pendidik sudah selesai tanpa ada perencanaan strategi belajar jangka panjang untuk kedepannya, para pendidik hanya sekedar memindahkan pembelajaran yang dari sistem offline ke sistem online sehingga terjadi pembelajaran satu arah dari yang biasanya di kelas. Hal ini justru membuat kesan tidak menyenangkan untuk para mahasiswa dalam melakukan pembelajaran daring. Di sini, penguasaan tenaga pendidik terhadap teknologi pembelajaran,

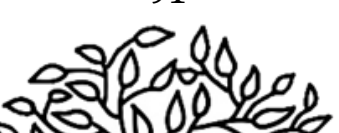


atau technological pedagogical knowledge sangatlah di butuhkan untuk membuat strategi belajar dan fasilitas yang dimiliki para pelajar, menjadi kompetensi yang sama pentingnya.

Hal utama yang harus dilakukan oleh Kemendikbud adalah focus pada pelatihan mengenai pengintegrasian teknologi dalam menunjang kegiatan belajar mengajar agar lebih menarik, terutama untuk para calon guru harus mengikuti setiap aspek yang sudah di anjurkan, mulai dari Lembaga Pendidikan Tenaga Kependidikan (LPTK) sampai program pelatihan Kemendikbud yang lainnya. Untuk mengurangi kesenjangan akses pada fasilitas jaringan internet, pemerintah juga perlu berkolaborasi dengan berbagai industri di bidang telekomunikasi yang ada di indonesia. Misalnya, melakukan kolaborasi perguruan tinggi dengan operator telekomunikasi untuk melaksanakan pembelajaran jarak jauh yang mungkin saja bisa difasilitasi oleh Dewan Teknologi Informasi Nasional. 


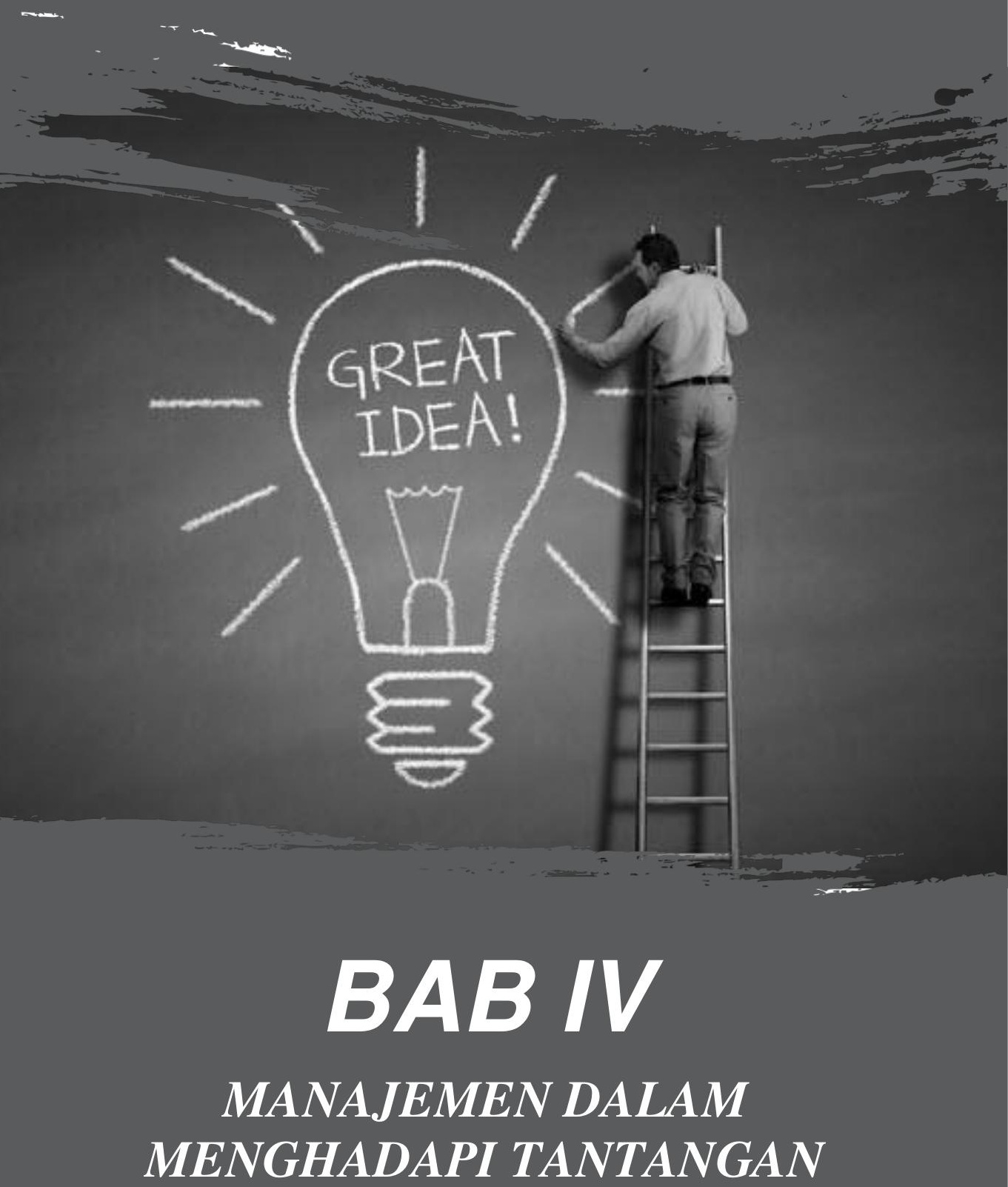




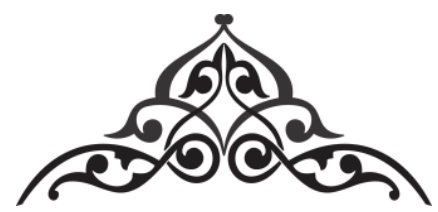

\title{
PANCA RE-SI MANAJEMEN PERUBAHAN STRATEGI BARU DI ERA NORMAL BARU
}

\author{
Aang Kunaifi, SE., M.EI ${ }^{1}$ \\ Institut Agama Islam Al-Khairat Pamekasan
}

"Dasar manajemen perubahan dalam masa normal

baru dibutuhkan kemauan untuk melakukan

perubahan dan semangat belajar supaya strategi baru

organisasi berjalan secara efektif"

Deradaban manusia selalu berubah, bahkan tidak ada sesuatu
dimuka bumi ini yang tidak mengalami perubahan. Satusatunya yang tetap adalah perubahan itu sendiri. Siapapun yang memahami dinamika peradaban, pasti tidak akan mudah panic saat menyaksikan atau mengalami suatu perubahan. Kemampuan manusia dalam berpikir dan melakukan analisis merupakan bekal dan potensi untuk menghadapi setiap keadaan, itulah yang seringkali disebut sebagai daya intelektual. Kemampuan intelektual merupakan keutamaan yang diberikan oleh Allah swt kepada manusia. Intelektualitas diberikan agar manusia memikirkan keadaan di sekitarnya lalu mencari solusinya. Sebagaimana disebutkan dalam Al-Qur'an yang

1 Aang Kunaifi adalah dosen tetap sekaligus Ketua Program Studi Ekonomi Syariah pada Fakultas Ekonomi dan Bisnis Islam IAI Al-Khairat Pamekasan. Selain mengajar juga mengelola bisnis retail AMC Bookstore di Pamekasan dan aktif sebagai sekretaris Ikatan Ahli Ekonomi Islam (IAEI) Komisariat IAI Al-Khairat Pamekasan. Untuk komunikasi lebih lanjut bisa melalui email: akunaifi@gmail.com 


\section{"}

artinya: Mereka mempunyai hati, namun tidak digunakan untuk berfikir (TQS. Al-A'raf:179).

Mengantisipasi dan menghadapi perubahan merupakan keniscayaan bagi manusia. Inilah sebenarnya makna dari penciptaan manusia sebagai khalifah fil ard, yaitu untuk mengkondusifkan setiap keadaan. Manusia diciptakan untuk menyelesaikan masalah sekaligus menata kehidupan di dunia berdasarkan tuntunan-Nya. Dengan kata lain, manusia adalah subyek dalam seluruh dinamika kehidupan dan peradaban.

\section{Manajemen Perubahan}

Manajemen diartikan sebagai penggunaan sumber daya secara efektif untuk mencapai sasaran; atau pimpinan yang bertanggung jawab atas jalannya perusahaan dan organisasi (kbbi.web.id). Perusahaan dalam etimologi manajemen di atas menunjukkan bahwa istilah manajemen cenderung digunakan dalam bidang ekonomi. Namun kenyataannya manajemen merupakan istilah yang dapat digunakan pada bidang lain.

Secara aktual, manajemen dapat diartikan sebagai konsep dan metode dalam mencapai tujuan organisasi melalui proses perencanaan, aksi, evaluasi, dan perbaikan. Oleh karena itu, perubahan menjadi keniscayaan bagi suatu individu maupun organisasi. Stimulus perubahan bisa berasal dari kondisi internal, yaitu perubahan akibat hasil evaluasi dan perbaikan. Perubahan juga bisa distimulus dari kondisi eksternal seperti budaya, regulasi, teknologi, dan lain sebagainya. Dengan demikian, perubahan membutuhkan konsep, ide, cara, teknik, dan metode baru yang bisa kita kemas dalam istilah manajemen perubahan.

Manajemen perubahan adalah konsep dan metode untuk memecahkan masalah dalam lingkungan social, serta mengelola solusi yang dihasilkan. Manajemen perubahan bisa dimiliki

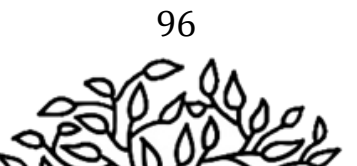


individu, organisasi, dan pemerintah sebagai subyek dalam penciptaan peradaban manusia. Allah swt berfirman yang artinya; Sesungguhnya Allah tidak mengubah keadaan sesuatu kaum sehingga mereka mengubah keadaan yang ada pada diri mereka sendiri (TQS. Al-Ra'du:11). Maka menghadapi perubahan adalah bentuk tanggungjawab untuk menjaga peradaban yang ideal.

\section{Strategi Organisasi}

Strategi dapat diartikan sebagai langkah-langkah penting atau kebijakan-kebijakan pokok yang menjadi haluan organisasi. Strategi yang baik menciptakan daya saing dan keberlangsungan organisasi. Organisasi dunia bisnis, pendidikan, social, masyarakat, politik juga pemerintahan (Kunaifi, 2016:145). Berkaitan dengan pentingnya strategi, Allah swt berfirman: Dan siapkanlah untuk menghadapi mereka kekuatan apa saja yang kamu sanggupi dan dari kuda-kuda yang ditambat untuk berperang (TQS. Al-Anfal:60).

Pemangku manajemen dalam organisasi diwajibkan untuk bersiap menghadapi setiap kemungkinan dengan memobilisasi kekuatan yang dimiliki agar mampu bertahan dan memenangkan kompetisi ataupun memanfaatkan ancaman seperti pandemic menjadi peluang baru dalam kegiatan organisasi. Perubahan lingkungan eksternal dapat menjadi ancaman sekaligus sebagai peluang. Strategi mengoptimalkan kekuatan untuk menghadapi ancaman dikenal dengan strategi S-T (strength for threat), yaitu dengan melakukan inovasi dan diversifikasi. Sedangkan strategi mengoptimalkan kekuatan untuk memanfaatkan peluang, S-O (strength for opportunity) dilakukan dengan kegiatan ekspansi dan agresivitas penetrasi pasar (Matnin, 2020:73).

Pimpinan paling bertanggungjawab dalam menyusun strategi organisasi. Setiap startegi atau kebijakan pokok organisasi harus didasarkan pada data empiris dan melibatkan seluruh elemen dalam organisasi secara holistic. Selanjutnya

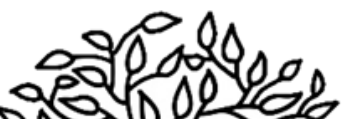




\section{"}

disusun kembali orientasi, kapitalisasi, formulasi, strukturisasi, dan aktualisasi seluruh program untuk beradaptasi dengan normal baru.

\section{Strategi Baru di Era Normal Baru}

Menghadapi dinamika perubahan eksternal harus dengan strategi yang dinamis. Normal baru adalah era yang belum pernah dibayangkan sebelumnya oleh kebanyakan orang. Meskipun perkembangan teknologi digital sudah terlebih dahulu menjadi tren dalam kehidupan yang dikenal dengan istilah era digital atau era milenial, akan tetapi desain interaksi masyarakat dalam pola physical distancing yang memaksa kita untuk mengoptimalkan pemanfaat teknologi digital dalam setiap aktivitas belum pernah terwacanakan. Di sisi lain, kita juga sangat bersyukur, bahwa perkembangan teknologi digital dan media social sangat membantu mengatasi keadaan sulit saat pandemic berlangsung. Wabah covid-19 muncul saat manusia telah menguasai teknologi digital. Manusia hanya butuh mencari metode yang sesuai untuk persoalan di setiap masa, karena sebenarnya problem utama manusia sepanjang zaman relative sama, hanya saja sarana, media, dan caranya yang berbeda.

Setiap organisasi perlu memiliki tujuan atau orientasi yang jelas, modal yang memadai, standar operasional yang aplikatif, sumberdaya manusia yang kompeten, dan implementasi yang tepat sasaran. Kelima komponen tersebut merupakan kekuatan menghadapi fenomena normal baru akibat wabah covid-19 Yaitu kekuatan manajemen perubahan strategi organisasi yang adaptif. Strategi baru dalam normal baru yang bisa kita singkat dengan panca re-si, yaitu:

\section{Reorientasi}

Merumuskan ulang orientasi atau tujuan organisasi menjadi sangat penting dalam menghadapi perubahan. Jika

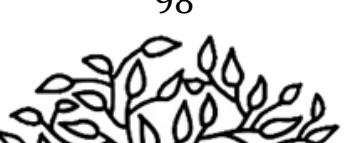


dirinci berdasarkan waktunya, maka organisasi memiliki tujuan jangka panjang, jangka menengah, dan pendek. Sedangkan berdasar visinya maka ada tujuan duniawi dan tujuan ukhrawi.

Tujuan dalam bahasa arab disebut sebagai niat atau alqasd. Tujuan adalah hal yang paling penting dalam melakukan suatu kegiatan, sehingga para ulama merincinya dalam satu pembahasan khusus yang dinamakan fiqih niat. Niat harus ada dalam setiap aktivitas karena semua feed back tergantung padanya, baik yang bervisi duniawi maupun ukhrawi. Sebagaimana disebutkan dalam hadits Rasulullah saw yang artinya: Sesungguhnya setiap perbuatan itu diberi ganjaran sesuai dengan niatnya, dan sesungguhnya setiap orang akan mendaparkan ganjaran sesuai dengan niatnya (HR. Al-Bukhari dan Muslim).

Tujuan dirumuskan dengan jelas agar memperoleh feed back yang sesuai harapan dalam jangka pendek, menengah, dan panjang. Tujuan yang jelas bersifat terukur, rasional, dan benar. Terukur memiliki makna sesuai dengan kemampuan sumberdaya organisasi, sebab Allah swt tidak membebankan kepada manusia sesuatu yang tidak mampu dilakukannya. Tujuan juga harus rasional, yaitu sesuai dengan sunnatullah atau memperhatikan kausalitas. Tujuan dikatakan benar jika sejalan dengan ridha dari Allah swt, sebagaimana firmanNya: Dan perumpamaan orang-orang yang membelanjakan hartanya karena mencari keridhaan Allah dan untuk keteguhan jiwa mereka (TQS. Al-Baqarah:265).

Juga di ayat yang lain: Padahal tidak ada seorang pun memberikan suatu nikmat kepadanya yang harus dibalasnya, tetapi (dia memberikan itu semata-mata) karena mencari keridhaan Tuhannya Yang Mahatinggi (TQS. Al-Lail: 19-20).

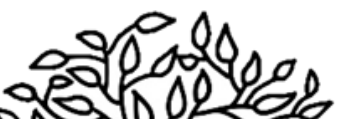




\section{| Panca Re-Si Manajemen Perubahan Strategi Baru di...}

Oleh karena itu pandemic perlu dijadikan sebagai momentum untuk merumuskan tujuan yang sesuai dengan kemampuan sumberdaya, kausalitas, dan keridhaan Allah swt. Reorientasi yang tidak hanya focus pada materi atau besarnya profit, tetapi juga memperhatikan nilai spiritual untuk mendapatkan keberkahan.

\section{Rekapitalisasi}

Setiap organisasi pasti memerlukan capital atau modal. Modal merupakan sarana dan sumber daya untuk melakukan kegiatan produksi yang dalam bidang keuangan juga disebut dengan asset. Rekapitalisasi adalah mengoptimalkan manfaat atau nilai setiap asset yang dimiliki oleh organisasi. Kadangkala organisasi memiliki banyak alternative sumberdaya yang dapat digunakan sehingga lalai untuk memanfaatkan sumberdaya secara optimal, seimbang, dan melakukan perawatan yang proporsional. Saat kondisi normal, terjadi inefisiensi pemanfaat sumberdaya karena dianggap perawatan asset mengganggu kinerja dan akselerasi organisasi dalam mencapai target. Akhirnya terjadi pemborosan, penelantaran asset, dan idle asset.

Hal tersebut merupakan pemborosan atau tabdzir yang dicela oleh Allah swt sebagaimana firman-Nya: Dan janganlah kalian menghambur-hamburkan (harta kalian) secara boros (TQS. Al-Isra':26). Islam juga mengajarkan agar memanfaatkan tanah (factor produksi) dengan baik. Rasulullah saw memberikan apresiasi kepada siapa saja yang telah memanfaatkan tanah: Siapa yang memakmurkan tanah yang tidak dimiliki oleh siapapun maka dia lebih berhak atas tanah tersebut (HR. Al-Bukhari).

Rekapitalisasi seluruh asset dan sumberdaya dilakukan agar terhindar dari pemborosan atau inefisiensi. Kalaupun terdapat asset yang sudah tidak bisa dimanfaatkan maka bisa

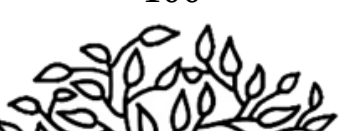


dialihkan kepada pihak yang membutuhkan, baik secara komersil maupun hibah.

\section{Reformulasi}

Reformulasi merupakan kebijakan untuk menetapkan kembali metode, cara, dan teknik organisasi dalam merealisasikan programnya. Kegiatan ini melibatkan ragam aktivitas, sarana, media, alat, dan teknologi. Aktivitas dan kreatifitas dalam merealisasikan program harus menyesuaikan dengan hokum perbuatan, sebagaimana dinyatakan dalam kaidah fiqih: hukum asal perbuatan manusia adalah terikat dengan syariat (Ismail, 2013:111). Sedangkan hukum asal media, sarana, dan teknologi adalah boleh atau mubah (Ismail, 2013:119).

Berdasarkan dua kaidah di atas maka dipahami bahwa setiap tujuan yang baik tidak boleh menghalalkan segala cara. Reformulasi yang tepat, yaitu selain tepat media dan sarana juga harus tepat caranya. Dibolehkan memanfaatkan semua sarana, media, dan teknologi yang tepat guna tetapi tetap memperhatikan nilai-nilai syariah atau halal-haram. Melalui kedua pendekatan pemanfaatan teknologi dan cara yang halal, maka citra organisasi meningkat. Peningkatan citra akan diikuti oleh peningkatan trust pada masyarakat sehingga usaha atau jasa milik organisasi akan diminati.

\section{Restrukturisasi}

Struktur organisasi merupakan bagian dari manajemen sumberdaya manusia. Personal tidak lagi dipandang sebagai factor produksi melainkan sebagai sumberdaya (resource) atau asset organisasi. Melalui pengembangan dan fasilitas penunjang sumberdaya manusia, diharapkan orientasi organisasi tercapai secara optimal (Nawawi, 2014:170).

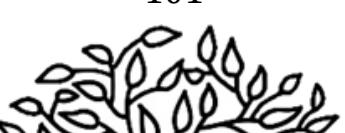




\section{* | Panca Re-Si Manajemen Perubahan Strategi Baru di...}

Terjadinya perubahan akibat pandemic, mengharuskan formulasi organisasi dilaksanakan oleh sumberdaya manusia (SDM) yang kompeten. Restrukturisasi diawali dengan human resources maintenance and development (pemeliharaan dan pengembangan SDM). Konten pengembangan harus diarahkan sesuai kebutuhan perubahan. Pimpinan dapat melakukan evaluasi kecenderungan dan keterampilan baru SDM. Selanjutnya akan mudah melakukan restrukturisasi yang tepat. Program ini meliputi seluruh pola pengembangan SDM, seperti; recruitment, mutation, routing, dan promoting.

\section{Reaktualisasi}

Aktualisasi adalah langkah organisasi dalam implementasi seluruh programnya. Sebagaimana dipahami bahwa dinamika di lapangan terkadang berbeda dengan konsep program yang telah dimatangkan. Maka pimpinan memiliki kewenangan untuk melakukan improvisasi.

Improvisasi menjadi dasar untuk menetapkan program yang relevan dan permanen di era setelahnya yaitu normal baru. Pada saat benar-benar keadaan menjadi normal, bisa saja program tersebut direaktualisasi kembali. Kunci utama akselerasi dalam melakukan reaktualisasi adalah kecepatan berfikir dan bertindak. Dalam hal ini dibutuhkan syarat utama yang harus dipenuhi oleh personal dalam organisai, yaitu semangat pembelajar. SDM pembelajar diharapkan mampu bereaksi secara cepat dan tepat terhadap perubahan.

Demikian dasar manajemen perubahan dalam masa normal baru. Di samping kemauan untuk melakukan perubahan juga dibutuhkan semangat belajar supaya strategi baru organisasi berjalan secara efektif. Oleh karena itu organisasi, khususnya para pimpinan harus menciptakan suasana kondusif bagi SDM di

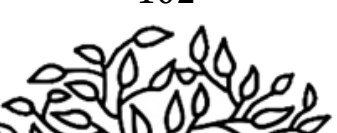


lingkungan organisasi guna menjamin keberhasilan strategi baru yang dimaksudkan.

\section{Daftar Pustaka}

Ismail, Muhammad. 2013. Bunga Rampai Pemikiran Islam. Jakarta: Gema Insani.

Kunaifi, Aang. 2016. Manajemen Pemasaran Syari'ah Pendekatan Human Spirit; Konsep, Etika, Strategi, dan Implementasi. Yogyakarta: Maghza Pustaka.

Matnin., Kunaifi, Aang. 2020. Manajemen Lembaga Keuangan dan Bisnis Islam. Pamekasan: Duta Media.

Nawawi Uha, Ismail. 2014. Manajemen Perubahan: Teori dan Aplikasi pada Organisasi Publik dan Bisnis. Bogor: Ghalia Indonesia.

Sulaiman Al-Asyqar, Umar. 2006. Fiqih Niat. Jakarta: Gema Insani.

Yunia Fauzia, Ika., Kadir Riyadi, Abdul. 2014. Prinsip Dasar Ekonomi Islam Perspektif Maqashid al-Syari'ah. Jakarta: Kecana Prenadamedia Group. 
* | Panca Re-Si Manajemen Perubahan Strategi Baru di... 


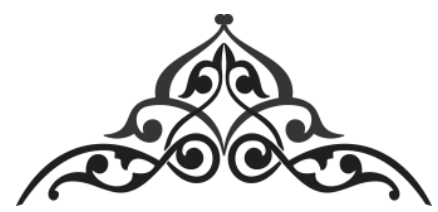

STRATEGI MANAJEMEN DALAM

MENGHADAPI PERUBAHAN DAN KRISIS DI

MASA PANDEMI

\title{
Dedeh Afifah, S.Pd, M.M, CSTMI ${ }^{1}$ \\ Universitas Islam 45
}

\begin{abstract}
"Prinsip ekonomi yang baik adalah menjawab apa yang dibutuhkan oleh masyarakat, sehingga strategi seperti peralihan usaha adalah salah satu strategi yang bisa dilakukan manajemen perusahaan agar mampu bertahan di era pandemi"
\end{abstract}

\section{A. Pendahuluan}

Derusahaan sebagai organisasi yang berorientasi pada keuntungan financial secara de facto merupakan tempat bergantung para karyawan. Kuatnya suatu perusahaan berdiri di topang oleh manajemen yang bagus dalam pengelolaannya, baik dari segi penempatan yang tepat sumber daya manusianya ataupun pemilihan yang sesuai untuk sumber daya alam dan prasarana yang dibutuhkan. Kekuatan tersebut juga di dukung oleh cepatnya perusahaan dalam menangkap sinyal perubahan secara eksternal, sebagai langkah antisipasi terhadap krisis

1 Dedeh Afifah lahir di Pemalang pada tanggal 22 November 1979, Dosen di Universitas Islam 45 dan Universitas Dian Nusantara. Menyelesaikan Sarjana Pendidikan Ekonominya pada tahun 2004 di Universitas Negeri Jakarta dan Mendapatkan gelar Magister Manajemen tahun 2010 di Universitas Suryadarma. Penulis mempunyai pengalaman mengajar selama kurang lebih 15 tahun di beberapa kampus sebelumnya antara lain UBSI, LP31, Pranata Indonesia dan STIE Wira Bhakti Jakarta. Penulis juga mempunyai Sertifikat Asessor dan Sertifikat Kompetensi Keahlian untuk bidang Administrasi Profesional dari BNSP. 


\section{4ै | Strategi Manajemen dalam Menghadapi Perubahan...}

global ataupun perubahana karena factor lainnya. Seperti yang terjadi saat ini, yaitu adanya musibah pandemi yang disebabkan oleh covid 19

Pandemic ini menyebabkan banyak factor terdampak. Pemerintah banyak mengeluarkan kebijakan-kebijakan baru, dimulai dari adanya Pembatasan Sosial Berskala Besar (PSBB) yang menyebabkan dibatasinya banyak sektor, terutama sektor ekonomi. Mulai dari pembatasan trasnportasi, pembatasan jumlah pekerja, pembatasan jalur pendistribusian dan penutupan pasar-pasar modern seperti mall atau pun tempat rekreasi keluarga.hal ini tentu saja memgakibatkan perusahaanperusahaan yang bergerak pada bidang tersebut menjadi mengalami kendala-kendala finansial karena terhambatnya proses pemasaran produksi.

Tidak sedikit perusahaan yang tidak siap terhadap perubahan yang terjadi. Yang akhirnya menyebabkan krisis berkelanjutan dalam usahanya. Pandemi covid 19 ini adalah salah satu keadaan yang pastinya tidak pernah terbayangkan sebelumnya. Perlu strategi yang tepat dalam menanggulangi krisis yang terjadi di perusahaan. Cara yang paling tepat sebenarnya adalah membuat planning untuk menghadapi krisis yang dapat diprediksikan sebelumnya. Menurut AB Susanto dalam www.gartner.com diperkirakan hanya $85 \%$ dari perusahaan-perusahaan Global 2000 yang membuat rencana penanganan krisis dan hanya $15 \%$ saja yang menyusun rencana bisnis yang lengkap Fakta ini menunjukkan masih banyak bisnis yang belum memperhitungkan beragam krisis yang mungkin terjadi dalam perencanaan bisnis mereka. Hal ini membuktikan bahwa banyak perusahaan yang tidak siap terhadap krisis yang akan melanda. Padahal seyogyanya antisipasi ini masuk dalam blue print ketika perusahaan akan didirikan. Kesiapan atau ketidaksiapan perusahaan dalam menghadapi krisis bukanlah memvonis baik atau tidak baiknya kinerja manajemen dalam

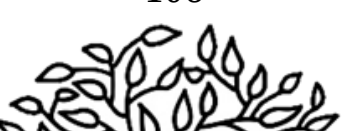


mengelolanya, karena banyak faktor yang mempengaruhi kondisi tersebut.

\section{B. Analisa Perubahan dan Krisis}

Para pemimpin perusahaan sesuai dengan peranan dan fungsinya sebagai manajer puncak mau tidak mau harus mempunyai kemampuan berpikir strategis, kemampuan melihat suatu permasalahan secara holistic dan sekaligus mampu mengantisipasi masa depan. Meskipun perkembangan dan perubahan yang terjadi di masa yang akan datang sulit untuk diprediksi bukan berarti kegiatan-kegiatan yang dilakukan bersifat reaktif saja. Dengan kemampuan berpikir strategis pemimpin dapat, menyiapkan rencana-rencana tindakan yang tepat berdasarkan hasil analisa yang menyeluruh terhadap keadaan dan potensi factor-factor internal dan eksternal perusahaan.

Menurut Minztberg dalam buku Prof. Dr. Billy Tunas (2012:2) strategi adalah suatu rencana, atau sesuatu yang equivalent dengan arah, petunjuk atau arah tindakan menuju masa depan atau suatu jalur untuk dapat mencapai ketujuan. Masih menurut minztberg strategi juga dapat dikatakan suatu pola yang konsisten dalam perilaku sepanjang waktu tertentu.

Cannon dalam buku Esensi Manajemen dan Perencanaan Strategik Billy Tunas (2012:5) mengungkapkan bahwa strategi bisnis yang efektif merupakan kebutuhan yang esensial bagi perusahaan yang berhasil pada masa kini dan masa depan. Strategi dapat dibentuk lewat suatu penafsiran dan prioritas faktor strategis yang mungkin akan berdampak terhadap semua keputusan besar yang mempengaruhi masa depan perusahaan.

Allison (Munir, 2008: 23) mengatakan bahwa strategi adalah arah atau pendekatan terpadu yang diambil oleh organisasi untuk menanggapi lingkungan, sehingga organisasi

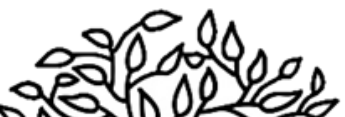




\section{| Strategi Manajemen dalam Menghadapi Perubahan...}

mampu mencapai tujuannya. Ini berarti suatu rencana tindakan berskala besar dalam berinteraksi dengan lingkungan untuk mencapai tujuan jangka panjang.

Manajemen menurut Siswanto (2007:1) yaitu seni dan ilmu dalam perencanaan , pengorganisasian, pengarahan, pemotivasian, dan pengendalian terhadap orang dan mekanisme kerja untuk mencapai tujuan. Krisis dalam ilmu ekonomi www.bukukita/ekonomi/manajemen.com adalah situasi yang merupakan titik balik (turning point) yang dapat membuat sesuatu tambah baik atau tambah buruk. Jika dipandang dari kaca mata bisnis suatu krisis akan menimbulkan hal-hal seperti berikut : Intensitas permasalahan akan bertambah. Masalah akan dibawah sorotan publik baik melalui media masa, atau informasi dari mulut ke mulut. Managemen Krisis diartikan sebagai sebagai persiapan dan pelaksanaan strategi dan taktik atau cara yang dapat mencegah atau mengatasi dampak masalah-masalah penting dalam perusahaan atau organisasi. Managemen krisis berarti cara berfikir dan bertindak pada saat semuanya menjadi keruh dan kacau. Perbaikan krisis membutuhkan semua kemampuan dan ketrampilan yang kita miliki, dengan situasi dibawah tekanan dan dengan waktu yang relative singkat dalam penyelesaiannya, karena pada umumnya menyangkut kepentingan bersama atau orang banyak.

Kondisi lingkungan usaha menjadi semakin sulit diprediksi secara linier, karena memang fenomena linieritas sudah tidak ada lagi di dalam lingkungan bisnis yang semakin ganas. Penetrasi variable eksternal ke dalam sistem organisasi perusahaan, hanya mungkin ditanggapi dengan baik bila pengelolaan usaha tidak lagi ada dasar business as usual. Mempertahankan diri untuk tetap exist dan survive dalam lingkungan usaha yang bergejolak bukan persoalan mudah. Menurut De Geus, pakar Strategic Management dan Bisnis Internasional dari London Business School (majalah Usahawan

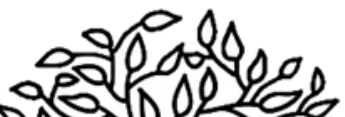


No.05 XXVII Mei 1998) mengemukakan alasan mengapa perusahaan yang ada kini tidak mampu mempertahankan kelangsungannya. Perusahaan-perusahaan tersebut di tengah dinamisnya perubahan tidak mampu membaca, menangkap, dan mengidentifikasi sinyal-sinyal perubahan. Oleh karena itu ketika perubahan itu benar-benar terjadi, mereka tak siap menghadapinya karena struktur internalnya memang terlambat dan tak mampu melakukan penyesuaian.

Perusahaan-perusahaan tersebut bubar dan berakhir karena pihak manajemen perusahaan-perusahaan tersebut hanya memfokuskan diri dan terbelenggu secara sempit pada pemikiran ekonomi. Masih menurut De Geus, gagalnya perusahaan mengidentifikasi perubahan tersebut setidaknya disebabkan oleh tiga alasan.Pertama, karena hakekat perusahaan sesungguhnya merupakan kumpulan manusia, maka secara psikologis manusia sendiri memang punya resistensi untuk berubah.. Kedua, sinyal perubahan tak terbaca dan teridentifikasi karena perusahaan memang belum terbiasa dan belum berpengalaman terhadap gejala perubahan itu sendiri. Ketiga, kegagalan perusahaan menangkap sinyal perubahan karena memory of the future dari banyak perusahaan memang tidak terlatih untuk membuat dan menyimpan berbagai alternatif tindakan. Manajemen perusahaan sudah sangat terbiasa dengan pola pikir mekanis dengan menganut pemikiran manajemen rationalist dimana arah perusahaan seakan mudah ditentukan berdasarkan hasil analisa lingkungan (SWOT).

\section{Strategi Manajemen dalam Menghadapi Pandemi}

Mengamati semakin banyaknya perusahaan yang tumbang belakangan ini, memberikan sinyal mengenai bagaimana manajemen perusahaan hanya mempersepsikan perusahaan sebagai mesin ekonomi belaka. Oleh karena itu diperlukan suatu agenda reformasi bagi manajemen perusahaan pasca krisis,

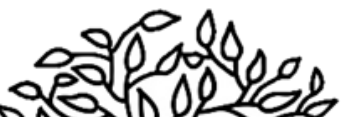



Strategi Manajemen dalam Menghadapi Perubahan...

dengan beberapa langkah alternative yang memungkinkan. Pertama,orientasi manajemen perusahaan harus berubah. Jika keadaan perusahaan masih harmonis dengan keadaan lingkungannya maka tugas utama manajemen adalah berusaha terus mengejar laba untuk kemudian tumbuh menjadi besar. Esensi manajemen dalam konteks ini adalah alokasi efektif dari sumberdaya yang dimiliki perusahaan kepada tempattempat yang memungkinkan munculnya maksimalisasi keuntungan. Akan tetapi jika sebaliknya yang terjadi, dimana keadaan lingkungan menjadi sangat bergejolak atau tercipta keadaan krisis seperti saat ini, kebijakan manajemen perusahaan harus bergeser secara mendasar, dari memburu keuntungan untuk tumbuh, menjadi bagaimana menyelamatkan diri untuk tetap exist dan survive. Kedua, manajemen perusahaan harus memandang perusahaan tidak lagi sebagai mesin ekonomi belaka yang hanya berfungsi sebagai penghasil barang dan jasa demi maksimalisasi keuntungan segelintir pemilik perusahaan. Manajemen perusahaan harus memandang perusahaan sebagai suatu entitas hidup yang menyediakan banyak ruang bagi manajemen untuk berimprovisasi.

Lalu Bagaimana perusahaan di Indonesia mengantisipasi adanya covid 19 ini agar perusahaan tetap mampu berdiri dan berkembang. Beberapa antisipasi yang coba dilakukan pihak manajemen dalam menyesuaikan kebijakan yang ditetapkan pemerintah diantaranya adalah, pertama memberlakukan sistem kehadiran karyawan dengan dibuat masuk beberapa hari dan di bershift, hal ini dilakukan untuk mengantisipasi adanya pengurangan karyawan, yang disebabkan karena menurunnya jumlah permintaan produk di pasaran. Selain itu hal lain yang dilakukan agar cash flow tetap bertahan manajemen melakukan "tabungan" dari gaji karyawan. Namun biasanya yang berdampak diteapkannya tabungan tersebut adalah top manajemen yang mempunyai salary yang cukup besar. Dengan

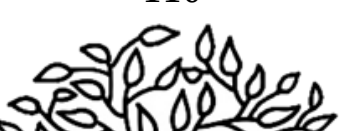


itikad baik jika perusahaan kembali berjalan normal tabungan tersebut akan dikembalikan. Apakah hal tersebut memungkinkan untuk dilakukan? Mungkin akan terdengar sulit, tapi mengingat pentingnya bertahan dalam kondisi pandemi saat ini dimana bertahan adalah pilihan yang tidak dapat dielakkan dari pada perusahaan menemui ajalnya adalah salah satu pilihan yang bisa diterapkan.

Alternatif bertahan lainnya yang bisa dijadikan pilihan adalah melirik usaha lain yang menjadi kebutuhan paling di cari masyarakat pada saat ini, misalmya memproduksi masker dengan model dan bahan yang lebih menarik namun tetap aman, memproduksi Alat pelindung Diri (APD), memproduksi sarung tangan, memproduksi dan menjual hand satitizer, bahkan sekarang muncul masker dengan bahan baku plastik yang kita kenal dengan nama face shield.

Peralihan usaha ini menjadi alternatif yang bisa dipertimbangkan, mengingat prinsip ekonomi yang baik adalah menjawab apa yang dibutuhkan oleh masyarakat. Secara umum peralihan usaha tersebut memang tidak bisa dilakukan oleh sebagian besar perusahaan, misalnya untuk perusahaanperusahaan elektronik, perusahaan furniture, perusahahaan otomotif, tetap harus berpikir keras untuk bertahan, salah satunya dengan me-rolling kerja para karyawannya, melempar produk ke luar negeri atau mencoba melebur dengan perusahaan lain untuk menciptakan produk lain yang tetap di cari masayarakat. Misalnya dengan menjamurnya kegiatankegiatan secara online, perusahaan elektronik bisa memanfaatkan kondisi tersebut dengan menyediakan sarana mendukung, antara lain kebutuhan IT.

Gambaran alternatif dan peralihan usaha tersebut adalah beberapa strategi yang bisa dilakukan manajemen perusahaan agar mampu bertahan di era pandemi ini, meski tidak menjadi pilihan mutlak namun setidaknya itulah yang sudah atau

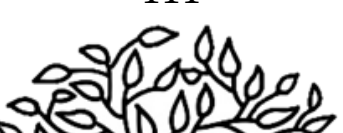


| Strategi Manajemen dalam Menghadapi Perubahan...

mungkin yang akan coba dilakukan beberapa pengusaha yang ada di Indonesia. Semoga catatan kecil ini mampu menginspirasi dan membantu memberi solusi lain dalam bertahan.

\section{DAFTAR PUSTAKA}

Billy Tunas, M.Sc, Dr, 2012 Esensi Manajemen dan Perencanaan Strategik. Jakarta: Universitas Suryadarma.

Chatra. Emeraldy, Nasrullah Rulli. 2008. PR: Strategi Kehumasan dalam Menghadapi Krisis. Bandung: Multi Trust Creative Service.

Hanni Handoko.201. Manajemen. Yogyakarta. BPFE Yogyakarta. Munir Ningky. 2008. Knowledge Management Audit : Pedoman Evaluasi Kesiapan Organisasi Mengelola Perusahaan, Jakarta: PPM.

Ruslan. Rosady, SH, MBA, 2008 Praktek dan Solusi PR dalam Situasi Krisi dan Pemulihan Citra. Jakarta: Ghalia Indonesia.

Siswanto, M.Si, Dr. 2007. Pengantar Manajemen. Jakarta: Bumi Aksara.

www.ekonomidunia.blogspot.com

www.gartner.com

www.ronawajah.blogspot.com

www.bukukita/ekonomi/manajemen.com

Majalah Usahawan No.06 XXVII Mei 1998.

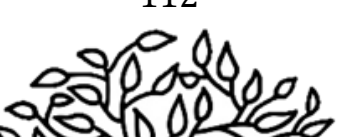




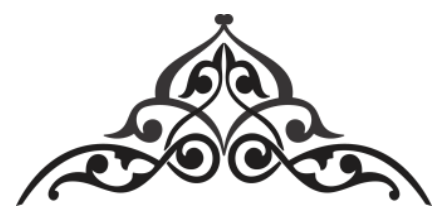

\section{URGENSI SELF MANAGEMENT DALAM MENGHADAPI GONCANGAN BELAJAR DI ERA PANDEMI COVID-19}

\section{Sri Wahyuni, M.Pd ${ }^{1}$ UNUSIA Jakarta}

"Self management sama hal nya membangun mental, pondasi, dan benteng pertahanan ketika dihadapkan dengan persolan. Dengan Self management, individu memiliki amunisi dan strategi untuk bertahan dimasa sulit"

Kemunculan virus Corona di kota Wuhan China pada IDesember 2019 yang lalu, dengan proses penularannya yang begitu cepat dan masif ke seluruh penjuru dunia, seakan membuat planet yang dihuni oleh manusia ini menjadi tergoncang dengan dahsyatnya. Terlebih WHO (World Health Organization) menyatakan darurat virus corona dengan mengeluarkan pernyataan bahwa virus Corona sebagai pandemi yang kemudian dinamai Corona Virus Desease 19 (Covid-19). Hampir seluruh Negara di dunia terkena dampak dari Covid-19 tersebut dan telah menimbulkan berbagai permasalahan hidup yang begitu pelik pada masyarakat dunia tak terkecuali di Indonesia. Tatanan kehidupan masyarakat yang mulanya

1 Sri Wahyuni lahir di Demak, 5 September 1990. Penulis merupakan dosen di UNISIA Jakarta. Penulis menyelesaikan jenjang S1 dan S2 di Universitas Wahid Hasyim Semarang. 


\section{| Urgensi Self Management dalam Menghadapi Goncangan..}

berjalan dengan normal dan begitu nyaman untuk dijalani, seketika menjadi porak poranda, ada rasa ketakutan, kecemasan, dan bahkan mengakibatkan penderitaan pada sebagian masyarakat yang terdampak.

Pemerintah Indonesia mengambil langkah pembatasan jarak/fisik (Physical Distancing) sebagai upaya untuk menghambat penularan Covid-19 dalam skala besar. Sehingga dengan diterapkannya langkah tersebut (Physical Distancing) membawa pengaruh tersendiri pada berbagai sektor, baik sektor kesehatan, sosial, ekonomi, dan pendidikan.

Pada sektor pendidikan, seperti yang kita ketahui sejak diterapkannya sistem belajar jarak jauh (Learn From Home), mengakibatkan goncangan tersendiri dalam bidang pendidikan. Kegiatan belajar mengajar menjadi tidak optimal, proses transfer ilmu yang diberikan oleh pendidik kepada peserta didik menjadi tersendat, kegiatan praktikum sejenak terhenti, ditambah lagi pembelajaran secara daring banyak menemui kendala, baik karena koneksi yang tidak mendukung, mahalnya kuota yang harus dibeli oleh peserta didik, penugasan yang tidak sesuai dan bahkan dianggap terlalu memberatkan peserta didik sehingga mengakibatkan kegoncangan mental yang berdampak pada motivasi dan semangat belajar siswa yang justru menurun.

Pada kondisi seperti saat ini sangat dibutuhkan sistem pengelolaan diri yang diaktualisasikan dengan tindakan nyata serta didukung dengan penguatan mental spiritual, motivasi diri, dan peran peserta didik sebagai individu yang mandiri dengan mengupayakan berbagai usaha yang dapat membangkitkan semangat belajar, dan bertanggung jawab pada dirinya sendiri sebagai penuntut ilmu. Komalasari dalam Isnaini dkk ( 2018 : 24) mendefinisikan self management sebagai prosedur pengaturan perilaku oleh individu sendiri. Sehingga dapat disimpulkan bahwa self management merupakan langkahlangkah yang diambil oleh setiap individu dalam mengatur

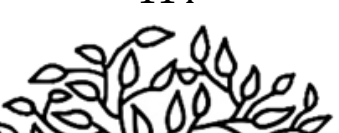


dirinya sendiri. Kaitannya dengan kegiatan belajar, seorang individu mempunyai langkah dan strategi sendiri dalam menentukan kegiatan belajarnya.

Selanjutnya Prijosaksono dkk dalam Rifai dkk (2018 : 26) mengungkapkan tujuan dari pengelolaan diri adalah mempersiapkan diri untuk menghadapi perubahan. Perubahan bisa mengarah pada beberapa hal,baik perubahan ekonomomi, situasi, kondisi, dan perubahan lainnya termasuk didalamnya adalah perubahan yang diakibatkan oleh Covid-19 yang sekarang ini terjadi.

Prijosaksono dan Sembel (2002 : 5) mengungkapkan ada enam cara untuk menyikapi perubahan yang perlu ditanamkan dalam diri individu, diantaranya:

1. Menerima apa pun situasi atau krisis yang melanda

2. Senantiasa berharap dan memiliki keyakinan kuat bahwa segala sesuatu ada waktunya

3. Fokus pada kekuatan dan peluang bukannya pada kelemahan atau musibah yang dihadapi. Sikap ini dapat menuntun kita untuk dapat mengatasi ketakutandan bergerak keluar dari zona depresif menuju kearah yang kita inginkan.

4. Kemauan belajar dari pengalaman

5. Mengembangkan rasa syukur atas musibah yang dialami

6. Mengembangkan sikap aktif dalam mengambil bagian untuk mengatasi krisis dan mengendalikan perubahan yang terjadi.

Sebagai manusia biasa memang benar kita tidak bisa menolak keberadaan Covid-19 yang sedang melanda negeri ini, kita hanya bisa menerima, tetapi bukan berarti kita pasrah, akan tetapi kita harus mempunyai upaya bagaimana bisa menjaga diri dalam mengatasi situasi yang penuh kegoncangan dan ketidak pastian ini. Harapan akan selalu ada bagi mereka yang mau berusaha dan mempunyai optimisme hidup serta dibarengi

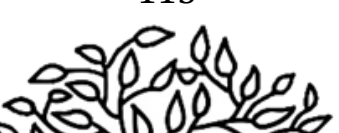




\section{" | Urgensi Self Management dalam Menghadapi Goncangan..}

dengan keyakinan yang diwujudkan dalam keimanan. Sebagai manusia yang dibekali dengan akal dan ilmu sudah selayaknya kita menanamkan jiwa optimisme dalam menghadapi situasi apapun, karena kita tahu bahwa Tuhan tidak akan menguji hamba-Nya diluar batas kemampuannya.

Seperti yang kita tahu bahwa pendemi tidak terjadi pada saat ini saja, akan tetapi pada tahun-tahun yang jauh sebelumnya, dunia juga sudah pernah mengalami musibah pandemi. Lalu apa mereka hancur? Jawabannya tidak, justru dengan pandemi tersebutlah menjadikan suatu negara menjadi lebih berkembang dan produktif dalam upaya menyelesaikan pandemi tersebut. Mereka mengembangkan ilmu pengetahuan dan teknologi dalam rangka menemukan obat sebagai penawar melalui peluang yang ada. Sejalan dengan hal tersebut, dengan kejadian pandemi ini kita banyak belajar tentang pengetahuan dan teknologi salah satu contohnya adalah melalui pembelajaran daring kita mengenal produk dan penggunaan teknologi berupa aplikasi video conference dan sejenisnya. Padahal sebelumnya kita tidak pernah tahu akan keneradaan fungsi dan penggunaan aplikasi tersebut. Kejadian ini mengajarkan kepada kita, bahwa belajar tidak mengenal waktu, tempat, situasi dan kondisi, dan bahkan sumber belajar itu sendiri.

Pada hakekatnya, belajar tidak hanya dilakukan di lembaga formal seperti sekolah yang dituntun oleh guru maupun dosen sebagai sumber belajar. Guru dan dosen hanyalah salah satu dari sumber belajar yang ada, sebenarnya kalau kita mau mengeksplor diri kita masih banyak sumber belajar lain, apalagi di era 4.0 yang serba digital mempermudah kita untuk mengakses segala informasi yang kita butuhkan dan bahkan mampu memberi jawaban apa yang ingin kita ketahui termasuk pada ranah pengetahuan bidang pendikan.

Arah tujuan belajar kita yang menentukan. Yang bisa memahami, mengendalikan dan mengatur diri adalah kita

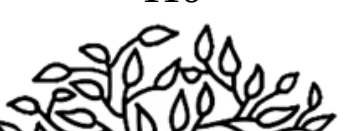


sendiri. Konsep pengelolaan diri menjadi tanggungjawab kita sendiri mulai dari yang pertama menentukan tujuan belajar, kita harus tahu apa yang menjadi tujuan belajar kita, sehingga kita bisa merancang dan merencanakan langkah-langkah dan strategi untuk mewujudkan atau mencapai tujuan tersebut. Kedua pengelolaan waktu, disini kaitannya dengan kedisiplinan. Sebisa mungkin kita membuat perkiraan waktu kapan tujuan yang telah kita rencanakan dapat tercapai, tentunya dengan mengatur waktu dan penjadwalan belajar yang baik. Ketiga strategi belajar, Penerapan pembelajaran jarak jauh dengan sistem daring membuat kita mau tidak menjalani belajar mandiri dan membutuhkan strategi khusus supaya kegiatan belajar tidak berhenti. Kita bisa bisa menentukan dan memilih model dan metode belajar yang sesuai dengan mood dan kebutuhan kita tanpa dibatasi tempat, waktu dan teori tertentu. Keempat pola pikir kita dalam menjalani kehidupan ini, terutama pola pikir tentang arti belajar buat kita. Kita harus memahami bahwa belajar bukanlah tuntutan orang tua maupun tuntutan prasyarat untuk mencari pekerjaan, akan tetapi berfikirlah bahwa dengan belajar kita bisa mengerti tentang hakekat kehidupan ini, dengan belajar yang awalnya kita tidak tahu menjadi tahu, yang awalnya tidak tahu mana yang benar dan mana yang salah menjadi bisa membedakannya, yang awalnya tidak terarah menjadi terarah. Kelima konsistensi, semua tidakan postif yang kita lakukan harus dibarengi dengan konsistensi atau istiqomah dan berkelanjutan (continue). Kita tidak bisa menjalankannya hanya dalam beberapa jam, hari atau bulan saja, akan tetapi pada hakekatnya belajar adalah kegiatan yang ditempuh sepanjang masa.

Self management mempunyai pengaruh penting terhadap tanggungjawab belajar siswa, terlebih pada masa pandemi ini. Sebagaimana Heriansyah dan Kurniawan (2017) dalam penelitiannya menungkapkan bahwa ada bebrapa faktor yang

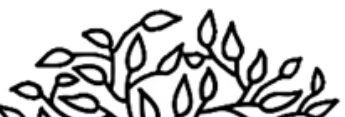




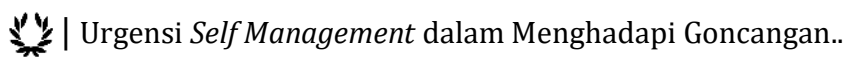

dapat meningkatkan tanggungjawab belajar diantaranya pertama mahasiswa mampu mengatur waktu belajarnya dengan membuat jadwal belajar sehingga mereka dapat belajar dengan baik, kedua mahasiswa mampu menyusun metode belajar yang mereka sukai sehingga belajar bukan lagi menjadi beban, tetapi menjadi bagian dari yang mereka sukai, ketiga mampu menyusun strategi dalam mengerjakan tugas yang diberikan oleh dosen sehingga dapat dikerjakan dengan tuntas dan sungguhsungguh, keempat komitmen untuk menghargai aturan-aturan yang berlaku. Ini berarti bahwa pengelolaan diri (self management) pada mahasiswa mempunyai peran penting atau urgensi terhadap tanggungjawabnya sebagai pembelajar dalam mengemban tugasnya.

Mahasiswa adalah orang yang sedang mencari ilmu, sudah selayaknya bersikap aktif dan produktif dalam menjalankan peran dan tugasnya yang berorientasi pada tujuan belajarnya. Pada dasarnya orang yang mencari ilmu itu adalah orang yang butuh akan ilmu, orang yang butuh tidak akan menganggap apa yang ia cari sebagai beban dan tanggungjawab, akan tetapi sebagai suatu kebutuhan yang ahru ia penuhi. Dengan demikian tanpa ditugaskan, tanpa disuruh, ia akan sudah punya inisiatif sendiri, punya cara dan jalan sendiri untuk mendapatkan apa yang ia cari. Inilah pentingnya sistem pengelolaan diri yang harus dimiliki oleh masing-masing peserta didik diera pandemi ini.

Penerapan self management sama hal nya membangun mental, pondasi, dan benteng pertahanan bagi mahasiswa sebagai individu ketika dihadapkan dengan berbagai macam persolan. Mereka mempunyai amunisi untuk bertahan dimasa sulit serta mempunyai strategi untuk menyelesaikan masalah yang dihadapi.

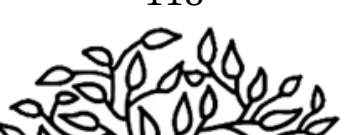




\section{Daftar Pustaka}

Heriansyah, Masnurrima dan Kurniawan, Dydik. 2017. Bimbingan Kelompok dengan Teknik Self Management untuk Meningkatkan Tanggung Jawab Belajar Mahasiswa. Jurnal Penelitian Pendidikan Indonesia. 2017 April 2; 5(2): $2477-3921$

Isnaini, Faiqotul dan Rifai, Muh. Ekhsan. 2018. Strategi Self Management untuk Meningkatkan Kedisiplinan Belajar. Sukoharjo: CV Sindunata

Prijosaksono, Ariwibowo dan Sembel Roy. 2002. Self Management Series (Control Your Life). Jakarta: PT Elex Media Computindo. 
| Urgensi Self Management dalam Menghadapi Goncangan.. 


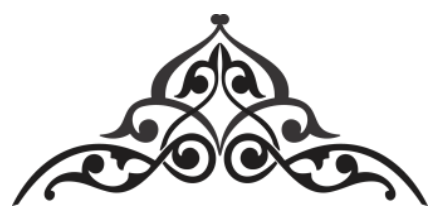

\section{MENYIASATI KEUANGAN PERUSAHAAN MENGHADAPI COVID 19}

\section{Edwin Hutauruk, SE., MM ${ }^{1}$}

"Banyak metode perusahaan untuk tetap bertahan dalam pandemi, di antaranya membuat Stress-Test, Cash Flows Management : Cost Efficiency and Tax Management, melakukan strategi pendanaan dan komunikasi yang tepat dalam Laporan Keuangan"

\section{A. DAMPAK GLOBAL COVID-19 PADA KINERJA KEUANGAN}

$\mathrm{V}$ irus Corona/COVID-19 merupakan pandemi yang melanda seluruh dunia. Menurut Direktur IMF Kristalina Georgieva (2020) "ekonomi dunia sedang mengalami resesi yang disebabkan oleh pandemi Covid 19", sedangkan menurut PwC's COVID-19 CFO Pulse Survey, Maret 2020 menunjukan bahwa "sebagian besar responden (yakni 150 finance leaders) berpandangan bahwa pandemi covid 19 berdampak signifikan terhadap bisnis mereka termasuk didalamnya pendapatan dan laba yang menurun."

Hampir seluruh sektor industri terimbas pandemi ini, terutama bidang manufaktur, perdagangan, energi dan

1 Edwin Ronald Hutauruk lahir di Jakarta, 14 April 1978, penulis menyelesaikan gelar Sarjana Ilmu Manajemen Keuangan di STIE YAI Jakarta (2002), sedangkan gelar Magister Manajemen diselesaikan di Universitas Mercu Buana (2018). 


\section{| Menyiasati Keuangan Perusahaan Menghadapi Covid 19}

transportasi, pariwisata, sektor perbankan dan perusahaan pembiayaan. Dampak pada sektor perbankan adalah meningkatnya risiko nonperforming loan (NPL) atau kredit macet para nasabahnya hal ini jelas berdampak signifikan sekali terhadap struktur pendapatan dan piutang pada pembukuan bank. Sedangkan pada perusahaan yang memiliki pinjaman/ struktur biaya dalam mata uang asing pandemi ini sangat berdampak pada tergganggunya cashflow perusahaan dan memperburuk kondisi kesehatan \& likuiditas perusahaan.

Banyak perusahaan menerapkan pemberlakuan social distancing dan work from home (WFH) yang juga berdampak pada perusahaan seperti penurunan produktifitas karyawan yang pada akhirnya akan berdampak pada pendapatan perusahaan.

\section{B. KEBIJAKAN BERTAHAN DARI DAMPAK COVID-19}

Banyak metode dan cara agar perusahaan tetap dapat bertahan (survive) dari kondisi pandemi ini, menurut Pusat Pengembangan Fakultas Ekonomi Universitas Indonesia (PPA FEB UI), ada empat strategi yang bisa diterapkan oleh pimpinan perusahaan pada kondisi ini. Empat strategi tersebut adalah :

1. Membuat Stress-Test

2. Cash Flows Management : Cost Efficiency and Tax Management

3. Melakukan strategi pendanaan yang tepat

4. Melakukan komunikasi yang tepat dalam Laporan Keuangan

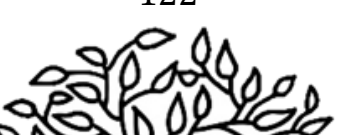


Empat strategi tersebut akan saya bahas satu persatu di bagian ini.

\section{Membuat Stress-Test}

Tujuan membuat stress-test ini adalah Teknik simulasi untuk mengidentifikasi area-area kerentanan dan kelemahan dalam bisnis sehingga dapat dirancang dan dimplementasikan rencana- rencana untuk mengatasinya secara cepat dan proaktif.

Langkah-langkahnya adalah :

a. Membuat beberapa skenario variabel penting dan memperkirakan dampaknya terhadap kinerja perusahaan, misalnya likuiditas.

b. Membuat opsi-opsi mitigasi berdasarkan berbagai kemungkinan (bisnis normal, dampak sedang, dampak berat).

c. Menyusun rencana strategis khusus untuk menanggapi krisis pandemi Covid-19

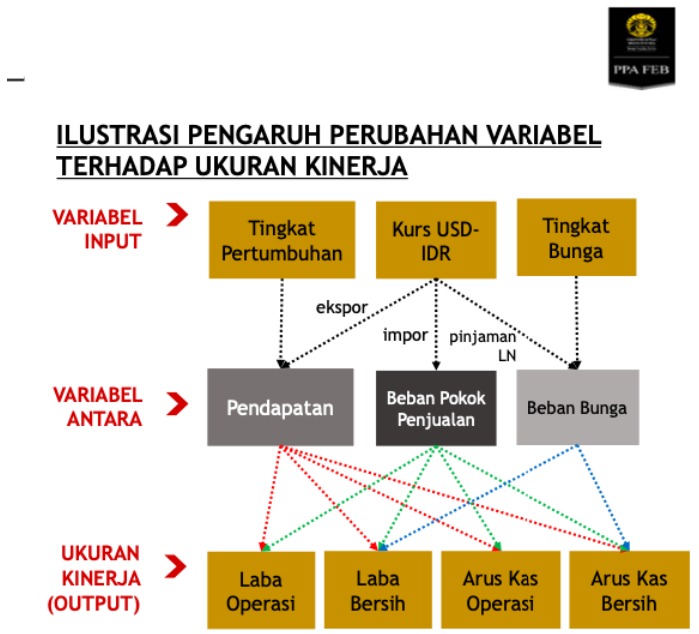

Asumsi: Selain variabel input, variabel lainnya dianggap tidak berubah.

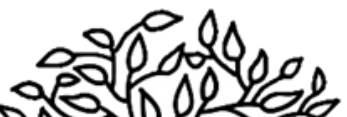




\section{Cash Flows Management : Cost Efficiency and Tax Management}

Perusahaan harus mulai menerapkan efisiensi biaya dan pajak dalam kondisi pandemi covid 19 saat ini. Contoh upaya upaya efisiensi biaya adalah : menunda rencana merger/akuisisi atau membatalkan investasi yang telah direncanakan, menutup sementara outlet/lini bisnis/produk yang kehilangan pelanggan, mengurangi biaya sewa kendaraan pada level tertentu manajemen dan beban utilitas, dan Mengurangi beban lembur, beban perjalanan dinas, dan menghindari pembayaran bonus dan dividen melalui utang.

\section{Melakukan strategi pendanaan yang tepat}

Strategi pendanaan merupakan salah satu upaya perusahaan agar dapat tetap bertahan hidup dalam kondisi pandemic seperti saat ini. Strategi pendanaan suatu perusahaan dibuat dengan pertimbangan bagaimana membentuk struktur pendanaan yang dapat meminimalkan biaya modal atau cost of capital. Sebagaimana diketahui, sumber pendanaan di dalam perusahaan mengandung biaya modal, diantaranya adalah utang yang mengandung biaya berupa bunga dan ekuitas seperti saham yang juga mengandung biaya, yaitu berupa dividen.

Trade off theory menyatakan bahwa perusahaan akan menggunakan utang, hutang akan memberikan tax saving tetapi hanya sampai titik tertentu dan setelahnya akan menimbulkan biaya financial distress dan biaya keagenan (agency cost) yang mengakibatkan turunnya nilai perusahaan (Fama, 2000). Financial distress atau tekanan keuangan muncul karena penggunaan utang yang berlebihan dalam struktur modal perusahaan, yang pada

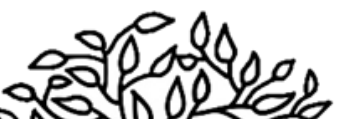


akhirnya akan dapat mengakibatkan meningkatkan risiko kebangkrutan (bankruptcy).

Groth dan Anderson (1997) menyatakan komposisi yang efisien dapat mengurangi biaya modal. Dengan menurunkan biaya modal secara langsung meningkatkan return bersih ekonomis dan meningkatkan nilai perusahaan. Menurut Hermanto (1999), komposisi yang optimal tersebut pada kenyataaannya dapat dicari secara trial and error berdasarkan pengalaman. Pendekatan tradisional menyatakan terdapat struktur modal yang optimal untuk setiap perusahaan (Sartono, 2001a:230; Hanafi, 2004:297). Pendekatan tradisional ini diwakili oleh dua teori yaitu teori static trade-off dan teori pecking order (Wibowo dan Erkaningrum, 2002). Teori static trade-off muncul karena penggabungan teori Modigliani-Miller yang memasukkan biaya kebangrutan dan biaya agensi. Hal ini mengindikasikan adanya trade-off antara penghematan pajak dari utang dan biaya kebangkrutan (Hanafi, 2004:311). Semakin besar proporsi utang maka semakin besar perlindungan pajak yang diperoleh. Di sisi lain, semakin besar proporsi utang maka semakin besar biaya kebangkrutan yang mungkin timbul. Dengan demikian, struktur modal yang optimal dapat dicapai dengan menyeimbangkan keuntungan perlindungan pajak dengan beban sebagai akibat penggunaan utang yang semakin besar (Sartono, 2001a:247). Teori static trade-off, secara teoritik memprediksikan bahwa leverage akan meningkat sejalan dengan 3 pemanfaatan utang dan menurun sejalan dengan bertambahnya biaya utang (Paramu, 2006) sementara teori pecking order mensyaratkan tidak terdapatnya suatu target debt equity ratio (Hanafi, 2004).

Pada kondisi pandemi Covid-19 ini, perusahaan perlu menyiasati Strategi Pendanaan yang lebih pas dan tepat

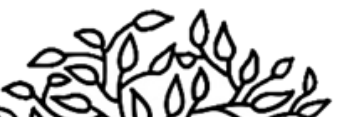


untuk menyelamatkan keuangan perusahaan. Ada dua kondisi keuangan perusahaan yang terjadi di masa pandemi saat ini, seperti :

1. Kondisi 1 yaitu situasi dimana arus kas tidak cukup untuk operasional perusahaan,

2. Kondisi 2 yaitu situasi dimana arus kas hanya cukup untuk mendanai aktivitas perusahaan.

Strategi yang perlu diterapkan oleh perusahaan dalam menghadapi dua kondisi tersebut diatas masing-masing memiliki pengertian yang berbeda yaitu :

Kondisi 1

a. Menunda penertbitan saham;

b. Manajemen dapat mempertimbangkan untuk melakukan refinancing atas utangnya dengan cara menerbitkan utang baru dengan tingkat bunga yang lebih rendah.

Kondisi 2

a. Manajemen perlu mempertimbangkan untuk berkomunikasi dengan kreditor agar dapat diberikan relaksasi atas pembayaran pokok atau bunga yang jatuh tempo.

\section{Melakukan komunikasi yang tepat dalam laporan keuangan}

Menurut PPA FEB UI dalam melakukan komunikasi yang tepat dalam laporan keuangan pada masa pandemic covid-19 ini perusahaan bisa mengacu kepada PSAK 8, 68, 71 dan pengungkapan lain, sebagaimana dijelaskan pada gambar berikut ini :

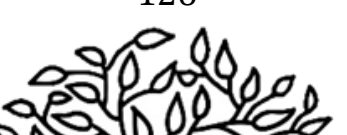




\section{STRATEGI 4: MELAKUKAN KDMUNIKASI YANG TEPAT DALAM LAPORAN KEUANGAN}

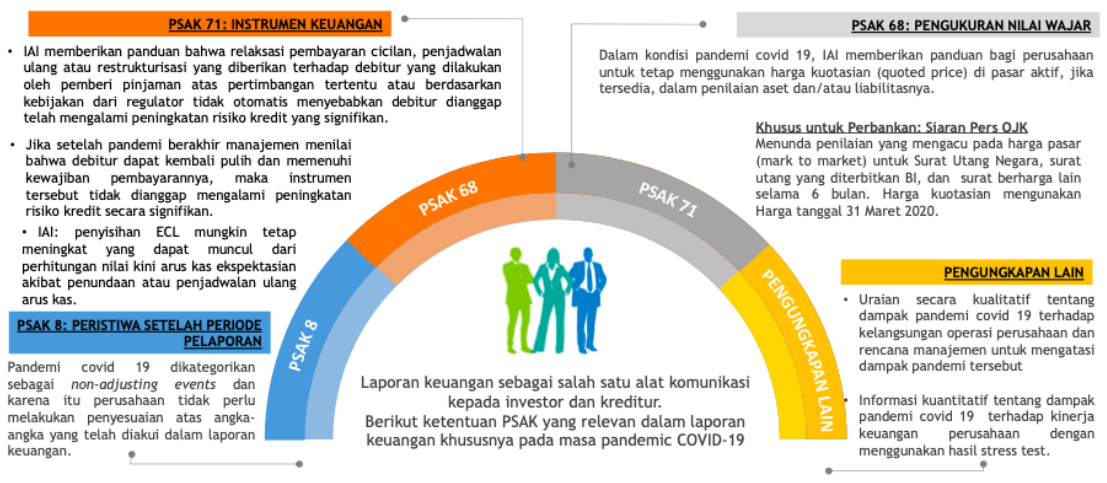

\section{DAFTAR PUSTAKA}

Fama, Eugene., French, Kenneth. 2000. Testing Tradeoff and Pecking Order Predictions About Dividends and Debt. CRSP Working Paper No. 506

Groth, J.C., Anderson, R.C. 1997. Capital Structure : Prespective for Managers. 35/7:552-561

Hermanto, B., 1999. Struktur Kapital : Antara Teori dan Praktek. XXVIII (3) : 56.

Wibowo, A.J., Erkaningrum, F.I., 2002. Studi Keterkaitan antara Dividend Payout Ratio, Financial Leverage, dan Investasi dalam Pengujian Hipotesis Pecking Order. Jurnal Ekonomi dan Bisnis Indonesia, 17 (4):506-519

Hackney, Anthony C. 2010. Stress and the neuroendocrine system: the role of exercise as a stressor and modifier of stress. Journal of Endocrinology \& Metabolism. Nov 1; 1(6): 783-792. Doi: 10.1586/17446651.1.6.783.

Patel, Harsh., Alkhawam, Hassan., Madanieh, Raef., Shah, Niel., Kosmas, Constantine E., and Vittorio, Timothy J. 2017.

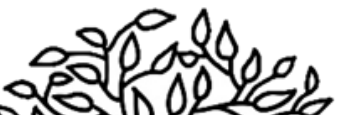


| Menyiasati Keuangan Perusahaan Menghadapi Covid 19

Aerobic vs anaerobic exercise training effects on the cardiovascular system. World Journal Cardiol. 2017 Feb 26; 9(2): 134-138. Doi: 10.4330/wjc.v9.i2.134

Sartono, A., 2001a. Manajemen Keuangan : Teori dan Aplikasi. Yogyakarta: BPFE.

Hanafi, M.M., 2004. Manajemen Keuangan. Yogyakarta: BPFE 


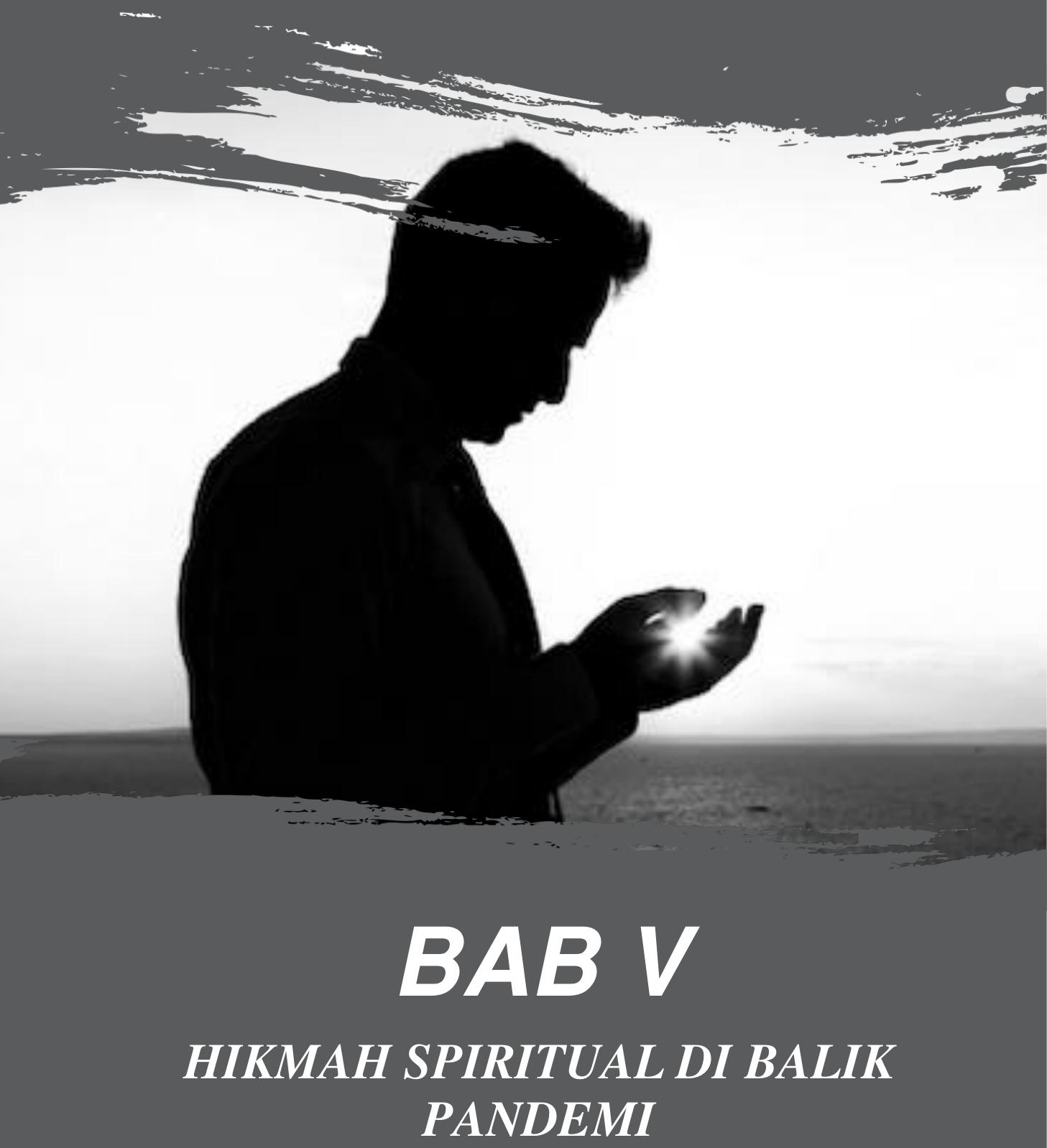




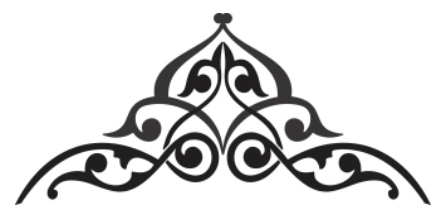

MENGURAI HIKMAH DIBALIK WABAH

\title{
Faliqul Isbah, M.Pd. ${ }^{1}$ \\ IAIN Pekalongan
}

\begin{abstract}
"Hikmah terbesar dibalik wabah ini adalah ketika keimanan dan ketakwaan kita kepada Allah semakin meningkat setelah ini, laku hidup kita terus diperbaiki baik jasmani maupun ruhani dan kesalehan kita pun semakin tinggi baik secara ritual maupun sosial."
\end{abstract}

\begin{abstract}
Corona Virus Disease 2019 atau COVID-19 adalah nama virus yang lebih dikenal dengan sebutan "korona", virus ini menjadi babak baru dalam sejarah peradaban manusia. belum ada satupun ahli yang mampu untuk menangkal virus ini secara medis, setidaknya penelitian-penelitian terkait vaksin untuk virus ini sampai saat ini belum membuahkan hasil. Virus yang bermula dari kota Wuhan di Cina tersebut, sekarang menyebar keseluruh penjuru dunia, sehingga keadaan ini ditetapkan sebagai pandemi global. Di Indonesia sendiri penyebaran virus ini mulai pada pekan pertama Februari 2020 dan sampai saat ini di Indoensia tidak kurang dari 54.000 jiwa terjangkit virus korona.
\end{abstract}

1 Faliqul Isbah lahir di Pekalongan, 05 Juni 1987, Penulis ${ }^{8}$ merupakan Dosen Bahasa Arab di IAIN Pekalongan, penulis menyelesaikan gelar Sarjana Pendidikan Bahasa Arab (PBA) di IAIN Syekh Nurjati Cirebon (2013), dan gelar Magister Pendidikan Bahasa Arab di Pasca Sarjana UIN Sunan Gunung Djati Bandung (2016). Selain aktif dalam bidang Pendidikan penulis juga aktif dalam bidang Pengabdian, organisasi masyarakat dan keagamaan. 


\section{"}

Pemerintah dan seluruh pihak tidak tinggal diam dalam menyikapi hal ini, berbagai macam upaya dilakukan mulai dari program social distancing, physical distancing, pembatasan sosial berskala besar (PSBB) dan terbaru new normal. Semua dilakukan pemerintah dan jajarannya untuk memutus mata rantai penyebaran virus korona. Relokasi anggaran dalam segala bidang dialihkan untuk pencegahan dan penanggulangan penyebaran virus, masyarakat mulai dari lapisan atas sampai bawah pun tidak lepas dari dampaknya, baik dalam bidang pendidikan, sosial, ekonomi, budaya, agama bahkan politik.

Misal dalam bidang pendidikan sendiri adanya wabah covid-19 ini memunculkan salah satu model pembelajaran baru yaitu online, dimana model ini sudah dilakukan sebelumnya oleh lembaga Pendidikan tertentu yang mengandalkan akses internet. Kampanye penyelenggaraan pendidikan berbasis online sejatinya sudah diupayakan jauh sebelum adanya virus korona, bahkan kita mengenal istilah Revolusi Industri 4.0 tentunya. Namun dengan adanya wabah ini hampir semua lembaga pendidikan baik formal, non formal dan informal mulai dari tingkat Dasar sampai Perguruan Tinggi melaksanakan kegiatan belajar mengajarnya melalui online dengan berbagai macam media yang tersedia.

Sedangkan dalam bidang Ekonomi, virus Korona memberikan dampak yang sangat hebat terhadap stabilitas ekonomi mulai skala Internasional sampai rumah tangga. Banyak pabrik, pengusaha, pedagang, karyawan dan buruh yang terpaksa harus gulung tikar atau setidaknya istirahat sejenak dari aktifitas kegiatan ekonominya, tentu hal ini berdampak pada kesulitan pemenuhan kebutuhan hidup masyarakat, utamanya golongan menengah ke bawah.

Dalam bidang Agama wabah ini juga memberikan dampak yang tidak diperkirakan sebelumnya, penutupan sementara tempat ibadah baik muslim dan non muslim diarahkan untuk

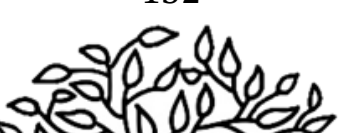


beribadah dari rumah masing-masing, bahkan pada saat bulan Ramadan umat Islam dihimbau untuk beribadah dari rumah, tarawih dari rumah, bahkan salat idul fitri dari rumah dan puncaknya adalah ketika Kementerian Agama RI memutuskan untuk membatalkan keberangkatan Jamaah Haji tahun 2020 karena wabah ini. Tentu segala hal yang berkenaan dalam bidang Agama tersebut bukanlah untuk kemudaratan bagi pemeluknya, malah justru ikhtiar Pemerintah demi keselamatan jiwa raga rakyatnya.

Apapun dampak 'negatif' yang terjadi karena wabah virus Korona ini, sebagai orang yang beriman dan bertuhan sudah seyogyanya kita untuk meyakini bahwa apa yang terjadi ini merupakan garis yang telah Allah Swt tentukan, terlebih jika kita menelaah lebih dalam bahwa pada prinsipnya semua musibah yang terjadi pada alam dunia ini sangat mungkin disebabkan oleh 'tingkah' manusia itu sendiri. Firman Allah Swt dalam Q.S. Ar Rum ayat 41 :

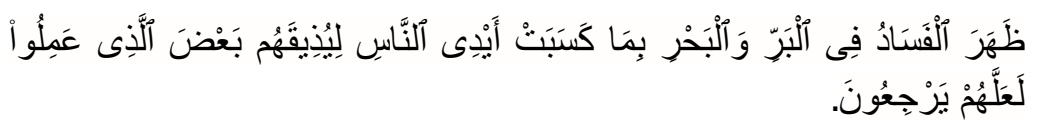

Artinya: Telah nampak kerusakan di darat dan di laut disebabkan karena perbuatan tangan manusia, supaya Allah merasakan kepada mereka sebahagian dari (akibat) perbuatan mereka, agar mereka kembali (ke jalan yang benar).

Berdasar dari firman Allah Swt diatas jika kita mau untuk memahami dan menghayati ayat tersebut tentu kita akan diberikan ketentraman hati dan kenyamanan pikir dalam menyikapi pandemi ini. Jika kita bisa menyadarinya maka akan

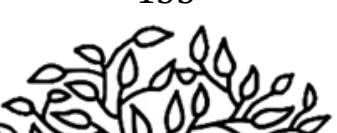




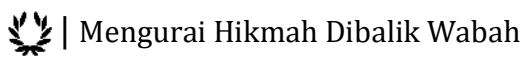

timbul dalam hati kita dalam pikiran kita bahwa betapa sifat Rahman-nya Allah Swt sungguh luar biasa besar, bagaimana tidak karena sejatinya jangankan dalam kebaikan, bahkan dalam keburukan yang dilakukan hamba-Nya sekalipun Allah Swt senantiasa berkehendak membuka tabir hikmah dalam setiap persoalan yang melanda, tidak terkecuali dalam wabah virus ini. Namun tidak semua orang dapat melakukan itu, hanya orangorang yang berimanlah yang senantiasa dalam keadaan apapun selalu memperoleh keuntungan, sabda Nabi Muhammad Saw yang diriwayatkan oleh Shuhaib bin Sinan :

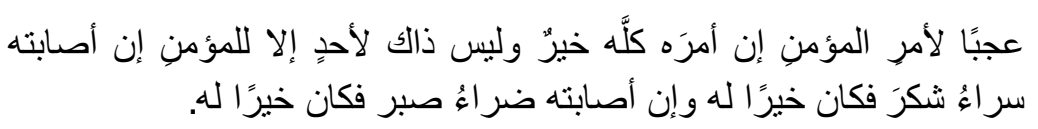

"Alangkah mengagumkan keadaan orang yang beriman, karena semua keadaannya (membawa) kebaikan (untuk dirinya), dan ini hanya ada pada seorang mukmin; jika dia mendapatkan kesenangan dia akan bersyukur, maka itu adalah kebaikan baginya, dan jika dia ditimpa kesusahan dia akan bersabar, maka itu adalah kebaikan baginya".

Secara umum hikmah dibalik wabah ini mengutip apa yang disampaikan oleh Nadirsyah Hosen :

Hikmah adanya wabah ini (Korona) luar biasa, Dari sisi ekosistem lingkungan dan alam, langit kembali menjadi biru, aliran sungai kembali jernih karena berkurangnya polusi udara dan sampah limbah akibat pabrik-pabrik berhenti beroperasi. "Pantai menjadi bersih dari sampah plastik. Ikan berenang gembira karena tak lagi diganggu kapal pesiar mewah. Burung terdengar bersahutan karena jalan raya tak lagi brisik dengan suara knalpot dan klakson.

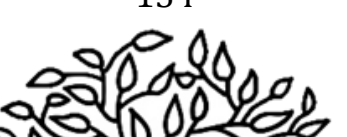


Keluarga yang selama ini tak pernah lagi duduk makan bersama dan saat bertemu biasanya hanya uang dan kerja yang dibahas, kini lebih banyak berkumpul di rumah beribadah dan beraktivitas bersama keluarga,"

Jika ada sementara pihak yang protes kenapa masjid ditutup dan kemudian muncul teori-teori konspirasi, sebenarnya mereka lupa bahwa pusat perjudian di Las Vegas Amerika dan Singapura juga tutup. Semua bar dan club di New York, Paris, dan London tutup. Tempat prostitusi di Jerman Belanda dan Rusia juga tutup. Semua kemaksiatan berhenti seketika akibat Corona. "Bukan karena takbir atau pentungan."

Sejatinya apapun yang terjadi adalah atas dan karena kehendak serta kekuasaan Allah, dan tentunya apa pun yang Tuhan berikan kepada kita tentu selalu saja mengandung hikmah (kebaikan) didalamnya. Tentu penulis tidak akan bisa menyebutkan satu per satu hikmah apa saja yang ada dibalik wabah ini, misal dalam bidang Pendidikan hikmah adanya wabah ini antara lain :

\section{Semua orang tua kembali menjadi guru yang sebenarnya} bagi anak-anaknya. Kebijakan institusi pendidikan yang melaksanakan belajar dari rumah dalam kegiatan belajar mengajarnya memiliki manfaat dan hikmah yang besar bagi guru, orang tua siswa dan siswa.

Bagi guru sendiri kesempatan ini bisa dijadikan evaluasi secara mandiri tentang bagaimana proses dan hasil yang sudah dicapai selama masa belajar normal (di sekolah dulu), dan juga guru harus memastikan mempersiapkan materi dengan sebaik-baiknya karena tentu belajar jarak jauh ada kendala-kendalanya.

Bagi orang tua hikmah belajar dirumah ini harusnya menyadarkan para orang tua bahwa kewajiban memberikan pendidikan kepada anak-anaknya bukan hanya sebatas

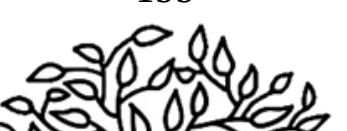




\section{*ै| Mengurai Hikmah Dibalik Wabah}

menyekolahkan, menguliahkan anaknya di institusi pendidikan namun juga harus berperan aktif dan terlibat dalam proses belajar terutama ketika dirumah. Selain itu orang tua juga memiliki kesempatan untuk lebih banyak berkumpul bersama anak-anaknya. Untuk orang tua yang berkerja penuh waktu dan rutinitas padat bercengkrama dengan anak-anak bisa saja menjadi barang langka yang sulit didapat.

\section{Ahli, pemangku kebijakan dan pelaksana Pendidikan} semakin progresif. Wabah korona mau tidak mau membuat elemen pendidikan mesti merombak total kebiasaan pembelajarannya. Ini berlaku untuk semuanya tanpa terkecuali harus mau mengikuti perubahan model pembelajaran sebelumnya berbasis offline (luar jaringan) sekarang menjadi online (dalam jaringan). Hikmah minimalnya semua pelaku pendidikan mulai dari tingkat dasar sampai perguruan tinggi mulai meletakan fungsi kecanggihan teknologi sesuai dengan porsinya, tidak melulu teknologi hanya sebatas dalam ranah hiburan dan sosial media seperti pada umumnya. Bahkan orang tua yang sebelumnya tidak tahu apa-apa tentang google classroom, google form, zoom dan lain sebagainya kini mereka mulai mengenal bahkan bisa mengaplikasikannya.

Wabah ini dengan segala kenegatifannya tetap menjadi ketentuan Allah yang terlaksana dengan pertimbanganpertimbangan hak ketuhanan Allah. Boleh saja kita marah pada, tidak terima, merasa payah dan lain sebagainya karena sejatinya sifat-sifat itu sudah biasa kita lakukan bahkan jauh sebelum adanya wabah. Namun alangkah lebih baiknya sebagai insan yang beriman kita mesti lebih bersabar dan menyadari bahwa ini ketentuan Allah yang mesti ikhlas kita terima. Sebab dengan sabar itulah kita bisa mengambil hikmah atas adanya wabah.

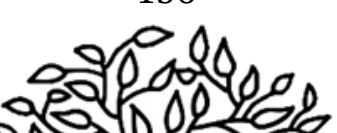


Berjamaah bersama keluarga dirumah, menjadi imam salat Tarawih bahkan salat idul fitri dirumah bukan hal yang bisa kita lakukan setiap tahunnya, kini semua orang memiliki kesempatan menjadi imam salat, kedudukan sakral bagi sebagaian golongan orang bukan ?, selain itu kita memiliki waktu lebih untuk kembali dirumah, melakukan hal-hal positif, mewujudkan konsep baity jannaty dalam konteks penataan suasana rumah tangga dan keluarga, menahan rindu kepada sanak saudara yang jauh disana, karena sebab rindu kita pun lupa dengan laku salahnya.

Terakhir penulis sampaikan bahwa hikmah terbesar dibalik wabah ini adalah ketika keimanan dan ketakwaan kita kepada Allah semakin meningkat setelah ini, laku hidup kita terus diperbaiki baik jasmani maupun ruhani dan kesalehan kita pun semakin tinggi baik secara ritual maupun sosial.

Fashobrun Jamil, Wallahu al mustanu ala ma tashifun 
| Mengurai Hikmah Dibalik Wabah 


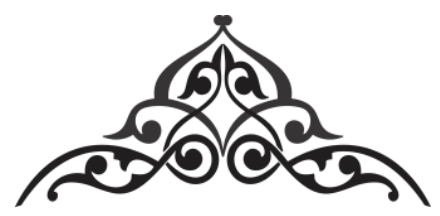

\title{
REDUKSI MISKONSEPSI KEIMANAN DI MASA PANDEMI COVID 19
}

\author{
Dr. Kurroti A'yun, S.T., M.Si. ${ }^{1}$ \\ STIT-UW Jombang
}

\begin{abstract}
"Menghadapi Covid-19 ini yang menjadi fokus untuk dilakukan seharusnya adalah dakwah bahwa wabah ini memang datang untuk menguji orang yang bertakwa dan sebagai azab bagi yang tidak bertakwa"
\end{abstract}

$\mathrm{M}$ anusia hidup di dunia ini sesungguhnya untuk apa? Pertanyaan ini merupakan petanyaan yang sangat lazim akan muncul dalam sanubari kita. Jawabannya sudah ada dalam kitab yang diturunkanNya sekitar 1, 4 abad tahun yang lalu melalui utusanNya, Muhammad SAW, berupa kitab suci al Quran yang diturunkan secara bertahap selama 22 tahun 2 bulan 22 hari. Tidak lain dan tidak bukan, jawaban atas pertanyaan pengantar di atas ada dalam firmanNya Q.S adz Dzariyat ayat 56, yang berbunyi:

1 Kurroti A'yun lahir di Surabaya, 20 April 1980, penulis merupakan Waket (Wakil Ketua) 3 sekaligus Dosen STIT-UW Jombang yang dalam bidang Pendidikan terutama dalam hal Reduksi Miskonsepsi secara Andargogik, penulis menyelesaikan gelar Sarjana di ITS (2004), kemudian mengabdi sebagai pendidik dan mendapatkan beasiswa dari Kemenag RI untuk menyelesaikan studi di ITS dengan gelar master sains (2009), gelar terakhir yaitu Doktor dalam Bidang Pendidikan diselesaikan dengan beasiswa dari LPDP yang diselenggaranan oleh Kemenkeu RI di Universitas Negeri Surabaya (2018). Selain itu, penulis juga bertugas sehari-hari untuk mendidik santri di PPUW Jombang dalam hal iman dan amal sholeh bersama Pembina PPUW Jombang. 


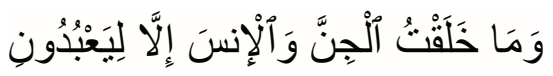

Artinya: Dan aku tidak menciptakan jin dan manusia melainkan supaya mereka mengabdi kepada-Ku.

Berdasarkan ayat tersebut, berarti kita sebagai manusia benar-benar diciptakan untuk mengabdi padaNya atau menjadi hambaNya, yaitu menjalankan perintahNya dan sesuai aturanNya. Namun, seiring dengan waktu hidup di dunia, terjadi perubahan jaman dan manusia lupa akan hakikat penciptaanNya, sehingga golongan manusia tak lagi satu (mengabdi padaNya). Sehingga muncul kejadian melanggar perintahNya, tidak taat pada aturanNya, di antaranya: 1. Mabuk-mabukan dengan menyalahgunakan narkoba, pergaulan bebas yang akhirnya sampai harus ada tindakan komunitas peduli sosial untuk melakukan tidakan preventif, represif dan kuratif (Putranto dan Suyatmi, 2015), 2. Pergaulan bebas yang akhirnya mengarah pada penyakit menular seksual mematikan dan obatnya belum benar-benar ada, seperti HIV-AIDS (Brody, 2010; Putranto dan Suyatmi, 2015; Zainuddin and Mahdy, 2016; Oktriyanto and Alfiasari, 2019), 3. Merusak ciptaanNya, yang salah satunya adalah merusak alam melalui membuang sampah sembarangan sehingga menyebabkan bencana alam, sampai diperlukan sosialisasi tindakan preventif, represif, dan kuratifnya (Wibisono dan Dewi, 2014; Ferdryansyah, Pancasilawan, dan Ishartono, 2018), dll. Sebab kesalahan manusia dalam menjalani hidupnya di dunia tidak disesuaikan dengan aturanNya, maka muncullah berbagai wabah mematikan sebagai adzab dariNya. Adzab Allah ini bukan tanpa sebab dan tanpa diingatkan dalam kitabNya. Allah jelas telah memperingatkan berkali-kali terkait apa yang harus dilakukan di dunia agar terhindar dan adzabNya disertai ancaman berupa adzabNya apabila melanggar perintahNya. Adapun contoh adzabNya di dunia yang ditimpakan kepada golongan manusia yang tidak mau menaati perintahNya ada dalam Q.S. al A'raf ayat 133, yang berbunyi sebagai berikut:

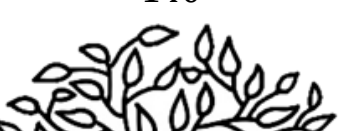




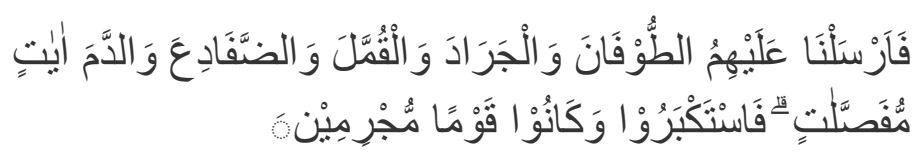

Artinya: "Maka Kami kirimkan kepada mereka (kaum Nabi Musa yang zalim) taufan, belalang, kutu, katak dan darah sebagai bukti yang jelas, tetapi mereka tetap menyombongkan diri dan mereka adalah kaum yang berdosa."

Berdasarkan ayat di atas, menunjukkan bahwa azab Allah dapat terwujud selama masih hidup di dunia atau bukan hanya diterima manusia nanti di hari akhir. Adapun azab ini akan diterima oleh kaum yang berdosa, yaitu yang menyombongkan diri sebab tidak taat pada perintahNya, aturanNya. Di ayat selanjutnya, Allah menunjukkan kasih sayangNya di dunia pada manusia tersebut, namun manusia yang sombong tersebut tetap tidak mau taat pada aturanNya atau tepatnya mengingkari petunjukNya yang diwujudkan dengan perilaku tidak mengakui kekuasaanNya. Keterangan ini difirmankanNya pada ayat 135 yang bunyinya:

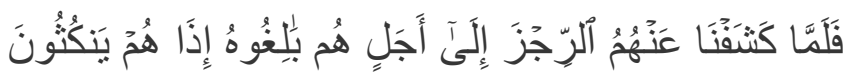

Artinya: "Maka setelah Kami hilangkan azab itu dari mereka hingga batas waktu yang mereka sampai kepadanya, tibatiba mereka mengingkarinya."

Azab yang Ia turunkan tidak hanya ketika kejadian yang dialami umat Nabi Musa yang zalim seperti dalam Q.S al A'raf di atas, namun juga dapat diturunkan pada kita saat ini apabila kita berbuat kezaliman (ketidak taatan pada aturanNya) yang serupa mereka. Seperti yang telah kita ketahui bahwa penyakit mematikan akibat ingkarnya manusia pada aturan hubungan antara laki-laki dan perempuan melalui kemaluannya yang tidak terjaga dengan proses pernikahan yang sah (di luar nikah)

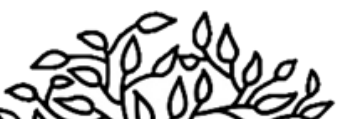




\section{" Reduksi Miskonsepsi Keimanan di Masa Pandemi Covid-19}

adalah HIV-AIDS (Adamczsyk and Hayes, 2012; Pereira and Carmo, 2013; Wagenlehner, Brockmeyer, Discher, Friese, and Wichelhaus, 2016). Ternyata tidak cukup disitu, saat ini, dimulai dari tahun 2019 silam muncul wabah baru yang dibawa oleh virus dengan jenis Covid-19 (Corona virus diseas tahun 2019) yang disebabkan ketidak taatan manusia dalam hal konsumsi makanan, yaitu memakan daging hewan yang diharamkanNya. Di mana, telah dijelaskan dalam al Quran tentang kriteria makanan yang diperbolehkan dikonsumsi untuk umat manusia di dunia, salah satunya tersaji dalam penggalan Q.S al Maidah ayat 3, yang berbunyi:

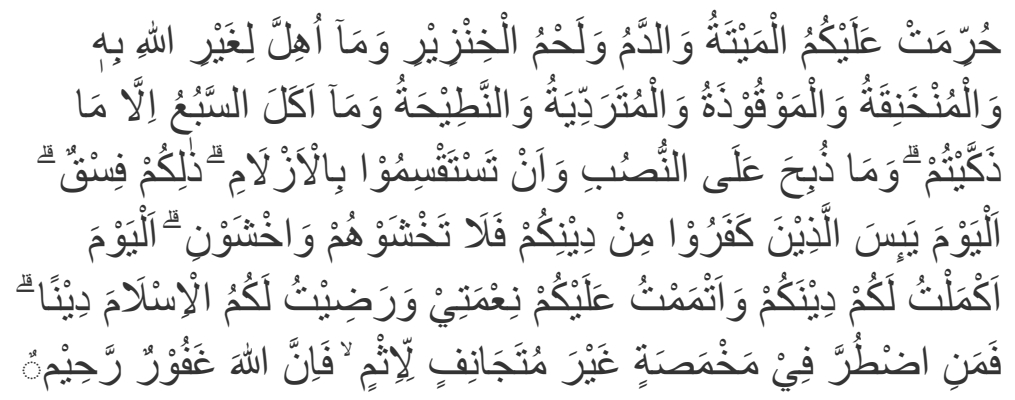

Artinya: "Diharamkan bagimu (memakan) bangkai, darah, daging babi, (daging hewan) yang disembelih atas nama selain Allah, yang tercekik, yang terpukul, yang jatuh, yang ditanduk, dan diterkam binatang buas, kecuali yang sempat kamu menyembelihnya, dan (diharamkan bagimu) yang disembelih untuk berhala. dan (diharamkan juga) mengundi nasib dengan anak panah, (mengundi nasib dengan anak panah itu) adalah kefasikan..."

Merujuk dari ayat di atas, dapat diketahui bahwa makanan yang diharamkan pada dasarnya hanya ada tiga, yaitu: bangkai (hewan darat yang matinya tidak disembelih), darah (darah hewan yang mengalir ke luar dari pembuluh darah; bahasa Jawanya dideh), daging babi (dikiyaskan dengan babi adalah

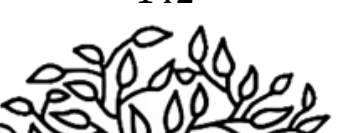


anjing, sebab ada dalam H.R Muslim no. 279). Selain itu, ayat ini ditambah keterangannya dalam sebuah hadis tentang hewan lain yang belum tersebut, yaitu dalam H.R. Muslim no. 1934 yang dibawa oleh Ibnu 'Abbas, Rasulullah Muahammad S.A.W. berkata:

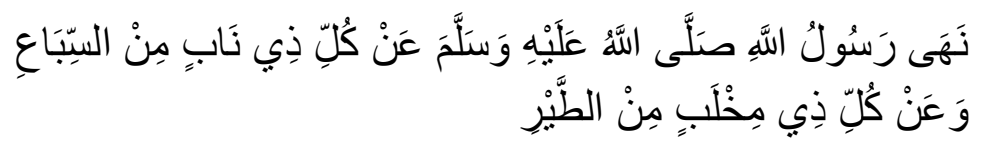

Artinya: "Rasulullah S.A.W. melarang memakan setiap binatang buas yang bertaring, dan setiap jenis burung yang mempunyai kuku untuk mencengkeram."

Namun, penjelasan firman Allah dan sabda Rasul di atas tidak dilaksanakan manusia, sehingga muncullah azab berupa Covid-19 yang ditularkan pertama kali melalui perantara hewan kelelawar di daerah padat penduduk, tepatnya di kawasan pasar daging hewan Wuhan di negara Cina (Huang et al, 2020; WHO, 2020). Memang di pasar Wuhan negara Cina tersebut terkenal sebagai pasar perdagangan berbagai macam hewan liar yang diharamkan, seperti tikus, kelelawar, trenggiling, dan lain-lain.

Wabah Covid-19 ini meskipun merupakan azab bagi orang yang tidak taat atau dengan kata lain tidak bertakwa padaNya, namun bukan berarti orang yang di dunianya bertakwa dan ditakdirkanNya terkena wabah ini berarti tidak bertakwa. Bagi orang yang bertakwa padaNya yang terkena wabah Covid19, ini berarti bukan mendapat azab, tapi mendapatkan ujian keimanan, di mana dalam Q.S. al Baqarah ayat 155 dijelaskan sebagai berikut:

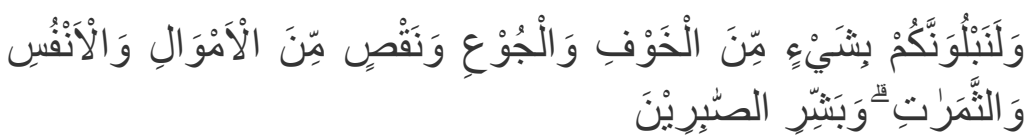

Artinya: "Dan sungguh akan Kami berikan cobaan kepadamu, dengan sedikit ketakutan, kelaparan, kekurangan harta,

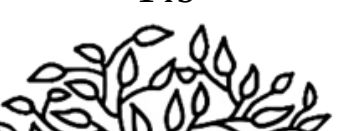


| Reduksi Miskonsepsi Keimanan di Masa Pandemi Covid-19

jiwa dan buah-buahan. dan berikanlah berita gembira kepada orang-orang yang sabar."

Q.S. al Baqarah ayat 155 tersebut mengingatkan kita bahwa selama hidup di dunia pasti akan diuji atau diberi cobaan hidup. Orang yang bertakwa pada Allah pasti bersabar ketika menghadapi ujian dariNya. Maka dari itu, bagi orang yang bertakwa, ketika mendapatkan ujian Covid-19 dalam tubuhnya, seyogyanya semakin mendekatkan diri padaNya. Pernyataan ini telah dibuktikan dalam penelitian yang telah dibukukan oleh Umarji and Elwan (2020), di mana dari hasil penelitiannya pada umat muslim, 58\% di antaranya semakin meningkat meskipun diiringi dengan ketakutan akan kematian. Adapun 48\% lainnya hanya merasa biasa saja (tidak meningkatkan kedekatannya pada Allah) dan hanya menambah ketakutan tanpa diiringi bentuk kedekatan pada Allah Yang Maha Kuasa. Kondisi ini merupakan kondisi yang diakibatkan dari miskonsepsi manusia dalam menghadapi permasalahan. Selain itu juga ada kondisi miskonsepsi lain, yaitu sibuk pada urusan ekonomi, kesehatan, dan pendidikan duniawi pendidikan umum; keresahan kekurangan materi ajar, dsb) (Gates, 2020; Pfefferbaum and Carol, 2020). Seharusnya, dalam menghadapi Covid-19 ini yang fokus dilakukan adalah dakwah bahwa wabah ini memang datang untuk menguji orang yang bertakwa dan sebagai azab bagi yang tidak bertakwa. Sehingga, bagi yang belum bertakwa karena berbagai alasan seperti belum memahami petunjukNya, dsb hendaknya segera membaca petunjukNya dalam al Qur'an dan dikuatkan dengan Hadis Rasul. Apabila diri sendiri belum mampu memahami secara lebih mendalam, ada baiknya untuk meminta fatwa pada ahli ilmu yang mengerti makna asli kandungan dalam ayat al Qur'an sekaligus Hadis RasulNya.

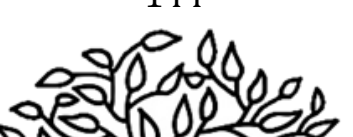




\section{DAFTAR PUSTAKA}

Adamczyk, Amy and Hayes, Brittany E. 2012. Religion and sexual behaviors: understanding the influence of islamic cultures and religious affiliation for explaining sex outside of marriage. American Sociological Association, 77(5): 723-746. Doi: $10.1177 / 0003122412458672$.

Brody, Stuart. 2010. The relative health benefits of different sexual activities. International Society for Sexual Medicine U Sex Med), 7:1336-1361. Doi: 10.1111/j.17436109.2009.01677.x.

Ferdryansyah, Muhammad.,

Pancasilawan, Ramadhan., Ishartono. 2018. Penanggulangan bencana di masyarakat desa studi di desa cipacing, desa cileles, dan desa cikeruh kecamatan jatinangor kabupaten sumedang. Social Work Journal. 8(1): 11-16. Doi: 10.24198/share.v8i1.15961.

Gates, Bill. 2020. Responding to covid-19 - a once-in-a-century pandemic? The New England Journal Medicine (NEJM), April 30: 1677-1679. Doi: 10.1056/NEJMp2003762. Diunduh tanggal 25 Juni 2020 dari https://www.nejm.org/doi/pdf/10.1056/NEJMp2003762?a rticleTools=true.

Huang, Chaolin. et al. 2020. Clinical features of patients infected with 2019 novel coronavirus in wuhan, china. Lancet. February $\quad$ 15; 395 (10223): $\quad$ 497506. Doi:10.1016/s0140-6736(20)30183-5.

Maron, Dina, F. 2020. 'Wet markets' likely launched the coronavirus: here's what you need to know. Washington D.C., U.S.: National Geographic. https://www.nationalgeographic.com/animals/2020/04/c oronavirus-linked-to-chinese-wet-markets/.

Oktriyanto and Alfiasari. 2019. Dating and premarital sexual inisiation on adolescence in Indonesia. Jurnal Kesehatan Masyarakat (KEMAS), December, 15(1): 98-108. Doi: https://doi.org/10.15294/ kemas.v15i1.17270. 
Pereira, Henrique and Carmo, Ana. 2014. Sexually transmitted diseases: knowledge and perceived prevalence of symptoms in university students. International STD Research \& Reviews, December 9: 2(1): 01-11. Article no. ISRR.2014.001.

Pfefferbaum, Betty and North, Carol S. 2020. Mental health and the covid-19 pandemic. The New England Journal Medicine (NEJM), April 13: 1-3. Doi: 10.1056/NEJMp2008017. Diunduh tanggal 5 Juni 2020 dari https://www.nejm.org/doi/pdf/10.1056/NEJMp2008017?a rticleTools=true.

Putranto, Dwi A. 2015. Kontrol sosial tim pencegahan, pemberantasan, penyalahgunaan dan peredaran gelap narkoba (P4GN) dan komunitas terhadap bahaya penyalahgunaan narkoba di kabupaten sukoharjo. Jurnal Sosiologi Dilema. Mei 29; 1(30): 1-16. ISSN: 0215/9635.

Umarji, Osman and Elwan, Hassan. 2020. Embracing uncertainty: how to feel emotionally stable in a pandemic. Irving, Texas, US: Yaqeen Institute for Islamic Research.

Wagenlehner Florian M.E., Brockmeyer, Norbert $H$. Discher, Thomas., Friese, Klaus., and Wichelhaus, Thomas A. 2016. The Presentation, Diagnosis, and Treatment of Sexually Transmitted Infections. Deutsches Ärzteblatt International, January 45(31): 113: 11-22.

Wibisono, Fajar A., Dewi, Piana. 2014. Sosialisasi bahaya membuang sampah sembarangan dan menentukan lokasi tpa di dusun deles desa jagonayan kecamatan ngablak. Jurnal Inovasi dan Kewirausahaan, Januari; 3(1): 21-27. ISSN: 2089-3086.

World Health Organization (WHO). 2020. Origin of sars-cov-2. Swiss, Jenewa: WHO. Diunduh tanggal 3 Juli 2020. WHO/2019-nCoV/FAQ/Virus_origin/2020.1.

Zainuddin, Ani A., Mahdy, Zaleha A. 2016. The islamic perspectives of gender-related issues in the management of patients with disorders of sex development. Springer link, Arch Sex Behav, April 21, 46:353-360. Doi: 10.1007/s10508016-0754-y.

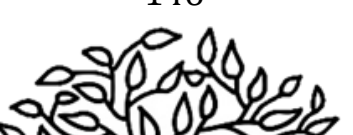




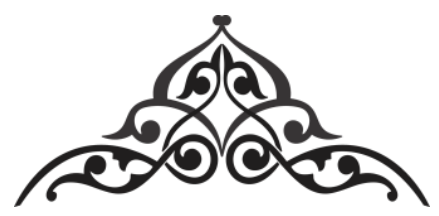

\title{
MANAJEMEN QOLBU DALAM MENINGKATKAN KINERJA DI TENGAH WABAH DUNIA
}

\author{
Supriadi, MM. ${ }^{2}$ \\ STAI Bumi Silampari Lubuklinggau Sumatera Selatan
}

"Qolbu yang kita inginkan adalah qolbu yang memiliki guratan dengan disertai energi positif dan mampu memberikan kehangatan yang dibutuhkan alam sekitar"

Cat ini kita dihadapkan dengan adanya wabah yang melanda
hampir di seluruh dunia. Apapun nama dan jenis wabah tersebut, terpenting kita harus menghadapinya bukan?. Setidaknya dalam sejarah, terdapat 11 wabah terbesar yang dikenal masyarakat, mulai dari wabah besar Marseille pada tahun 1720 sampai 1723, Epidemi demam kuning Philadelphia yang terjadi sekitar pada tahun 1793, adanya Pandemi Flu pada tahun 1889 sampai 1890, Epidemi Folio Amerika yang terjadi sekitar tahun 1916, Flu Spanyol sekitar tahun 1918 sampai 1920, Flu Asia sekitar tahun 1957 sampai 1958, Pandemi dan Epidemi AIDS yang terjadi mulai tahun 1981 hingga sekarang, Pandemi Flu termasuk Flu Babi yang terjadi mulai tahun 2009 hingga

2 Supriadi lahir di Palembang, 13 September 1980, penulis merupakan Dosen STAI Bumi Silampari Lubuklinggau Sumatera Selatan, penulis menyelesaikan gelar Strata-1 di Universitas Sriwijaya (2005), sedangkan gelar Magister Manajemen Sumber Daya Manusia diselesaikan di Universitas Bina Insan Lubuklinggau sebelumnya dikenal dengan Pasca Sarjana STIE Mura Lubuklinggau (2016). 


\section{" Manajemen Qolbu dalam Meningkatkan Kinerja di Tengah...}

sekarang, Epidemi Ebola Afrika Barat yang terjadi sekitar tahun 2014 sampai 2016, Pedemi Virus Zika yang terjadi sejak 2015 hingga sekarang, dan wabah saat ini yang muncul akhir 2019 sampai dengan sekarang adalah Virus Corona atau dikenal juga dengan COVID-19.

Dalam menghadapi wabah yang terjadi diperlukan manajemen diri dengan menggunakan Qolbu dalam meningkatkan kinerja kita. Manajemen merupakan ilmu dan seni dalam mengatur proses pemanfaatan sumber daya manusia disertai sumber-sumber lainnya secara efektif efisien dalam mencapai suatu tujuan tertentu (Hasibuan, 2014:2). Colquitt, LePine, dan Wesson (Wibowo 2017:2), memberikan pengertian kinerja sebagai nilai serangkaian perilaku pekerja dalam hal memberikan kontribusi, baik berbentuk positif maupun berbentuk negatif, untuk penyelesaian tujuan organisasi yang ingin dicapai. Sedangkan Qolbu yang dimaksud adalah hati yang bukan berbentuk fisik melainkan berbentuk 'nilai' atau sifat dalam diri sesorang.

Kekuatan Qolbu (hati) yang memungkinkan seseorang untuk bermoral, merasakan keindahan, kelezatan iman, dan kehadiran Pencipta. Dari kekuatan ini muncul intuisi dan indra keenam. Pengembangan potensi kekuatan hati (qolbu) melalui pendidikan yang tepat, dapat mengarahkan seseorang untuk memiliki iman dan kesalehan sejati sebagai cerminan hati yang sehat dan diberkati oleh Allah SWT (Alpiyanto, dll; 2013: 43).

Toto Tasmara (2001: 45-46) menyatakan bahwa Qolbu adalah hati nurani yang menerima banyak cahaya kebenaran ilahi. Seperti sejak di alam roh, kita telah menyaksikan kebenaran, sebagaimana dalam firman Allah Subhanallahta'ala dalam Al-Qur'an Al-A'raaf, surah ke tujuh ayat ke 172 yang berbunyi "Dan (ingat) ketika Robbmu tampil dari Bani Adam, dari kendali mereka, dari benih mereka, dan membuat mereka bersaksi tentang diri mereka sendiri, (mengatakan): Apakah Aku

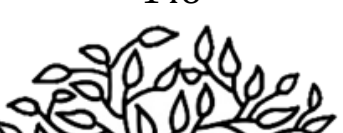


bukan Robb-mu? Mereka berkata: Ya! Sesungguhnya. Kami bersaksi. (Itu) supaya kamu tidak mengatakan pada Hari Kebangkitan: Lihatlah! kami tidak menyadarinya". Memahami Qolbu (bentuk masdar) dari Qolaba berarti mengubah, bergantiganti, tidak konsisten, berubah . Pada dasarnya, qolbu adalah tempat dalam kendaraan jiwa manusia yang merupakan titik sentral atau awal dari semua permulaan yang menggerakkan tindakan manusia yang cenderung baik dan buruk. Qolbu juga merupakan hamparan yang menerima nurani yang berasal dari roh dan sering disebut sebagai nurani (yang ringan) yang menerangi atau memberikan arahan kepada manusia untuk bertindak dan berperilaku berdasarkan keyakinan atau prinsip.

Manajemen Qolbu tergantung dari persepsi manajemen yang kita gunakan dalam keseharian kita masing-masing. Menurut Sumarkan dan Tutik (2008), kata dasar qolaba dalam Al-Qurr'an adalah 168. 36 kata adalah kata kerja dan 132 adalah kata benda.

Jika kita dapat memanajemen Qolbu kita itu sama halnya kita melakukan diplomasi atau berkomunikasi dan berdialog dengan qolbu, maka pada dasarnya kita melakukan dialog dengan alam semesta yang mengarah pada Pencipta alam semesta. Tidak akan ada lagi perdebatan tentang Islam, karena pada kenyataannya Islam tidak diperdebatkan tetapi dilakukan dan dijalankan dalam kehidupan sehari-hari mulai dari ketika kita bangun untuk kembali tidur.

Mari kita lihat seperti yang disebutkan dalam QS. AlAnkabuut, surah 29 ayat 69, Allah SWT berkata "dan mereka yang berusaha untuk mencari kesenangan kita. kami akan menunjukkan jalan-jalan mereka kepada mereka. Dan sesungguhnya Allah beserta orang-orang yang berbuat baik". Melakukan tindakan kebaikan adalah tindakan qolbu dan tentunya akan memengaruhi semua rangkaian kehidupan apalagi diplomasi dalam Islam. Karena sebenarnya diplomasi

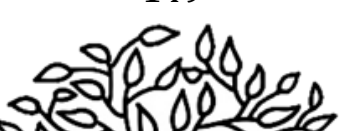




\section{" | Manajemen Qolbu dalam Meningkatkan Kinerja di Tengah...}

memerlukan tindakan, dan tindakan hanya akan ada jika telah dipindahkan oleh Qolbu dengan izin Allah SWT. Allah SWT berkata, "Dan katakan kamu bekerja maka Allah akan melihat pekerjaanmu serta para rasul dan orang-orang berimannya dan kamu akan dikembalikan kepada Allah yang mengetahui yang gaib dan yang nyata dan kemudian memberi tahu kamu apa yang telah kamu lakukan" (QS At-Taubah, surah 9 ayat 105). Yakinlah di QS. Ar-Rahman surah puluh lima ayat 60., Allah SWT mengatakan, "Tidak ada balasan untuk kebaikan selain kebaikan juga". Diplomasi dengan Qolbu kita sendiri, kemudian diplomasi di luar diri kita, terutama dalam memperkuat diplomasi Islam untuk orang-orang di seluruh dunia. Maka akan diperoleh apa yang kita sebut dengan rahmatan lil alaamin.

Pada akhirnya kita semua akan diminta pertanggungjawaban di alam setelah kehidupan ini. Artinya apapun yang terjadi dalam hidup kita, apapun itu termasuk dalam menghadapi berbagai wabah yang sudah terjadi, sedang terjadi, ataupun yang akan terjadi haruslah kita jalani dengan melakukan manajemen diri yang bermula dengan manajemen Qolbu kita.

Qolbu hanya bisa digunakan perannya apabila kita bisa menjaganya dari hal-hal yang akan merusak Qolbu itu sendiri. Hal-hal yang dapat merusak Qolbu antara lain;

1. Menginkari adanya Pencipta qolbu, yaitu Rabb yang Esa. Seolah kita sendiri yang bisa melakukan segala perbuatan tanpa adanya campur tangan dan izin Pemilik dan Pencipta Qolbu;

2. Berbuat kerusakan pada jasad yang menaungi Qolbu dengan cara-cara tertentu misalnya dengan memakan yang diharamkan, meminum yang diharamkan dan lain sebagainya

3. Menganggap biasa perbuatan yang tercela sehingga menjadi kebiasaan dan terbiasa (habbit), padahal sesungguhnya

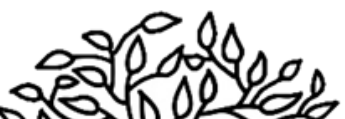


perbuatan yang tercela itu bisa merusak Qolbu. Perbuatan tersebut masuk didalamnya perbuatan fitnah, janji palsu, bersumpah tujuh keturunan seolah-olah menegaskan dirinya benar dan lain sebagainya.

Adapun Hal-hal yang dapat menjadikan Qolbu sebagai alat kita dalam manajemen sehingga meningkatkan kinerja antara lain;

1. Senantiasa memakan makanan dan minum minuman yang jelas asal usulnya, jelas kehalalan dan kebaikannya. Jelas sumber memperolehnya dan lain sebagainya;

2. Senantiasa menggantungkan semua harapan dan keinginan hanya kepada Rabb Pencipta alam semesta dengan cara mendekatkan diri kepada NYA, melaksanakan apa yang telah diperintahkanya dan menjauhi yang dilarang NYA.

3. Senantiasa Belajar tiada henti, berteman dan bersahabat dengan orang-orang yang berpikir positif dalam menjalani hidup dan kehidupan. Hal ini akan menjadikan salah satu kontrol/cermin kita dalam melangkah menghadapi persoalan-persoalan dalam hidup.

Sebagai penutup, Mari kita gunakan Qolbu kita, kita manage Qolbu kita dengan sebaik mungkin mulai dari merencanakan bagaimana kita menjalani hidup kita, bagaimana kita menyusun tahapan-tahapan kegiatan kita, bagaimana kita melaksanakan apa yang sudah kita siapkan dan akhirnya bagaimana kita melakukan evaluasi atas apa yang sudah kita lakukan untuk seterusnya kita jadikan acuan untuk melangkah lebih baik lagi. Meski secara fisik setiap manusia memiliki hati, dimana terdapat banyak guratan-guratan. Guratan-guratan tersebut ada yang lurus ada yang miring bahkan banyak pula yang bengkok dengan arah yang berlawanan serta bervariasi. Sumber guratan yang ada ini berasal dari aneka visual bergantung sudut pandang baik yang langsung terlihat maupun yang yang masih dalam bayangan, persepsi dan sudut pandang

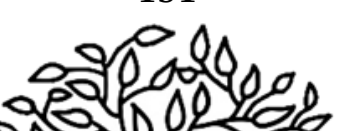


| Manajemen Qolbu dalam Meningkatkan Kinerja di Tengah...

juga dipengaruhi dari input pendengaran yang kita terima, input makanan yang kita makan serta aneka minuman yang kita minum, bahkan bertambah akibat sentuhan yang kita lakukan bukan pada tempat semestinya. Sehingga semakin banyak guratan pada hati berdampak dengan hasil Qolbu yang menjadi pengatur gerakan kehidupan kita, dimana semakin banyak guratan maka perlahan namun pasti Qolbu akan menjadi mengeras dan pada akhirnya membeku, tanpa adanya gerakan tanpa detak dan tanpa adanya aliran kehidupan. Sahabat, selamat beraktivitas dan mari senantiasa menggunakan Qolbu kita dengan manajemen terbaik, yang pada akhirnya meningkatkan kinerja kita dalam menghadapi semua kondisi dan keadaan meski dalam kondisi di tengah wabah yang melanda dunia. Qolbu yang kita inginkan adalah qolbu yang memiliki guratan dengan disertai energi positif dan mampu memberikan kehangatan yang dibutuhkan alam sekitar. Wallahu'alam bishawab.

\section{DAFTAR PUSTAKA}

Alpiyanto. Dkk. 2013, Aplikasi Pendidikan Karakter \& Metode Pembelajaran yang Mencerdaskan Berbasis Hati Nurani. Yogyakarta. Ar-Ruzz Media.

Hasibuan, Malayu. 2014. Manajemen: Dasar, Pengertian dan Masalah. Jakarta: Bumi Aksara.

Sumarkan, Titik Triwulan Tutik. 2008. Misteri Hati dalam diri Manusia Perspektif Al-Qur'an. Jakarta. Lintas Pustaka Publisher.

Supriadi., Alisyahbana, Takdir. 2020. Islamic Diplomacy by

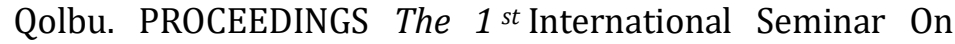
Islamic Diplomacy STAI Bumi Silampari Lubuklinggau Vol 1. Lubuklinggau. STAI Bumi Silampari.

Tasmara, Toto, Haji. 2001. Transcendental Intelligence. Jakarta.

Gema Insani Press.

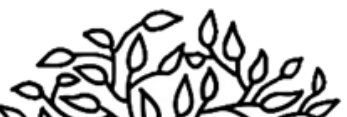


Supriadi, MM. | |

Wibowo. 2017. Manajemen Kinerja. Depok: PT RajaGrafindo Persada 
| Manajemen Qolbu dalam Meningkatkan Kinerja di Tengah... 


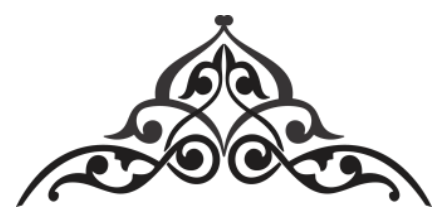

\title{
SYUKUR DALAM MASA PANDEMI COVID-19
}

\section{Aris Priyanto, M.Ag² \\ IAIN Pekalongan}

\author{
"Melalui bersyukur, seseorang akan memperoleh \\ kesempurnaan, kelestarian, dan pertambahan nikmat"
}

\section{$\mathrm{M}$} anusia senantiasa berusaha untuk memenuhi kebutuhannya agar segala keinginannya bisa tercapai dan merasakan kebahagiaan. Atas dasar tersebut, manusia berfikir bahwa kebahagiaan bisa tercapai jika keinginannya juga tercapai. Namun, jika keinginan tersebut tidak tercapai maka manusia akan merasa bahwa dirinya celaka dan susah selamanya. Padahal beribu-ribu keinginannya sudah tercapai, namun ia selalu mengeluh dan merasa susah.

Melihat kondisi manusia yang sedemikian rupanya, tentu manusia tidak akan pernah merasa puas terhadap apa yang sudah ia dapatkan. Bahkan berbagai keinginan yang berlebihan tersebut seringkali membuat diri mereka mengalami naik turun dalam sisi keimanan kepada Allah SWT. Rasa berlebihan terhadap hal duniawi mampu diatasi dengan adanya pengendalian diri dari hawa nafsu dan juga rasa syukur kepada Allah SWT.

2 Aris Priyanto lahir di Pekalongan, 06 April 1988, penulis ${ }^{1}$ merupakan Dosen IAIN Pekalongan dalam bidang Ilmu Tasawuf, penulis menyelesaikan gelar Sarjana Ilmu Tasawuf dan Psikoterapi di IAIN Pekalongan (2017), sedangkan gelar Magister Ilmu Agama Islam di UIN Walisongo Semarang (2019). 
Pengendalian diri dari hawa nafsu dengan rasa syukur pada masa pandemi covid-19 ini sangat penting sekali. Karena, secara tidak langsung manusia diajak untuk mensyukuri atas segala nikmat yang telah diberikan oleh Allah sebelum adanya covid-19 ini. Mereka menyadari atau tidak, bahwa selama ini mereka telah lupa atas nikmat yang telah diberikan oleh Allah SWT, baik dalam berupa nikmat sehat, nikmat riski lancar, nikmat bisa berkumpul dengan siapapun dan tentunya nikmat untuk berinteraksi tanpa ada batasan tertentu. Sehingga, dengan adanya protokol kesehatan pencegahan covid-19 untuk tetap di rumah (stay at home) sebagai dampak adanya pandemi covid-19 ini, sudah seharusnya mereka bersyukur. Mereka yang selama ini jarang berinteraksi dengan keluarga, kurang waktu istirahat di rumah, dan terlalu banyak di luar rumah, saat ini semua itu bisa mereka lakukan dan mereka benar-benar merasakan pentingnya bersyukur atas semua itu.

Menurut Al Ghozali, syukur merupakan salah satu maqam yang paling tinggi setelah sabar dan khauf (takut kepada Allah) dan maqam-maqam lain yang digunakan untuk mendekatkan diri kepada Allah. Syukur juga termasuk sebuah sikap ridla terhadap segala sesuatu yang telah diberikan oleh Allah SWT kepada manusia, baik sesuatu itu berupa hal yang baik atau berupa hal yang buruk menurut pandangan manusia. Syukur bisa dilakukan dengan hati, ucapan, dan perbuatan atau perilaku. Kondisi seseorang yang bersyukur atau tidak bisa terlihat dalam perilaku keseharian manusia yang merupakan cerminan dari rasa syukur yang telah diterapkannya. Allah memerintahkan manusia untuk selalu bersyukur dalam segala hal dan jangan mengingkarinya. Sebagaimana firman Allah dalam surat Al Baqaroh ayat 152:

$$
\text { فَأْكُرُونِي أَذْكُرْكُمْ وَاشْكُرُو ا لِي وَلَا نَكْفُرُونِ }
$$

Artinya: "karena itu, ingatlah kamu kepada-Ku niscaya aku ingat (pula) kepadamu, dan bersyukurlah kepada-Ku, dan janganlah kamu mengingkari (nikmat)-Ku."

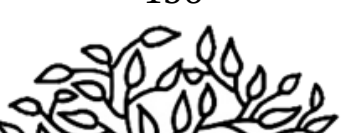


Ayat tersebut secara tegas memerintahkan kepada semua orang untuk selalu bersyukur pada Allah atas segala nikmat yang diberikan. Sehingga, rasa syukur apabila diterapkan dalam kondisi pandemi covid-19 ini sangat tepat sekali, sebab meskipun berbagai aktivitas kita saat ini sangat terbatas, namun secara tidak langsung Allah masih memberikan kita nikmat berupa nikmat sehat tidak terkena virus itu, nikmat tetap bisa beraktivitas meskipun dari rumah dan nikmat bisa banyak waktu bersama keluarga dan juga banyak istirahat di rumah.

Semua itu apabila kita menyikapinya dengan rasa syukur tentu berbeda ketika kita menyikapinya dengan rasa kufur nikmat. Bisa dibayangkan, bagaimana mereka yang terkena virus corona di isolasi, tidak bisa bertemu dengan keluarga, bahkan selalu terbayang-bayang dengan kematian dan kecemasan akan tidak bisa sembuh karena terkena virus itu. Kondisi tersebut apabila tidak didasari dengan ilmu, keadaan, dan perbuatan, tentu akan berbeda akhirnya. Al Ghozali menguraikan bahwa syukur itu tersusun dari tiga hal, yaitu ilmu, keadaan, dan perbuatan. Ilmunya syukur adalah menyadari bahwa kenikmatan yang diterimanya itu semata-mata dari Dzat Yang Maha Pemberi Kenikmatan yaitu Allah. Keadaan syukur adalah menyatakan kegembiraan yang timbul sebab memperoleh kenikmatan tadi, sedangkan amalannya syukur adalah menunaikan sesuatu yang menjadi tujuan serta yang dicintai oleh dzat yang memberi kenikmatan.

Sebagai umat manusia yang bertuhan dan beragama, tentunya kita harus bisa memahami dan menyadari bahwa musibah dalam bentuk pandemi covid-19 itu merupakan kehendak dan kekuasaan Allah. Apabila mereka bisa seperti itu, maka mereka juga harus mampu menyadari bahwa obat tersebut adalah dalam bentuk mendekatkan diri kepada Allah SWT. Mendekatkan diri kepada Allah melalui syukur merupakan salah satu obat untuk mengatasi pandemi covid-19 ini. Bisa jadi,

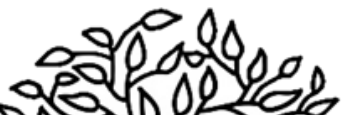


kemunculan pandemi covid-19 ini karena mereka mengalami kekeringan atau kehausan atas spiritual diri mereka. Sehingga mereka harus bersyukur kepada Allah yang telah memberikan nikmat yang begitu besar kepada mereka. Sebagaimana Allah berfirman dalam QS. Ibrahim:7.

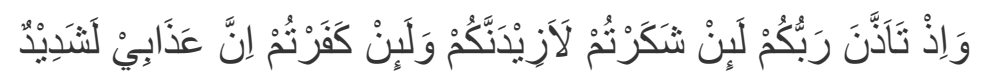

"Dan (ingatlah juga), tatkala Tuhanmu memaklumkan; "Sesungguhnya jika kamu bersyukur, pasti Kami akan menambah (nikmat) kepadamu, dan jika kamu mengingkari (nikmat-Ku), Maka Sesungguhnya azab-Ku sangat pedih".

Muhammad Ibn Salim Ibn Sa'id dalam kitab Is'ad ar-Rafiq, menjelaskan kandungan ayat tersebut bahwa ketika seseorang itu sudah bersyukur, maka Allah akan menambahkan baginya pertolongan dan nikmatnya. Sementara apabila seseorang tersebut mengkufuri nikmat Allah, maka baginya siksa yang amat pedih di akhirat nanti. Syukur mampu membuka rahasia penciptaan entitas-entitas yang tersembunyi, rahasia kenikmatan yang berlaku di semua pembentukan. Sehingga seseorang senantiasa mensyukuri sebagai nikmat, bersabar mengahadapi musibah, menjalankan perintah dan menjauhi larangan.

Menerapkan syukur dalam masa pandemi covid 19, tentunya merupakan salah satu bentuk ikhtiar dalam upaya penyelamatan diri, keluarga, saudara, kerabat dan semua orang di dunia ini. Peranan syukur dalam masa pandemi covid-19 mampu menyelamatkan manusia dari terpapar virus corona (covid-19). Sebab apabila kita tidak mensyukuri atas adanya pandemi covid-19 ini, tentunya kita akan menentang serangkain protokol pencegahan penularan covid-19.

Syukur yang dilakukan secara teratur mampu meningkatkan kebahagiaan, kesehatan, mood, hingga hubungan

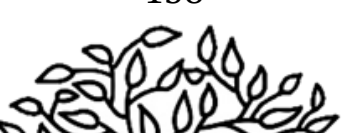


dengan pasangan. Bahkan syukur juga mampu membuat orang merasa lebih bahagia dan tidak mudah depresi. Rasa syukur juga bisa membawa efek yang luar biasa dari segi fisik, psikologi dan sosial. Rasa bersyukur kepada Allah manfaatnya akan kembali kepada mereka sendiri, bukan kepada Allah sebagai pemberi nikmat. Karena kebesaran dan kekuasaan Allah tidak bertambah dengan lantaran rasa syukur manusia kepada-Nya. Begitu juga sebaliknya, perilaku kufur nikmat yang dilakukan oleh manusia juga tidak merugikan Allah. Sebab kebesaran dan kekuasaan Allah tidak akan berkurang lantaran ingkarnya manusia terhadap nikmat yang telah Ia berikan. Sebagaimana penegasan al-Qur'an melalui lisan Nabi Sulaiman:

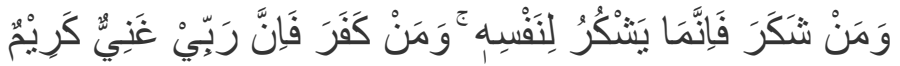

"Barangsiapa yang bersyukur, Maka Sesungguhnya Dia bersyukur untuk (kebaikan) dirinya sendiri dan Barangsiapa yang ingkar, Maka Sesungguhnya Tuhanku Maha Kaya lagi Maha Mulia"(an-Naml 27:40).

Melalui bersyukur, seseorang akan memperoleh kesempurnaan, kelestarian, dan pertambahan nikmat. Dengan bersyukur, nikmat yang telah ada akan terjaga, sedangkan nikmat yang hilang akan kembali lagi. Rasa syukur tidak selalu ditujukan kepada Allah, namun syukur bisa ditujukan kepada sesama manusia. Ungkapan rasa syukur dalam sesama manusia biasanya diungkapkan dengan ucapan terimakasih. Sehingga rasa enggan untuk bersyukur kepada sesama manusia secara tidak langsung berarti ia enggan untuk bersyukur kepada Allah. Rasulullah SAW bersabda:

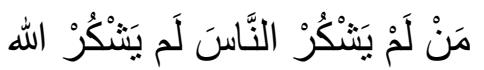

"Barangsiapa tidak bersyukur kepada manusia berarti ia tidak bersyukur kepada Allah" (HR. Ahmad dan AtTirmidzi).

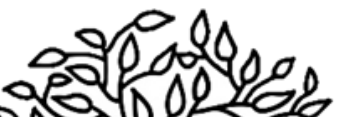


Berbagai himbauan dan protokol kesehatan terkait pencegahan dan penularan covid-19 yang dilakukan oleh pemerintah dan seluruh relawan satgas covid-19 merupakan sebuah upaya mereka agar kita semua senantiasa tidak tertular dari virus itu. Sebagian dari mereka juga yang secara sukarela memberikan sebagian hartanya untuk membantu pemerintah untuk mencegah penularan virus tersebut sebagai bentuk rasa kemanusiaan. Sementara kita yang hanya diminta untuk stay at home saja, seringkali kita mengabaikan himbauan pemerintah terkait hal itu. Sehingga bersyukur atas pandemi covid-19 merupakan sebuah langkah yang tepat saat ini.

\section{DAFTAR PUSTAKA}

Al Ghazali, tt., Ihya' 'Ulum ad-Din, Surabaya: Al Hidayah.

Al Qasimi, , tt, Mauidhotul Mu'minin min ihya' Ulum Addin, Surabaya: Daar Al Kutub Al Islamiyah.

As-Suyuti, t.t, al Jami' as-Shahir min Ahadis al-Basyir an-Nazir, (Beirut: Dar al-Fikr)

Mahfud, Choirul, 2014, The Power of Syukur, Tafsir Kontekstual Konsep Syukur dalam al Qur'an, Jurnal Episteme, Vol. 9.

Salim Ibn Sa'id, Muhammad Ibn, tt., Is'ad ar-Rafiq, Juz 2 I, Kediri: Petuk.

Suryomentaram, Gangsang, 1989, Kawruh Jiwa: Weajanganipun Ki Ageng Suryomentaram, jilid 1, Jakarta: Hajimasagung. 


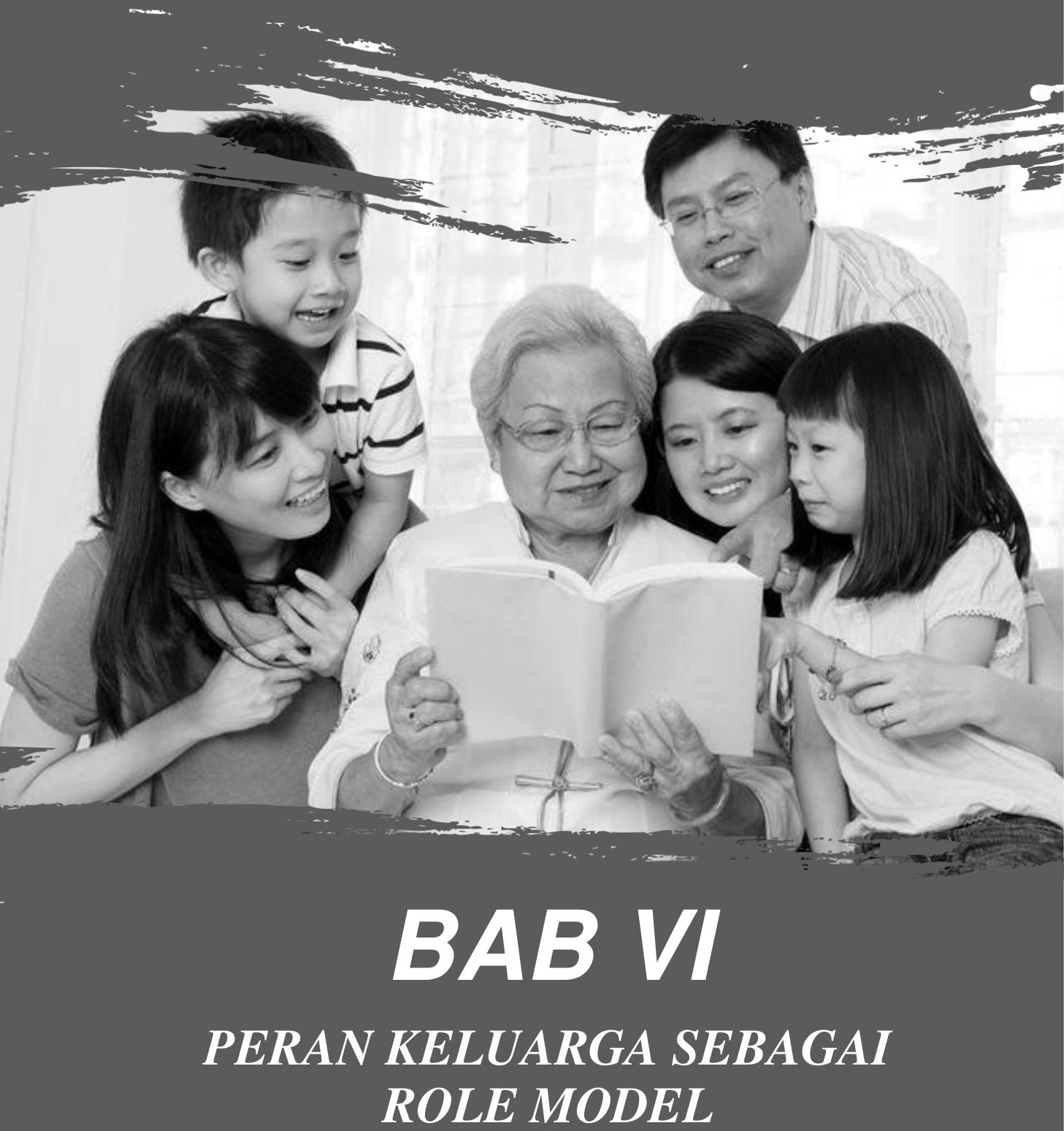


162 


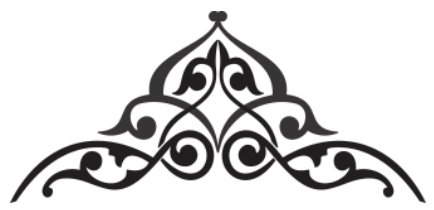

\title{
DAMPAK MASA PANDEMI COVID19 TERHADAP FUNGSI KELUARGA SEBAGAI LEMBAGA PENDIDIKAN INFORMAL
}

\section{Azizah Husin² \\ FKIP Unsri}

"Pandemi Covid-19 telah ikut mengembalikan hakekat keluarga sebagai wadah pendidikan dasar dengan

kasih sayang dan berbasis kasih sayang dan kebahagiaan. Keluarga bisa kreatif merencanakan kegiatan kebersamaan dalam keluarga dengan leluasa, tanpa beban dikejar waktu untuk pergi keluar rumah"

\begin{abstract}
A ktivitas sehari hari sebelum masa pendemi covid, orangtua sibuk mencari nafkah untuk keluarga. Anak sibuk sekolah / kuliah, kursus, dan kegiatan lainnya diluar rumah. Sebagian besar orangtua menyerahkan pendidikan anak baik formal maupun non formal pada lembaga/ pihak lain dan diluar rumah, ada juga yang mendatangkan guru/ instruktur ke rumah. Perjalanan untuk kerja, sekolah/ kuliah, dan aktivitas lain cukup menyita waktu dan juga melelahkan. Ketika terjadinya pandemic covid19, masyarakat diharuskan untuk diam dirumah demi keselamatan dan kesehatan bersama.. Pandemi covid19 memiliki dampak yang sangat luas dan mendasar bagi masyarakat dunia,
\end{abstract}

2 Azizah Husin lahir di Palembang.Saat ini penulis merupakan dosen FKIP Unsri prodi Pendidikan Luar Sekolah/ Pendidikan Madsyarakat. Penulis menyelesaikan pendidikan program Doktor di UNJ tahun 2011. 


\section{| Dampak Masa Pandemi Covid19 Terhadap Fungsi Keluarga...}

tidak terkecuali Indonesia bahkan merombak hampir semua aspek kehidupan, termasuk pola hidup. Wabah ini menyebar begitu mudah dan cepat sehingga pemerintah menetapkan peraturan yang harus dipatuhi masyarakat demi kesehatan dan keselamatan bersama. Ketetapan itu adalah untuk tinggal dirumah ( Stay at Home).

Dunia pendidikan terkena dampak yang sangat besar yakni pada lembaga pendidikan formal, non formal dan informal. Dampak ini meluas dan mendalam kesemua gerak kehidupan masyarakat. Peraturan diam dirumah berlaku untuk semua baik yang bekerja, belajar, dan kegiatan lain yang menyebabkan orang harus keluar rumah. Pemerintah menyediakan solusi dengan work from home, belajar, seminar, rapat, dan kegiatan lainnya secara daring. Hal ini mengindikasikan pelarangan tatap muka untuk menghindari penyebaran wabah covid19.

Adanya kebijakan stay at home dengan melakukan kerja, ibadah, dan belajar di rumah yang diambil oleh pemerintah, tujuannya dalam rangka memutus mata rantai penularan Covid19 ini. Dan mengharuskan anak-anak usia sekolah belajar di rumah, disadari atau tidak telah mengembalikan tugas dan tanggung jawab orang tua dalam melakukan pendidikan bagi anak-anaknya. Orang tua berperan sebagai pendidik yang mengajari anak-anaknya di rumah. Kondisi pandemi covid ini berlangsung tanpa batas waktu, sehingga masyarakat harus menyiapkan diri, mental, pikiran dengan membuat program agar tidak bosan dirumah dan melakukan kegiatan yang bermanfaat.

Menyadari atau tidak masyarakat dituntut untuk mengisi masa masa pandemic covid ini memanfaatkan dampak ini dengan maksimal. Orangtua membuat program pendidikan kepada anak meskipun tidak perlu rencana ini dinyatakan kepada anak. Semua implementasinya akan berjalan secara mengalir untuk diimplementasikan oleh anggota keluarga.

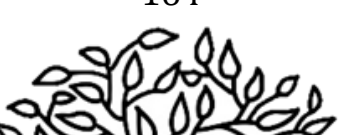


Peraturan berdiam dirumah tidak bisa dihindari. Rumah memiliki fungsi yang beragam. Rumah tempat kumpul keluarga,tempat berlindung, tempat istirahat, tempat berbagi kebahagian, kebersamaan dalam suka dan duka, tempat yang ibadah, tempat bersenang, tempat peletakan pendidikan dasar dan lain lain. Sebelumnya, fungsi rumah sebagai tempat pendidikan tidak maksimal, karena kesibukan orangtua dan anak serta habisnya waktu diluar rumah untuk menuju tempat kerja dan sekolah/ kuliah. Selain itu fungsi pendidikan dalam keluarga tidak maksimal dan tidak intensif karena banyak lembaga baik pendidikan formal maupun non formal melakukan fungsi pendidikan, bahkan anak anakmenghabiskan waktunya lebih lama diluar seperti sekolah,. Anak menghabiskan waktu selama lebih kurang 8 jam disekolah, belum ditambah lagi dengan waktu yang dihabiskan dijalan/ diperjalanan. Setelah itu, anggota keluarga disibukkan oleh jadwal bekerja, sekolah, bermasyarakat, mendapatkan keterampilan/ kursus, berorganisasi dll. Orangtua dan anak menghabiskan waktu hamper 2/3 di jalan dan diluar rumah. Kegiatan itu sudah rutin dan lazim didunia masa kini. Dengan kondisi pandemic ini, fungsi maksimal rumah sebagai lembaga pendidikan informal diingatkan kembali. Jadi orangtua dtuntut melaksanakan fungsi pendidikan dan pengajaran kepada anak Fungsi keluarga sebagai "rumah" bukan hanya sekedar menyediakan tempat tinggal saja, tapi juga membuat seluruh anggota keluarga merasa seperti memiliki "rumah" sebagai tempat perlindungan yang menawarkan rasa aman dan proteksi yang baik. Sebuah "rumah" di dalam keluarga akan memberikan dukungan emosional dan psikologis untuk semua anggota keluarga. Di samping itu, fungsi "rumah" dalam keluarga adalah memenuhi kebutuhan cinta bagi setiap anggota keluarga tersebut.

Dengan berkumpulnya semua anggota keluarga berada dirumah untuk waktu yang tidak diketahui kapan berakhir,

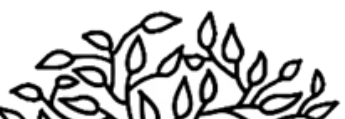




\section{1ै. Dampak Masa Pandemi Covid19 Terhadap Fungsi Keluarga...}

sudah pasti terjadi bingung dan bosan akan muncul. Sebagai orangtua maka mereka harus cepat tanggap memanfaatkan situasi ini dengan maksimal mendidik anak yang mungkin sebelumnya tidak terlaksana dengan baik karena peran itu disisi pihak/ lembaga lain. Maka orang tua menantang seorang ibu untuk menciptakan suasana pendidikan dan pembelajaran didilngkungan/ dalam keluarga. Ibu menjalankan perannya lebih utuh, begitupun bapak, dan juga anak dan anggota keluarga lainnya. Orang tua harus kreatif menciptakan suasana pendidikan dan pembelajaran dan kebahagiaan dalam rumah, agar tidak ada rasa kejenuhan dan tertekan atau stress dari anggota yang tidak siap dan tidak sabar dengan kondisi ini.

Pendidikan informal dalam keluarga terlaksana tanpa tekanan waktu, beban target dan sangat fleksibel. Ciri dan pendidikan informal adalah apasaja bisa jadi objek pendidikan jika dipandang dan dimanfaatkan. Waktu yang tersedia dalam keluarga banyak dan. Peristiwa pendidikan terjadi dengan begitu saja. Orang tua melakukan tugas pendidikan secara naluriah Tugas dan tanggungjawab orang tua dalam pendidikan anak melekat dengan fungsi keluarga itu sendiri. Hal ini juga didukung oleh pemahaman orangtua bahwa anak adalah amanah dari Yang Maha Kuasa, dimana orangtua kelak akan diminta pertanggungjawaban atas titipan tersebut. Kalau didunia orangtua mendidik anak tidak baik, maka merekalah juga yang akan menuai hasilnya, hal ini juga akan dituntut dihari kemudian apakah anak diberi pendidikan baik atau tidak baik. Atau juga anak diabaikan begitu saja.

Keluarga bisa kreatif merencanakan kegiatan kebersamaan dalam keluarga dengan leluasa, tanpa beban dikejar waktu untuk pergi keluar rumah. Manfaat adanya wabah covid19, the function of the family as an informal educational institution (Husin: 2019) bisa dimaksimalkan. Kejadian ini mengembalikan hakekat keluarga sebagai wadah pendidikan dasar dengan kasihsayang

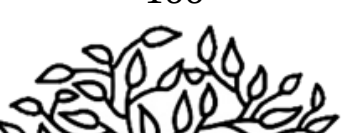


dan berbnasis kasihsayang dan kebahagiaan. Pendidikan dalam keluarga adalah sangat penting. Pendidikan keluarga sebagai dasar pertahanan untuk menghadapi gangguan negative dari luar rumah, pendidikan keluarga memberikan moral dasar untuk anak kuat, mandiri, bermoral, berakhlaq, sehat, jasmani dan rohani. Pendidikan keluarga memiliki kesempatan yang banyak dan panjang dimasa covid ini orangtua dapat merencanakan dan mengisi masa kebersamaan ini dengan sebaik baiknya.

Pendidikan keluarga sepanjang waktu (Pramudia: 2013) anak membutuhkan pendidikan, orangtua menanamkan unsur pengetahuan, nilai-nilai/ sikap, keterampilan, dan pembiasaan perilaku. Children are guided by positive habituation, honesty, responsibility, work ethic, religion, discipline, patience, tenacity, work skills, independence, environmental care and the values of character education which are also instilled in schools (Husin: 2020) lainnya. Pendidikan keterampilan membersihkan rumah, ketrampilan membantu pekerjaan rumah yang menjadikan anak menghargai pekerjaan apapun yang penting halal dan mendidik untuk bekerja dengan baik.agar anak tidak memililih milih dan menilai rendah keterampilan kerja yang berasal dari rumah. Karena kedepannya anak sangat dituntut untuk mandiri untuk tidak menggunakan jasa pihak lain itu adalah lebih baik. Dirumah semua itu dapat didapat. Pengabdian dan kesetiaan dan integritas. Anak diberi contoh teladan tentang cara/ praktek melakukan pekerjaan rumah, car acara beribadah, keterampilan.

Pendidikan informal (Sudjana: 2004) dalam keluarga dilaksanakan secara tidak sengaja, tidak terjadwal, cara memperoleh bahan/ materi pendidikan bisa bersifat kebetulan, objek/ materi bisa apa saja, prosesnya berlangsung terus menerus, sumber belajarnya apa saja, Ciri ciri pelaksanaan pendidikan informal dalam keluarga yakni : pendidikan terjadi sepanjang waktu/ kapan saja, tidak terikat waktu, tidak ketat

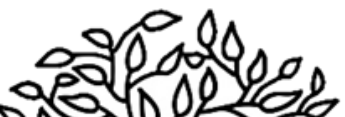




\section{| Dampak Masa Pandemi Covid19 Terhadap Fungsi Keluarga...}

auran, metode penyampaiannya berjalan naluriah, sangat fleksibel, tujuan tidak tersurat.

Ruh atau jiwa dari pendidikan yang dilakukan orang tua dalam keluarga adalah atas dasar cinta dan kasih sayang, tanggung jawab dunia dan akhirat, konsep bahwa anak adalah amanah dari Allah. Semua kegiatan pendidikan muncul dan berjalan secara naluriah dan bersifat alamiah/ mengalir.

Bahan materi pendidikan yang diberikan terutama moral dasar, agama bisa semua objek seperti peristiwa, kegiatan dalam rumah, pengalaman orang tua/ pengalaman orang lain sebagai contoh, hal yang baik dan buruk untuk ditiru dan dihindari, rencana masa depan, wawasan berfikir, ilmu pengetahuan, pelajaran sekolah, keterampilan dalam pekerjaan dirumah atau juga keterampilan tertentu yang didasarkan hobi dan kreativitas.

Proses pendidikan berjalan alamiah/ natural, tanpa beban, situasi pendidikan tidak tidak dirancang dengan jelas. Tujuan pendidikan tidak diungkapkan dengan jelas, tetapi implementasi pendidikannya sangat kuat. Hubungan anak dengan orang tua adalah hubungan bathiniah, naluriah dan kasihsayang, tanggung jawab baik kepada masadepan anak maupun tanggungjawab kepada sang khalik. Karena itu orangtua melakukan pendidikan secara penuh tanpa sekat. Ada tujuan mulia (Gunawan: 2020) yang mendasari gerak naluriah orangtua dalam mendidik. Karena itu dalam melihat dampak pandemi covid19 ini banyak sekali dampak positif dalam pendidikan keluarga. Dengan semua kelebihan ini maka proses penyampaian dapat lebih maksimal, karena anak mendapatkannya tanpa beban, pendekatannya dari kasihsayang orangtua, pelaksanaannya mengalir apa adanya, pelaksanaannya bisa langsung dan bisa juga diulur sesuai kemauan dan kondisi anak. Anak juga mengimplementasikan suruhan larangan dan lainnya dengan tanpa beban waktu.

Cara menyampaikannya dilakukan dengan beragam seperti reward dan funishment, suruhan dan larangan, contoh teladan,

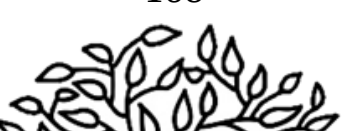


nasehat, bercerita, peringatan, teguran, pembinaan (pengawasan, monitoring, pengarahan, bimbingan dan motivasi), mempraktekkan cara mengerjakan pekerjaan rumah, dan lain lain.

Implementasi pendidikan dalam keluarga terjadi sepanjang hari Interaksi orangtua anak jauh lebih sering dari sebelumnya, waktu banyak tersedia, bahan yang akan diajarkan kepada anak dapat diambil dari berbagai objek baik formal yakni bahan pelajaran sekolah maupun non formal seperti pendidikan keterampilan. Untuk pelajaran sekolah orangtua menjadi guru pengganti bagi anak anaknya. Keterampilan hidup (Anwar: 2015) dapat diperoleh dari keterampilan dasar pada saat orangtua menyuruh anak untuk membantu mengerjakan tugas rumah mengerjakan pekerjaan rumah tangga sehari hari. Banyak ragam keterampilan tertentu didapat anak dalam rumah pada anak perempuan misalnya memasak, menanam memelihara tumbuhan, dan untuk anak laki laki misalnya memperbaiki kerusakan dalam rumah, bertukang. Pendidikan keterampilan umum seperti untuk laki laki dan anak perempuan menyangkut kebersihan kamar mandi dan kerapihan kamar tidur, serta kebersihan rumah dan lingkungannya. Pendidikan keterampilan khusus untuk anak laki laki melakukan perbaikan kerusakan kecil dalam rumah.. Anak dapat keterampilan mengerjakan tugas rumah dari contoh apa yang dilakukan orang tua maupun apa yang benar benar dipraktekkan orangtua tentang cara pengerjaannya. Ada juga keterampilan yang berdasarkan hobi serta bakat anak. Anak dapat mengembangkan semua potensi itu dirumah, orangtua memotivasi dan mendukung kegiatan yang positif tersebut. Dirumah anak bebas mengembangkan bakat, minat, hobi serta kreativitas. Waktu yang tersedia tidak terbatas bagi anak dan orangtua melaksanakan pendidikan keterampilan itu.

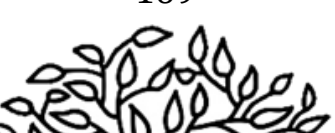


| Dampak Masa Pandemi Covid19 Terhadap Fungsi Keluarga...

Dirumah orangtua memberikan contoh dan teladan pendidikan agama (Nur Ahid :2010), moral dan akhlak. Tanggung jawab orangtua adalah mendidik anak. Pertanggungjawaban orangtua akan dituntut jika tugas mendidik anak diabaikan. Karena anak adalah amanah dari Yang Maha Kuasa. Baik buruknya seorang anak tergantung dari pendidikan yang dilakukan oleh orangtua. Pendidikan agama adalah sumber dari semua teori dan praktek nilai nilai pendidikan. Pendidikan nilai nilai ajaran agama adalah untuk bekal dan pedoman hidup serta sebagai penuntun keselamatan hidup dunia dan akhirat. Jika orangtua melaksanakan pendidikan kepada anaknya dengan didasarkan ajaran agama, maka anak akan selamat hidup didunia dan akan selamat hidup akhirat. Itulah tujuan hakiki dari pendidikan yang didasari agama. Pendidikan agama meputi pengetahuan dan seluk beluk agama. Dalam ajaran Islam misalnya tentang keimanan/ tauhid, fiqih, sejarah, dan akhlak. Di rumah anak melihat kebiasaan orangtua dan dijarkan juga oleh orangtua bagaimana praktek sholat, belajar mengaji, puasa, berdoa dan lain lain. Apabila orangtua belum menguasai/ belum mampu sepenuhnya mengajarkan dasar dasar agama, mereka bisa melihat dari ggole. Disana semua ilmu teori dan prektek tersedia.

Pendidikan untuk menanamkan kebiasaan yang baik, dapat dimaksimalkan karena anak berdiam diri dirumah. Dengan cara terus menerus orang tua mengingatkan anak untuk melakukan tugas rumah, tugas berkehidupan agama/ ibadah, menjaga kebersihan dan lain lain, orangtua telah mendidik anak secara komprehensif. Pendidikan kognitif, efektif, psikomotor dan pembiasaan bisa maksimal dilakukan orangtua dalam memanfaatkan masa anak diam di rumah.

Pendidikan moral seperti kejujuran, tanggung jawab adalah moral dasar yang wajib diterima anak sejak usia yang sangat dini. Nilai kejujuran yang ditanamkan dan harus dipraktekkan

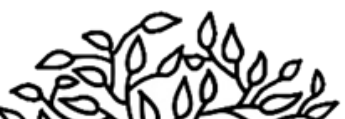


anak kejujuran. Nilai adalah akhlak yang paling dasar untuk semua akhlak lainnya. Dalam keluarga dapat dimaksimalkan pendidikan nilai kemandirian, anak mengisi waktu yang panjang ini dirumah dengan mengerjakan sendiri semua yang dalpat dikerjakannya sendiri. Apabila orangtua merasa dahulu belum maksimal,diera pandemic covid ini semua bisa dimaksimalkan.Pembentukan karakter seperti kepedulian social, kedisiplinan, kemandirian, kesederhanaan, etos kerja, kepercayaan diri, dan nilai dari karakter lainnya bisa dimaksimalkan lagi di era stay at home ini.

Dengan diam dirumah, baik anak dan orangtua terjadi interaksi yang terus menerus ( Pramudia : 2013). Ibu/ bapak melakukan pengawasan, memonitor, menyuruh, memberi teladan dapat berjalan kapan saja sepanjang hari dan dalam rumah. Orang tua dapat dan bebas melakukan tugas pendidikannya dengan beragam metode seperti nasehat, contoh, demonstrasi, teladan tingkahlaku dan teladan sikap, melakukan fungsi fungsi pembinaan ( Sudjana :2000)_terhadap anak yakni : motivasi, pengawasan, melakukan monitoring, melakukan evaluasi.

\section{DAFTAR PUSTAKA}

Husin Azizah., Saleh, Abdullah. 2020. Opportunities for the School System to Instill Environmental Values. Journal of Environmental Protection. 2019, 10, 1649-1656, https://www.scirp.org/journal/jep, ISSN Online: 21522219, ISSN Print: 2152-2197

Husin, Azizah, 2019. Planting Values for Saving Groundwater through Family Education. Journal of Environmental Protection, 2019, 10, 595-600, http://www.scirp.org/journal/jep. ISSN Online: 2152-2219, ISSN Print: 2152-2197

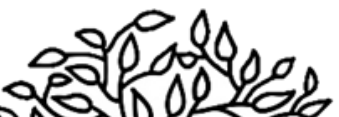


Sudjana, D.2004 Pendidikan Nonformal (Wawasan Sejarah Perkembangan Filsafat Teori Pendukung Asas) Bandung.. Falah Production

Republika.Co.Id Gunawan, Heri. 2020. Covid-19 dan Kembalinya Pendidikan dalam Keluarga. https://www.kompasiana.com/zul65979/5e98a9c4d541df 75c213e162/covid-19-dan-pendidikan-keluarga

Pramudia, Rahmat, Joni. 2013. Belajar Sepanjang Hayat. Bandung Konsep Kebijakan dan Aplikasi dalam Pendidikan Non Formal Menuju Masyarakat Berpengetahuan. Edukasia Press. Anwar 2015. Pendidikan Kecakapan Hidup. Bandung. Alfabeta.

Nur Ahid 2010.Pendidikan Keluarga Dalam Perspektif Islam: Pustaka Pelajar. Yogyakarta.

Sudjana 2000.Manajemen program pendidikan untuk pendidikan luar sekolah dan pengembangan sumber daya manusia. Falah Production, Bandung.

Mahmud, Gunawan, Yulianingsih. 2013, Pendidikan Agama Islam dalam Keluarga: Sebuah Panduan lengkap bagi Para Guru, Orang Tua, dan Calon. Akademia Permata Jakarta. Isbn: 6028381-47-0 .

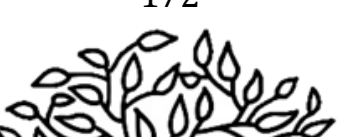




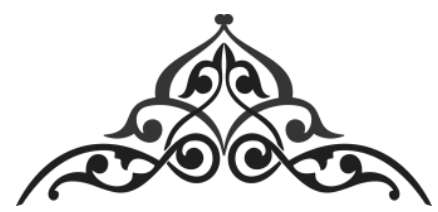

KELUARGA SEBAGAI ROLE MODEL
PELAKSANAAN GERMAS DI ERA NEW

NORMAL

\author{
Merita Eka Rahmuniyati, SKM., M.Gizi² \\ Universitas Respati Yogyakarta
}

\begin{abstract}
"Keluarga dapat memaksimalkan pencegahan virus corona dengan GERMAS. Apabila seluruh keluarga di

Indonesia dapat melaksanakan langkah GERMAS dengan baik, maka akan terbentuk masyarakatyang sehat.Dibutuhkan komitmen keluarga sehingga keluarga dapat menjadi role model pelaksanaan GERMAS di era new normal"
\end{abstract}

Dandemi Covid-19 merupakan musibah bagi seluruh
kehidupan di dunia. Indonesia menjadi salah satu dari beberapa negara di dunia yang telah melaporkan munculnya kasus positif covid-19 mulai Maret 2020. Sudah hampir empat bulan ini seluruh media massa menyajikan berita mengenai Covid-19, dimana berita yang diulas selalu menjadi trending topik, hangat diperbincangkan bahkan memunculkan berbagai respon dari masyarakat. Begitu juga dampak buruk yang ditimbulkan dari Covid-19 ini, hampir seluruh sektor terkena

2 Merita Eka Rahmuniyati lahir di Kudus, 05 Maret 1983. Penulis menyelesaikan gelar Magister Ilmu Gizi di Universitas Diponegoro (2013). Penulis mengawali karir sebagai staf pengajar di Program Studi Kesehatan Masyarakat Program Sarjana di Universitas Respati Yogyakarta (2015). Penulis mengajar mata kuliah yang berkaitan dengan gizi masyarakat serta keilmuan lainnya. Penulis juga aktif sebagai peneliti dan melakukan kegiatan pengabdian kepada masyarakat di bidang gizi masyarakat. 


\section{"Y | Keluarga Sebagai Role Model Pelaksanaan Germas di Era...}

dampak adanya Covid-19, baik dunia kesehatan, pariwisata, pendidikan, perekonomian, dan sektor - sektor kehidupan lainnya.

\section{Mengenal Covid-19}

Coronavirus adalah penyebab dari Covid-19. Gejala awal dari Covid-19 munculnya gejala batuk, pilek, demam, gangguan pernapasan, namun ada juga yang tidak muncul gejala, dan apabila kondisi parah bisa menyebabkan gagal nafas dan berakibat pada kematian. Penularan Covid-19 melalui droplets/percikan batuk dan bersin. Kontak pribadi seperti menyentuh dan berjabat tangan, menyentuh benda yang terdapat virus, kemudian orang sehat tersebut menyentuh mulut, hidung atau mata sebelum cuci tangan. Virus tersebut dapat tinggal di permukaan benda dan hidup selama beberapa waktu (hari/jam). Virus dapat berpindah secara langsung melalui droplet orang yang terinfeksi.

Sejauh ini, Covid-19 ini belum ditemukan obat/vaksinnya, namun Covid-19 saat ini telah menjadi pandemi yang menyebabkan banyak kematian di dunia maupun di Indonesia, bahkan sampai saat ini kasusnya masih terus meningkat. Pemerintah telah melakukan upaya untuk menghentikan penularan dan pencegahan dari Covid-19. Pemerintah selalu kontinue melakukan sosialisasi dan edukasi supaya masyarakat memahami apa saja yang harus dilakukan supaya terhindar dari Covid-19. Edukasi yang diberikan berupa 1) Sering mencuci tangan pakai sabun, 2) Bekerja, belajar, beribadah di rumah, 3) Jaga jarak dan hindari kerumunan, 4) Tidak berjabat tangan, 5) Pakai masker bila sakit atau bila terpaksa harus keluar rumah/berada di tempat umum, 6) Makan makanan yang bergizi seimbang, 7) Istirahat yang cukup dan rajin olahraga (Widyawati, 2020). 
Pandemi Covid-19 berhasil mengubah perilaku dan kebiasaan yang kita lakukan baik di rumah, sekolah, tempat kerja, dan tempat wisata, dimanapun kita berada. Aktivitas kita sangat terbatas karena coronavirus, sehingga membuat kita menjadi tidak produktif dan dapat menimbulkan dampak buruk bagi roda perekonomian keluarga, masyarakat, bangsa dan negara.

\section{GERMAS di Era New Normal}

Menyongsong masa depan yang lebih baik, mau tidak mau, kenyataannya, masyarakat Indonesia dipaksakan hidup dengan era new normal (tatanan kehidupan baru) atau adaptasi kebiasaan baru (berdamai dengan Covid-19). Berdamai yang dimaksud dengan tetap menggunakan protokol kesehatan yang tepat saat menjalankan aktivitas dimanapun.

New Normal merupakan suatu tindakan atau perilaku yang dilakukan oleh masyarakat dan semua institusi yang ada di wilayah tersebut untuk melakukan pola harian atau pola kerja atau pola hidup baru yang berbeda dengan sebelumnya. Bila hal ini tidak dilakukan, akan terjadi risiko penularan. Tujuan dari New Normal adalah agar masyarakat tetap produktif dan aman dari Covid-19 di masa pandemi. Dengan adanya adaptasi kebiasaan baru kita bisa bekerja, belajar dan beraktivitas dengan produktif di era Pandemi Covid-19 (Irawati, 2020).

Kebiasaan baru untuk hidup lebih sehat harus terus menerus dilakukan oleh individu, keluarga dan masyarakat. Kita dituntut untuk dapat beradaptasi dengan kebiasaan baru sehingga suatu saat akan terbentuk suatu norma sosial yang baru dalam kehidupan sehari hari. Kebiasaan yang mendukung penularan Covid-19 wajib ditinggalkan untuk mengurangi risiko penularan Covid-19, seperti kebiasaan bersalaman, cium tangan, kumpul bersama teman, malas cuci tangan.

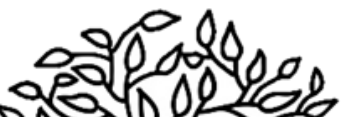




\section{" | Keluarga Sebagai Role Model Pelaksanaan Germas di Era...}

Sembari mempersiapkan adaptasi kebiasaan baru di era new normal, tentunya kita akan mengingat adanya sebuah program kesehatan Gerakan Masyarakat Hidup Sehat (GERMAS) yang dicanangkan pada tahun 2016 silam. Tujuan GERMAS adalah menjalani hidup yang lebih sehat. Program GERMAS terdapat tujuh langkah yang merupakan bagian penting dari pembiasaan pola hidup sehat dalam masyarakat guna mencegah berbagai masalah kesehatan yang beresiko dialami oleh masyarakat Indonesia. Tujuh langkah tersebut adalah : 1) Melakukan aktivitas fisik, 2) Makan buah dan sayur, 3) Tidak merokok, 4) Tidak mengkonsumsi minum beralkohol, 5) Melakukan cek kesehatan berkala, 6) Menjaga kesehatan lingkungan, 7) Menggunakan jamban.

Gaya hidup sehat akan memberi banyak manfaat, mulai dari peningkatan kualitas kesehatan hingga peningkatan produktivitas. Gaya hidup sehat adalah kebiasaan hidup dengan lingkungan yang bersih dan sehat. Sudah saatnya kita mulai kembali menjalankan GERMAS, karena GERMAS ini sebagai bagian dari hidup dan gaya hidup di era new normal. Hal tersebut menunjukkan bahwa sebenarnya kebiasaan perilaku hidup bersih dan sehat sudah kita lakukan sebelum terjadinya pandemi Covid-19 dan saat ini kita akan terus melakukannya supaya terhindar dari Covid-10.

\section{Keluarga sebagai Role Model GERMAS di Era New Normal}

Keluarga sebagai sumber kekuatan untuk membangun bangsa dan negara. Keluarga menjadi sumber yang selalu menghidupkan, memelihara dan memantapkan serta mengarahkan kekuatan tersebut sebagai perisai dalam menghadapi persoalan yang terjadi. Menghadapi serbuan virus Covid-19, virusnya tidak terlihat, berpindah antar manusia, terinfeksi tanpa gejala, sampai kini belum ada obat dan vaksinnya, maka melakukan tindakan menghindar dari interaksi

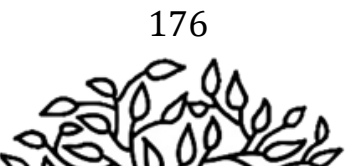


antara manusia dan berdiam di rumah adalah perisai pilihan. Rumah yang efektif sebagai tempat perlindungan adalah rumah yang dihuni keluarga berkualitas. Keluarga yang berkualitas akan memiliki ketahanan terhadap apapun tantangannya (Siregar, 2020).

GERMAS merupakan suatu tindakan sistematis dan terencana yang dilakukan secara bersama-sama oleh seluruh komponen bangsa dengan kesadaran, kemauan dan kemampuan berperilaku sehat untuk meningkatkan kualitas hidup. GERMAS merupakan gerakan nasional yang tidak bisa hanya mengandalkan peran sektor kesehatan saja, namun juga membutuhkan peran sektor lainnya. Dengan Sosialisasi GERMAS diharapkan mampu mengajak masyarakat untuk membudayakan hidup sehat, agar mampu mengubah kebiasaan atau perilaku tidak sehat (Rahmawaty et al., 2019).

GERMAS merupakan gerakan yang mengedepankan upaya promotif dan preventif tanpa mengesampingkan upaya kuratif dan rehabilitatif. Pelaksanaan GERMAS harus dimulai dari keluarga, karena keluarga adalah bagian terkecil dari masyarakat yang membentuk kepribadian. Keluarga itulah yang kemudian berkumpul berada di masyarakat. Komitmen pelaksanaan GERMAS dari keluarga dan masyarakat untuk mempraktikkan pola hidup sehat akan membentuk karakter yang sehat, terutama saat beradaptasi dengan era baru pasca Covid-19. GERMAS merupakan wujud perilaku nyata dari kebiasaan lama yang harus dilakukan di era new normal, kebiasaan lama yang akan menjadi adaptasi kebiasaan baru. Adaptasi kebiasaan baru tersebut dimulai dari keluarga sebagai role model pelaksanaan GERMAS di era new normal.

Beberapa cara yang dapat dilakukan keluarga supaya terhindar dari virus corona (Covid-19) dengan membiasakan GERMAS, sebagai berikut :

1. Makan dengan gizi yang seimbang

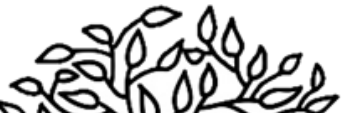


| Keluarga Sebagai Role Model Pelaksanaan Germas di Era...

2. Rajin oleharaga dan istirahat yang cukup

3. Cuci tangan pakai sabun

4. Jaga kebersihan lingkungan

5. Tidak merokok

6. Gunakan masker bila batuk atau tutup dengan lengan atas bagian dalam

7. Minum air mineral 8 gelas/hari

8. Makan makanan yang dimasak dan jangan makan daging dari hewan yang berpotensi menularkan

9. Bila demam dan sesak nafas segera ke fasilitas kesehatan

10. Jangan lupa berdoa

(Kementerian Kesehatan Republik Indonesia, 2020)

Keluarga dapat memaksimalkan cara tersebut untuk mencegah virus corona dengan GERMAS. Dengan meningkatkan kesehatan diri sendiri dan keluarga, dapat menciptakan lingkungan yang bersih dan dapat mengurangi risiko terkena penyakit. Apabila seluruh keluarga di Indonesia dapat melaksanakan langkah GERMAS dengan baik, maka akan terbentuklah masyarakat yang sehat. Oleh sebab itu dibutuhkan komitmen keluarga sehingga keluarga dapat menjadi role model pelaksanaan GERMAS di era new normal.

\section{Daftar Pustaka}

Irawati, T. (2020) Menuju Adaptasi Kebiasaan Baru. Available at: http://promkes.kemkes.go.id/menuju-adaptasi-kebiasaanbaru (Accessed: 28 June 2020).

Kementerian Kesehatan Republik Indonesia (2020) Selamat Datang di Direktorat Promosi Kesehatan Dan Pemberdayaan Masyarakat. Available at: http://promkes.kemkes.go.id/ (Accessed: 30 June 2020).

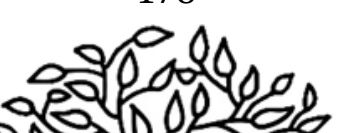


Rahmawaty, E. et al. (2019) 'Sosialisasi dan Harmonisasi Gerakan Masyarakay Hidup Sehat (Germas) dan Program Indonesia Sehat dengan Pendekatan Keluarga (PIS-PK) di Kota Sukabumi', LINK. UPPM Poltekkes Kemenkes Semarang, 15(1), pp. 27-31. Available at: http://ejournal.poltekkessmg.ac.id/ojs/index.php/link/article/view/4385/1211

(Accessed: 15 August 2019).

Siregar, A. (2020) Keluarga Berkualitas Cegah Tangkal Covid-19 \#Reinstall Kehidupan. Available at: http://promkes.kemkes.go.id/keluarga-berkualitas-cegahtangkal-covid-19-reinstall-kehidupan (Accessed: 30 June 2020).

Widyawati (2020) Cara Cegah Penularan Covid-19 di Masyarakat Sehat Negeriku. Available at: http://sehatnegeriku.kemkes.go.id/baca/rilismedia/20200331/5133667/cara-cegah-penularan-covid19-masyarakat/ (Accessed: 28 June 2020). 
| Keluarga Sebagai Role Model Pelaksanaan Germas di Era... 


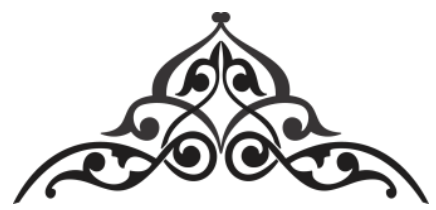

\title{
PERAN KELUARGA DALAM PENDIDIKAN ANAK: PROGRAM MAGHRIB MENGAJI DI ERA NEW NORMAL
}

\section{Muhammad Al Mansur² STAIN Bengkalis}

\begin{abstract}
"Jika Ibu adalah madrasah pertama, maka ayah adalah kepala sekolahnya. Keluarga ibarat sebuah lembaga pendidikan. Harus selalu ada inovasi dan pengembangan diri, terus belajar tanpa gengsi demi menciptakan generasi yang unggul dan rabbani"
\end{abstract}

$\mathrm{V}$ irus Corona atau coronavirus merupakan jenis virus baru yang disebut dengan Novel Coronavirus (COVID-19). Virus ini pada awal mulanya diidentifikasi di daerah Wuhan, Cina pada bulan Desember 2019 dan kemudian dengan cepat beredar di seluruh dunia. Adapun gejala yang diakibatkan dari virus covid 19 ini adalah seperti demam, kesulitan bernafas (gangguan pernafasan), batuk dan serangan terhadap paru-paru. Meningkatnya angka infeksi dan angka kematian di Cina pada Februari 2020 membuat Organisasi Kesehatan Dunia (WHO) menyatakan wabah covid-19 dari Tiongkok merupakan darurat kesehatan internasional dan mulai menyebar ke seluruh negara dan termasuk Negara Republik Indonesia.

2 Muhammad Al Mansur lahir di Bengkalis, 10 Mei 1991, penulis ${ }^{4}$ merupakan Dosen STAIN Bengkalis dalam bidang Hukum Keluarga Islam (Ahwal Syakhshiyyah), penulis menyelesaikan gelar Sarjana Syari'ah di Fakultas Syariah dan Hukum, Universitas Islam Negeri (UIN) Syarif HIdayatullah Jakarta (2013), sedangkan gelar Master Of Islamic Studies diselesaikan di Universiti Kebangsaan Malaysia di Jabatan Syari'ah, Fakulti Pengajian Islam (2017). 
Peran Keluarga dalam Pendidikan Anak: Program Maghrib...

Sejak awal masuknya covid-19 di awal tahun 2020 ke Indonesia, banyak sekali tindakan cepat yang diambil oleh Presiden dan jajarannya. Diantaranya adalah langsung membentuk tim gugus tugas percepatan penanganan covid-19. Mulai dari Rapid Test massal identifikasi penyebaran covid-19, gunakan fasilitas obrolan elektronik chatbot covid-19 melalui whatsapp, menerapkan jaga jarak (Sosial distancing) dan tidak mendatangi kerumunan, menerapkan WFH (Work From Home) bagi semua lembaga, menerapkan protokol kesehatan sesuai standar covid hingga penerapan Pembatasan Ssosial Berskala Besar (PSBB) bagi wilayah yang tergolong pada zona merah.

Banyak sekali dampak yang ditimbulkan oleh covid-19 ini bagi seluruh dunia dan khususnya bagi Negara Indoneisa. Bukan hanya dari segi kesehatan, Ekonomi, Pendidikan, Pembangunan dan Sosial juga turut terkena dampak Covid-19 ini. Dampak dalam bidang ekonomi, Indoneisa sudah diperkirakan mengalami kelemahan pertumbuhan ekonomi hingga di bawah 5\% pada kuartal I-2020 terkait dengan negara-negara mitra dagang terbesar Indoneisa yang terinfeksi covid-19 dan mempengaruhi sistem dagang ekspor/impor dan penyumbang wisatawan terbesar Indonesia. Adapun dampak dari segi pendidikan adalah pelaksanaan sistem pembelajaran daring/jarak jauh dan proses belajar dilaksanakan dari rumah. Dari mulai TK, SD, SMP, SMA dan Perguruan Tinggi melaksanakan sistem belajar secara daring. Hal ini sesuai dengan Surat Edaran Menteri Pendidikan dan Kebudayaan Nomor 4 tahun 2020 pada tanggal 24 maret 2020.

Berdasarkan edaran Menteri tersebut, seluruh orang tua harus ekstra mengawasi anak-anaknya belajar dari rumah. Baik untuk pelajaran umumnya di tingkat SD, SMP atau SMA maupun di tingkat keagamaan seperti Madrasah Diniyah Awwaliyah (MDA) maupun belajar mengaji al-Qur'an. Sejak mula berkembangnya Islam, pendidikan mengaji al-Quran selalu

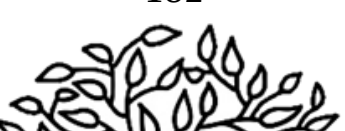


diadakan di setiap rumah ibadah seperti, masjid, surau, mushalla, langgar dan lain-lain. Kegiatan mengaji biasanya dimulai dari ba'da ashar hingga setelah maghrib dan Isa. Mengaji juga tergolong menjadi lembaga pendidikan anak non-formal bagi semua anak-anak kaum muslim. Program maghrib mengaji atau gerakan Masyarakat Maghrib Mengaji (GEMAR) juga merupakan program nasional Kementerian Agama. Tepatnya pada tanggal 30 Maret 2011, Menteri Agama RI Suryadharma Ali mencetuskan kembali kegiatan Maghrib Mengaji melalui program GEMAR dengan tujuan untuk membiasakan kembali mengaji kitab suci Al-Qur'an sesudah sholat maghrib yang saat ini mulai hilang tergerus oleh perkembangan dan kemajuan teknologi dan informasi.

Program maghrib mengaji bukan hanya bagi kalangan masyarakat dewasa, namun juga bagi pendidikan non-formal mengaji anak. Baik anak- anak yang baru mulai mengetahui dan belajar huruf "Hijaiyyah" (Anak TK) dengan metode belajar "Iqra' ", maupun yang sudah masuk ke jenjang membaca atau belajar Al-Qur'an (Anak-anak SD/SMP-MTS). Mengenai metode pembelajaran al-Qur'an, terdapat beberapa metode yaitu dinataranya adalah menggunakan metode atau buku IQRO' karangan As'ad Humam, seorang ulama asal Yogyakarta dan dikembangkan Tim Tadarus AMM. Buku ini terbit pertama kali pada tahun 1990-an (Edisi Pertama). Selain dari itu ada juga metode belajar al-Qur'an bagi anak-anak dan kalangan dewasa adalah menggunakan metode baca Al-Qur'an Qira'ati. Metode ini ditemukan oleh KH. Dachlan Salim Zarkasyi Semarang Jawa Tengah. Metode ini mulai disebarkan pada tahun 1970-an.

Seiring dengan perkembangan waktu dan zaman, terdapat pergeseran waktu dan tempat pelaksanaan program mengaji. Mengenai waktu mengaji berubah dari setelah shalat Asar menjadi setelah shalat maghrib atau Isa. Hal ini disebabkan oleh waktu belajar anak-anak yang full dari pagi hingga sore hari

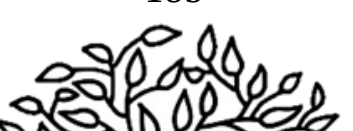


sehingga tidak memungkinkan untuk dipaksakan mengaji pada sore hari disaat waktu istirahat dan bermain anak-anak. Pada pagi hingga siang hari, anak-anak mengikuti pembelajaran di sekolah dasar dan pada sore harinya mengikuti pembelajaran di MDA (Madrasah Diniyah Awwaliyah). Manakala tempat mengaji juga mulai berubah yang sebelumnya dilaksanakan di masjid atau rumah ibadah, sekarang lebih banyak dilaksanakan di rumah guru atau orang alim yang menguasai bidang ilmu Qur'an, baik dari segi tajwid, fashohah, hingga seni tilawah.

Pada masa pandemik Covid-19, terutama di Kecamatan Bengkalis, Kabupaten Bengkalis, Riau, seluruh tempat program maghrib mengaji juga turut mengalami imbasnya, yaitu mengikuti program pemerintah untuk tidak melaksanakan kegiatan belajar mengajar secara tatap muka melainkan belajar mengaji di rumah masing-masing demi untuk memutuskan rantai penyebaran covid-19. Biasanya setelah maghrib ramai anak-anak berbondong-bondong pulang dari shalat maghrib di masjid atau surau langsung mendatangi rumah guru ngaji tersebut, namun pada saat pandemi, pemandangan itu tidak dijumpai lagi. Efek lainnya juga dirasakan guru ngaji tersebut, biasanya mendapatkan tambahan pemasukan dari anak-anak yang datang belajar mengaji, namun disaat pandemi ini, tidak ada tambahan pemasukan baginya, bahkan banyak guru ngaji yang juga menjadi kesusahan disebabkan pandemi covid-19 ini.

Pada masa pandemi ini juga, banyak keluarga yang mengalami kesusahan dalam mendidik dan mengajarkan anakanaknya mengaji. Tidak sedikit dikalangan orang tua, baik sang ayah maupun ibu dari anak-anak yang tidak bisa membaca AlQur'an. Selama ini mereka hanya mengantarkan anaknya ke guru ngaji dan mengetahui anaknya bisa mengaji, namun pada saat covid ini mereka kebingungan untuk melanjutkan pengajaran mengaji di rumah. Tidak sedikit juga orang tua tidak bisa menyambung huruf demi huruf hijaiyah dan membaca Al-Qur'an,

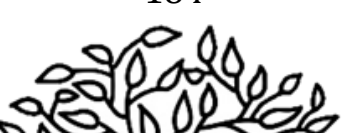


sehingga tidak bisa mengajarkan anaknya mengaji dan pada akhirnya anak-anak menjadi tidak belajar mengaji dan mengulang kaji.

Peran keluarga pada saat pandemic covid-19 ini seharusnya harus lebih ditingkatkan, karena peran keluarga merupakan kategori kebutuhan khusus atau primer. Seharusnya pada saat ini lah menjadikan rumah sebagai tempat untuk belajar bagi anak-anaknya. Anggota keluarga di rumah seharusnya menjadi perangkat sekolah, yang siap untuk memfasilitasi kebutuhan belajar bersama. Orang tua (ayah dan ibu) harus bersinergi mengajarkan anak-anak mengaji di rumah. Paling tidak jika orang tua tidak bisa mengaji dengan baik, tetapi menggiring anaknya untuk mengulang mengaji harus tetap diupayakan. Sehingga anak-anak akan menjadi fasih membaca al-Qur'an.

Seiring dengan perkembangan teknologi yang canggih, seharusnya orang tua tidak perlu risau dan gengsi untuk meningkatkan kemampuan demi mengajarkan anaknya terutama dalam mengajarkan membaca al-Qur'an. Orang tua harus berusaha dan berupaya melalui media online belajar mengaji al-Qur'an dan menggunakan media video youtube dalam mengajarkan anaknya mengaji. Banyak sekali video tutorial belajar mengaji baik menggunakan metode Iqro' maupun Qiro'ati. Sistem pembelajaran menggunakan media online seperti video di youtube bisa digunakan pada masa pandemi covid-19 ini untuk melanjutkan pengajaran mengaji dari para guru ngaji. Hendaknya para orang tua menyesuaikan dengan batas mengaji anak-anak dengan guru ngajinya dan menyesuaikan dengan video pembelajaran yang tersedia di Youtube.

Demi menjaga kesempurnaan ilmu mengaji al-Qur'an, para orang tua juga harus bisa memilih video tutorial mengaji alQur'an yang betul-betul dijelaskan oleh para ustaz yang ahli dan tidak asal memilih video yang ada. Karena hal ini bertujuan agar tidak terjadi kerancuan bagi anak-anak yang akan

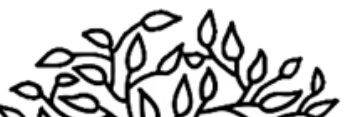


mempelajarinya, sehingga kesempurnaan ilmu mengaji al-Qur'an terhadap anak-anak di masa pandemi covid-19 ini tetap terjaga.

Jika Ibu adalah madrasah pertama, maka ayah adalah kepala sekolahnya. Keluarga ibarat sebuah lembaga pendidikan. Harus selalu ada inovasi dan pengembangan diri, terus belajar tanpa gengsi demi menciptakan generasi yang unggul dan rabbani.

\section{DAFTAR PUSTAKA}

Darmadi. 2018. Mendidik Adalah Cinta: "Menjelajah Pendidikan Ramah Anak di Rumah dan Sekolah". Surakarta : CV. Oase Group.

Burhanuddin, Khairul Ihsan., Abdi, Muhammad Nur. .2020. Ancaman Krisis Ekonomi Global dari Dampak Penyebaran Virus Corona (Covid-19). Jurnal AkMen. Vol. 17 Nomor 1 Maret 2020.

https://covid19.go.id/

https://www.kemdikbud.go.id/main/blog/2020/03/se-

mendikbud-pelaksanaan-kebijakan-pendidikan-dalammasa-darurat-penyebaran-covid19

https://jabar.kemenag.go.id/portal/read/kakemenag-kotabandung-mari-kita-sukseskan-program-maghrib-mengaji

https://id.wikipedia.org/wiki/Iqro

http://www.qiroatipusat.or.id/p/metode-pembelajaranqiroati.html

Wahyu, Fadjri. . 2018. Pengembangan Masyarakat Islam: Program maghrib mengaji Kecamatan Koto Tangah, Padang, Sumatra Barat.. Jurnal ALFUAD. Vol.1, No.2 2018 ISSN: 2714-7606

Wei, Hengbo Zhu Li., Niu, Ping. 2020. The Novel Coronavirus Outbreak in Wuhan, China. Journal Global Health Research and Policy. Doi: 10.1186/s41256.020.00135.6. https//doi.org/10.1186/s41256-020-00135-6

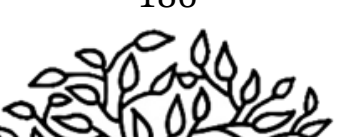


Muhammad Al Mansur. | 


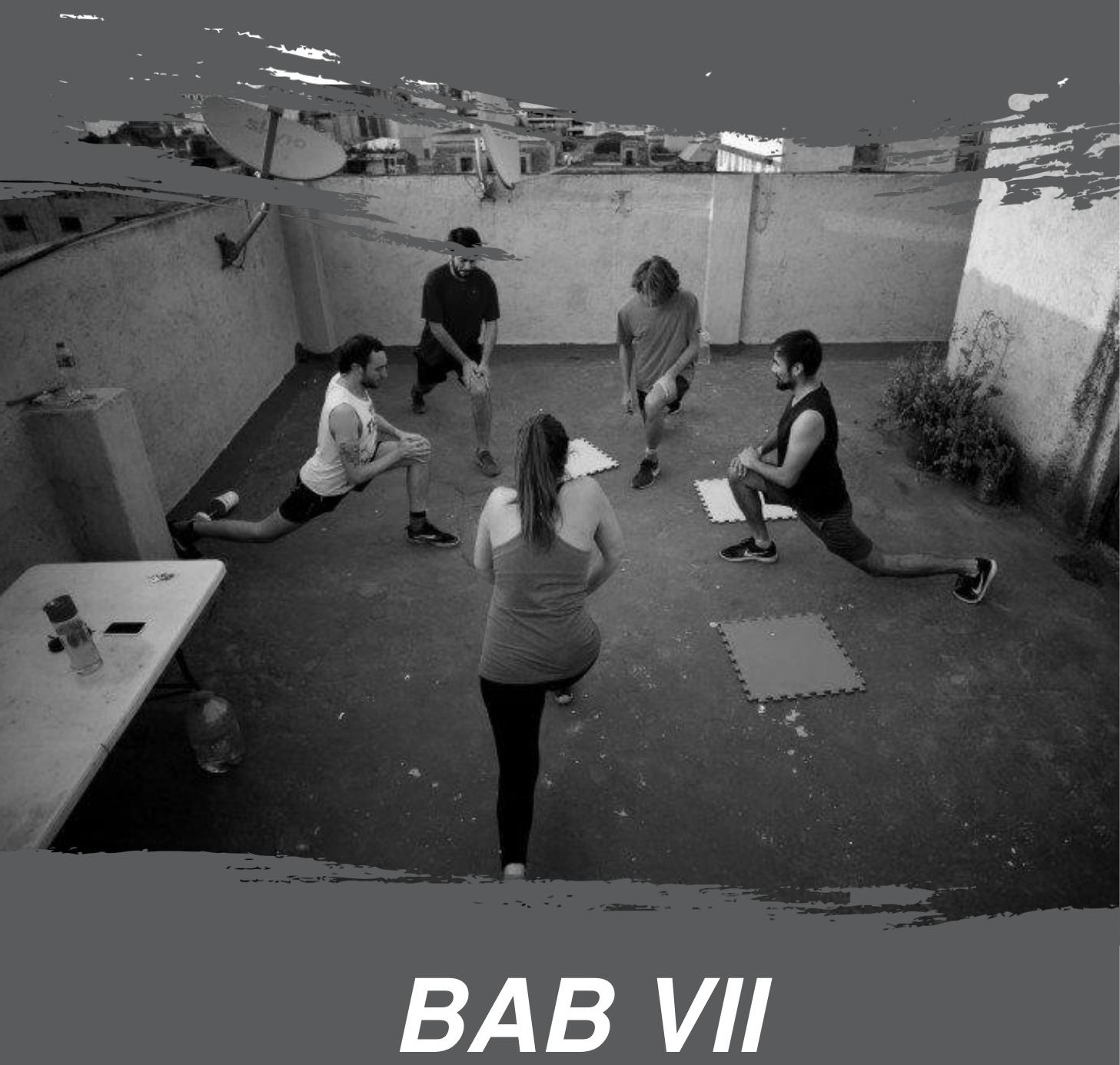

AKTIFITAS SELAMA PANDEMI 


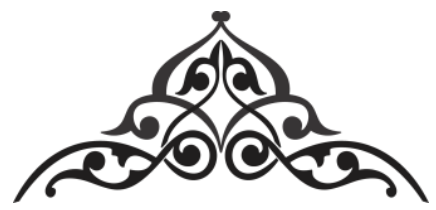

\title{
ARTI PENTING PEMBELAJARAN KALIGRAFI ARAB UNTUK MENUMBUHKAN KREATIVITAS SENI ANAK DI ERA PANDEMI COVID-19
}

\author{
Nurul Huda, S.S., M.Pd.I. ${ }^{2}$ \\ PBA FITK UIN Sunan Kalijaga Yogyakarta
}

"Kaligrafi selama ini hanya dianggap sebagai sebuah bentuk hasil karya seni semata. Padahal kaligrafi meruupakan salah satu dari khazanah kebudayaan Islam yang mengagungkan. Bukan hanya memiliki unsur keindahan, namun kaligrafi mengandung makna religius dan spiritual yang tinggi"

$\mathrm{D}$ i tengah Pandemi Covid 2019 ini banyak hal ataupun kreativitas yang terus dan perlu digali salah satunya sebagai upaya memperkaya hal-hal yang bermanfaat bagi orang banyak salah satunya untuk anak-anak. Tulisan ini penulis paparkan berkenaan dengan beberapa anggapan yang salah mengenai khat atau kaligrafi Arab. Di mana selama ini, kaligrafi hanya dianggap sebagai sebuah bentuk hasil karya seni semata, sehingga nilainilai pada proses pembelajarannya atau peranan yang sebenarnya ada di dalamnya terabaikan. Maka di dalam hal ini

2 Nurul Huda Pengajar Kaligrafi, Pengajar di Prodi PB§ FITK UIN Sunan Kalijaga Yogyakarta serta Aktif di LKP Jogja Kaligrafi DI Yogyakarta sejak 2011 hingga sekarang. Tulisan ini disampaikan pada pelatihan Metodologi Pengajaran Khat di Rumah Tahfidz As-Salam Mranggen Tegal Mati Sleman DIY 27 Maret 2016. Belum pernah dipublish dan diikutsertakan dalam penulisan antologi buku di era Pandemi Covid 2019 tahun 2020. 
penulis mencoba memaparkan sekelumit mengenai peranan pembelajaran kaligrafi pada anak. Meskipun tulisan ini sudah lama tetapi menurut hemat penulis masih relevan dengan kondisi saat ini.

Seni tulis menulis Arab (khat) atau yang dikenal juga dengan sebutan "kaligrafi" merupakan salah satu dari khazanah kebudayaan Islam yang mengagungkan. Seni kaligrafi yang berkembang mulai abad ke-3 Hijriyah ini memang bukan hanya memiliki unsur keindahan, namun mengandung makna religius dan spiritual yang tinggi. Makna spiritual yang bermuara dari religiusitas kaligrafi inilah yang membuat kaligrafi dapat bertahan dan mampu bersaing dengan seni-seni yang lain.

kaligrafi secara etimologi berasal dari dua suku kata bahasa Yunani, yakni Kalios yang berarti indah dan graphein yang berarti menulis atau tulisan. Adapun istilah kaligrafi dalam bahasa Inggris adalah calligraphy yang berarti tulisan indah dan seni menulis indah. Kaligrafi dalam bahasa Arab sering disebut khath yang berarti garis, dan tulisan indah, dan jamaknya (bentuk plural) adalah khuthûth. Ahli khat Arab disebut khaththath. Kata Arab sendiri dinisbahkan pada asal tulisan tersebut, yaitu Arab sesuai dengan perkembangan di wilayah itu, dengan orang yang ahli dalam kaligrafi disebut kaligraf atau kaligrafer.

Isma'il Raji' al-Faruqi -Budayawan dan Intelektual muslimmenyatakan, bahwa; seni kaligrafi dapat mengubah medium ultimat dari pemahaman diskursif - yaitu simbol logika atau abjad - menjadi materi seni indrawi dan medium estetik yang menghasilkan intuisi estetik sui generis.

Hal senada juga diungkapkan oleh D. Sirojuddin AR Kaligrafer Indonesia- dalam bukunya "Seni Kaligrafi Islam", bahwa; "adanya nilai yang dipancarkan pada huruf dan kesugguhan seniman muslim untuk mencelup masjid, rumah, cawan hingga baju yang menjadi miliknya dengan pesan-pesan

191

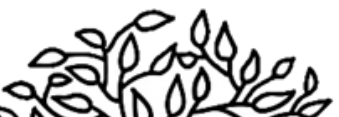


Arti Penting Pembelajaran Kaligrafi Arab untuk Menumbuhkan...

al-Qur'an, bahkan di Indonesia lukis kaligrafi sudah menjadi perbendaharaan komunikasi untuk menyampaikan isi hati, pikiran dan pesan para pelukis kaligrafi"

Seni kaligrafi Arab mengalami perkembangan yang pesat di Indonesia, bahkan sangat menggembirakan. Hal ini dapat dibuktikan dengan banyaknya kegiatan-kegiatan yang menggemakan keindahan seni kaligrafi, baik itu melalui musabaqah, pameran, festival maupun dalam bentuk seminar dan diskusi yang terkemas dalam sebuah sanggar atau lembaga. Perkembangan kaligrafi yang sangat pesat tersebut memang perlu disyukuri, ditambah lagi dengan banyaknya para pelukis yang menggandrungi kaligrafi sebagai objek lukisannya. Akan tetapi perkembangan itu tidak cukup disyukuri dengan mengucap "al-hamdulillah" semata, namun perlu dibaca ulang bagaimana proses menuju prestasi tersebut, "mengapa" dan "bagaimana" selanjutnya.

Oleh karena itu dalam tulisan ini mencoba menelaah bagaimana seharusnya kegiatan keilmuan plus kesenian kaligrafi Arab dapat diajarkan sejak dini. Sebab hal itu akan mempengaruhi kegiatan anak, atau dalam kaitannya dengan ranah yang diutarakan oleh Bloom, yang terdiri dari ranah kognitif, psikomotorik, dan afektif. Dalam tulisan ini penekanan arti penting dan peranannya adalah terkait dengan pembelajaran Pendidikan Agama Islam di sekolah dasar dan pembelajaran bahasa Arab untuk anak.

\section{Peranan Kaligrafi dalam Pendidikan Agama Islam dan Praktiknya}

Kegiatan berkaligrafi atau khat diberikan untuk menumbuhkan rasa keindahan dan artistik sehingga membentuk sikap kreatif, apresiatif dan kritis. Kaligrafi sebagai salah satu cabang seni Islam memberikan kesempatan kepada peserta didik

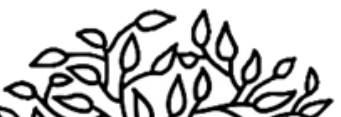


untuk memperoleh pengalaman berapresiasi dan berkreasi serta menghasilkan suatu produk benda yang bermanfaat langsung. Perwujudan sikap kreatif, apresiatif dan kritis diperoleh melalui pembelajaran yang memuat aktivitas menanggapi dan berkreasi seni. Dalam dunia anak-anak, kaligrafi bagi mereka merupakan salah satu penyaluran hobi dan bakat seni yang dapat diwujudkan menjadi hasil karya yang patut dipertimbangkan serta dapat dimanage menjadi sebuah kegiatan yang positif baik secara individu maupun berkelompok.

Kaligrafi juga dapat berperan membentuk kepribadian peserta didik secara menyeluruh, harmoni, mencakup logika, etika, estetika dan artistik dalam pengembangan kreatifitas, kepekaan rasa dan indera, serta beretika. Dan seni ini akan memenuhi kebutuhan perkembangan peserta didik dalam mencapai kecerdasan emosional (EQ), kecerdasan intelektual (IQ), kecerdasan adversitas (AQ) dan kreativitas (CQ), serta kecerdasan spiritual dan moral (ESQ).

Kaligrafi bagi peserta didik yang masih anak-anak terdiri atas seni menulis, mewarnai, serta berkarya yang memiliki keilmuan masing-masing dan disusun sesuai kebutuhan peserta didik mencakup: unsur-unsur, prinsip-prinsip, proses dan teknik berkarya, nilai budaya dan tidak mengesampingkan aspek fungsi, serta sesuai dengan konteks sosial-budaya masyarakat, menumbuhkan saling memahami, menghargai dan saling menghormati.

Pembelajaran kaligrafi memiliki fungsi dan tujuan menumbuhkembangkan potensi, sikap dan keterampilan. Secara rinci, fungsi dan tujuan kaligrafi adalah:

1. Mengembangkan kemampuan dan ketrampilan peserta didik melalui penelaahan jenis, bentuk, dan sifat fungsi, alat, bahan, proses dan teknik dalam membuat prosuk karya seni.

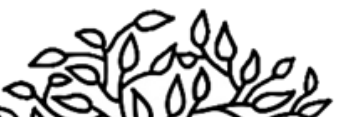


Arti Penting Pembelajaran Kaligrafi Arab untuk Menumbuhkan...

2. Mengembangkan kemampuan intelektual, imajinatif, ekspresif, kepekaan rasa estetik, kreatif, ketrampilan dalam menghargai terhadap hasil karya seni.

3. Secara estetis, kaligrafi memiliki unsur keindahan, hias dan plastisitas bentuk serta kekayaan ragam aksesoris dan iluminasinya yang menumbuhakan rasa estetika yang mendalam.

4. Kejelasan tulisan dan keindahan kaligrafi memudahkan informasi dan komunikasi baik di kalangan guru meupun peserta didik.

Dalam perkembangan kurikulum saat ini metode yang dapat dijadikan pendekatannya adalah pendekatan tematik, yakni pendekatan yang lebih menekankan pada keterlibatan siswa dalam proses belajar secara aktif dalam proses pembelajaran, sehingga siswa dapat memperoleh informasi langsung dan terlatih untuk dapat memiliki sendiri berbagai pengetahuan yang dipelajarinya.

Penggunaan kaligrafi Arab sebagai salah satu Seni Islam yang memiliki disiplin ilmu yang bisa digunakan sebagai media pembelajaran tematik untuk mata pelajaran agama di sekolah maupun madrasah (Akidah Akhlak, al-Qur'an Hadits, Fikih, maupun SKI) mampu memberikan sentuhan seni tersendiri sehingga seakan bahwa ragam pelajaran yang disuguhkan dengan kaligrafi adalah satu. Model ini ditujukan agar siswa yang baru memulai mengenal pelajaran agama memiliki rasa senang dan suka belajar merasa tidak terlalu banyak dibebani oleh banyaknya mata pelajaran agama yang disuguhkan.

Adapun praktik pembelajaran pendidikan agama Islam dengan media kaligrafi sebagai berikut:

1. Menentukan tema, hal ini dimaksudkan agar dalam penyampaian materi atau bahan ajar tidak keluar dari kurikulum mata pelajaran yang telah ditentukan.

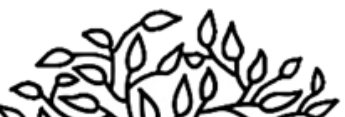


2. Mencari Ayat Al Quran, Hadits ataupun Mahfuzhat/Kata Hikmah yang sesuai dengan tema pelajaran untuk kemudian diajarkan melalui anak menulis dan berkreasi kaligrafi dengan materi tersebut. Pada tahapan inilah anak merasa bahwa beban pelajaran tidak seberat jika beberapa mata pelajaran disodorkan sekaligus, sehingga anak akan menikmatinya sebagai awal atau gerbang informasi baru.

3. Penyampaian Materi, di saat anak-anak sedang asyik mengerjakan kaligrafi Al Qur'an atau Hadits baik menulis hanya dengan menggunakan pensil maupun adanya membuat kaligrafi untuk diwarnai, guru dapat menyampaikan arti kata-katanya atau mufradat, tata bahasanya, kaitannya dengan Aqidah dan Akhlaq, Fiqih maupun Sejarah Kebudayaan Islam yang berhubungan dengan materi tersebut.

4. Koreksi dan Penilaian, setelah guru selesai menyampaikan semua materi, guru dapat memberi waktu bertanya seputar materi dan dapat pula sambil berkeliling melihat siswa yang sudah selesai untuk diberi nilai. Hal ini dapat memberi motivasi penting serta support bagi anak untuk segera menyelesaikan tugas menulis atau berkaligrafi.

Sedangkan langkah-langkahnya dalam pelaksanaan pembelajaran di antaranya dapat menampilkan; Pendahuluan, Menulis ungkapan di papan tulis, kemudian di baca, diuraikan artinya dan dijelaskan kandungan pikiran, isi kisah atau peristiwanya yang menarik sekitar tema pelajaran.

Orientasi, Memaparkan tema pelajaran, pemilahan hrufhuruf dan menerangkan bagian-bagiannya. Kemudian mengarahkan perhatian kepada sarana dengan praktek pemecahan, perbandingan, dan pengawasannya bentuk huruf secara cermat.

Selanjutnya tahap latihan, Menyampaikan beberapa pertanyaan umum sekitar masalah yang sudah diarahkan untuk

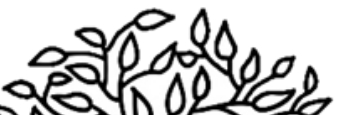


memperkukuh pemahaman tema, dan dalam waktu bersamaan mengkonsolidasikannya dalam ingatan. Tugas ini dilakukan tidak lebih dari 10 menit pelajaran. Setelah itu murid mengerjakan latihan, sementara guru berkeliling diantara mereka, sambil menarik perhatian murid kepada kesalahan-kesalaan umum di papan tulis.

Koreksi, Guru mengoreksi tulisan setiap murid dan membetulkan tugas yang lalu. Usai koreksi, murid menulis ulang dan guru membeikan pegarahan sekali lagi, kemudian memberi mereka Petunjuk pelajaran berikutnya sebelum meninggalkan pelajaran. Hasil PR dikoreksi pada pelajaran berikutnya.

\section{Kaligrafi dalam Pembelajaran Bahasa Arab dan Praktiknya}

Seperti yang kita ketahui bahwa fungsi dan isi mata pelajaran bahasa Arab; mata pelajaran ini berfungsi memberikan kemampuan dan keterampilan dasar kepada peserta didik untuk menunjang pengetahuan, pemahaman dan penghayatan terhadap syari'at islam, pengembangan ilmu pengetahuan, dan meningkatkan hubungan antar bangsa, serta pelajaran ini diarahkan memberikan kemampuan dan keterampilan dasar peserta didik, menggunakan bahasa Arab secara benar yang meliputi mendengar, berbicara, membaca, dan menulis serta menjadi bekal untuk jenjang pendidikan berikutnya.

Selama ini lembaga pendidikan yang mengajarkan bahasa Arab sebagai salah satu studinya telah menerapkan beberapa model dan bentuk pengajaran yang cukup kreatif. Namun bila ditelusuri lebih lanjut dalam banayak pelaksanaan pembelajaran bahasa Arab, sedikit yang menggunakan peran kaligrafi dalam pengayaan dasar bahasa. Hal tersebut dapat kita temukan dalam beberapa buku materi bahasa Arab di lingkungan sekolah. Dan agaknya ini tidak sesuai dengan beberapa buku materi yang diterbitkan langsung dari timur tengah.

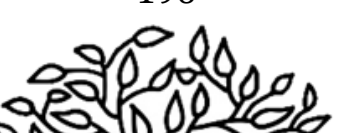


Selain dalam ketiadaan materi kaligrafi dalam buku materi bahasa Arab, perhatian lembaga pendidikan yang mengajarkan bahasa Arab juga masih sangat jarang yang memperhatikan upaya awal bagaimana memberi dasar kepada anak didik dengan aspek kemudahan dan penyenangan terhadap mata pelajaran, bukannya langsung dibebani dengan materi yang terkadang sama sekali tidak diketahui sebelumnya.

Bukan hanya itu saja, para pengajar bahasa Arab pun masih banyak beranggapan bahwa kaligrafi hanyalah sebagai seni tulismenulis saja, terlebih adanya perlombaan khusus kaligrafi maupun munculnya banyak karya seni lukis kaligrafi- sehingga ketika seorang tidak dapat menulis dengan baik bukanlah penghambat dalam mempelajari bahasa Arab. Anggapan inilah menurut penulis, adalah salah satu kendala dalam kelancaran pelaksanaan pembelajaran bahasa Arab.

Dapat kita lihat bahwa beberapa lembaga pendidikan bahasa Arab yang juga mengajarkan kaligrafi, baik bergabung dengan materi bahasa Arab maupun terpisah menjadi mata pelajaran tersendiri, maka kompetensi lulusannya pun akan jauh berbeda, terutama dalam penguasaan keterampilan menulis $-A t$ Ta'bîr Al-Kitâbiy-.

Dalam kaitannya dengan bahasa Arab khususnya dalam pembelajaran bahasa Arab, Menurut 'Abdul 'Alîm Ibrahîm bahwa kaligrafi (khath) memiliki kedudukan dalam pembelajaran bahasa Arab -bila diklasifikasi-diantaranya :

1. Kaligrafi juga memiliki peranan penting dalam mensukseskan keberhasilan pembelajaran bahasa tersebut hingga bagaimana keahlian kaligrafi dapat berkembang sesuai dengan perkembangan keilmuan.

2. Terlebih bila ditelusuri, pelajaran kaligrafi memang memiliki segi-segi yang dapat menumbuhkan upaya ketepatan bakat nalar ataupun rasa seseorang dalam mencari ilmu, diantaranya; sikap perhatian, ketelitian pembacaan

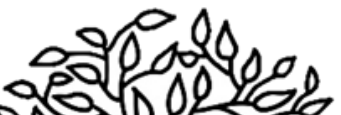


Arti Penting Pembelajaran Kaligrafi Arab untuk Menumbuhkan...

(mulâhazhah), serta melatih penggalian mana yang benar dalam sebuah pertimbangan maupun hukum.

3. Kaligrafi juga akan meghantarkan siswa pada pembiasaan baik, seperti; sikap teratur, ketelitian dan kebersihan. Selain itu, kaligrafi juga mempengaruhi pandangan mereka dalam bersaing sehat- dan paling tidak- akan membawa mereka dalam kebiasaan untuk berhati-hati, bersabar, dan mutsâbarah.

4. Kaligrafi merupakan salah satu media pembelajaran bahasa arab terutama terkait dengan ungkapan (ta'bîr) bidang tulisan, misalnya seperti bahwa tulisan yang baik dan jelas itu akan mempermudah proses penyampaian materi, memperjelas kebenaran yang diangkat dari pemikiran seorang penulis dalam sebuah ungkapan yang lebih memudahkan pembaca untuk memahaminya, sebaliknya tulisan yang acak-acakan dan jelek akan mengaburkan hasil pikiran yang ada dalam tulisan. Hal itu oleh kebanyakan orang kurang mendapat perhatian yang lebih, bahkan terkadang cenderung menyepelekan tentang cara dan arti pentingnya bidang tersebut, sehingga ketika dalam menyusun, sebuah tulisan malah tidak menarik untuk dibaca, lebih-lebih penyusunannya disertai dengan gaya tulisan yang tidak tertata rapi sehingga pembaca tidak bisa mendapatkan isi secara detail.

'Abdul 'Alîm juga memaparkan hal terkait dengan tujuan dari pembelajaran kaligrafi yaitu dimaksudkan agar anak didik terbiasa menulis cepat dan baik, sehingga hasil tulisannya teratur, dapat dibaca, serta memiliki daya tarik estetis. Menulis cepat disini merupakan bagian dari pengajaran bagaimana menulis yang teratur dan terkontrol. Sedangkan hasil yang jelas merupakan bentuk dari ketuntasan siswa dalam menulis atau menggoreskan huruf, tidak kurang dan tidak lebih. Dan nilai

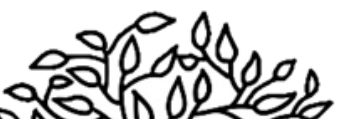


estetisnya merupakan sebagai perwujudan bagaimana hurufhuruf tersebut memiliki sifat-sifat tertentu, misalnya; penempatan persambungan hurufnya, pengaturan jarak tiap huruf yang teratur dan konsisten, serta pembentukan hurufhurufnya yang konsisten pula

Adapun dalam pembelajaran kaligrafi untuk anak, penulis membatasi pembahasan khat atau kaligrafi pada jenis khat Naskhi. Sebab jenis ini sejak ditemukannya aturan atau kaidah penulisan huruf Arab, jenis ini merupakan satu-satunya jenis yang sederhana, mudah dibaca dan dapat menjadi dasar dalam wawasan tulisan arab dibanding jenis lain serta dipakai untuk pembelajaran qira'ah. Sedangkan hubungannya dengan bahasa Arab adalah dalam kemahiran menulis (kitâbah) pada bahasa Arab tingkat dasar atau level mubtadi în. Atau secara rinci sebagai berikut :

1. Dalam pembahasan mengenai kaligrafi khat Naskhi adalah ditekankan pada kemampuan dalam belajar kaligrafi yang berorientasi pada penyaluran perasaan estetis dan berkesenian melalui pengalaman berekspresi baik tulisan maupun bentuk penerapannya dalam imla' disesuaikan dengan jenjang pendidikan. Dan bukan pada keahlian dalam berekspresi seni hingga dalam penerapan karya lukis kaligrafi. Adapun kemampuan tersebut secara terperinci meliputi:

a. Mampu menulis dan mengetahui cara pembentukan huruf Hijaiyyah yang benar baik di awal, tengah dan akhir

b. Memahami, menerapkan penulisan kaligrafi dalam persambungan huruf yang standar baik kata bahasa Arab, Mahfuzhat, ayat Al-Qur'an dan Hadits.

2. Sedangkan terkait dalam bahasa Arab dasar adalah mengacu pada bahasa Arab tingkat dasar atau level mubtadi în dengan pembahasan tentang pembelajaran at-ta'bîr al-kitâbiy yakni

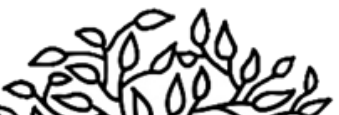


| Arti Penting Pembelajaran Kaligrafi Arab untuk Menumbuhkan...

penguasaan pembelajar dalam bidang tulisan dalam bentukbentuk hurufnya baik tunggal (mufradah) maupun persambungan huruf (tarkîbiyyah) hingga susunan yang di dalamnya meliputi terapan "qawâ'id al-imlâ" (kaidahkaidah penulisan Imla' bahasa Arab). Biasanya materi atau pelajaran imla' berisi mengenai karakteristik tulisan Arab yang berbeda dengan tulisan lain. Selain itu pembahasan penelitian ini bukan mengarah pada keahlian menulis karangan (insyâ') bahasa Arab atau dalam lingkup kitâbah alinsyâ'.

Adapun tahapan-tahapan pembelajaran kaligrafi berkaitan dengan bahasa Arab untuk anak, yaitu :

1. Kelas A (MI) Ibtida'iy :

- Anak belum cukup umur untuk menangkap materi kaidah menulis

- Anak hanya menulis huruf dan kata atau dalam kalimat semampunya bahkan bisa dibuat bermain dan menyenangkan

2. Kelas B (MI) Lanjutan :

- Sudah memaparkan kaidah menulis yang baik dengan jenis khat Naskhi

- $\quad$ Melatih, menilai, dan mengevaluasi hasil karya anak

- diselingi dengan lagu-lagu, cerita, atau bacaan yang mendukung

Hal-hal yang perlu diperhatikan dalam pembelajaran kaligrafi sebagaimana pengalaman penulis selama di MI adalah sebagai berikut:

1. menentukan tulisan dengan tema yang akrab

2. mengarahkan posisi yang tepat dalam menulis

3. jangan memberi penilaian yang terlalu membebani siswa, agar tidak menjadi malas dan bosan

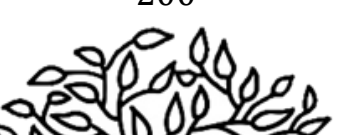


4. pesan untuk berlatih rapi, bersih, dan merawat alat-alat tulisnya dengan baik

5. membuat kurikulum, silabus dan RPP

6. meninggalkan catatan-catatan penting dalam hasil pekerjaan
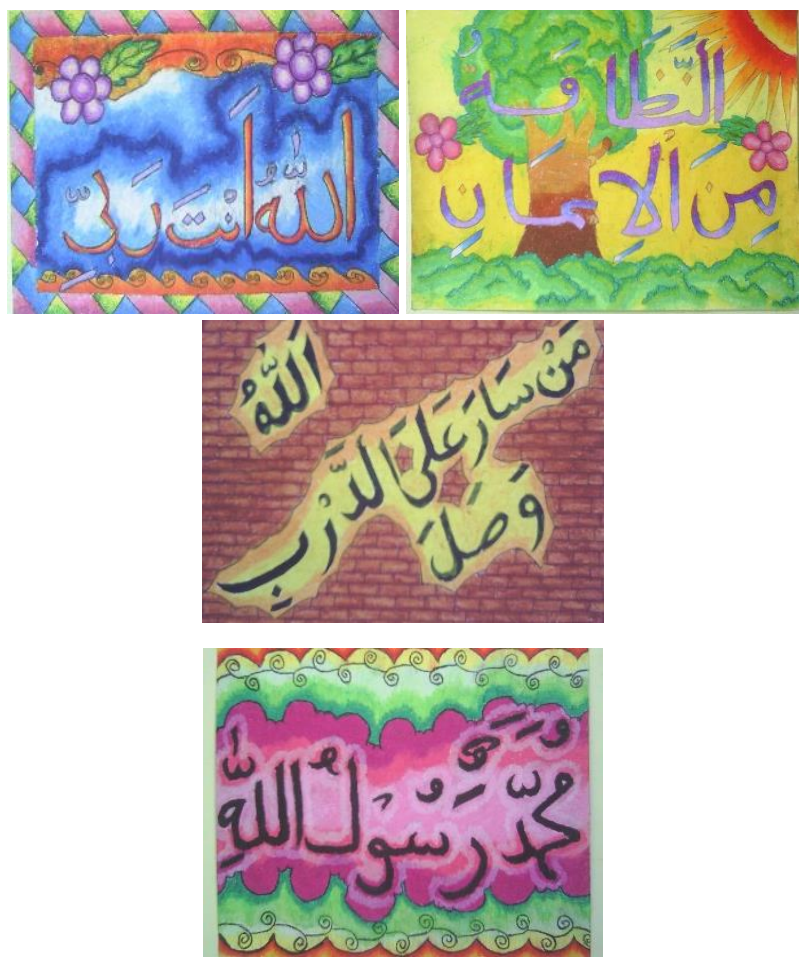

Gambar1. Karya-karya kaligrafi Anak MI/SDIT Sultan Agung tahun 2010 
Arti Penting Pembelajaran Kaligrafi Arab untuk Menumbuhkan...

\section{Daftar Pustaka}

'Abd al-'Alîm Ibrâhîm. al-Muwajjih al-Fanny, li Mudarrisî alLughah al-'Arabiyyah. Kairo: Dâr al-Ma'ârif, 1961. cet. Ke-IX.

Achsan, M. Midzar. Kaligrafi Hiasan Mushaf al-Qur'an. Gresik: alQalam, 2005.

Afifi, Faizi Salim. Cara Mengajar Kaligrafi Pedoman Guru. Jakarta: Darul Ulum Press, 2002.

Bagian Data dan Informasi Pendidikan Direktorat Jenderal Kelembagaan Agama Islam, Profil Madrasah Ibtidaiyah Jakarta: Depag RI, 2005.

Dyah Maharani, Ida Ayu. Republic, diterjemahkan oleh Benjamin Jowett. Denpasar: Fakultas Seni Rupa, 2012.

Habib, Mustopo. Ilmu Budaya Dasa. Surabaya: Usaha Nasional, 1983.

Israr, Sejarah Kesenian Islam Jilid 2. Jakarta: Bulan Bintang, 1978.

Khoiri, Ilham. Al-Qur'an dan Kaligrafi Arab. Jakarta: Logos Wawancara Ilmu, 1999.

Koesuma, Doni "Peran Pendidikan Karakter Dalam Melengkapi Kepribadian. (http://www.pendidikan karakter. com, diakses Selasa, 08 Oktober 2013).

Kursini, Siti. Keterampilan Dasar Mengajar (PPL) Berorientasi pada KBK. Fakultas Tarbiyah UIN Malang, 2006.

M. Hasan Syahâtah, Ta'lîm al-Lughah baina an-Nazhariyyah wa ath-Thathbîq. Kairo: Dar al-Mishriyyah al-Lubnâniyyah, 1994.

Munir, Misbahul. Mengenal Kaidah Kaligrafi al-Qur'an dilengkapi dengan 313 Contoh dan Ornamen Islami. Semarang: Binawan, 2004.

Sirojuddin, Didin. Asah Asuh Huruf Kaligrafi Islam. Jakarta: Darul Ulum Press, 2006.

Tafsir, Ahmad. Filsafat Umum. Bandung: Remaja Rosdakarya, 2004.

Tim 14 ASSKAR, Kaidah Penulisan dan Karya-karya Master Kaligrafi. Bojonegoro ASSKAR Pon. Pes. At-Tanwir, 2002.

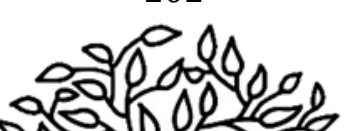


Nurul Huda, S.S., M.Pd.I. | 


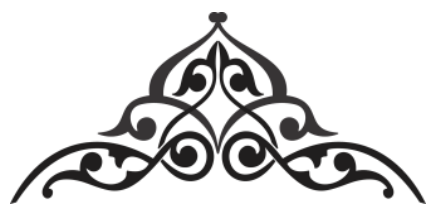

\title{
PEMBELAJARAN MATEMATIKA BERBASIS PROYEK DALAM MENINGKATKAN AKTIVITAS BELAJAR DI TENGAH PANDEMI COVID-19
}

\author{
Siti Rodi'ah, S.Pd.I ${ }^{2}$ \\ PRIMAGAMA Durenan
}

"Masa pandemi inilah merupakan momentum yang baik bagi guru untuk mencoba mengeksplorasi kompetensi dalam menciptakan strategi pembelajaran matematika yang mengarah pada keaktifan siswa"

Dandemi covid-19 telah melanda negeri ini. Seakan belum Padahal pandemi covid-19 telah berlangsung selama empat bulan. Tetapi, setiap hari berita di media selalu menayangkan peningkatan jumlah pasien yang terinfeksi covid-19. Hal ini dimungkinkan akibat berlakunya new normal . Seakan negeri ini telah terbebas dari covid-19. Bisa dilihat dengan adanya lokasilokasi yang mulai dipenuhi oleh lautan manusia. Aturan physical distancing mulai ditinggalkan. Walaupun banyak diantara mereka yang menggunakan masker dengan berbagai tujuan. Masa transisi inilah yang harus diwaspadai oleh masyarakat Indonesia untuk tetap menjaga diri dari penularan covid-19. Tentunya aktifitas fisik, aturan physical distancing, dan

2 Siti Rodi'ah lahir di Tulungagung pada tanggal 18 Jưni 1991, penulis merupakan salah satu tentor pada bidang matematika di PRIMAGAMA Durenan, penulis mendapat gelar sarjana di IAIN Tulungagung (2014), penulis saat ini sedang menyelesaikan pendidikan Magister PGMI di Pascasarjana IAIN Tulungagung. 
pendisiplinan diri menjadi kunci untuk menghambat lonjakan kasus terinfeksi covid-19 di negeri ini.

Banyak sektor yang dirugikan dari pandemi covid-19. Salah satunya adalah pada sektor pendidikan. Ya, tanpa disadari dunia pendidikan mulai menunjukkan goncangan. Karena proses pembelajaran yang harus dilalui secara daring. Tentunya berbagai permasalahan mulai bermunculan satu persatu. Mulai dari ketidaksiapan guru dalam memanfaatkan IT, selanjutnya ketidaksiapan walimurid dalam memfasilitasi anak-anaknya untuk mengikuti pembelajaran online, serta konsep pembelajaran yang ditawarkan oleh guru di masa covid-19. Hal ini berakibat tujuan pembelajaran yang telah dirancang sebelumnya, menjadi tidak tercapai. Padahal untuk menguasai suatu kompetensi dasar, maka peserta didik harus mencapai tujuan pembelajaran secara baik.

Tulisan ini terinspirasi ketika penulis melakukan suatu penelitian dan pengembangan bahan ajar. Melalui riset awal, bahwasannya dijumpai pembelajaran daring yang dilakukan oleh mayoritas guru belum menunjukkan suatu inovasi dalam memberikan pembelajaran yang mengoptimalkan kemampuan peserta didik. Baik secara psikomotorik, afektif dan kognitif. Mayoritas guru hanya mengirimkan pesan whatsap berupa tugas-tugas yang harus dikerjakan oleh siswa. Dimana tugastugas tersebut diambil dari LKS, buku paket, ataupun soal-soal latihan yang dikirim oleh guru melalui pesan whatsap. Hal ini mengindikasikan terjadinya penurunan motivasi belajar siswa. Akibatnya anak menjadi malas untuk belajar. Aktivitas belajar menjadi tergantikan dengan kegiatan yang lebih menarik yaitu bermain, atau melihat televisi.

Salah satu pelajaran yang wajib dipelajari oleh peserta didik adalah mata pelajaran matematika. Dimana mata pelajaran tersebut diajarkan disemua jenjang pendidikan. Hal ini mengindikasikan bahwa matematika adalah salah satu pelajaran

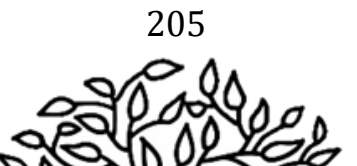


yang sangat penting untuk dikuasai oleh peserta didik di semua jenjang pendidikan. Karena matematika merupakan suatu media untuk mengembangkan keterampilan berpikir (Rezan, 2020;18). Tetapi mayoritas peserta didik tidak senang dengan pelajaran matematika. Karakteristik yang bersifat abstrak, menjadikan pelajaran matematika sulit untuk dipahami siswa (Sutarto, 2018; 4). Keadaan ini perlu dijadikan perhatian oleh semua pihak yaitu siswa sebagai pembelajar yang aktif, guru sebagai pendidik, kepala sekolah sebagai pemangku kebijakan, serta berbagai elemen yang memiliki kontribusi pada dunia pendidikan.

Saya menjumpai bahwa praktek pembelajaran matematika masih berorientasi pada penyelesaian soal-soal latihan. Menurut beberapa guru yang menjadi objek penelitian saya, bahwa pemberian drill bagi siswa sangat efektif untuk menunjang kemampuan kompetensi dasar. Padahal tujuan pembelajaran matematika adalah membatu siswa dalam memahami hubungan antara matematika dan dunia nyata (Sumeyra, 2019;183). Sedangkan arah kurikulum 2013 adalah mengembangkan keterampilan menalar, mengkomunikasikan, dan mencipta terhadap peserta didik (Yani, 2014; 30). Melalui praktek pembelajaran yang seperti itu, tidaklah cukup untuk memfasilitasi pengembangan keterampilan berpikir pada peserta didik. Disamping itu, arah pembelajaran tersebut hanya berorientasi pada penghafalan bentuk algoritma penyelesaian. Dimana siswa harus menghafal rumus dan definisi terlebih dahulu. Serta melihat contoh penyelesaian soal matematika berupa alur dalam menyelesaikan permasalahan matematika. Melalui modal rumus dan berbagai contoh penyelesaian matematika yang telah dihafal, siswa dapat menyelesaikan soalsoal tersebut dengan mudah. Tentunya hal ini sangat berseberangan dengan tujuan pembelajaran matematika dan orientasi kurikulum 2013.

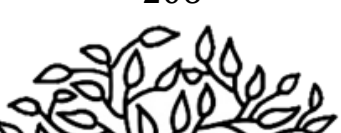


Pembelajaran di masa pandemi covid-19 mengarah pada pembelajaran daring, termasuk pelajaran matematika. Konsep pembelajaran matematika yang dilakukan oleh guru adalah serupa dengan mata pelajaran yang lain yaitu penugasan kepada siswa melalui via whatsap. Berupa pengkajian materi secara mandiri, serta soal-soal yang harus dikerjakan oleh siswa. Rutinitas kegiatan belajar siswa hanya diisi oleh kegiatan membaca dan mengerjakan soal. Yaitu lebih berorientasi pada aspek kognitif. Karena terbatas akan kompetensi yang dimiliki oleh guru. Selain itu, guru belum menunjukkan inovasi pembelajaran. Seperti yang kita ketahui dalam kenyataan di lapangan atau berbagai artikel, bahwa guru menggunakan metode ceramah dalam proses pembelajaran matematika. Mungkin metode tersebut dirasa sangat efektif dalam mengajarkan matematika pada peserta didik. Padahal banyak sekali informasi atau pengetahuan yang dapat diakses dengan mudah di era big data ini, untuk menambah kompetensi dan pengetahuannya.

Inovasi pembelajaran matematika sangat diperlukan dalam menunjang proses pembelajaran matematika yang lebih menarik. Apalagi di masa pandemi ini, aktivitas kegiatan siswa telah dibatasai oleh keadaan. Walaupun arah new normal mulai menampakkan wajahnya. Tetapi banyak orang tua yang masih bersikap prefectif dalam menjaga anak-anaknya. Tentunya keadaan seperti ini menjadi peluang bagi guru dalam memperbaiki pembelajarannya maupun menciptakan inovasi dalam memfasilitasi peserta didik untuk belajar matematika secara menarik dan tidak penuh beban. Sekiranya aktivitias belajar matematika yang terpaku dalam menyelesaikan soal-soal latihan, menjadikan beban kognitif yang sangat berat bagi siswa. Hal ini juga memberikan peluang bagi mereka untuk memilih jalan pintas, yaitu melalui bantuan google. Dengan sebuah aplikasi tersebut, mereka dapat memperoleh berbagai informasi,

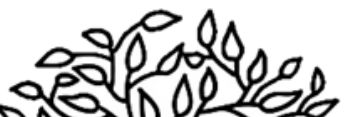




\section{* | Pembelajaran Matematika Berbasis Proyek dalam...}

termasuk cara menyelesaikan soal-soal matematika yang ditugaskan oleh guru. Tentunya hal ini sangat bertentangan dengan tujuan pembelajaran matematika maupun tujuan dari Kurikulum 2013. Dimana saat ini, di Indonesia menggunakan Kurikulum 2013 untuk dijadikan pedoman aktivitas pendidikan.

Salah satu metode pembelajaran yang menarik yang dapat mengisi aktifitas sehari-hari di rumah adalah metode pembelajaran berbasis proyek. Secara historis, metode pembelajaran berbasis proyek ini berakar dari tradisi pragmatis John Dewey, yaitu learning by doing (Warsono, 2014; 145). Dimana metode tersebut dapat meningkatkan keterlibatan siswa secara aktif dalam memahami materi (Tatag, 2018;198). Yaitu melalui tugas proyek sebagai titik awal suatu pembelajaran yang menyajikan langkah-langkah sintaks yang harus dikerjakan oleh siswa untuk mencapai tujuan pembelajaran. Melalui aktivitas proyek yang telah dirancang oleh guru atau dirancang sendiri oleh siswa. Tentunya dalam melakukan aktivitas proyek, seorang siswa tidak hanya mengandalkan aspek kognitif saja, melainkan aspek psikomotorik dan afektif. Selain itu, seorang siswa akan merasa bebas dalam menyampaikan idenya yang didasarkan pada hasil temuannya. Siswa tidak terlalu merasa takut akan pengambilan keputusannya, karena didasarkan pada hasil temuannya. Tidak seperti situasi dalam menjawab soal-soal latihan. Dimana siswa akan terkungkung dalam situasi "benar dan salah".

Berdasarkan observasi penelitian saya, yaitu pengembangan LKS Matematika berdasarkan metode Project Based Learning atau dikenal dengan pembelajaran berbasis proyek, saya melihat proses belajar siswa sangat aktif. Yaitu berdasarkan hasil dokumentasi dari walimurid yang dikirmkan ke guru kelas, dan guru tersebut mengirimkan ke saya. Mulai dari proses memotong kertas, memberikan garis, serta menelaah hasil eksperimen peserta didik. dan Selanjutnya menulis hasil

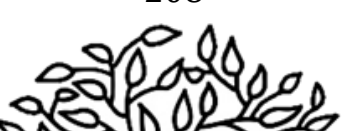


temuannya di lembaran. Dimana siswa senantiasa menghubungkan situasi nyata melalui tugas proyek dengan konsep matematika. Tentunya pembelajaran yang demikian tidak membosankan bagi siswa. Siswa tidak selalu disuapi dengan angka-angka dan simbol-simbol matematika. Tetapi siswa difasilitasi aktivitas belajar secara nyata dan bukan melalui proses membayangkan saja. Bahkan output dari pembelajaran berbasis proyek ini adalah siswa dapat mengkonstruksi pengetahuannya secara mandiri. Definisi dan rumus akan diperolehnya melalui kegiatan proyek, bukan dari menghafal atau hanya sekedar membaca informasi.

Tentunya di masa pandemi ini, guru harus membuat terobosan dalam melakukan proses pembelajaran matematika secara daring. Jika seorang guru hanya mengandalkan peugasan siswa melalui buku teks yang tersedia di sekolahan atau hanya mengandalkan LKS yang diterbitkan dari pihak penerbit, tentunya akan terkalahkan dengan kecanggihan teknologi. Dimana siswa dapat mengakses berbagai informasi di google. Dikhawatirkan siswa menjadi tergantung dengan teknologi, bukan dari potensi yang mereka miliki. Padahal setiap siswa dianugerahi potensi yang luar biasa oleh Allah swt. Perlu adanya stimulus dalam mengeksplorasi potensi peserta didik. salah satunya adalah melalui aktivitas belajar secara eksperimen. Melalui aktivitas belajar secara eksperimen, tentunya dapat meminimalisir ketergantungan siswa terhadap penggunaan teknologi. Dimana ketergantungan akan penggunaan teknologi, lambat laun akan menjerumuskan siswa kepada budaya instan, yaitu dalam ranah belajar.

Masa pandemi covid-19 ini merupakan momentum yang baik untuk mencoba memperkenalkan pembelajaran matematika berbasis proyek. Saya yakin hal ini tidaklah mudah dilakukan oleh siswa. Perlu ada adaptasi dari mereka, karena dalam memorinya belum ada informasi mengenai aktivitas

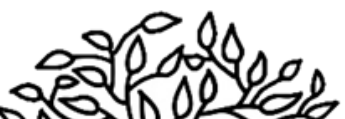




\section{| Pembelajaran Matematika Berbasis Proyek dalam...}

belajar matematika berbasis proyek. Dimana pada masa-masa belajar di sekolah atau di rumah, siswa terbiasa mendengarkan informasi dari guru, membaca informasi dari buku dan mengerjakan soal-soal latihan. Melalui aktivitas belajar berbasis proyek dapat meningkatkan aktivitas belajar. Serta siswa senantiasa memberdayakan kemampuannya dalam melakukan pemecahan masalah, berpikir kritis, dan berani dalam mengemukakan idenya. Pada akhirnya siswa memahami bahwa matematika merupakan bagian dari kehidupan sehari-hari. Matematika adalah alat untuk memecahkan permasalahan sehari-hari. Hal ini menjadikan siswa lebih dekat dengan matematika, sehingga siswa akan senang belajar matematika.

Semoga tulisan pendek ini memberikan inspirasi terhadap pengajar dan saya sendiri sebagai mahasiswa PGMI. Terutama dalam menyajikan pembelajaran matematika kepada siswa. Perlu kita ketahui bahwasannya pembelajaran matematika dipengaruhi oleh filsaafat konstruktivisme yaitu pengetahuan dibangun oleh siswa sendiri. Tentunya dalam mendesaian pembelajaran matematika perlu memperhatikan strategi dalam meciptakan keaktifan siswa dalam membangun konsep matematika. Ditinjau dari perkembangan teknologi yang begitu pesat, diperlukan pengembangan kompetensi guru dalam mengubah metode yang telah mengakar dalam dirinya yaitu ceramah atau hanya penugasan. Masa pandemi inilah merupakan momentum yang baik bagi guru untuk mencoba mengeksplorasi kompetensi dalam menciptakan strategi pembelajaran matematika yang mengarah pada keaktifan siswa. Karena di masa ini, guru memiliki banyak waktu luang. Dimana waktu luang tersebut dapat dimanfaatkan ke arah yang positif. Salah satunya adalah mengembangkan kompetensinya.

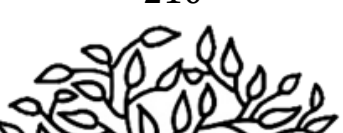




\section{DAFTAR PUSTAKA}

Coskun Dogan Sumeyra, Emre EV Cimen. 2019. "Pre-Service Elementary Teachers' Difficulties In Solving Realistic Devision Problems," dalam Acta Didactica Napocensia, Vol. 12, Number. DOI:10.24193/and.12.2.14

Hadi Sutarto. 2018. Pendidikan Matematika Realistik: Teori, Pengembangan, dan Implementasinya. (Depok: Raja Grafindo Persada)

Siswono Eko Yuli Tatag, Hartono Sugi, Kohar Wachid Ahmad. 2018. "Effectiveness of Project Based Learning in Statistics for Lower Secondary School," dalam Eurasian Journal of Education Research. DOI: 10.14689/ejer.2018.75.11

Warsono.2014. Pembelajaran Aktif . Bandung: Remaja Rosdakarya

Yani Ahmad. 2014. Mindest Kurikulum 2013. (Bandung: Alfabeta) Yilmaz Rezan, "Prospective Mathematics Teachers Cognitive Competences On Realistic Mathematics Education," dalam Journal on Mathematics Education, Vol. 11, No. 1, January 2020,

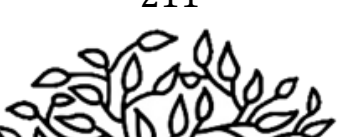




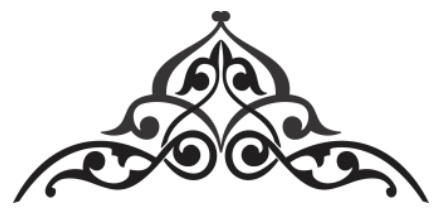

PRODUKTIF BERKARYA DI ERA PANDEMI

\author{
Nurul Nitasari, M. Pd. ${ }^{2}$ \\ MTs. N 1 Kudus
}

"Pendidik diharapkan dapat mengurai hikmah di balik pandemi ini dengan terus produktif berkarya, misalnya melalui penyusunan buku, artikel dan media pembelajaran"

$\mathrm{P}$ enyebaran Covid-19 mulai terjadi di penghujung tahun 2019 dan masuk ke Indonesia di awal tahun 2020 telah membuat banyak pihak terdampak pandemi. Banyak sekali masyarakat yang terkena dampak dari wabah ini, baik itu langsung maupun tidak langsung. Dampak tersebut tersebar di berbagai sektor, tidak terkecuali di sektor pendidikan.

Di sektor pendidikan, semua stakeholder yang terlibat dituntut untuk dapat menyesuaikan keadaan, baik itu pemerintah, pihak sekolah, dan masyarakat. Pemerintah sudah membuat ketentuan mengenai aturan pelaksanaan kegiatan belajar mengajar bagi peserta didik. Begitu juga pihak sekolah, mulai dari kepala sekolah, guru, peserta didik maupun bagian tata usaha harus menyesuaikan aturan yang telah ditetapkan

2 Nurul Nitasari lahir di Kudus, 25 Mei 1988, penulis merupakan Guru Bahasa Indonesia di MTs.N 1 Kudus. Penulis menyelesaikan gelar Sarjana Pendidikan di Universitas Negeri Semarang (2010), demikian pula gelar Magister Pendidikan diselesaikan di Universitas Negeri Semarang (2014). Penulis telah mengabdi di dunia pendidikan selama 10 tahun. 
oleh pemerintah. Selaras dengan itu, keterlibatan masyarakat mulai dari wali murid sampai warga sekitar sekolah sangat diharapkan dalam rangka mencapai kesepakatan bersama untuk satu tujuan.

Di era normal baru ini, banyak sekali kebijakan yang perlu dipatuhi dan dilaksanakan oleh seluruh lapisan masyarakat dengan tujuan meminimalkan dampak negatif dari pandemi ini. Terlebih di bidang pendidikan, guru dituntut untuk aktif dan kreatif dalam melaksanakan kegiatan belajar mengajar secara daring. Dengan demikian, melek teknologi dan mau terus belajar itu suatu keharusan.

Banyak sekali instansi pemerintah maupun swasta yang mengadakan webinar maupun workshop daring dalam rangka meningkatkan kemampuan guru. Hal tersebut bertujuan agar guru selalu produktif menciptakan sumber belajar, skenario pembelajaran, media, dan evaluasi pembelajaran yang sesuai dengan keadaan sekarang ini. Selain itu, banyak pula sayembara dan lomba-lomba yang diadakan dalam rangka menggali kreativitas dan produktivitas guru dan peserta didik.

Waktu luang bagi guru dan peserta didik di tengah pandemi Covid-19 ini harus dimanfaatkan dengan baik. Produktif berkarya adalah salah satu hal utama dalam rangka menjaga eksistensi diri di tengah pandemi. Dengan produktif berkarya, tentunya banyak sekali manfaat yang kita peroleh.

Aktif membaca dan update informasi adalah hal wajib yang harus dilakukan oleh seorang guru untuk meningkatkan produktivitas dalam berkarya. Selain update materi untuk disampaikan dalam pembelajaran, sebagai pendidik kita harus selalu belajar untuk meningkatkan kualitas keilmuan dan peningkatan jenjang karier. Banyak sekali sumber belajar yang dapat kita gali di era pandemi ini. Salah satunya yakni melalui webinar-webinar yang hampir setiap hari dilaksanakan oleh instansi negeri maupun swasta.

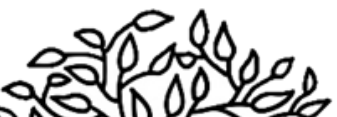


Melalui webinar, kita dapat menggali informasi dari narasumber yang qualified di bidangnya. Banyak sekali webinar dengan beragam topik yang dapat meningkatkan kualitas keilmuan kita, mulai dari pengenalan beragam software dan aplikasi yang mendukung pembelajaran sampai evaluasi pembelajaran yang relevan di era ini. Hal itu tentunya akan memacu kita untuk terus belajar secara mandiri setelah itu. Dengan bekal dan informasi yang sudah kita peroleh, kita dapat mengembangkan beragam produk dan karya yang tentunya dapat bermanfaat.

Berikut merupakan produk dan karya bidang pendidikan yang dapat kita kembangkan selama era pandemi covid-19 dan normal baru.

\section{Buku}

Dengan berkurangnya durasi mengajar selama masa normal baru ini, guru akan lebih banyak waktu untuk menulis buku. Banyak sekali pilihan genre buku yang dapat hasilkan, antara lain buku teks pelajaran, buku pengayaan, buku kumpulan karya sastra, dan buku tentang pengalaman kita selama menjadi seorang guru.

Kegiatan menulis ditandai oleh cara berpikir yang kompleks dan abstrak (Suryaman:2010). Melalui menulis buku, skill bidang kepenulisan kita akan terlatih dengan baik. Menulis buku memerlukan ketelitian, kesabaran, dan kedalaman materi yang memadai. Apalagi di tengah pandemi, isu mengenai covid-19 paling banyak diminati. Keadaan tersebut dapat kita manfaatkan untuk mendongkrak nilai ekonomis dari buku yang kita hasilkan.

\section{Artikel}

Artikel ilmiah dan artikel populer tentunya memiliki perbedaan. Penelitian yang pernah kita lakukan, misalnya PTK dapat kita jadikan sebuah artikel ilmiah untuk dimuat dalam

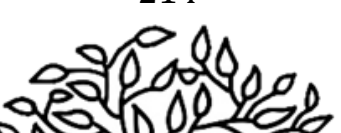


jurnal. Berbeda dengan artikel populer yang muara akhirnya adalah dimuat di majalah atau koran.

Melalui workshop atau pelatihan-pelatihan yang dilaksanakan akhir-akhir ini banyak sekali komunitas yang dibimbing langsung oleh para mentor. Dengan mentor yang sudah berpengalaman di bidang publikasi ilmiah dan populer tentunya dapat memberikan jalan dan arahan agar para peserta lebih mudah melakukan publikasi.

Di masa pandemi ini banyak pula lembaga-lembaga yang mengadakan kompetisi menulis artikel. Kompetisi tersebut tidak hanya bagi guru, tetapi banyak sekali yang sasarannya adalah peserta didik dengan berbagai tingkatan. Sasarannya mulai dari tingkatan dasar, menengah, dan perguruan tinggi.

\section{Media Pembelajaran}

Sebagai guru, pemanfaatan media dalam pembelajaran tentunya menjadi hal yang menyenangkan. Dengan media yang interaktif, peserta didik akan lebih memahami materi pelajaran. Dengan media yang menarik pula, peserta didik akan lebih bersemangat dalam belajar.

Ada berbagai macam media pelajaran yang dapat digunakan oleh guru ketika menyampaikan materi secara daring. Beberapa di antaranya yaitu powerpoint, film, video animasi dan lain sebagainya yang dapat dikemas secara menarik. Guru juga dapat memanfaatkan aplikasi yang disediakan secara gratis di playstore, seperti kinemaster, corel video studio, imovie, windows movie maker dan masih banyak lagi.

Sebagai pendidik, kita tidak akan tahu sampai kapan pandemi covid-19 akan berakhir. Oleh sebab itu, pendidik diharapkan dapat mengurai hikmah di balik pandemi ini dengan terus produktif berkarya. Dengan demikian, kebermanfaatan karya kita dapat dirasakan oleh semua pihak.

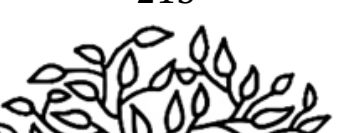




\section{DAFTAR PUSTAKA}

Suryaman, Maman. 2011. "Potensi Alam, Sosial, dan Budaya Lokal sebagai Bahan Penulisan Buku Nonteks Pelajaran". Pelatihan Penulisan Buku Nonteks Pelajaran. Provinsi Riau 20 s..d. 23

Juni 2011.http://staff.uny.ac.id/sites/default/files/pengabdian/ dr-maman-suryaman-mpd/lokal-riau-dlm-penulisan-buku2011.pdf 
Nurul Nitasari, M.Pd.| 


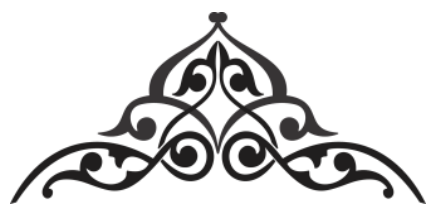

BERDAMAI DENGAN COVID-19;

MEMBIASAKAN DIRI DENGAN TATANAN

HIDUP DI ERA NORMAL BARU

\section{Diana Lutfiana Ulfa, M.Pd. ${ }^{2}$ \\ IAIN Tulungagung}

"Tatanan hidup di era normal baru (new normal) mau tidak mau harus tetap dijalankan sesuai dengan aturan"

$\mathrm{B}$ erdamai dengan virus. Rasanya masih sulit untuk menerima kata-kata itu. Seakan tidak mungkin untuk melakukan hal itu. Persis seperti reaksi netizen yang kaget ketika mengetahui presiden Joko Widodo menyatakan bahwa kita harus berdampingan hidup dengan Covid, dalam pernyataan resminya di Istana Merdeka, Jakarta, Jumat, 15 Mei 2020. Presiden Joko Widodo menampik jika hidup berdampingan dengan Covid-19 sama dengan menyerah melawan penyakit itu. Perlawanan terhadap Covid-19 tetap berlangsung dengan mengedepankan protokol kesehatan. Pemerintah akan mengatur agar kehidupan masyarakat berangsur-angsur dapat kembali berjalan normal.

2 Diana Lutfiana Ulfa lahir di Blitar, 28 Januari 1992, penulis meruß̊akan Dosen IAIN Tulungagung dalam bidang ilmu Pendidikan Dasar (PGMI), Lulusan Sarjana dan Magister PGMI di IAIN Tulungagung (2017). Bisa di hubungi di nomor WA 08563676201 atau diana.lutfiana@gmail.com 
Sebagaimana telah diketahui, virus ini tidak akan mungkin hilang dari muka bumi ini. Sebagaimana virus lain yang tetap ada, kemudian ditemukan vaksinnya. Lalu kita terbiasa dengan keberadaannya. Perilaku masyarakat pun akan berangsur pulih, yang awalnya takut keluar rumah, takut berinteraksi dengan orang lain. Perlahan mulai kembali seperti semula.

Kita harus tetap berkarya meski pandemi melanda. Kita harus tetap melakukan kegiatan meski tidak bisa sama persis seperti sebelumnya. Menuju era normal baru (new normal) kita harus bersiap untuk beradaptasi agar aktivitas tetap bisa berjalan lancar seperti sedia kala. Berkaitan dengan adanya normal baru ini, Kementerian Kesehatan (Kemenkes) menerbitkan Keputusan Menteri Kesehatan nomor HK.01.07/MENKES/328/2020 tentang Panduan Pencegahan dan Pengendalian COVID-19 di Tempat Kerja Perkantoran dan Industri dalam Mendukung Keberlangsungan Usaha pada Situasi Pandemi.

Normal baru yang sedang jadi trending topic merupakan tatanan baru yang memang perlu ada, sebab hingga kini belum ditemukan vaksin definitif dengan standar internasional untuk pengobatan virus corona. Para ahli masih bekerja keras untuk mengembangkan dan menemukan vaksin agar bisa segera digunakan untuk pengendalian pandemi Covid-19. Kemudian, apa saja yang perlu dipersiapkan untuk menyambut normal baru ini?

1. Kebijakan Manajemen dalam Pencegahan Penularan COVID19

a) Pihak manajemen agar senantiasa memantau dan memperbaharui perkembangan informasi tentang COVID-19 di wilayahnya. (Secara berkala dapat diakses di http://infeksiemerging.kemkes.go.id. dan kebijakan Pemerintah Daerah setempat).

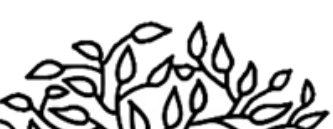


b) Pembentukan Tim Penanganan Covid-19 di tempat kerja yang terdiri dari Pimpinan, bagian kepegawaian, bagian K3 dan petugas Kesehatan yang diperkuat dengan Surat Keputusan dari Pimpinan Tempat Kerja.

c) Pimpinan atau pemberi kerja memberikan kebijakan dan prosedur untuk pekerja melaporkan setiap ada kasus dicurigai Covid-19 (gejala demam atau batuk/pilek/nyeri tenggorokan/sesak nafas) untuk dilakukan pemantauan oleh petugas kesehatan.

d) Tidak memperlakukan kasus positif sebagai suatu stigma.

e) Pengaturan bekerja dari rumah (work from home). Menentukan pekerja esensial yang perlu tetap bekerja/datang ke tempat kerja dan pekerja yang dapat melakukan pekerjaan dari rumah.

2. Jika ada pekerja esensial yang harus tetap bekerja selama PSBB berlangsung:

a) Di pintu masuk tempat kerja lakukan pengukuran suhu dengan menggunakan thermogun, dan sebelum masuk kerja terapkan Self Assessment Risiko Covid-19 untuk memastikan pekerja yang akan masuk kerja dalam kondisi tidak terjangkit Covid-19.

b) Pengaturan waktu kerja tidak terlalu panjang (lembur) yang akan mengakibatkan pekerja kekurangan waktu untuk beristirahat yang dapat menyebabkan penurunan sistem kekebalan/imunitas tubuh.

c) Untuk pekerja shift: Jika memungkinkan tiadakan shift 3 (waktu kerja yang dimulai pada malam hingga pagi hari). Bagi pekerja shift 3 atur agar yang bekerja terutama pekerja berusia kurang dari 50 tahun.

d) Mewajibkan pekerja menggunakan masker sejak perjalanan dari/ke rumah, dan selama di tempat kerja.

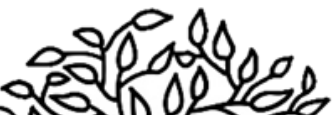


e) Mengatur asupan nutrisi makanan yang diberikan oleh tempat kerja, pilih buah-buahan yang banyak mengandung vitamin $\mathrm{C}$ seperti jeruk, jambu, dan sebagainya untuk membantu mempertahankan daya tahan tubuh. Jika memungkinkan pekerja dapat diberikan suplemen vitamin.

f) Memfasilitasi tempat kerja yang aman dan sehat.

3. Higiene dan sanitasi lingkungan kerja

a) Memastikan seluruh area kerja bersih dan higienis dengan melakukan pembersihan secara berkala menggunakan pembersih dan desinfektan yang sesuai (setiap 4 jam sekali). Terutama pegangan pintu dan tangga, tombol lift, peralatan kantor yang digunakan bersama, area dan fasilitas umum lainnya.

b) Menjaga kualitas udara tempat kerja dengan mengoptimalkan sirkulasi udara dan sinar matahari masuk ruangan kerja, pembersihan filter AC.

c) Menyediakan lebih banyak sarana cuci tangan (sabun dan air mengalir).

d) Physical Distancing dalam semua aktifitas kerja. Pengaturan jarak antar pekerja minimal 1 meter pada setiap aktifitas kerja (pengaturan meja kerja/workstation, pengaturan kursi saat di kantin, dll).

e) Mengkampanyekan Gerakan Masyarakat Hidup Sehat (GERMAS) melalui Pola Hidup Sehat dan Perilaku Hidup Bersih dan Sehat (PHBS) di tempat kerja sebagai berikut: Cuci Tangan Pakai Sabun (CTPS) Mendorong pekerja mencuci tangan saat tiba di tempat kerja, sebelum makan, setelah kontak dengan pelanggan/pertemuan dengan orang lain, setelah dari kamar mandi, setelah memegang benda yang kemungkinan terkontaminasi.

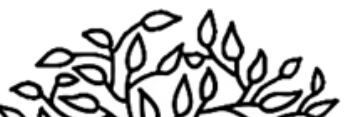


f) Etika batuk Membudayakan etika batuk (tutup mulut dan hidung dengan lengan atas bagian dalam) dan jika menggunakan tisu untuk menutup batuk dan pilek, buang tisu bekas ke tempat sampah yang tertutup dan cuci tangan dengan sabun dan air mengalir setelahnya

g) Hindari penggunaan alat pribadi secara bersama seperti alat sholat, alat makan, dan lain lain.

Penerapan panduan ini diharapkan dapat meminimalisir risiko dan dampak pandemi Covid-19 pada tempat kerja khususnya, perkantoran, industri, dan lingkungan hidup dimana terdapat potensi penularan akibat berkumpulnya banyak orang dalam satu lokasi. Kuncinya kita harus tetap ketat menjaga protokol kesehatan, tetap menjaga jarak, tetap mencuci tangan sehabis kegiatan, dan tetap pakai masker jika keluat rumah/bepergian.

Mungkin terdengar sulit dan ribet sekali, akan tetapi kalau hal tersebut sudah menjadi kebiasaan, normal baru akan sukses kita terapkan. Oleh karena itu, tugas pemerintah, dan umumnya pada tokoh masyarakat/agama secara sosiologis adalah menciptakan kenyamanan dan keamanan agar masyarakat tidak berada pada kekhawatiran ketakutan dan kepanikan yang berlebihan. Utamanya berita-berita dalam media sosial. Kalau kita menerima semua share berita yang ada tanpa tabayyun, kita sendiri yang akan pusing di buatnya. Ketika media tak terkendali, kitalah yang harus mengendalikan diri sendiri, dengan banyak menggali informasi serta menyaring berita yang masuk, apakah hoax atau benar adanya.

Kesimpulan yang dapat kita tarik dari tulisan di atas adalah bahwa virus corona atau covid-19 yang merebak berimplikasi pada pola kerja maupun pola hidup masyarakat Indonesia. Pola kerja yang sebelumnya dilakukan di kantor, sekarang bisa dilakukan di rumah masing-masing. Proses belajar mengajar yang biasanya dilakukan secara langsung dengan tatap muka di

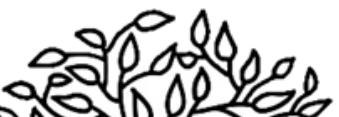


luar jaringan (luring) menjadi tanpa tatap muka dalam jaringan internet (daring). Virus Corona telah banyak mengubah kehidupan kita. Memaksa manusia untuk menciptakan inovasiinovasi baru yang mungkin tak pernah terpikir sebelumnya. Daripada kita dibuat pusing olehnya, alahngkah baiknya kita petik hikmah di balik adanya wabah. Menuju tatanan hidup di era normal baru (new normal) yang mau tidak mau akan tetap kita jalankan sesuai dengan aturan.

Tabik!

\section{Daftar Pustaka}

Artikel "Protokol New Normal Kemenkes untuk Cegah Penularan Corona COVID-19", https://tirto.id/fCRj

https://www.kemkes.go.id/article/view/20060200002/keluarg a-kunci-untuk-memasuki-era-new-normal.html www.covid19.go.id. 


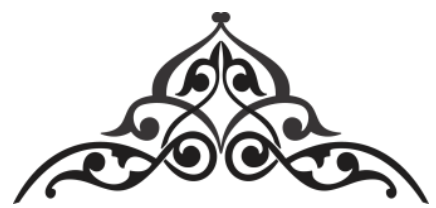

\title{
STRATEGI PENGELOLAAN ZAKAT FITRAH \\ PADA MASA PANDEMIC COVID-19
}

\author{
Dian Adi Perdana, S.Sos.I., M.M. ${ }^{2}$ \\ IAIN Sultan Amai Gorontalo
}

"Keberadaan financial technology telah membuka dan membawa cakrawala lembaga zakat untuk selalu memanfaatkan teknologi informasi dalam setiap proses dan praktik operasional untuk memberdayakan zakat sebagai potensi pembangunan ekonomi sosial di Indonesia dalam masa pandemic COVID-19"

Dandemik yang begitu dahsyat sedang mengguncang dunia
ini, dunia mengenalnya dengan nama Virus Corona atau Covid-19. Akhir tahun 2019, virus ini telah menyebar luas dengan diawali dari kota Wuhan, Provinsi Hubei, RRT ata Tiongkok, ke berbagai belahan dunia. Virus ini hadir dari mutasi virus sebelumnya yakni SARS dan MERS yang berinang sekelomppok hewan, covid-19 menular dari satu orang ke orang lain begitu cepat. Virus ini menyerang tanpa melihat dia siapa dan di mana dengan menyerang manusia dengan berbagai gejala seperti pneumonia, gangguan sistem pernapasan hingga kematian. Virus corona merupakan bagian dari keluarga virus

2 Dian Adi Perdana lahir di Jakarta, 10 Juli 1993, penulis pherupakan Dosen IAIN Sultan Amai Gorontalo dalam bidang ilmu Manajemen, penulis menyelesaikan studi S1 Manajemen Dakwah Konsentrasi Manajemen Bisnis Islam dengan gelar Sarjana Sosial Islam di Universitas Islam Negeri Walisongo Semarang (2015), sedangkan gelar Magister Manajemen diselesaikan di Universitas Mercubuana Jakarta Program Studi Manajemen dengan Konsentrasi Marketing (2018). 
yang menyebabkan penyakit mulai dari flu hingga penyakit yang lebih berat seperti Middle East Respiratory Syndrome (MERS$\mathrm{CoV}$ ) and Severe Acute Respiratory Syndrome (SARS-CoV) (Nailul Mona, 2020 : 117). Kemenkes RI melaporkan bahwa pertama kali ditemukan kasus ini sebanyak dua kasus di Indonesia tepatnya pada 2 Maret 2020 (covid19.kemenkes.go.id).

Ditemukannya kasus covid-19 di Indonesia, telah memberikan batasan pergerakan massal diberbagai sektor seperti proses belajar mengajar dialihkan dengan menggunakan DARING (dalam jaringan) baik memanfaatkan aplikasi whatsapp, facebook, zoom meeting, jitsi meeting, google meet, dan sebagainya. Hal ini pun berdampak pada kegiatan sosial lainnya termasuk zakat fitrah di masa pandemik covid-19 ini. Ramadhan tahun ini lebih berbeda dari tahun-tahun sebelumnya, karena seluruh muslim terkena dampaknya dalam menjalankan segalah ibadah di bulan suci Ramadhan, salah satunya yakni menunaikan zakat fitrah. Anwar Abbas mengatakan pembayaran zakat fitrah dapat dibayarkan lebih cepat yakni di awal bulan suci Ramadhan. Pembayaran zakat fitrah kini telah memaksakan seluruh elemen masyarakat memanfaatkan perkembangan teknologi dan informasi melalui genggaman yakni gadget, computer maupun laptop yang dimiliki.

Beberapa terakhir, pembayaran zakat telah disinergikan dengan perkembangan teknologi yakni melalui perusahaan startup dan pendayagunaan financial techlology di Indonesia. Berbagai lembaga zakat gencar memasarkan produk zakat online untuk memberikan kemudahan kepada muzakki maupun pengguna layanan mereka. Promosi usaha dengan memanfaatkan sosial media dan smartphone yang dekat dengan genggaman masing-masing individu akan memberikan kemudahan tersendiri bagi penggunanya (Agustin dan Leon, 2019 : 2214). Berikut strategi pengelolaan zakat yang dilakukan

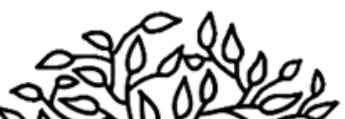


oleh lembaga-lembaga zakat melalui financial technology di Indonesia, yakni:

a) Badan Amin Zakat Nasional (Baznas)

Layanan digital telah dilakukan oleh Baznas sejak tahun 2016, hal ini dilakukan untuk memaksimalkan potensi zakat di masyarakat dengan memanfaatkan teknologi terbarukan dan menyongsong era revolusi industry 4.0. Kini baznas telah bekerjasama dengan berbagai perusahaan startup di Indonesia yakni digolongkan menjadi 3 kelompok.

1) Kelompok Social Media, yaitu Oy Indonesia dan Line (Zaki)

2) Kelompok E-Commerce, yaitu Mataharimall.com, Lazada.com, Blibli.com, Shopee.co.id, JD.id, Bukalapak.com, Tokopedia.com dan Elevania.co.id.

3) Kelompok Perbankan, yaitu Internet Banking, SMS Banking, EDC, E-Cash Mandiri, Doku Wallet, E-Pay BRI, Virtual Account dan T-Cash

4) Kelompok Apps atau fintech, yaitu OVO, Gopay, Kaskus, Gopoints, Kitabisa.com, Wisata Muslim, Oorth, MCash, TCash, Gotix, Invisee, Lenna dan Asuransi Jasindo Syariah (baznas.go.id).

b) Rumah Zakat (RZ)

Rumah Zakat merupakan lembaga zakat swasta tertua di Indonesia yang berpusat di Kota Bandung (rumahzakat.org), dengan berbagai program sosialnya, kini Rumah Zakat memberikan kemudahan bagi para muzakki untuk menzakatkan hartanya melalui layanan digital. Layanan digital diberikan oleh Rumah Zakat sejak tahun 2017 (bisnisjakarta.co.id). Berikut layanan digital yang diberikan Rumah Zakat:

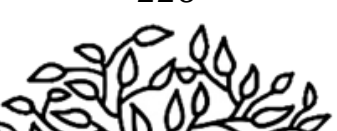


1) Layanan Digital, yakni Linkaja, OVO, Gopay Kaspro, Tokopedia.com, Lelangbintang.com, Infak ID, Doku, Bukalapak, Sharinghappiness.org dan Go Tix.

2) Layanan Perbankan, yakni SMS Banking, Internet Banking dan Transfer (Muamalat, BNI Syariah, Bank Mandiri, BCA, Maybank Syariah, BNI, BJB Syariah, BRI Syariah, BTN Syariah, Bukopin Syariah, CIMB Niaga Syariah, Danamon Syariah, Bank DKI Syariah, BSM, OCBC NISP Syariah, Mega Syariah, Permata Syariah dan BRI)

c) Dompet Dhuafa

Dompet Dhuafa merupakan lembaga nirlaba yang mengangkat harkat kemanusiaan terutama kaum dhuafa dengan dana ZISWAF. Lembaga ini bekerjasama dengan perusahaan startup dan financial technology sejak tahun 2019 (gomuslim.co.id), akan tetapi sebelum itu Dompet Dhuafa telah bekerjasama dengan perbankan baik secara kanal konvensional maupun digital pada tahun 2014 (zakat.or.id). Adapun pembayaraan zakat melalui layanan digital yang kini dapat dimanfaatkan oleh muzakki ialah:

1) Online Payment yakni Linkaja, DANA, CIMB Clicks, Tokopedia.com, IB Muamalat, OVO, ShopeePay dan Mastercar Visa

2) Transfer Bank yakni Virtual Account, Internet Banking dan SMS Banking (BNI, Mandiri, Muamalat, Maybank Syariah dan BCA)

d) Yayasan Dana Sosial Al-Falah (YDSF)

Yayasan Dana Sosial Al-Falah yang bisa kita singkat YDSF merupakan lembaga pendayagunaan dana ZISWAF yang beroperasi secara professional dan amanah. Lembaga ini berpusat di Surabaya, sehingga diawal pendiriannya lembaga ini lebih menaruh perhatian pada sektor sosial masyarakat Propinsi Jawa Timur. Lembaga yang telah berdiri

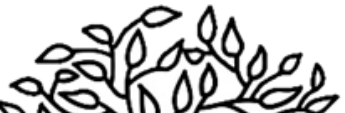


Strategi Pengelolaan Zakat Fitrah pada Masa Pandemic...

sejak 1987 ini telah bekerjasama dengan beberapa perusahaan financial technology di Indonesia pada tahun 2020 (ydsf.org). Adapun layanan digital yang telah digunakan oleh YDSF yakni:

1) Layanan Fintech yakni Gopay, GoMobile, OVO, DANA, Linkaja dan UANGTEMAN

2) Layanan Perbankan yakni SMS Banking, Internet Banking dan Transfer (Mandiri, BCA, Muamalat, BNI, BNI Syariah dan BSM)

Pembayaran zakat menggunakan fasilitas online telah menjalankan rukun-rukun zakat yakni adanya orang yang berzakat, harta yang dizakatkan, dan orang yang berhak menerima zakat (Amir, 2003 : 40). Mustahiq telah ditentukan oleh lembaga-lembaga zakat sesuai ketentuan yang termaktub dalam Al-Qur'an. Allah SWT berfirman dalam Q.S. AT-Taubah ayat 60 , tentang delapan golongan penerima zakat

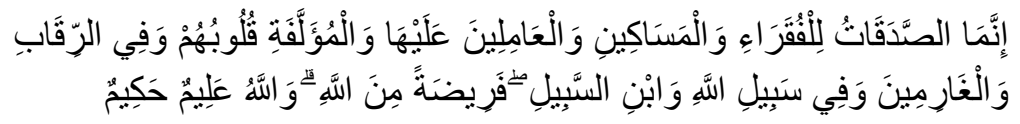

Artinya: "Sesungguhnya zakat-zakat itu, hanyalah untuk orangorang fakir, orang-orang miskin, amil zakat, yang dilunakan hatinya (mu'allaf), untuk (memerdekakan) hamba sahaya, orang-orang yang berhutang, untuk jalan Allah dan untuk mereka yang sedang dalam perjalanan, sebagai suatu ketetapan yang diwajibkan Allah, dan Allah Maha mengetahui lagi Maha Bijaksana".

Dalam buku karya Didin Hafidhudin syarat sah zakat yakni niat, karena sejatinya niat merupakan tujuan awal terjadinya suatu tindakan dan akan membedakan mana yang ibadah wajib dan sunnah (Didin, 2002 : 22). Syarat sah zakat selanjutnya yakni

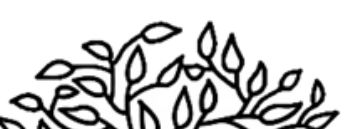


memindahkan kepemilikan harta kepada yang berhak menerimanya atau tamlik (Wahbah, 2010 : 117).

Syarat sah berzakat ada ijab qabul antara muzakki dan amil, serta amil dan mustahiq. Artinya setiap proses zakat tidak diwajibkan untuk saling bertemu, apalagi bersalaman dengan melihat kondisi pandemic covid-19 yang sesang melanda dunia ini. Lembaga zakat telah memberikan fasilitas berzakat secara online dengan berbagai ketentuan dan aturan yang telah diberikan, salah satunya yang dilakukan oleh Baznas yakni dengan tiga strategi pengelolaan zakat fitrah di masa pandemic yakni mengajak secara masif atau berkampanye untuk berzakat, melayani pembayaran dan membuka kanal donasi bekerjasama dengan beberapa financial technology. Strategi kampanye merupakan strategi paling ampuh di masa pandemik seperti ini, karena masyarakat akan lebih banyak memanfaatan teknologi dalam genggaman untuk segala aktifitasnya.

Menurut Rogers dan Storey dalam Venus, kampanye yang merupakan ajakan masif ialah rangkaian tindakan komunikasi yang terencana dengan tujuan menciptakan efek tertentu pada khalayak dalam jumlah yang besar, dilakukan secara berkelanjutan dalam kurun waktu tertentu (2004 : 7). Ajakan masih atau kampanye biasanya terorganisir oleh suatu lembaga dengan tujuan khalayak yang telah ditentukan (Arini, Tried dan Aat, 2019 : 71). Dengan ini strategi pengelolaan zakat fitrah dilakukan secara maksimal dengan berbagai perilaku pendukung yang telah terencana dengan baik, serta tidak terlepas dari implementasi fungsi-fungsi manajemen yakni POAC.

a) Planning dengan kerjasama dengan berbagai fintech dan $e$ commerce.

b) Organizing dengan menentukan tim IT yang handal dan tujuan massa.

c) Actuating dengan kampanye, akses kanal pembayaran dan pelayanan.

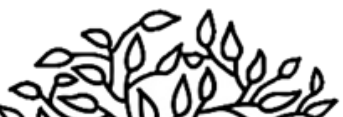


d) Controlling dengan pengawasan aktifitas zakat berdasarkan syariat.

Strategi dalam mengelola zakat bertujuan untuk mengetahui memperoleh informasi terkait dengan perilaku, pengetahuan, serta kesadaran masyarakat untuk menunaikan zakat fitrah. Sebagaimanakita ketahui, adanya praktik dan kebiasaan yang berubah karena imbas terjadinya pandemik covid-19 sehingga merubah perilaku dan kebiasaan masyarakat. Dengan adanya modernisasi sistem dalam berzakat akan memotivasi umat muslim untuk membantu sesame tanpa mengurangi norma agama yang telah diajarkan oleh Rasulullah SAW. Sebagaimana dalam sabdanya

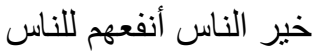

Artinya: "Sebaik-baiknya manusia ialah yang bermanfaat bagi orang lain". (H.R. Agmad dan Thabrani).

Keberadaan financial technology telah membuka dan membawa cakrawala lembaga zakat untuk selalu memanfaatkan teknologi informasi dalam setiap proses dan praktik operasional untuk memberdayakan zakat sebagai potensi pembangunan ekonomi sosial di Indonesia.

\section{DAFTAR PUSTAKA}

Antar, Venus. 2004. Manajemen Kampanye: Panduan Teoritis dan Praktis dalam Mengefektifkan Kampanye Komunikasi. Bandung: Simbiosa Rekaatam Media

Bulan Ramadhan, Dompet Dhuafa Sediakan Layanan Donasi Berbasis QR Code, https://zakat.or.id/bulan-ramadhandompet-dhuafa-sediakan-layanan-donasi-berbasis-qr-code/ dikutip pada 1 Juli 2020, Pukul 14.13 WITA.

Channel Pembayaran BAZNAS, https://baznas.go.id/id/channelpembayaran dikutip pada 30 Juni 2020, Pukul 18.51 WITA.

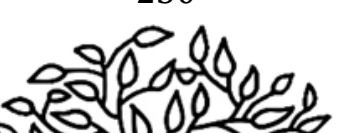


Damiarti, Arini Aprillia., Damayanti, Trie., Nugraha, Aat Ruchiat. 2019 Kampanye \#THINKBEFOREYOUSHARE oleh Organisasi Do Something Indonesia Untuk Mengubah Perilaku Generasi Milenial. Journal Of Communication Studies. Mar 1; 4(1): 65-94. Doi: 10.20527/mc.v4i1.

Gandeng E-Commerce Fintech, Dompet Dhuafa Kembangkan Sistem Digital Kelola Zakat, https://www.gomuslim.co.id/read/news/2019/05/17/122 83/-p-gandeng-e-commerce-fintech-dompet-dhuafakembangkan-sistem-digital-kelola-zakat-p-.html dikutip pada 1 Juli 2020, Pukul 13.44 WITA.

Hafhiduddin, Didin. 2002. Zakat dalam Perekonomian Modern. Jakarta: Gema Insani Press.

Infeksi Emerging Kemkes RI (2020) COVID-19. https://covid19.kemkes.go.id/category/situasi-infeksiemerging/info-corona-virus/\#.XwI71igzbIU diakses pada 30 Juni 2020, Pukul 09.57 WITA.

Mona, Nailul. 2020. Konsep Isolasi dalam Jaringan Sosial untuk Meminimalisasi Efek Contagious (Kasus Penyebaran Virus Corona di Indonesia). Jurnal Humaniora Terapan. Jun 1; 2(2): 117-125. Doi: 10.7454/jsht.v2i2.

Syarifuddin, Amir. 2003. Garis-Garis Besar Fiqh. Jakarta: Prenada Media.

Rumah Zakat dan Gojek Kerjasama Salurkan Donasi, https://duniafintech.com/rumah-zakat-go-jek-kerja-sama/ dikutip pada 1 Juli 2020, Pukul 10.46 WITA.

Rumah Zakat Hadirkan Dua Platform Startup, http://bisnisjakarta.co.id/2019/04/03/rumah-zakathadirkan-dua-platform-startup/ dikutip pada 1 Juli 2020, Pukul 11.51 WITA.

Sejarah Rumah Zakat, https://www.rumahzakat.org/tentangkami/sejarah/\# dikutip pada 30 Juni 2020, Pukul 20.33 WITA.

Trihandayani, Agustin., Abdillah, Leon Andretti. 2019. Analisis Penerimaan Pengguna dalam Memanfaatkan Media Sosial Terhadap Usaha Kecil Menengah Menggunakan Metode

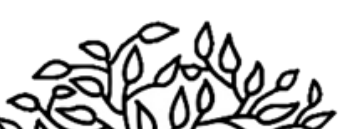


| Strategi Pengelolaan Zakat Fitrah pada Masa Pandemic...

Technology Acceptance Model (TAM). Bina Darma Conference on Computer Science. Jan 24; 1(6): 2214-2221. http://conference.binadarma.ac.id/index.php/BDCCS/articl e/view/473/412.

Yayasan Dana Sosial Al-Falah, https://ydsf.org/\# dikutip pada 1 Juli 2020, Pukul 14.22 WITA.

Zuhaily, Wahbah. 2010. Fiqih Imam Syafi'i. terj: M. Afifi, Abdul Hafiz. Jakarta: PT Niaga Swadaya 


\section{Kolaboragi Multidisiplin Ilmu}

dalam menghadapi Tantangan di Era New Normal

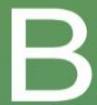

uku Bunga Rampai "Kolaborasi Multidisiplin IImu Dalam Menghadapi Tantangan di Era New Normal." merupakan karya anak bangsa, yang ditulis secara kolaboratif oleh para akademisi dari para praktisi bidang pendidikan nasional. Gagasan penulisan kolaboratif ini muncul saat terjadi Pandemi Covid-19, Tidak dapat dipungkiri bahwa COVID-19 membawa kita ke dalam era VUCA (volatility, uncertainty, complexity, ambiguity). VUCA adalah sebuah kondisi dimana terjadi perubahan cepat (Volatile) yang penuh ketidakpastian (Uncertainty), dengan segala permasalahan yang kompleks (Complexity), hingga pada akhirnya membuat semua pihak ragu mengambil keputusan (Ambiguity). Disaat semua akademisi dan praktisi menjalankan kegiatan sehari-hari dari rumah, muncul gagasan menerbitkan "tulisan bunga rampai" terkait situasi pandemi Covid-19 dan era New Normal serta situasi ke depan dalam menghadapi new normal. Kegamangan menghadapi situasi yang tidak menentu tersebut, menjadi ide dasar untuk dituangkan menjadi tulisan ilmiah populer.

Karya ini muncul disaat yang tepat, dimana saat pandemi Covid-19 para akademisi dan praktisi pendidikan memiliki banyak waktu untuk bekerja dari rumah, sehingga kesempatan yang ada mampu dimanfaatkan untuk bekerja lebih produktif dengan cara menulis. Semoga terbitnya buku ini dapat menjadi salah satu inspirasi bagi akademisi dan peneliti lainnya untuk terus menyoroti dampak COVID-19 dan dinamika yang terjadi di lapangan

Adi Wijayanto, Ridwan Balatif, Bakhrul Ulum, Nenni Dwi Aprianti Lubis,

Pasiska, Nur Saadah, Delsylia Tresnawaty Ufi, Mita Mahda Saputri,

Suwantoro, Angga Putra, Nurhayati, Nur Wahyuni, Aang Kunaifi,

Dedeh Afifah, Sri Wahyuni, Edwin Hutauruk, Faliqul Isbah, Dr. Kurroti A'yun,

Supriadi, Aris Priyanto, Azizah Husin,Merita Eka Rahmuniyati,

Muhammad Al Mansur, Nurul Huda, Siti Rodi'ah, Nurul Nitasari, Diana Lutfiana Ulfa, Dian Adi Perdana,

\section{Akademia Pustaka}

Perum. BMW Madani Kavling 16, Tulungagung

(@) redaksi.akademia.pustaka@gmail.com

(f)@redaksi.akademia.pustaka

(0)@akademiapustaka

081216178398

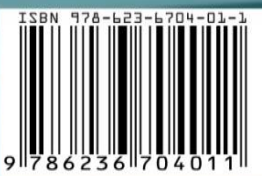

